UNIVERSIDADE DE SÃO PAULO

INSTITUTO DE GEOCIENCIAS

\title{
ESTUDO COMPARATIVO DE AMOSTRAGEM EM FUROS DE SONDAGEM E GALERIAS PARA PESQUISA DE CASSITERITA NO PEGMATITO XUPÉ - MONTE ALEGRE DE GOIÁS, GO.
}

Tarcísio José Montanheiro

Orientador: Prof. Dr. Jorge Kazuo Yamamoto

DISSERTAÇÃO DE MESTRADO

COMISSÃO JULGADORA

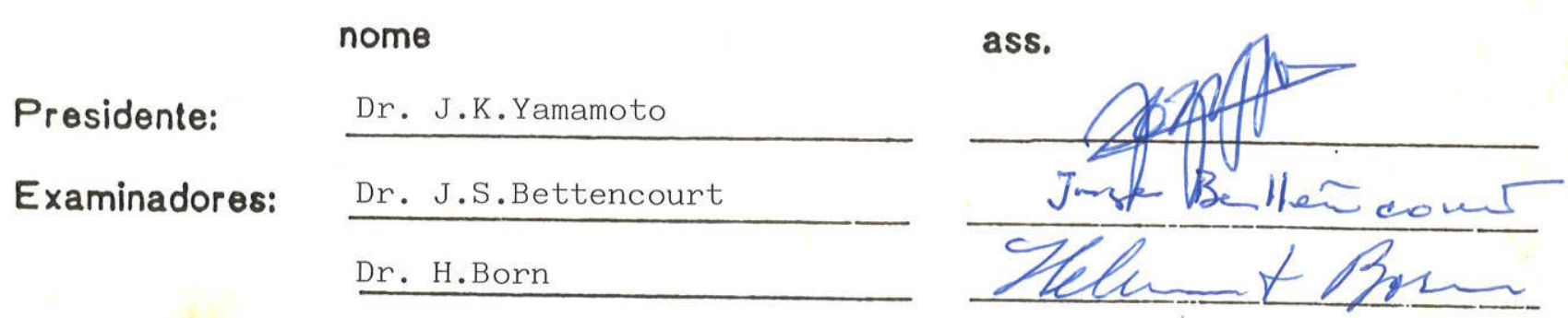

SÃO PAULO

1994 


\section{UNIVERSIDADE DE SÃO PAULO INSTITUTO DE GEOCIENCIAS}

\section{ESTUDO COMPARATIVO DE AMOSTRAGEM EM FUROS DE SONDAGEM E GALERIAS PARA PESQUISA DE CASSITERITA NO PEGMATITO XUPÉ - MONTE ALEGRE DE GOIÁS, GO.}

Tarcísio José Montanheiro

Orientador: Prof. Dr. Jorge Kazuo Yamamoto

\section{DISSERTAÇĀO DE MESTRADO}

Programa de Pós-Graduação em Recursos Minerais e Hidrogeologia

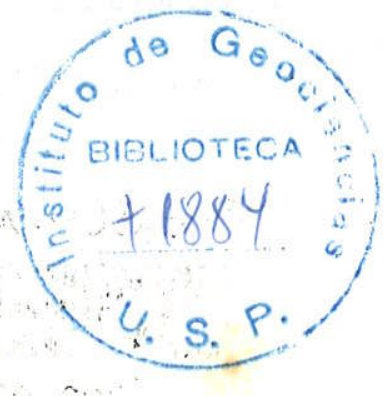

SÃO PAULO

1994 


\section{AGRADECIMENTOS}

Essa dissertação teve como base a nossa experiência e prática de campo ao longo de mais de dez anos dedicados às Empresas Brumadinho.

A elaboração final do texto que coroa os anos dessa experiência é uma parcela do nosso aprimoramento profissional e de formação científica. Durante toda essa fase recebemos o estímulo, a orientação e a colaboração de várias pessoas, instituições e empresas, às quais estendemos nossos sentimentos de gratidão, cuja profundidade nem sempre conseguimos pôr em palavras.

Dentre as pessoas cabe destacar o Prof. Dr. Jorge Kazuo Yamamoto que, em todo momento, esteve ao nosso lado, criticando, reformando, estimulando e orientando os caminhos para onde pretendíamos direcionar este trabalho.

Especial agradecimento ao Prof. Dr. Jorge Silva Bettencourt, co-responsável em primeira instância de nossa postura ética em todos os aspectos da formação pessoal e técnica no campo das geociências.

Ao Diretor das Empresas Brumadinho, engenheiro de minas Neuclayr Martins Pereira, por haver permitido a divulgação dos dados em que se fundamentou nossa pesquisa; ao Prof. Dr. Eduardo Camilher Damasceno, nosso coordenador da pesquisa de campo nessas Empresas; aos trabalhadores das frentes de pesquisa do setor de Monte Alegre de Goiás, em nome do geólogo Gilmar de Assis Pagotto, geradores dos dados de campo, nosso reconhecimento e gratidão.

Vale ressaltar a importância da CAPES - Coordenação e Aperfeiçoamento do Pessoal de Nível Superior - pela liberação de recursos financeiros.

Aos meus filhos e esposa, que, nesse tempo, foram sacrificados com nossa ausência e falta de atenção e carinho, nossas desculpas e especial reconhecimento.

Nossa gratidão se estende ainda à Telma, no desenho; ao Márcio e ao Leo, na digitação e formatação, à geóloga Rita, no tratamento estatístico e informatização, ao Jayme e ao Geraldo, estes nossos irmãos, no incentivo ao trabalho de leitura e organização do texto; e, por fim, ao Instituto de Geociências da USP, por ter colocado à nossa disposição todos os recursos técnicos e de pessoal. 


\section{SUMÁRIO}

pág.

\section{CAPÍtTULO 1}

INTRODUÇÂ̆O

1.1 Objetivos da dissertação $\quad 2$

1.2 Localização e acesso $\quad 3$

$\begin{array}{ll}1.3 \text { História geral } & 3\end{array}$

CAPÍTULO 2

ASPECTOS FISIOGRÁFICOS

2.1 Clima $\quad 7$

2.2 Geomorfologia $\quad 7$

2.3 Vegetação $\quad 8$

$\begin{array}{ll}2.4 \text { Drenagem } & 8\end{array}$

CAPÍtULLO 3

GEOLOGIA REGIONAL DE MONTE ALEGRE DE GOIÁS 9

3.1 Complexo granítico-gnáissico 12

$\begin{array}{ll}3.2 \text { Formação Ticunzal } & 15\end{array}$

3.3 Granitos diferenciados $\quad 16$

3.4 Granitos intrusivos do embasamento 16

$\begin{array}{ll}3.5 \text { Grupo Araí } & 17\end{array}$

$\begin{array}{ll}3.6 \text { Grupo Bambuí } & 18\end{array}$

$\begin{array}{ll}3.7 \text { Coberturas detrítico-lateríticas } & 18\end{array}$

$\begin{array}{ll}3.8 \text { Depósitos quaternários } & 18\end{array}$

CAPÍTULO 4

ASPECTOS DA GEOLOGIA DO DEPÓSITO XUPÉ 19

4.1 Os granitos diferenciados $\quad 19$

4.2 Os muscovita granitos (pegmatóides) 21

4.3 Filonitos (Formação Ticunzal)

4.4 Anfibolitos 21

4.5 Pegmatito Xupé $\quad 22$ 


\section{CAPÍTULO 5}

5.1 Objetivos e procedimentos da amostragem $\quad 27$

$\begin{array}{ll}5.2 \text { Finalidade da amostragem } & 28\end{array}$

$5.3 \mathrm{O}$ conceito de amostra $\quad 28$

5.4 Os componentes do problema amostragem 29

5.4.1 O componente geológico $\quad 29$

5.4.2 O componente químico 31

5.4.3 O componente físico $\quad 32$

5.4.3.1 A geometria e a posição dos corpos de minério 32

5.4.3.2 A qualidade do corpo de minério

5.4.3.3 Os processos de amostragem $\quad 33$

5.4.4 O componente estatístico $\quad 42$

5.4.4.1 O número de amostras $\quad 42$

5.4.4.2 Métodos de amostragem $\quad 42$

5.4.4.3 O conceito de viés e de variância do erro mínimo 43

5.4.4.4 O espaçamento entre amostras $\quad 46$

$\begin{array}{ll}5.5 \text { Preparação de amostras } & 48\end{array}$

5.6 Equação de amostragem de Gy $\quad 53$

$\begin{array}{ll}5.7 \text { Erros de amostragem } & 57\end{array}$

CAPÍTULO 6

INVENTÁRIO DOS DADOS DA PESQUISA MINERAL 61

$\begin{array}{ll}\text { 6.1 Densidade de informações } & 61\end{array}$

$\begin{array}{ll}6.2 \text { Exatidão da localização dos pontos de dados } & 71\end{array}$

6.3 Técnica de sondagem e recuperação média

6.4 Técnica de amostragem nos furos de sondagem 72

6.5 Técnicas de amostragem nas escavações subterrâneas 73

6.6 Preparação e análise das amostras dos furos de sondagem 75

6.7 Processamento em planta-piloto das amostras volumétricas e resultados analíticos 76

6.8 Determinação da densidade aparente ou fator tonelagem $\quad 78$

6.9 Recuperação da usina de beneficiamento $\quad 80$ 


\section{CAPÍTULO 7}

ESTATÍSTICA DOS DADOS DE AMOSTRAGEM 81

7.1 Distribuições de freqüências $\quad 82$

7.1.1 Representações gráficas de distribuições de freqüência 85

$\begin{array}{ll}7.2 \text { Parâmetros estatísticos } & 92\end{array}$

CAPÍTULO 8

REVISÃO DOS MÉTODOS CLÁSSICOS DE AVALIAÇÃO DE RESERVAS 96

CAPÍTULO 9

CÁlCULO DE RESERVAS DO PEGMATITO XUPÉ 109

9.1 Documentos básicos para cálculo das reservas 109

9.2 Critérios básicos indispensáveis para cálculo das reservas 109

CAPÍTULO 10

CONCLUSõES E CONSIDERAÇõES FINAIS 116

$\begin{array}{ll}\text { REFERÊNCIAS BIBLIOGRÁFICAS } & 118\end{array}$ 


\section{LISTA DE ILUSTRAÇÕES}

FIGURAS

pág.

1 - Mapa de localização, situação e vias de acesso

2 - Localização geotectônica dos granitos estaníferos de Goiás (Marini et alii, 1986)

3 - Subprovíncias e principais corpos graníticos da Província Estanífera de Goiás (Marini et alii, 1986)

4 - Esboço geológico e corpos de granitos estaníferos das Subprovíncias Tocantins e Paranã (Marini et alii, 1986)

5 - A Subprovíncia do Rio Paranã (Marini \& Botelho, 1986)

6 - Alinhamentos dos garimpos à cassiterita/tantalita em Monte Alegre de Goiás (equipe Brumadinho)

7 - Mapa geológico integrado de semidetalhe 1:7500

8 - Mapa geológico do Xupé, escala 1:1000

9 - Mapa geológico da galeria do Xupé, escala 1:100

10 - Amostragem por lascas: A - malha quadrada com lado paralelo à parede; B - malha paralela com lado paralelo ao contato; C - malha romboédrica (Kreiter, 1968)

11 - Exatidão e Precisão: A - A amostragem é enviesada e imprecisa (um dos casos mais freqüentes); B - A amostragem não é precisa. Não podemos dizer a amostragem é exata, visto que não há correlação entre $\mathrm{o}$ teor real da amostra e o teor real total; C - A amostragem é enviesada e precisa (seguindo leis desconhecidas); D - A amostragem é exata e precisa. (Pitard, 1992)

12 - Variograma. Exemplo de um modelo esférico adaptado para valores pontuais de um variograma experimental (Matheron 1963, apud Peters 1987)

13 - Representação esquemática da preparação de uma amostra. Cada ponto representa certa quantidade de material moído para determinado tamanho. A preparação de uma amostra é uma redução sucessiva de peso e tamanho dos grãos (David, 1988)

14 - Resumo dos estágios de amostragem aplicados num estudo de amostras de testemunho de sondagem (Jones, 1987) 
15 - Representação do método de amostragem por "cone e quarteamento" (Jones, 1987)

16 - Método de amosiragem do "ponto nove". Coletam-se oito porções em seguimentos já divididos; o nono ponto é coletado no centro (Jones, 1987)

17 - Subdivisor de amostra do tipo Jones (Jones, 1987)

18 - Esquema de subdivisão enviesada: é a forma comumente empregada, principalmente por falta de conhecimento (Yamamoto, 1993)

19 - Esquema de subdivisão correta, onde a porção quarteada apresenta o elemento com a mesma probabilidade do restante (Yamamoto, 1993)

20 - Planta esquemática das escavações subterrâneas na pesquisa do Pegmatito Xupé (equipe Brumadinho)

21 - Fluxograma da Planta-Piloto Xupé

22 - Gráfico da variação da densidade no Pegmatito Xupé

23 - Histograma das distribuições de freqüências de teores de estanho nos testemunhos das sondagens

24 - Curva acumulativa em escala de probabilidade aritmética da distribuição de teores de estanho nos testemunhos das sondagens

25 - Histograma logarítmico das distribuições de freqüências de estanho nos testemunhos de sondagem

26 - Curva acumulativa em papel de logprobabilidade aritmética para distribuição de estanho nos testemunhos das sondagens

27 - Histograma das distribuições de freqüências de teores de estanho nos avanços das galerias

28 - Curva acumulativa em escala de probabilidade aritmética da distribuição de teores de estanho nos avanços das galerias

29 - Histograma das distribuições de frequêencia logarítmica dos teores de estanho em avanços das galerias

30 - Curva acumulativa em escala de logprobabilidade aritmética dos teores de estanho dos avanços das galerias

31 - Histogramas das distribuições de freqüências dos teores de estanho nos testemunhos (A) e nos avanços das galerias (B) 
32 - Procedimento de cálculo de reservas pelo método dos blocos análogos (Popoff, 1966)

33 - Subdivisão em blocos, segundo suas características geológicas (Popoff, 1966)

34 - Subdivisão em blocos pelo método dos perfis padrão (Popoff, 1966) 99

35 - Subdivisão em blocos pelo método dos perfis lineares (Popoff, 1966).

36 - Método das isolinhas numa linha de pesquisa 10-10: "A", perfil de um corpo mineral; "B", planta de isópacas do mesmo corpo; "C", perfil construído a partir da planta de isópacas "B" (Popoff, 1966)

37 - Configurações de triângulos diferentes para um mesmo conjunto de dados, segundo Popoff (1966)

101

38 - A. "Triangulação de Delaynay" e B. "Divisão de Dirichlet", segundo Pettinati (1983)

39 - Desenho da seção S4 da Figura 34, ilustrando o procedimento de cálculo de área pela regra dos trapézios (Popoff, 1966)

40 - Método dos perfis padrão. A. fórmula da cunha; B. fórmula do cone (pirâmide); C. fórmula do tronco um cone. (Popoff, 1966)

41 - Método dos perfis padrão para cálculo do volume de seções não paralelas; "A" - é a representação gráfica de um corpo mineral interseptado por seções não paralelas; "B" - construção em planta das perpendiculares " $h 1$ " e " $h 2$ " a partir do centro de gravidade de uma seção para outra (Popoff, 1966) 


\section{QUADROS}

I - Aquisições de concentrados de cassiterita 6

II - Classificação dos depósitos minerais segundo sua variabilidade (Kreiter, 1968)

III - Reserva medida - Corpo I 112

IV - Reserva indicada - Corpo I 112

V - Reserva medida - Corpo II 113

VI - Reserva indicada - Corpo II 114

$\begin{array}{ll}\text { VII - Reserva medida geral } & 114\end{array}$

VIII - Reserva indicada geral 115

IX - Resumo da reserva total por corpos de minério 115 


\section{TABELAS}

1 - Número de fragmentos para composição de amostra conforme a variabilidade do depósito mineral (Kreiter, 1968)

2 - Dimensão da seção de canais retangulares (largura $\mathrm{x}$ profundidade em $\mathrm{cm}$ ), em função do grau de regularidade do corpo de minério (Kreiter, 1968)

3 - Valores do fator de liberação $l$, em função da razão entre o diâmetro da maior partícula na amostra (d) e o diâmetro de liberação (L) do minério (Ottley, 1966)

4 - Relação dos furos de sondagem na região do Xupé

62

5 - Resultados analíticos dos testemunhos de sondagem analisados no Depósito Xupé

62

6 - Resultados analíticos em $\mathrm{g} / \mathrm{m}^{3}$ de estanho e $\mathrm{Ta}_{2} \mathrm{O}_{5}$ dos avanços da galeria Xupé: $1=$ nome do avanço; 2 = intervalo de amostragem $(\mathrm{m}) ; 3$ $=$ volume da amostra $\left(\mathrm{m}^{3}\right) ; 4=$ volume acumulado $\left(\mathrm{m}^{3}\right) ; 5=$ teor de estanho do avanço ( $\mathrm{g}$ de $\left.\mathrm{Sn} / \mathrm{m}^{3}\right) ; 6=$ teor de estanho acumulado ( $\mathrm{g}$ de $\left.\mathrm{Sn} / \mathrm{m}^{3}\right) ; 7=$ teor de $\mathrm{Ta}_{2} \mathrm{O}_{5}$ do avanço $\left(\mathrm{g}\right.$ de $\left.\mathrm{Ta}_{2} \mathrm{O}_{5} / \mathrm{m}^{3}\right) ; 8=$ teor de $\mathrm{Ta}_{2} \mathrm{O}_{5}$ acumulado (g de $\mathrm{Ta}_{2} \mathrm{O}_{5} / \mathrm{m}^{3}$ )

68

7 - Distribuições de freqüências dos teores de estanho nos testemunhos de sondagem

8 - Distribuiçōes de freqüências dos logaritmos dos teores de estanho nos testemunhos de sondagem

9 - Distribuiçōes de freqüências dos teores de estanho nos avanços das galerias

10 - Distribuições de freqüências dos logaritmos dos teores de estanho nos avanços das galerias

11 - Parâmetros estatísticos das distribuições de frequiência dos dados de estanho nos furos e avanços 


\section{ANEXOS}

1 - Perfil Litológico A - A'.

2 - Perfil Litológico B - B'.

3 - Perfil Litológico C - C'.

4 - Perfil Litológico D - D'.

5 - Perfil Litológico E - E'.

6 - Perfil Litológico F - F'.

7 - Perfil Litológico G - G'.

8 - Perfil Litológico $\mathrm{H}$ - $\mathrm{H}^{\prime}$.

9 - Perfil Litológico I - I'.

10 - Perfil Litológico J - J'.

11 - Perfil Litológico K - K'. 


\begin{abstract}
This paper presents the results of a comparative statistic study between drill hole sampling and drift's channel sampling results carried out during the underground exploration and ore reserve evaluation in the Xupé pegmatite - Monte Alegre de Goiás - State of Goiás. The complete geological documentation available in the area, a revision of classical methods for ore reserve estimation and a revision of concepts and techniques of sampling are also presented in this dissertation.
\end{abstract}

The pegmatite ore bodies usually exhibit a large natural grade variability. In this way the sampling procedures are not easy to acomplish being of capital importance for the appropriate evaluation and industrial use as a source of rare metals.

When both drill hole and drift $\mathrm{Sn}$ grade results are compared, large differences of the average grade are noticed. This is true because of the inverse correlation between variance and sample volume which keeps the fundamental relation of sampling: volume $\mathrm{x}$ variance $=$ constant.

It is concluded that bulk sampling is most indicated for Sn pegmatite ore bodies evaluation and the grade values obtnined from drill cores should be used to delineate the tridimensional geometry and ore limits.

Measured and indicated reserves are of the order of $415000 \mathrm{~m}^{3}$, with $1695 \mathrm{~g} \mathrm{Sn} / \mathrm{m}^{3}$ and $53 \mathrm{~g} \mathrm{Ta}_{2} \mathrm{O}_{5} / \mathrm{m}^{3}$. 


\section{RESUMO}

Este trabalho, complementado por documentação geológica da região do depósito e por uma revisão não só dos métodos clássicos de avaliação de reservas como também dos conceitos e técnicas de amostragem na pesquisa mineral, apresenta os resultados de um estudo comparativo de amostragem em furos de sondagem e em galerias para pesquisa de cassiterita no Pegmatito Xupé, em Monte Alegre de Goiás, GO.

Os corpos pegmatíticos, por exibirem grande variabilidade natural dificultam os processos de amostragem e pesquisa, que, não obstante isso, são de vital importância, quando se pensa no aproveitamento industrial dessa fonte de vários metais raros.

Os estudos mostram existir grande diferença de teores médios de estanho nos furos de sondagem e em galeria: basta, para isso, observar a redução constante da variância em face da relação fundamental da amostragem: volume x variância.

Para corpos pegmatíticos constatou-se que a amostragem de grande massa é a mais indicada, e os resultados analíticos de furos de sondagem devem ser vistos apenas como valores indicativos, mas importantes, numa rápida visualização tridimensional do corpo mineral.

Com os dados levantados no inventário da pesquisa mineral, a avaliação de reservas do Pegmatito Xupé, pelo método dos perfis padrão, é da ordem de $415000 \mathrm{~m}^{3}$ de minério com 1695 $\mathrm{g}$ de $\mathrm{Sn} / \mathrm{m}^{3}$ e $53 \mathrm{~g}$ de $\mathrm{Ta}_{2} \mathrm{O}_{5} / \mathrm{m}^{3}$. 


\section{CAPÍtulo 1 \\ INTRODUÇÃO}

A importância do minério no desenvolvimento socioeconômico de uma região também foi notória na porção nordeste de Goiás, onde se fundou, entre outras, as atuais cidades de Arraias(TO), Monte Alegre de Goiás, Campos Belos, São Domingos, Cavalcante e Nova Roma, durante a corrida para o ouro, por volta de 1736.

Um segundo surto de desenvolvimento de caráter temporário ocorreu mais recentemente nessa região, nas décadas de 70 e 80 , devido à extração de cassiterita. Concorreu para isso, de modo marcante, a presença dos pegmatitos e granitos pegmatóides da Província Estanífera do Paranã como fonte de $\mathrm{Sn}, \mathrm{Nb} / \mathrm{Ta}$, na produção mineral do Estado de Goiás, que, entre os anos de 1977 e 1987, registrou 1136 t de concentrado de cassiterita (dados oficiais das Empresas Brumadinho, apenas para Monte Alegre de Goiás).

A partir de março de 1986, esse trepidante desenvolvimento veio a arrefecer com a crise mundial do estanho, seja pela queda no consumo do estanho, substituído por outros materiais, seja pelo aumento da oferta de Sn metálico, seja pela formação de estoques comerciais por parte dos produtores, consumidores, corretores e, mais efetivamente, do Estoque Regulador do Conselho Internacional do Estanho, seja, ainda, pelo surgimento de significativas reservas minerais de grande volume - algumas com teores elevados - mas de um tipo "capital-intensivo" (grandes investimentos, baixos custos).

Muito embora pegmatitos a metais raros, em particular, tenham sido, por um lado, o alvo de muitas pesquisas, nos últimos tempos, principalmente porque eles são uma fonte econômica para vários elementos metálicos e terras raras ( $\mathrm{Sn}, \mathrm{Ta}, \mathrm{Nb}, \mathrm{W}, \mathrm{Li}, \mathrm{Be}, \mathrm{Th}, \mathrm{La}, \mathrm{Y})$, e a diversidade mineralógica freqüentemente exótica tenha, por outro lado, atraído a atenção de mineradores e também de geólogos, a literatura geológica tem apresentado muita controvérsia sobre a origem dos granitóides e pegmatitos associados (Jahns, 1953; Page et alii, 1953; Kretz, 1968; Varlamoff, 1972; Cerny, 1982; Cerny e Meintzer, 1988). Porém, mais recentemente, Cerny (1991) apresentou uma revisão da classificação de pegmatitos graníticos relatando como um grupo de pesquisadores capacitados tem contribuído para o entendimento dos diferentes aspectos dos processos pegmatíticos. Nas principais linhas de investigação desenvolvidas durante os últimos anos, incluem-se estudos detalhados de campo, petrologia teórica e experimental complementada com mineralogia e petroquímica detalhada, isótopos e pesquisa de muitos pegmatitos virgens. Vêse, portanto, que os pegmatitos requerem um tratamento mais completo. Um potencial para extração simultânea de uma variedade de metais raros, com concentrações elevadas, e de minerais industriais faz, então, dos pegmatitos um alvo atrativo e de pesquisa muito complexa. Neste 
sentido, este trabalho procura enfatizar o problema da amostragem na pesquisa de pegmatitos, como um dos principais para fins de avaliação de reservas, principalmente, quando o depósito apresenta teores marginais, em função dos preços atuais do estanho. O Pegmatito Xupé, por enquadrar-se justamente nesta situação e a sua pesquisa ter sido realizada com critério, apresentá as condições ideais para um estudo desta natureza.

\subsection{Objetivos da dissertação}

Os estudos propostos neste trabalho têm como objetivo principal a comparação dos tipos de amostragem feitas no Pegmatito Xupé, com a utilização dos resultados analíticos de estanho em testemunhos de sondagem e amostras de galeria.

A exploração e pesquisa desse depósito foram desenvolvidas pelo Departamento de Pesquisa das Empresas Brumadinho, de cujas equipes de campo o autor participou a partir de 1979.

O termo "pegmatito" utilizado para a denominação Pegmatito Xupé é uma generalização de âmbito local para tipos de rochas pegmatítico -graniticas, na forma de uma lente subvertical, encaixadas em xistos e gnaisses graníticos da região.

As sondagens rotativas a diamante estão representadas por 15 furos de superficie com diâmetro NX ou BX. As galerias escavadas no nível $485 \mathrm{~m}$, aproximadamente 42 metros da superficie, são representadas nesse estudo somente pelo volume de material escavado dentro de rochas pegmatíticas e beneficiadas em uma Planta-Piloto. Os resultados comparados tanto nas amostras de testemunhos como nos avanços foram obtidos pelo método analítico de espectrografia óptica.

Para atingir os objetivos propostos, o trabalho será desenvolvido em etapas, na primeira das quais se apresenta a documentação geológica da região e do depósito, seguida de revisão dos conceitos e técnicas de amostragem na pesquisa mineral. A seguir faz-se um estudo dos resultados analíticos de estanho dos testemunhos de sondagem e amostras de galerias por análise estatística e umaavaliação comparativa entre os tipos de amostragem em furos de sonda e de galerias. Por fim este trabalho é rematado com uma revisão teórica dos métodos clássicos de avaliação de reservas e uma avaliação de reserva de estanho em pegmatito pelo método dos perfis padrão. 


\subsection{Localização e acesso}

A área do Depósito Xupé é parte de um trabalho de pesquisa geológica regional que abrange aproximadamente $620 \mathrm{~km}^{2}$ ao redor de Monte Alegre de Goiás, delimitados pelos meridianos $46^{\circ} 45^{\prime}$ e $47^{\circ} 15^{\prime}$, de longitude oeste, e pelos paralelos $13^{\circ} 05^{\prime}$ e $13^{\circ} 45^{\prime}$, de latitude sul. $O$ depósito propriamente dito situa-se na porção nordeste da área, às margens leste do Córrego Sucuri, cerca de $4 \mathrm{Km}$ a NE da sede do município (Figura 1).

O acesso à região se faz por Brasília, rodovia estadual GO-1 18, num percurso de $360 \mathrm{Km}$, atualmente asfaltada.

Uma pista de pouso, situada na extremidade sul do Depósito (proximidades do garimpo Xinguzinho), permite o acesso permamente de pequenas aeronaves à região, mas o acesso à área em estudo se faz por estradas e caminhos vicinais às fazendas e aos trabalhos de pesquisa.

\subsection{História Geral}

A área de $620 \mathrm{Km}^{2}$ prospectada pelas Empresas BRUMADINHO está situada na porção central da Subprovincia Estanifera do Rio Paranã, em terrenos da Província Estrutural Tocantins, a $300 \mathrm{~km}$ a nordeste de Brasília e nos arredores da cidade de Monte Alegre de Goiás, GO.

Em um projeto de inventário dos recursos minerais, patrocinado pelo Departamento Nacional da Produção Mineral, Barbosa et alii (1969) registraram as primeiras cassiteritas da região centro-oeste de Goiás, por meio de concentrado de bateia no córrego Sucuri, maciço Serra Branca, município de Cavalcante. A descoberta desse mineral na região de Monte Alegre de Goiás, por volta de 1973, deveu-se notadamente ao afluxo de garimpeiros a essas então recentes ocorrências. Tão logo correu a notícia da existência desses filões, importantes mineralizações estaníferas também se localizaram na porção sul da Serra Dourada (Região de Pela Ema e Mata Azul), na Serra Branca (município de Cavalcante e Minaçu), na Serra da Pedra Branca (município de Nova Roma) e em diversos pontos do município de Monte Alegre de Goiás.

A partir do momento em que empresas - notadamente DOCEGEO, CPRM, METAGO, TRICONTINENTAL e BRUMADINHO - se decidiram à pesquisa e lavra de cassiterita na região, esse ciclo de garimpagem começou também a interessar geólogos e mineradores que, ostensivamente, passaram a desenvolver trabalhos de pesquisa e a identificar, intensivamente, corpos aplíticos e pegmatíticos mineralizados a metais raros. 


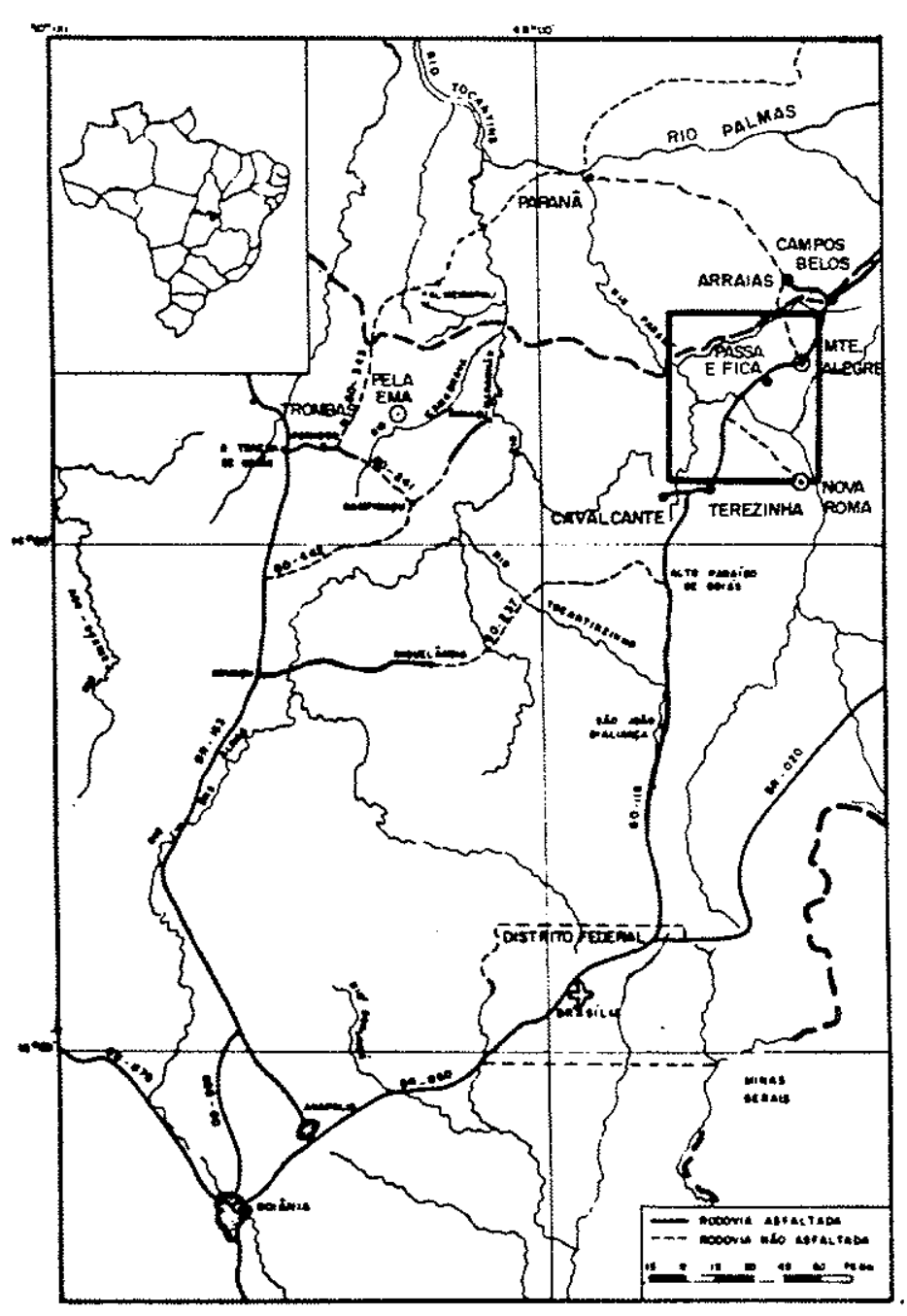

- Mopa de localização e acesso dos distritos mineiros de propriedade das Empresas Brumadintio com detalhe po-

ra a área pesquisada na porçāo

este de Goiós.

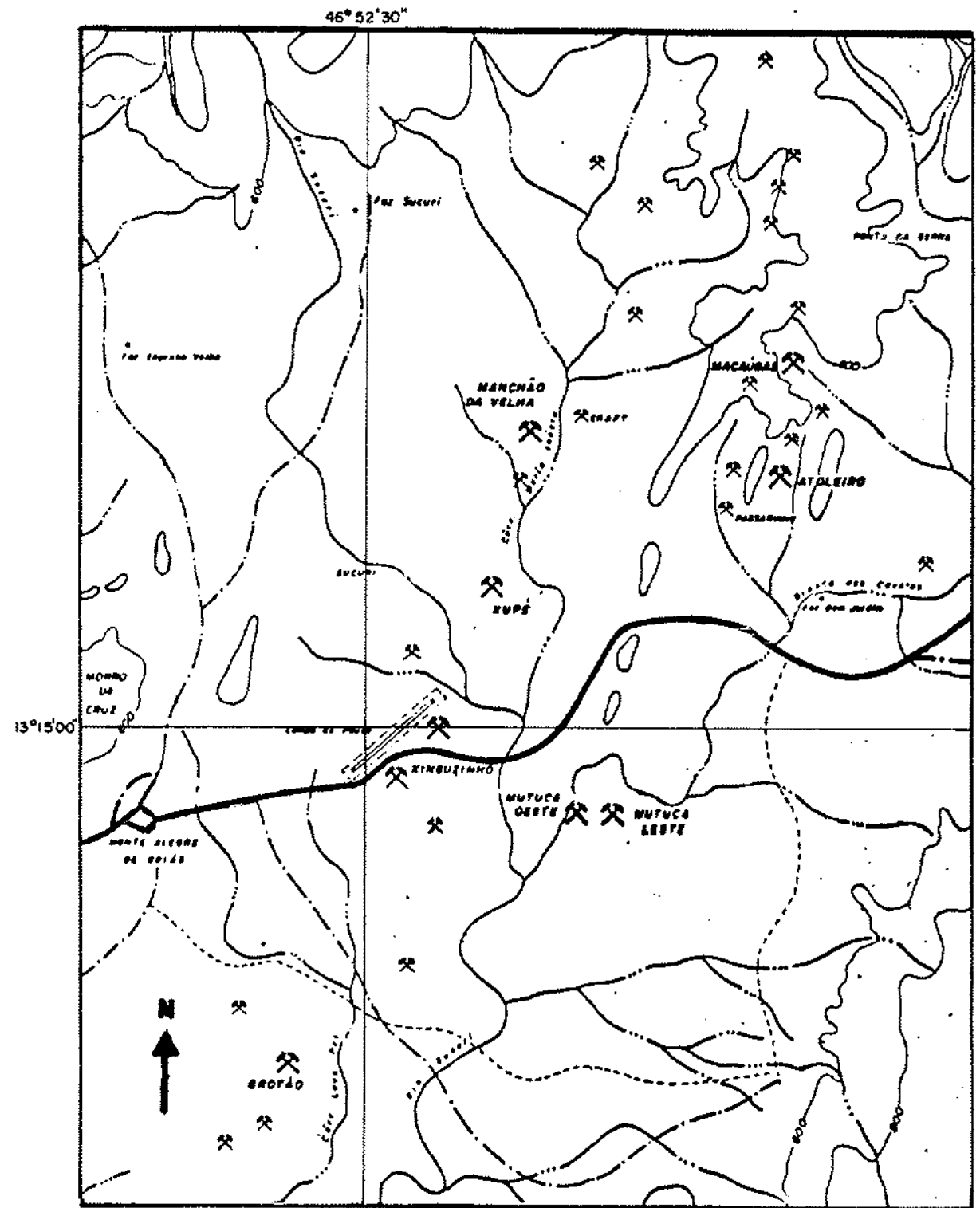

- Mopa de situaçōo do DEPÓSITO XUPÉ e das principois minerolizaçöes estaniferas e columbo-tantalífera da porço leste de Monte Alegre de Goiós. / ESCALA 1:75.000

FIGURA - 01 
Mesmo assim, à importância econômica adquirida por esses corpos contrapõe-se a relativa escassez de trabalhos com detalhes estruturais, mineralógicos e petrográficos da região. Botelho (1984), apresentou uma revisão desses trabalhos, a qual pode ser assim assim resumida:

- Araújo \& Alves (1979), no mapeamento regional do Projeto Canabrava Porto Real, fazem estudo comparativo dos granitos mineralizados da Província Estanífera do Centro-Oeste;

- Na Carta do Brasil ao Milionésimo, Schobbenhaus Fo et alii (1975 e 1976) fazem referências aos granitos das regiões dos rios Paranã e Tocantins;

- Fuck \& Marini (1978) apresentam um resumo sobre os granitos estaníferos das regiões dos rios Tocantins e Paranã;

- Padilha \& Laguna (1981) descrevem os granitos estaníferos da região do rio Paranã em seus aspectos estruturais, petrográficos e geoquímicos;

- Bettencourt et alii (1981) fazem citações resumidas sobre os principais garimpos portadores de cassiterita e tantalita da região de Monte Alegre de Goiás;

- No Projeto RadamBrasil (Folhas SD-21-Goiás e SD-23-Brasília) são feitas algumas referências aos granitos das Subprovíncias Tocantins e Paranã;

- Reis Neto (1983) apresenta a evolução tectônica da região dos granitos estaniferos de Goiás;

- Almeida Filho (1983) apresenta a aplicação de técnicas de sensoriamento remoto orbital na definição de áreas greisenizadas dentro dos maciços graníticos da Província Estanifera de Goiás;

- Marini et alii (1984) apresentam uma síntese sobre o conjunto de granitos estaníferos do centro-leste de Goiás, subdividindo-o nas subprovíncias ocidental e oriental;

- Botelho (1984) apresenta estudo petrográfico do granito Pedra Branca e as mineralizações de estanho associadas;

Outros estudos sobre a região foram publicados mais recentemente como:

- Damasceno (1988) apresenta uma revisão sobre a geologia do estanho no Brasil;

- Botelho et alii (1988) apresentam os controles e as principais mineralizações de estanho do Depósito Pedra Branca;

- Pagotto et alii (1990) apresentam um resumo dos pegmatitos a metais raros da região de Monte Alegre de Goiás.

No tocante à pesquisa e lavra conhecemos as executadas pelas Empresas BRUMADINHO, em princípios de 1981, e as da TRICONTINENTAL na mina CRAFT, um prolongamento para norte do Depósito Xupé. 
Desde meados de 1979, as Empresas BRLMADINHO tiveram presença marcante no Esstado de Goiás com as pesquisas geológicas, explotação e comercialização de cassiterita. $\mathrm{O}$ Quadro I mostra a quantidade de concentrado de cassiterita adquirido somente pelas empresas da Tricontinental (em 1981, a BRUMADINHO adquiriu as empresas Tricontinental) e FRUMADINHO no setor Monte Alegre de Goiás. Do total de $1136 \mathrm{t}$ de concentrado, $9 \%$ representam o Xupé, em contraposição aos 9,5\% do Pelotas; $28 \%$ do Riacho; $41 \%$ do Ingazeira; $6 \%$ do Arapuá e 6,5\% do Grotão. O corpo técnico das Empresas BRUMADINHO já pesquisou e lavrou parcialmente os depósitos Esperança (residual) e Buriti (em rocha dura) na região de Pela Ema (Figuras 1 e 4), depósito Passa-e-Fica (residual) em Monte Alegre (Figura 1 e 4) e depósito Grota Rica-Grota Seca em Nova Roma (Figura 1).

QUADRO 1

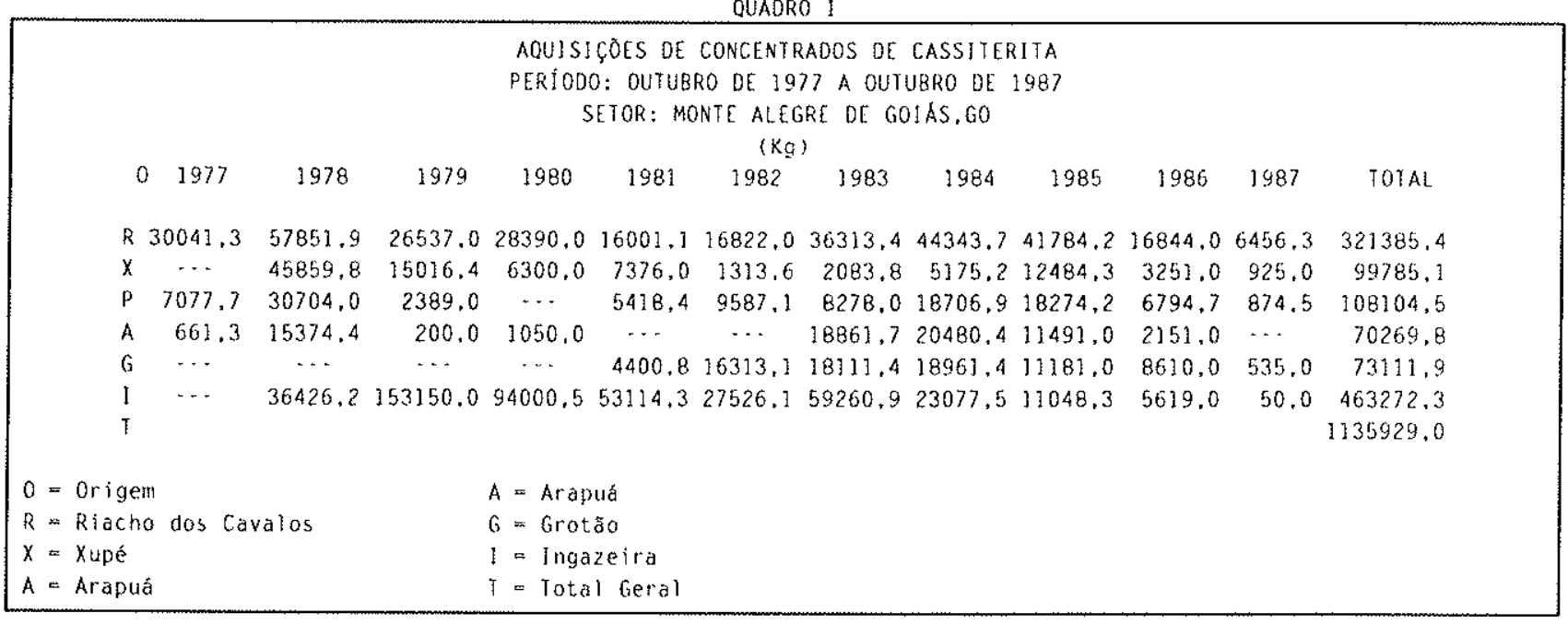

Tanto as jazidas Passa-e-Fica como Grota Rica-Grota Seca foram lavradas a céu aberto, por serem minas de encosta, em sedimentos detríticos elúvio-colúvio-aluvionares. As operações de lavra se processaram ora por desmonte hidráulico, ora por tratores de esteira, pá carregadeira e caminhões basculantes. A usina de beneficiamento, cuja capacidade nominal era de 20.000 $\mathrm{m}^{3} / \mathrm{mês}$ e teor de corte $350 \mathrm{~g} \mathrm{Sn} / \mathrm{m}^{3}$, se compunha do circuito convencional de jigues, complementado por dois estágios de concentração em espirais para a fração fina. Na operação de lavra da Mina Passa-e-Fica, ocorrida entre março/84 e dezembro/84, produziram-se 88 t $\mathrm{Sn}$ metálico e de $245.000 \mathrm{~m}^{3}$ de minério lavrado; na Mina Grota Rica-Grota Seca, que se deu de dezembro/84 até agosto/86, a produção foi de $176 \mathrm{t} \mathrm{Sn}$ metálico e $522.000 \mathrm{~m}^{3}$ de minério lavrado. Ambas as reservas já foram exauridas.

Estão semi-acabados os projetos de lavra em rocha dura nos depósitos Chapéu, Esperança, Buriti e Borda Sul na região do Pela Ema, Placha e Garimpinho (aluvião) na região de Nova Roma, Pelotas, Ingazeira, Xupé, Grotão, Mutuca-Leste, Mutuca-Oeste e Decreto na região de Monte Alegre de Goiás. 


\section{CAPÍtulo 2}

\section{ASPECTOS FISIOGRÁFICOS}

\subsection{Clima}

O clima da área de Monte Alegre de Goiás é característico da região central de Goiás e apresenta-se com dois períodos sazonais delimitados: um seco, que vai de abril a outubro, e outro úmido, de novembro a março. Na estação úmida, que corresponde ao período primavera/verão, ocorrem as chuvas torrenciais; na estação seca, que corresponde ao período outono/inverno, as precipitações inexistem ou são extremamente raras.

As temperaturas mais baixas ocorrem em junho, quando a precipitação é praticamente nula; as mais elevadas, no mês que antecede a época de chuvas, geralmente outubro.

$\mathrm{Na}$ região, o clima pode ser considerado quente e semi-árido a duas estações, enquadrando-se no tipo AW, da classificação de Koppen (RadamBrasil, 1982).

\subsection{Geomorfologia}

$\mathrm{Na}$ região de Monte Alegre de Goiás, ocorrem remanescentes que permitem identificar duas superficies de aplainamento. Uma, a mais elevada, com cotas em torno de $1.100 \mathrm{~m}$, está representada, na porção leste da área, pela Serra da Prata formada por quartzitos da Formação Arraias do Grupo Araí. Vestígios de antigos pediplanos (superficie pós-Gonduana de King) podem ser encontrados nas Serras de Araí e Traíras, a NW de Cavalcante. A segunda superficie possui cotas em torno de $500 \mathrm{~m}$ e está impressa na região sobre os gnaisses do Complexo Granito-Gnáissico (RADAMBRASIL, 1982).

"Essas duas superficies de aplainamento constituem feições geomorfológicas marcantes, que condicionam todo o quadro morfogenético regional. Nelas, os maciços graníticos apresentam-se como altos topográficos semicirculares com desniveis em torno de $500 \mathrm{~m}$ e bordas escarpadas. $\mathrm{O}$ topo dos maciços corresponde à superficie mais elevada, e o sopé de suas vertentes ao nivel de superficie de base. As serras, sustentadas pelos quartzitos do Grupo Arai, formam extensas chapadas no nivel ou pouco abaixo da Superficie Pratinha de Barbosa et alii, 1969 (Botelho, 1984)". Na área próxima ao depósito Xupé, as principais elevações correspondem às cristas alongadas da Serra do Passarinho e Tucano. 


\subsection{Vegetạ̣ão}

A vegetação em Monte Alegre de Goiás é representada por arbustos de pequeno a médio porte, esparsos, e por vegetação rasteira de gramíneas, que são característicos da região fitoecológica de cerrado que cobre a maior parte do centro-leste de Goiás. Além do cerrado também ocorrem campos e matas galeria; estas, formando capões em regiões de cabeceira, constituem a vegetação característica de algumas drenagens perenes.

Os campos se cobrem de gramíneas e subarbustos, predominantes nas regiões mais altas e aplainadas, e próprias de solos pobres.

O cerrado desenvolve-se principalmente nas encostas das elevações e nas ondulações, onde se apresenta mais denso. Em locais de solo mais rico, o cerrado transiciona para matas, formando capoeiras onde vicejam árvores de médio a grande porte.

\subsection{Drenagem}

Os rios da região fazem parte do sistema de afluentes da margem direita da Bacia Hidrográfica do Paranã, importante afluente da margem direita do Tocantins. A área Xupé é drenada pelos afluentes do Rio Sucuri o qual desemboca no Atalaia e este faz barra na margem direita do Paranã. 


\section{CAPÍTULO 3}

\section{GEOLOGIA REGIONAL DE MONTE ALEGRE DE GOIÁS}

Estudando granitos estaníferos da região centro-oeste do Estado de Goiás, Marini \& Botelho (1986) identificaram cerca de 20 corpos - agrupando-os em quatro Subprovíncias: Tocantins, Paranã, Ipameri e Pirenópolis-Goianésia, da Província dos Granitos Estaniferos de Goiás - os quais se situam na Província Estrutural Tocantins de Almeida et alii (1977).

Segundo esses autores, os corpos posicionam-se tectonicamente ou acham-se superpostos pelos metassedimentos internos e externos da Faixa Uruaçuana de idade Proterozóico Médio, conforme ilustrado pelas Figuras 2 e 3. Essa Faixa é, ainda, dividida (Fuck \& Marini 1981) litológica e estruturalmente pela Megainflexão dos Pirineus. Tais Figuras posicionam ao norte as Subprovíncias Tocantins e Paranã, ao passo que as Subprovíncias Pirenópolis-Goianésia e Ipameri se localizam na porção sul.

A Figura 4 mostra os corpos de granitos estaniferos e mineralizações associadas das Subprovíncias dos rios Tocantins e Paranã, as quais se destacam dentre as quatro, seja pela importância e variedade dos depósitos estaníferos, seja pelo número e tamanho dos corpos graníticos, seja, ainda, pelo estado de conhecimento que delas hoje se tem.

Os principais tipos de mineralização primária conhecidos nessas duas subprovíncias foram reconhecidos por Botelho et alii (1986) como:

a) albititos com cassiterita disseminada, nos granitos Serra Dourada - garimpos Cruzeiro (Mata Azul), Buriti (Pela Ema) - e Morro do Sucuri (Terezina-Go);

b) exogreisens (não definido) em quartzitos com wolframita, cassiterita e tantalita, nos granitos Serra Dourada - garimpo Tatu (Pela Ema);

c) endogreisens de fratura e de cúpula com cassiterita nos granitos Serra Dourada garimpo Areia (Pela Ema) -, Serra Branca, Morro da Mangabeira - garimpo Passa-eFica -, Pedra Branca (zona da Bacia, Placha e Monchão dos Baianos);

d) endogreisens de fratura com berilo no Granito Serra Branca;

e) exogreisens de fratura com cassiterita e sulfetos em granito-gnaisse e filonitos junto às bordas dos granitos Pedra Branca (borda sul) e Mocambo (garimpo Ingazeira);

f) pegmatitos com cassiterita, tantalita e wolframita no granito Serra da Mesa e nos pegmatitos da região de Monte Alegre de Goiás (Pelotas, Arapuá, Xupé, Alto Atoleiro) e São Domingos (garimpo do Córrego Bonito). 


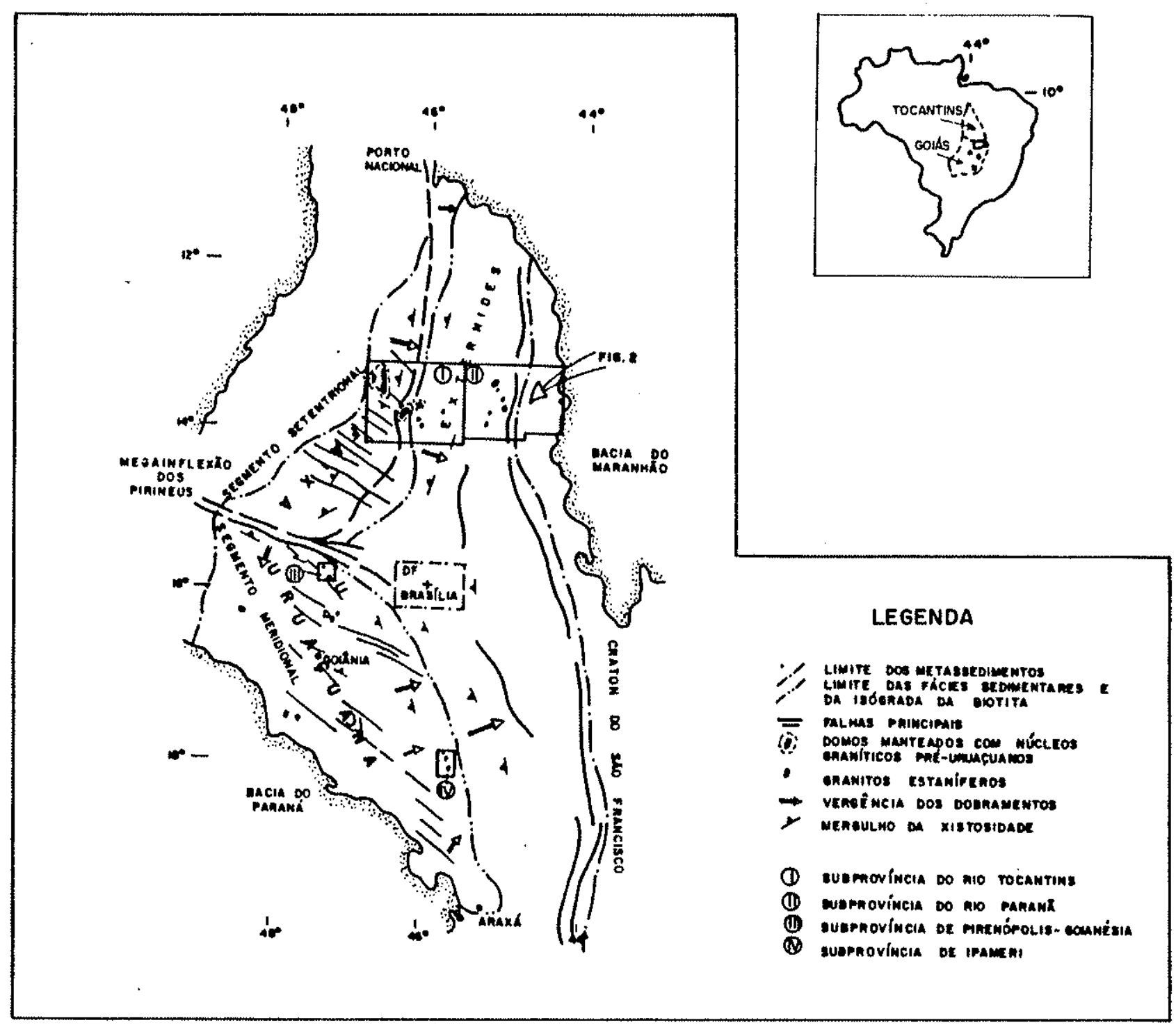

FIGURA 2 - LOCALIZAÇÃO GEOTECTÔNICA dOS GRANITOS ESTANÍFEROS DE GOIÁS (Segundo MARINI et alii, 1986) 


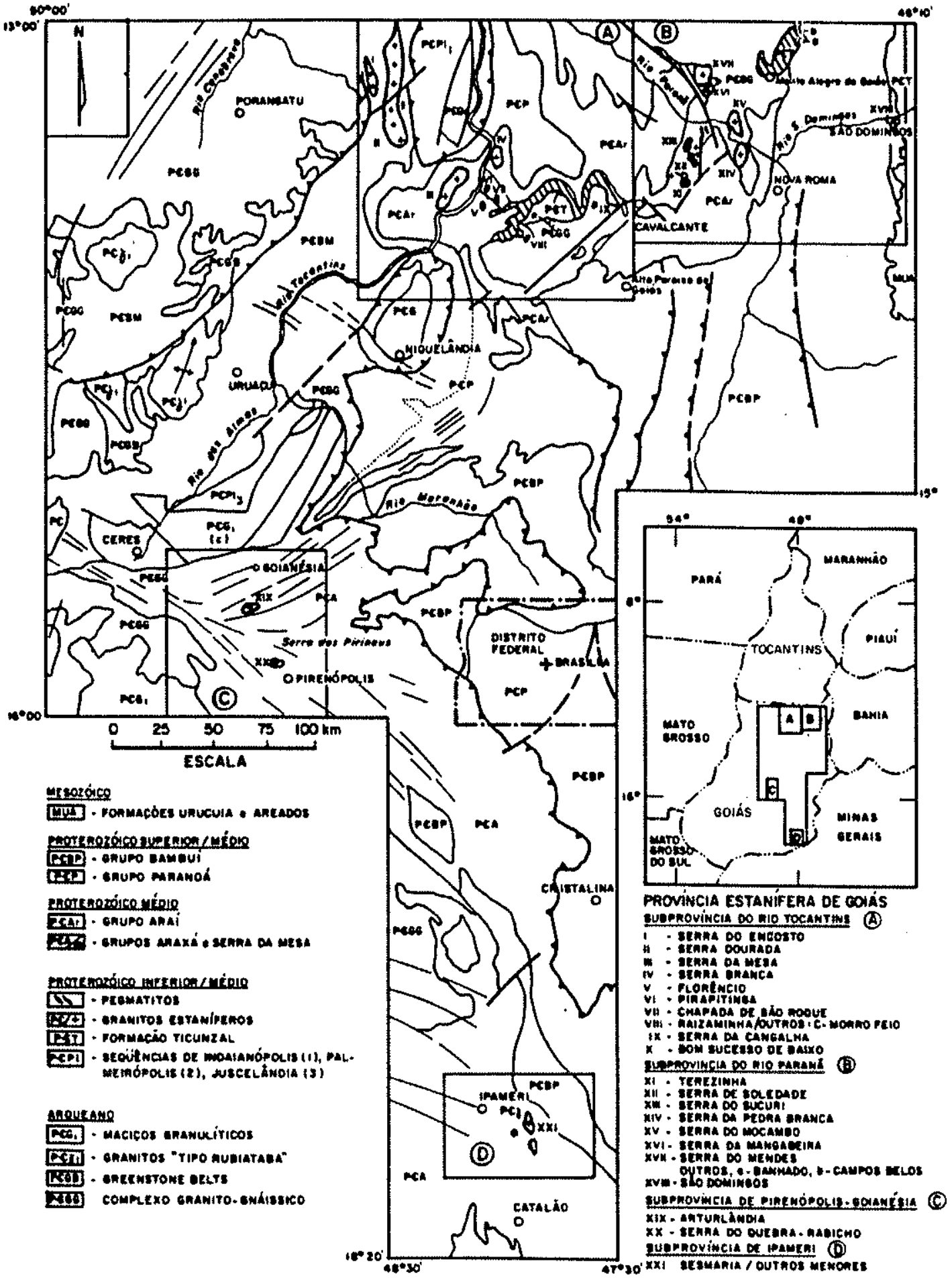

FIGURA - 3 SUBPROVINCIAS E PRINCIPAIS CORPOS GRANITICOS DA PROVINCIA ESTANIFERA DE GOIÁS (Segundo MARIN1, of alii, 1986). 
A região de Monte Alegre de Goiás insere-se no contexto geológico da Subprovíncia Estanífera do Rio Paranã. Nela ocorrem como unidades litoestratigráficas principais: o Complexo Granítico-Gnáissico, a Formação Ticunzal, o Grupo Araí e o Grupo Bambú. Alguns corpos graníticos subarredondados - Serra da Pedra Branca, no município de Nova Roma; Sucuri e Soledade em Terezina; Mocambo, Mendes/Mangabeira em Monte Alegre de Goiás - e pegmatitos associados a granitóides diferenciados ("granitos greisenizados" intrusivos em rochas do Complexo Granítico-Gnáissico e Formação Ticunzal) complementam o quadro geológico dessa Subprovíncia, conforme apresentado na Figura 5.

\subsection{Complexo Granítico-Gnáissico.}

As rochas granito-gnáissicas que compõem o substrato mais antigo da região foram reunidas por Almeida (1967) sob a denominação de Complexo Basal Goiano. Marini et alii (1984) agruparam essas rochas dominantemente arqueanas como Complexo Granítico-Gnáissico, onde se incluem: biotita-gnaisse, muscovita-gnaisse, hornblenda-gnaisse, gnaisses quartzo-feldspáticos, às vezes granatíferos, migmatitos e rochas cataclásticas (cataclasitos, milonitos e filonitos). As datações geocronológicas de Reis Neto (1983) indicam que a idade dessas rochas varia entre 3.200 e $2.500 \mathrm{Ma}$.

Individualizar tipos litológicos deste Complexo nem sempre é possível devido à carência de afloramentos ou à dificuldade em demarcar contato entre as unidades que, às vezes, é confuso ou gradacional.

Os gnaisses (biotita-gnaisses, muscovita-gnaisses, hornblenda-gnaisses, gnaisses quartzofeldspáticos) são rochas de cores esbranquiçadas, estrutura orientada e granulação fina a média. Ao microscópio eles exibem textura lepdoblástica e porfiroblástica ineqüigranular, com matriz da ordem de 0,4 mm e megacomponentes em torno de 1,5 a 3,0 mm. A composição mineralógica é quartzo, feldspato-K, muscovita e/ou biotita, hornblenda, plagioclásio e apatita. Os porfiroblastos de feldspato-K (microclínio) ocorrem em matriz, onde delgadas bandas de muscovita e/ou biotita irregulares se alternam com espessas bandas de quartzo-feldspato granoblásticos. Estas rochas exibem sinais de deformação.

Os migmatitos, normalmente associados a gnaisses mais homogêneos, de granulação milimétrica, geralmente são constituídos de paleossoma gnáissico e neossoma granítico (quartzofeldspático). As estruturas mais comuns na região são do tipo ptigmática, sheeliren, acamadadas, dobradas, e oftalmíticas. 


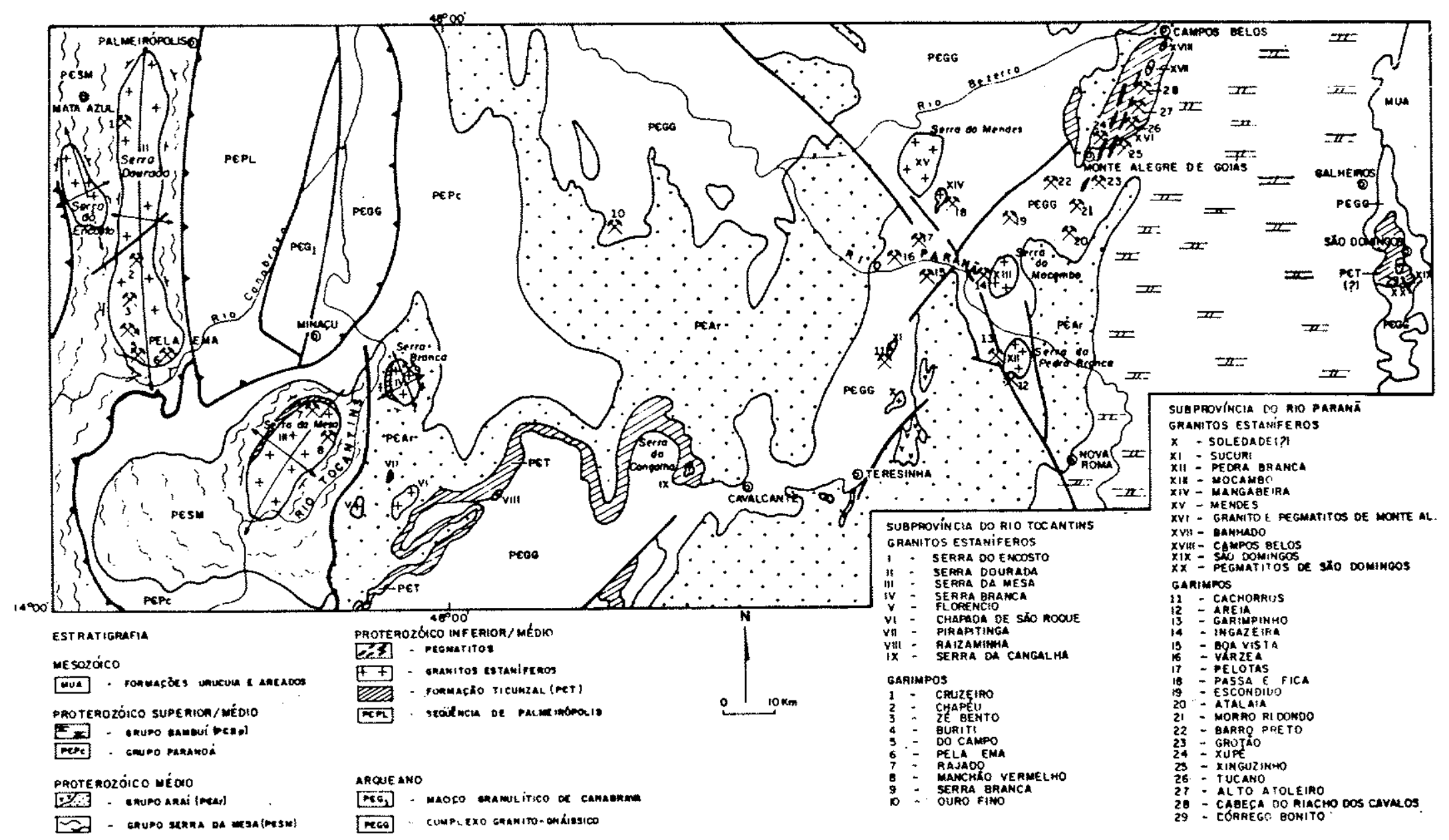

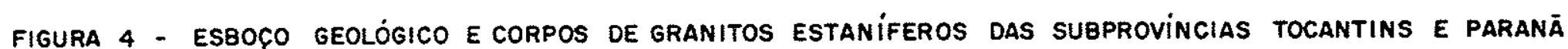




\section{A SUBPROVÍNCIA DO RIO PARANÄ}

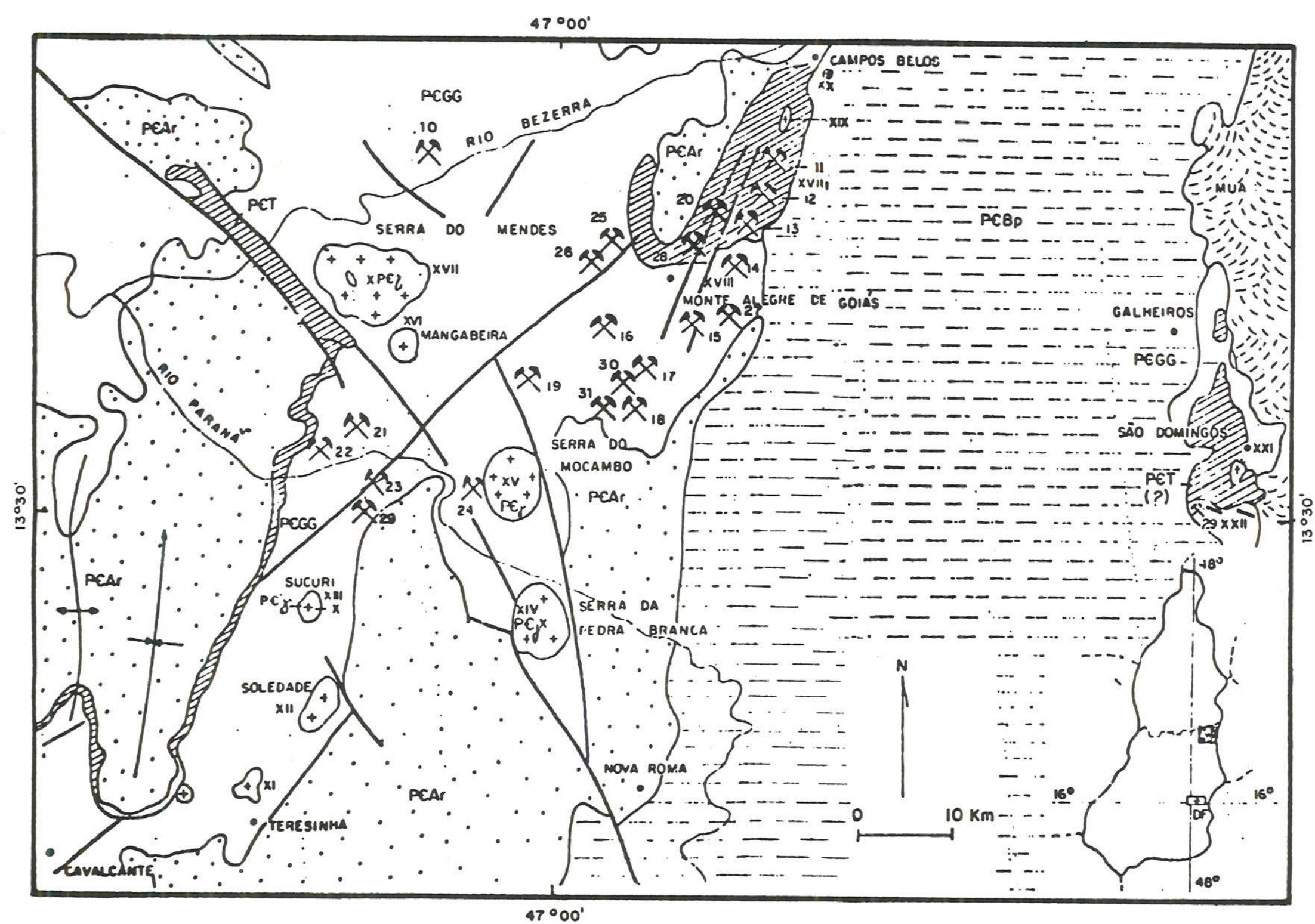

MESOZÓICO

É:-- MUA. FORM. URUCUIA IAREAOOS PROT. SUPERIOR

E-- PCBP-GRUPO BANBUI

PROT. MÉDIO

-. prar - grupo arai

$21 P_{0}$ - PEGMATITOS

++ t $P E_{j}$-granitos estanifERos PROT. INFERIOR

DDaret - FORM. TICUNZAL ARQLIEANO

[.] DEGG - COMPI. GRANITO - GNAISSICD GRANITOS ESTANIFEROS

$X I$ - TEREZINHA

$X I 1$ - SERRA DE SOLEDADE

XIII - SERRA DO SUCURI

XIV. SERRA DA PEDHA SRANCA

XV - SERRA DO MOCAMUO

XVI - SERRE SA MANGAAETAA

XVII. SLRRA DO MENDES

XVIII-PEGMATITOS/MIONTE ALEGRE

$X I X$ - BANHADO

$X X$ - CAMPOS BELOS

$X X I$ - SAOO DOMINGOS

XXII PEgMatitos DE SÁO DOMINGOS

\section{$x$ garimfos}

10 GezERRA

23 BOA VISTA

II CABEca do macho dos comalos 24 ingazeira

12. MIACHiO dos cavalos 25 barrocāo

1.3 Tucario

in XINGUZINMO

25 BARROCĀO

is GROTÄO

27 MUTUCA

I6 OARRO PRETO

17 MORRO KEDONCU

$28 X U P E$

18 atAlaila

29 BORRACHUDO

30 CAVEIRA

19 ESCONOIOD

3 I BACUPARI

20 MANCHĀO DA VELHA/ZÉ O'AREIA - 
A suíte cataclástica (catáclasito, milonitos e filonitos) resulta dos intensos esforços tectônicos a que foram submetidas as rochas gnáissicas anteriormente descritas. Os cataclasitos são rochas de coloração cinza-clara e granulação fina média; apresentam estrutura orientada que expõe deformação e alongamentos de cristas de quartzo e feldspatos, com a neoformação de sericita a partir destes últimos. Nas zonas de falhas, a deformaçăo é intensa e dá a essas rochas aspecto "xistoso". Via de regra originam um solo cinza-claro, de aspecto entre arenoso e arenoargiloso. Topograficamente ocupam as partes mais baixas do relevo. Por sua vez os milonitos e filonitos encontram-se, via de regra, laterizados em superficie; apresentam coloração avermelhada e estrutura xistosa, e dão origem a solos argilosos. São responsáveis pelas elevações colinosas sustentadas por veios de quartzo leitoso de diferentes espessuras. Quando pouco alterados por intemperismo, apresentam coloração cinza-clara e cinza-escura com minerais de quartzo e feldspatos $\mathrm{K}$ e Ca fortemente deformados e recristalizados. O desenvolvimento abundante de micas - sericita, principalmente, e clorita - deve-se a alterações sofridas pelos feldspatos e granadas, respectivamente, conferindo colorações escuras à rocha.

\subsection{Formação Ticunzal.}

É uma unidade que foi descrita por Marini et alii (1978) e definida como uma sequência de xistos com intercalações de paragnaisses. O seu posicionamento estratigráfico discorda do Complexo Granítico-Gnáissico e se sotopõe à Formação Arraias do Grupo Araí. A idade aproximada da Formação Ticunzal é $2.500 \mathrm{Ma}$. Os tipos litológicos mais comuns são biotitamuscovita xistos, em geral grafitosos, e paragnaisses. Outras variedades de xistos, porém subordinados, incluem tipos com granada, clorita e quiastolitas; diques de gabros e anfibolitos; corpos de aplito/pegmatitos e greisens mineralizados a $\mathrm{Sn}, \mathrm{Ta} / \mathrm{Nb}$, bem como veios de quartzo leitoso de diversas espessuras. Mineralizações auríferas e uraníferas foram localizadas nas zonas grafitosas, especialmente naquelas onde o controle estrutural (eixos de dobramentos) foi preponderante às concentrações.

Há minerais que parecem indicar condições elevadas de metamorfismo, como no caso dos plagioclásios (oligoclásio/andesina) e da granada, assim como alguns minerais que indicam metamorfismo de grau mais baixo, como a clorita, o epídoto e a sericita. Esses minerais de metamorfismo mais baixo, possivelmente do fácies xisto verde, podem estar associados ao fenômeno de cataclasamento e crenulação que afetou essas rochas.

A Formação Ticunzal distribui-se, mais freqüentemente, nas cercanias de Monte Alegre de Goiás. 


\subsection{Granitos Diferenciados.}

As litologias, aqui denominadas "granitos diferenciados", referem-se a rochas diferenciadas do Complexo Granítico-Gnáissico "que mostram evidências de esforços posteriores que çausaram fenômenos de cataclasamento e neoformação retratados pela recristalização do grão de quartzo, mascaramento das características do plagioclásio e, em menor proporção, microclinização dos ortoclásios existentes. Esse cataclasamento a que pode estar associado um evento tectonotermal foi de diferente intensidade e se refletiu de forma diferenciada nos diversos corpos, descritos ao microscópio por Reis Neto (1983) como de composição granodioritico e idade de $2500 \mathrm{Ma}$.

Apresentam-se como muscovita-granito, muscovita-biotita granitos, granitos pegmatóides quanto ao afloramento. De modo geral podem ser descritos como rocha de coloração cinza-clara a creme, granulação fina a média e, às vezes, grosseira, estrutura maciça, textura hipidiomórfica granular com quartzo (35\%), feldspato-K (21\%), plagioclásio-Ab (35\%), muscovita $(6 \%)$ e biotita (3\%). Os minerais acessórios compreendem os opacos, turmalina, apatita e fluorita.

A presença generalizada de muscovita nessas rochas parece relacionar-se à maior ou menor intensidade dos eventos pegmatíticos e hidrotermais ocorridos, os quais respondem pela muscovitização das encaixantes. Endoposicionados nessa litologia estão corpos aplitopegmatíticos e greisens mineralizados a $\mathrm{Sn}, \mathrm{Ta} / \mathrm{Nb}$, ao passo que, nas partes superiores dela, geralmente se posicionam corpos de quartzo leitoso de diversos tamanhos e, nas imediações desses corpos de quartzo, parece concentrar-se a tantalita-columbita, ao passo que a cassiterita ocupa as partes mais distantes, não obstante ter sido registrado, em diversos locais, um zoneamento mineral desta.

Em alguns pontos dessas faixas ainda ocorrem, sem expressão topográfica, pequenos corpos de muscovita granitos grosseiros, os quais têm sido descritos petrograficamente como granodioríticos no Grotão, adamelitos no Xupé e tonalitos nas proximidades ao Pelotas e maciço de São Domingos (ao norte).

\subsection{Granitos intrusivos do embasamento.}

Os granitos intrusivos em xistos grafitosos da Formação Ticunzal e/ou em gnaisses do Complexo Granítico-Gnáissico possuem formato semicircular, com diâmetro inferior a $15 \mathrm{~km}$, e se destacam no relevo mais suave das encaixantes. Eles constituem os maciços conhecidos como Serra do Mendes, Mangabeira, Mocambo, Sucuri, Soledade, Pedra Branca, entre outros. Esses corpos são representados, na maioria das vezes, por rochas do tipo biotita-granito granular, de 
fino a grosseiro, e atingem, mesmo, tipos porfiríticos com pouca ou nenhuma foliação. Internamente podem ocorrer zonas de muscovita granito-gnaissóide, com fluorita e greisens associados. São comuns rochas cataclásticas quartzo-micáceas, de cor cinza esverdeada e avermelhada, no contato com o Complexo Granítico-Gnáissico e em zonas de "stress" no interior dos granitos. Podem ocorrer diçues de granófiros de matriz fina e grãos maiores de fedspato-K $\mathrm{e}$ quartzo opalescente a biotita e/ou muscovita no interior ou nas bordas dos corpos graníticos.

O biotita-granito é a variedade litológica primária mais freqüente nesses corpos. Descrevese como rocha eqüigranular $(0,5$ a $3,0 \mathrm{~mm})$ com feldspato-K $(27 \%)$, quartzo $(26 \%)$, plagioclásio $(23 \%)$, biotita $(13 \%)$, epidoto $(8 \%)$, opacos $(1 \%)$, titanita $(2 \%)$, sendo a muscovita e a sericita os seus principais componentes secundários. Os feldspatos-K pertíticos formam, nesse granito, comumente, intercrescimentos gráficos, cujas feições ígneas são os plagioclásios idiomórficos a subidiomórficos e o quartzo corroído (rocha descrita do maciço Serra do Mendes), se bem que as porções cataclásticas na forma de bandas muscovita-granitos sejam suas feições comuns. Essas rochas possuem uma composição de feldspato-K, albita, quartzo, fluorita, muscovita, topázio e berilo, em cujo interior se encontram ainda veios de quartzo leitoso, pegmatitos, veios de quartzomuscovita, biotititos, veios albitíticos, zonas de fluorita disseminada que parecem representar o controle litológico das mineralizações de $\mathrm{Sn}, \mathrm{Ta}, \mathrm{Nb}, \mathrm{W}, \mathrm{F}, \mathrm{Y}$, e Be, além de sulfetos. Em alguns destes maciços já foram também descritos minerais como calcopiritas, arseno-piritas, pirita, esfalerita, bismutinita, bornita e azurita.

Botelho (1984) obteve uma isócrona indicativa de idade de $1.400 \mathrm{Ma}$ (Proterozóico Médio) para o Granito Pedra Branca.

\subsection{Grupo Araí.}

Este grupo foi definido por Dyer \& Meneguesso (in Barbosa et alii, 1969) que o dividiram em duas formações: a basal e a superior. A basal, Formação Arraias, é constituída por um espesso pacote de quartzitos médios a grosseiros, eventualmente arcosianos, com intercalações de metapelitos; nesse pacote também ocorrem níveis descontínuos de metaconglomerados e metavulcânicas de composição basalto-andesíticas onde se observa a predominância de dacitos e riodacitos, embora marcas de ondas e estratificação cruzada também sejam comuns. Rochas dessa unidade formam as serras da Prata, Roça Grande, Cubículo, Boqueirão, Contendas, Bom Jardim, Boa Vista, na região de Monte Alegre de Goiás. A formação superior - Formação Traíras - é a unidade, não descrita ainda na região de Monte Alegre de Goiás, que se constitui de quartzitos finos a grosseiros, metassiltitos, filitos, calcários e calcoxistos. 


\subsection{Grupo Bambuí.}

Nesta região, esse grupo é representado por rochas normalmente pelítico-carbonáticas: margas, ardósias, argilitos, quartzitos e conglomerado basal, da Formação Paraopeba de Braurı (1968). Na região de Monte Alegre de Goiás, este grupo se distribui a leste da Serra da Prata e,

daí até a Serra Geral, - arenitos da Formação Urucuia - na divisa entre os Estados de Goiás e Bahia.

\subsection{Coberturas detritico-lateríticas.}

Estas distribuem-se normalmente sobre as litologias da Formação Ticunzal e se constituem predominantemente de hidróxidos de $\mathrm{Fe}$ cimentando pastilhas do próprio xisto. Nas porções rebaixadas pelo relevo e próximo aos contrafortes das serras (talus) podem ocorrer extensas cascalheiras reconhecidas como restos da unidade Araí.

\subsection{Depósitos quaternários.}

Na região de Monte Alegre de Goiás, tais depósitos são inexpressivos devido ao caráter erosivo das drenagens, mas os de maior importância são os aluviões dos rios Paranã (nível base da região), Atalaia, Ribeirão dos Bois, Rio da Pedra, Areia, entre outros. 


\section{CAPÍt́tuLO 4}

\section{ASPECTOS DA GEOLOGIA DO DEPÓSITO XUPÉ}

Numa faixa norte-sul e a leste da cidade de Monte Alegre de Goiás, até os contrafortes da Serra da Prata (rochas do Grupo Araí), ocorrem rochas granitóides diferenciadas de idade arqueana e xistos da Formação Ticunzal.

Apesar de serem escassos os trabalhos de detalhamento estrutural, mineralógico e petrográfico, foram identificadas diferentes tipologias de natureza aplítico-pegmatítica e greisens com mineralizações de $\mathrm{Sn}, \mathrm{Ta}-\mathrm{Nb}, \mathrm{Be}$, quartzo, mica e caulim. Tais corpos, intrusivos em granitos diferenciados (Arqueano), muscovita granitos pegmatóides (idade indeterminada) e xistos da Formação Ticunzal (Proterozóico Inferior/Arqueano) se alojam preferencialmente no contato entre essas rochas e, em menor escala, no interior delas.

À luz dos conhecimentos atuais, esses corpos mineralizados preferencialmente a estanho são controlados estruturalmente por uma zona de cisalhamento alongada, regionalmente, numa direção N-NE. Os alinhamentos, conhecidos atualmente e ilustrados pela Figura 6 , formam três zonas principais de mineralização: "Trend" Xupé-Grotão, "Trend" Riacho dos Cavalos-Atalaia e "Trend" Morro Redondo-Mutuca.

As litologias, que compõem o quadro geológico local e cartografadas na Figura 7, se resumem em: granitos diferenciados, muscovita granito (pegmatóide), milonitos e filonitos, pegmatitos/aplitos e anfibolitos.

\subsection{Os granitos diferenciados}

Os granitos diferenciados do Xupé são rochas de coloração cinza-clara, estrutura maciça a levemente foliada, com textura entre média e grosseira e levemente cataclástica, compostas predominantemente por plagioclásio (34\%) muito salpicado de cristais de sericita e por cristais de quartzo $(34 \%)$ em agregados milimétricos orientados e recristalizados. Envolvendo os plagioclásios, ocorre ainda a microclina $(25 \%)$ como cristais pertíticos e, na proporção de $5 \%$, micas (muscovitas e sericita) em bandas ou ninhos milimétricos. Outros componentes como cloritas $(2 \%)$, opacos, titanita, zircão e apatita. 


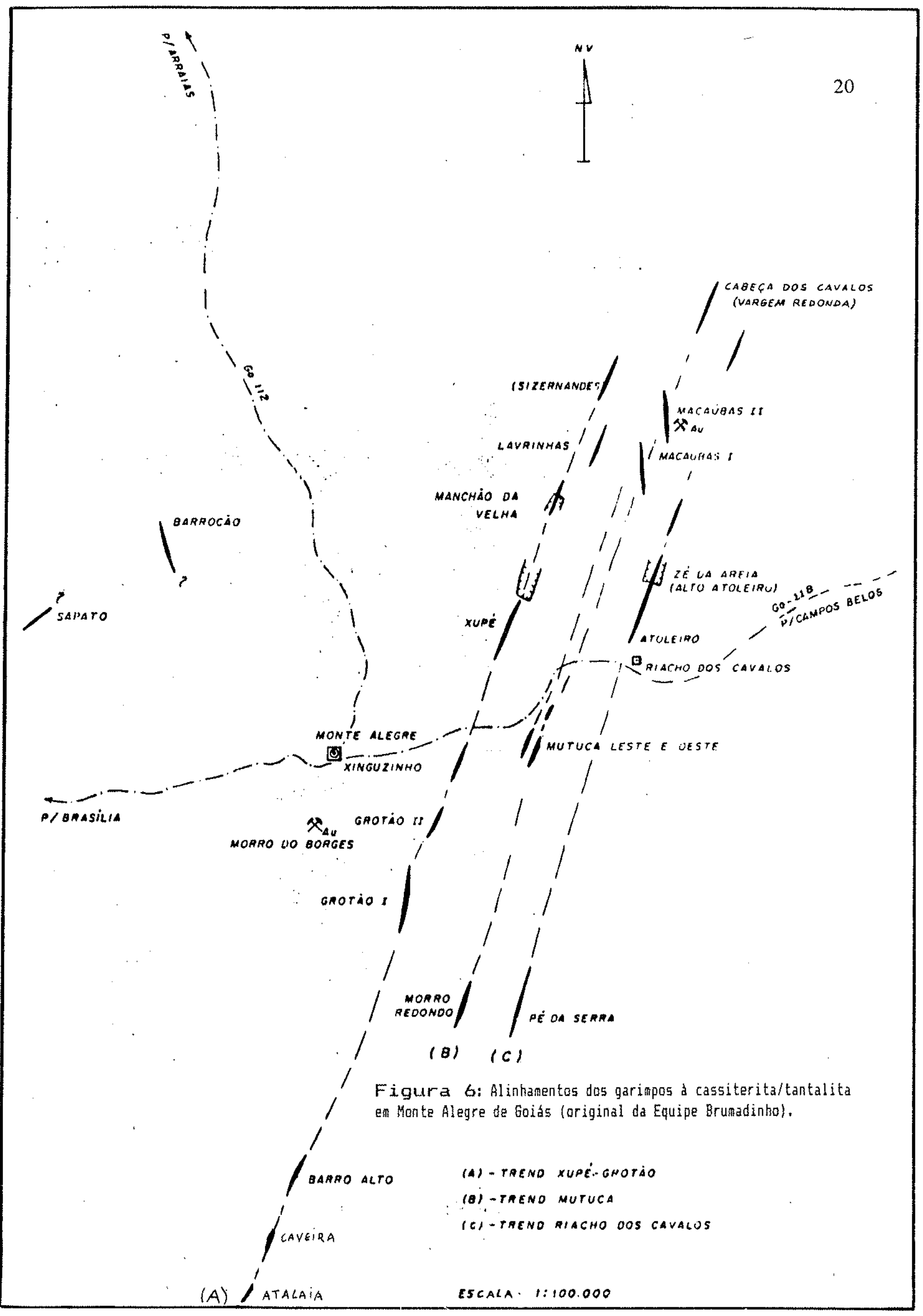




\subsection{Os muscovita granitos (pegmatóides).}

Os mussovita granitos (pegmatóides), que ocorrem como rocha de coloração clara, granulação média a grosseira, estrutura maciça e textura granular, afloram ao sul do pegmatito Xupé com uma composição média granítica: $40 \%$ de microclínio, $20 \%$ de plagioclásio, $30 \%$ de quartzo e $7 \%$ de muscovita. Outros minerais, como quartzo e plagioclásio (albita) parcialmente sericitizado, estão normalmente inclusos nos fenocristais de microclínio. Ainda podem ocorrer clorita, zircão, epídoto, biotita e, até, turmalina, disseminada em minúsculos grãos.

\subsection{Filonitos (Formação Ticunzal)}

Depois dos granitos diferenciados, os filonitos constituem os tipos litológicos mais comuns na área. Possuem granulação muito fina; são extremamente cisalhados, orientados, foliados, e contêm muita sericita. De coloração geralmente parda ou ocre, variam para tonalidades acinzentadas de acordo com a quantidade de grafita. Estas rochas ocorrem sob forma de faixas estreitas, sinuosas, alongadas predominantemente na direção nordeste, coincidentes com aquelas da foliação cataclástica, e, via de regra, os mergulhos são para NW.

No meio dessas faixas ou, às vezes, nas suas laterais, destacam-se bandas mais estreitas constituídas de lâminas pelíticas que se alternam com lâminas mais psamíticas pela presença de grafita. Nas proximidades do contato com o granito cataclástico, também é possível a presença de quiastolitas bem desenvolvidas. Podem ocorrer turmalinas pretas em outras zonas dos filonitos. Geralmente, nessas camadas extremamente plásticas, são comuns as crenulações e dobras, associadas ao efeito de arrastamento. Em vista dessas particularidades, há de se supor que os filonitos sejam realmente xistos cisalhados (Formação Ticunzal). Por vezes, é essa litologia recortada por veios de quartzo, paralelos ou discordantes da foliação cataclástica.

\subsection{Anfibolitos}

Estas rochas estão presentes nas proximidades do pegmatito do Xupé pelo lado oeste, formando espécie de diques na direção NNW, bem como em diversos locais da região de Monte Alegre de Goiás. Ao microscópio, essas rochas apresentam uma textura granoblástica, estrutura maciça com bandamento incipiente de anfibólio incolor e acicular (tremolita), comumente 
associado a epidoto. Os componentes, em menor propor ção, são cristais de clorita, se bem que, por vezes, como bandas menores, junto com algum quartzo aparecem plagioclásios do tipo albita.

\subsection{Pegmatito XUPÉ}

O pegmatito Xupé, que vem sendo garimpado desde 1974, é o maior corpo pegmatítico que se conhece na região de Monte Alegre de Goiás. Essa denominação é a que vem sendo utilizada indiscriminadamente nos trabalhos de garimpo, para identificar de modo geral os diversos tipos de pegmatitos graníticos na região.

O corpo pegmatítico - que se estende numa faixa de aproximadamente $2,5 \mathrm{Km}, 600 \mathrm{~m}$ dos quais economicamente aproveitáveis, até meados de 1985 - se configura especificamente mineralizado a cassiterita e columbita-tantalita, como minerais mais importantes. A mineralização está confirmada até $70 \mathrm{~m}$ de profundidade, com largura variável ao longo de seu comprimento entre valores máximos da ordem de $30 \mathrm{~m}$ na extremidade norte e menor que $1 \mathrm{~m}$ na extremidade meridional. $O$ corpo exibe morfologia variada, mas predominam o dique/sill e bolsões pegmatíticos; sua configuração ao longo dessa faixa mineralizada é de meia lua. Estruturalmente é controlado por uma zona de cisalhamento alongada regionalmente na direção N-NE. O caimento do corpo é variável entre 70 a $80^{\circ}$ para oeste, nas suas extremidades, e verticalizado na porção mediana.

O pegmatito é intrusivo tanto em granitóides diferenciados (adamelitos) como em filonitos da Formação Ticunzal, os quais se alojam, preferencialmente, no contato entre essas rochas e também com um muscovita granito ou, em menor escala, no interior dessas unidades, conforme apresentado nas Figuras 8 e 9.

A composição mineralógica deste pegmatito é essencialmente de quartzo, feldspatos, muscovita e montmorilonita. Como minerais acessórios ocorrem ainda cassiterita, columbitatantalita, magnetita, apatita, sulfetos (pirita, calcopirita), berilo, fluorita e espodumênio.

Duas associações mineralógicas típicas podem ser distinguidas no corpo: uma, predominante, constituída por feldspatos (caulinizados) e quartzo, e outra, menos comum, constituída essencialmente pela associação de quartzo e muscovita com granulação grosseira. Esta última associação dispõe-se, preferencialmente, no contato das encaixantes. Ainda, em meio à massa predominantemente pegmatítica, podem ocorrer aleatoriamente zonas e bolsões de aplitos. 
A cassiterita é conhecida ao longo do corpo com granulometria variável de fina a grossa. A associação quartzo-feldspática hospeda, via de regra, cassiteritas de granulometria mais fina, ao passo que a associação quartzo-muscovítica se associa às zonas mais enriquecidas desse óxido, onde os grãos do mineral atingem até $1,0 \mathrm{~cm}$ de diâmentro.

Sobre a tantalita ainda pouco se conhece quanto à sua distribuição e comportamento na área em estudo.

Apesar da falta de estudos refinados de natureza petroquímica, no que se refere à composição volumétrica - assembléia típica de elementos traços e tipos dos granitos associados com o Pegmatito Xupé - com os dados disponíveis pretende-se classificá-lo na família LCT dos pegmatitos de elementos raros, conforme proposto por Cerny, 1991. 


\section{CAPítulo 5}

\section{AMOSTRAGEM}

Baxter \& Parks (1939, apud Mckinstry, 1948) definem amostragem como "processo ou ato de selecionar uma amostra com características representativas de um todo". Esse processo compreende as etapas de coleta da amostra, o manuseio, a preparação, a determinação analítica seguida de interpretação dos resultados - e a avaliação final.

Durante o desenvolvimento de qualquer programa de pesquisa mineral - do reconhecimento às etapas de lavra, transformação e comercialização de um bem mineral - a amostragem é trabalho rotineiro de geólogos, engenheiros, metalurgistas e estudiosos das ciências da Terra. Da qualidade da amostra dependerá a confiabilidade dos resultados e o aproveitamento ou não do bem mineral. Assim sendo, reveste-se de vital importância esse processo, qualquer que seja sua finalidade. Por exemplo: para investigar a existência de minerais de valor econômico numa região faz-se amostragem geoquímica por sedimento de corrente durante a etapa de reconhecimento; para quantificar teores ou verificar o comportamento tridimensional de um corpo mineral, faz-se amostragem em trincheiras ou por testemunhos de sondagem ou trabalhos subterrâneos durante a etapa da pesquisa; para lavrar, beneficiar ou industrializar o bem mineral, os teores são controlados por amostragem.

\subsection{Objetivos e procedimentos da amostragem}

Quantas amostras seriam suficientes para um certo limite de confiança? Que tipo de método de seleção e avaliação de amostras adequada e suficientemente preciso e de menor custo possivel adotar? Para responder a estas questões, várias teorias sobre amostragem foram desenvolvidas e se criaram disciplinas de avaliação de dados.

"A Teoria da amostragem - Barnes, 1980 - se desenvolve em torno da idéia de que, se um número de unidades suficientemente representativas de uma população é selecionado sem enviesamento, o valor médio das unidades vai se aproximar ao da população total".

O objetivo da amostragem é avaliar o teor dos bens minerais para determinar:

a - os parâmetros geológicos fundamentais através do estudo da mineralogia e petrologia;

b - os parâmetros metálicos (p.ex. tonelagem, dimensões do corpo de minério, vida útil da jazida, etc); 
c - as características físicas para mineração e características de moagem; e,

d - o grau de precisão requerido no processo.

Em vista de serem práticos os trabalhos que constituem os processos de amostragem, a redução de erros depende de uma programação de amostragem apoiada nos seguintes procedimentos (Barnes, 1980):

- definição dos objetivos da investigação e da população (massa ou agregado de onde se coleta a amostra) a ser amostrada, por exemplo, o teor de determinada faixa de um corpo de minério zonado;

- determinação dos dados a serem coletados (os valores ou análises dependerão do tipo de depósito mineral em estudo);

- escolha da unidade de amostragem, representada, por exemplo, pelo tipo de amostragem (tamanho do canal ou intervalo de análise) e tamanho da amostra (peso ou volume);

- organização dos dados de campo (todos os dados e informações obtidos na coleta de amostras devem ser ordenados e registrados); $\mathrm{e}$

- economicidade do projeto de amostragem (estabelecer o balanço econômico do maior número de informações com o mínimo de erro e menor custo).

\subsection{Finalidade da amostragem}

Normalmente, as razões para a seleção de uma amostra são de ordem econômica redução de custos - e apresentam como vantagens principais (Cochran, 1953): maior rapidez, amplitude, flexibilidade e exatidão das informações, em face da impossibilidade de se registrarem integralmente as especificações do mineral que se propõe conhecer.

Por outro lado, o procedimento incorreto em uma das etapas da amostragem pode levar a resultados distorcidos que oneram, descaracterizam ou inviabilizam a pesquisa e o aproveitamento do bem mineral.

\subsection{O conceito de amostra}

A amostragem inicia-se com a coleta de amostras. $\mathrm{Na}$ impossibilidade de examinar minuciosamente toda a massa de qualquer volume de material em estudo, tomam-se dele pequenas porções - "amostras" - de acordo com os procedimentos conhecidos como 
"amostragem". Na literatura estatística bem como na geológica, todos os conceitos de amostra pressupõem que ela tenha ramanho pequeno e tipicalidade.

Barnes (1980) define amostra sob estes dois aspectos:

a - Definição estatística : ".... uma parte de uma população estatística cujas propriedades são estudadas para melhorar as informações sobre o todo";

b - Definição geológica : ".... uma parte representativa ou um simples item do todo, retirado deste ao acaso ou apresentado como prova de qualidade".

\subsection{Os componentes do problema amostragem}

O problema da amostragem pode ser melhor entendido quando estudado sob o aspecto dos seus componentes. Assim, segundo essa linha de estudo, pode-se encarar o problema de amostragem quanto aos componentes, geológico, químico, fisico e estatístico.

\subsubsection{O componente geológico}

A decisão inicial da amostragem diz respeito ao tipo de material geológico a ser amostrado. Para isso deve-se levar em consideração todas as informações geológicas disponíveis quanto ao planejamento do programa de amostragem:

a - litologia principal e horizontes litológicos: reconhecer e registrar o tipo de população (mineralógica ou litológica) e estabelecer os limites da amostragem são os passos mais importantes do processo, uma vez que os depósitos minerais raramente são homogêneos e devem ser delimitados por esses fatores. Com isso, as várias populações de amostras podem ser separadas, para se evitar a mistura e, conseqüentemente, resultados analíticos falsos;

b - sistemas macro e micro-estruturais: muitos depósitos minerais podem estar associados com falhas, fraturas e zonas de cisalhamento quando, então, as condições das rochas encaixantes podem interferir na diluição e no modo com que esses depósitos serão amostrados; igualmente, podem ocorrer minerais de interesse ao longo de microestruturas, tais como pequenas fraturas e filetes, que se estendem por todo o corpo de minério;

c - tipo de textura, tamanho dos grãos, conteúdo mineral e composição mineral são feições das características mineralógicas da rocha, que podem variar com frequência e influenciar no tamanho da amostra a ser coletada;

d - modo de ocorrência e a forma do depósito mineral possuem grande influência sobre o tipo e densidade da amostragem, assim como sobre a quantidade do material a ser coletado. 
Sob esse aspecto, Barnes (1980) e Annels (1991) reúnem as principais feições a serem consideradas em alguns grupos de depósitos minerais, tais como:

- depósitos porfiríticos de cobre e molibdênio: normalmente eles são depósitos extensos, de formato não tabular, com mineralizações disseminadas e baixo teor; requerem amostras de grande volume como as que podem ser obtidas por trincheiras, galerias e planos inclinados; o estilo e a intensidade de sua mineralização variam desde bolsões de sulfetos até veios ou fissuras; a existência de zonas oxidadas ou de alterações superficiais, zonas com enriquecimento supérgeno e zonas hipógenas devem ser reconhecidas pela amostragem;

- depósitos em veio são corpos tabulares, com mergulho normalmente forte, confinado entre paredes de rochas estéreis; os componentes (metálico/mineral) de valor estão distribuídos irregularmente através e dentro do plano do veio; o depósito mineral pode ser ligeiramente cristalino e requer uma amostra volumétrica para ser representativa; muitos veios são estreitos e conseqüentemente estão susceptíveis a diluição de minerais pesados; normalmente os veios são dificeis de amostrar devido à natureza quebradiça ou compacta dos seus constituintes sendo muito dificil evitar enviesamento; as variações na espessura são previsiveis e podem ser contornadas, ao passo que os teores são altamente erráticos e imprevisíveis, e por isso, requerem intervalo de amostragem fechado; muitos veios estão associados com falhas, fissuras e zonas de cisalhamento e as condições das encaixantes podem afetar a diluição, e portanto, no modo pelo qual eles são amostrados;

- depósitos "stratibound" são aqueles confinados a um horizonte estratigráfico favorável ou podem ser um depósito singenético formado durante a acumulação estratigráfica, a exemplo de depósitos a metal-base (Zambiam Copperbelt). Esses depósitos possuem uma grande extensão areal e tendência a ser espessos (p.ex., $20 \mathrm{~m}$ ); normalmente apresentam-se inclinados, fortemente dobrados e tectonizados, revelando problemas para amostragem e cálculo; os teores tendem a ser uniformes, exceto quando afetados por estágios posteriores de remobilização, metamorfismo ou por veios; muitos possuem teores relativamente elevados e, portanto, os erros de amostragem são menos significantes;

- depósitos sedimentares incluem os depósitos de potássio, gipso, carvão, ferro e depósitos de sal, caracterizados por contato brusco com as rochas encaixantes; variação gradual na indicação da qualidade (p.ex. teores);

- depósitos de ouro epitermal e em zona de cisalhamento apresentam alguns problemas especificos na amostragem, tais como: eles possuem formas geométricas irregulares a fracamente definidas; o teor do minério é dificil de ser definido; internamente eles são depósitos complexos, e as zonas de baixo teor ou de rocha hospedeira estéril resultam na diluição de pesados; 
Outros fatores que ainda poderiam irfîuenciar na amostragem são:

- mudança na suite mineral, p. ex., calcopirita e pirita para calcopirita e bornita;

- mudança na litologia da rocha hospedeira, p. ex., veio de quartzo para rochas alteradas, basalto para serpentinito, folhelho para quartzito;

- mudança no estilo de mineralização, p.ex., de minério maciço para disseminados ou em rosário tipos de rocha hospedeira.

\subsubsection{O componente químico.}

O geólogo que conhecer bem a composição química dos minerais poderá ter facilidade em identificá-los, e, por conseguinte, de acordo com a qualidade das propriedades deles, usá-los ou não para a indústria. No tocante às especificações químicas ou mineralógicas, o aproveitamento deles dependerá principalmente do progresso técnico a fim de tratá-los ou dar-lhes condições de uso imediato. Algumas vezes, importantes metais utilizados na indústria são descobertos em minerais de onde eles não podem ser extraidos economicamente com a tecnologia atual (p.ex. alumínio em argilas; antimônio, molibdênio e zinco em minério oxidado e outros). Outras vezes, "se, num minério de estanho, a associação mineral é cassiterita $\left(\mathrm{SnO}_{2}\right)$, o produto final terá boas perspectivas de ser de alto teor, isto é, de ser um concentrado com cerca de $75 \%$ de estanho; por outro lado, se ocorrer o mineral cilindrita $\left(\mathrm{Pb}_{3} \mathrm{Sn}_{3} \mathrm{Sb}_{2} \mathrm{Si}_{4}\right)$, é possível que o teor máximo do concentrado tenha $21 \%$ de estanho. Aliás, um concentrado rico em estanho sempre conterá $37 \%$ de chumbo. Esse tipo de concentrado estanho-chumbo não é de grande valor; é dificil negociá-lo com uma fundição porque a separação dos dois elementos por processos normais de fundição é trabalhoso" (Jones, 1987).

Por outro lado, o conhecimento detalhado da composição dos minerais pode explicar a perda incalculável de elementos valiosos em grande número de produtos formados durante as operações de tratamento mineral. Exemplo: piroxênio, mineral mais comum na ganga de alguns tipos de minério de cobre. Uma análise do piroxênio pode mostrar um conteúdo de cerca de $0,5 \%$ de cobre (cobre que não pode ser recuperado economicamente).

Outro exemplo da importância do componente químico está na amostragem de depósitos de areia utilizada na indústria do vidro. Existem zonas no minério muito ricas em minerais pesados e mica. Caso as análises químicas forneçam provas de teores elevados de $\mathrm{Fe}_{2} \mathrm{O}_{3}, \mathrm{Al}_{2} \mathrm{O}_{3}$, $\mathrm{TiO}_{2}$ e $\mathrm{K}_{2} \mathrm{O}$ (p.ex. maior que $0,1 \%$ de $\mathrm{Fe}_{2} \mathrm{O}_{3}$ total), esse material dificilmente terá aceitação como areia para vidro. 


\subsubsection{O componente físico}

Outro aspecto importante da amostragem diz respeito ao componente fisico. Aqui, incluise a determinação da forma e modo de ocorrência do corpo de minério no controle da mineralização; a definição do posicionamento quanto à direção e ao mergulho; a qualidade do minério; o processo de amostragem (visto que cada um fornece um tipo diferente de amostra) e a preparação e as análises químicas da amostra.

\subsubsection{A geometria e a posição dos corpos de minério}

O reconhecimento e a determinação da forma e extensão - da geometria - do corpo de minério em três dimensões são fatores importantes no processo amostragem assim como em relação à gênese ou na estimativa da reserva mineral.

A configuração dos corpos é, portanto, a principal variável que atua sobre os componentes geológicos da amostragem.

Quanto à geometria, os corpos de minério são classificados (Kreiter, 1968) dentro dos seguintes tipos morfológicos:

- eqüidimensionais: compreendem os corpos com dimensões mais ou menos iguais em todas as direções, tais como bolsões (p.ex. mineralizações sulfetadas e depósitos escarníticos); grandes "stockworks" (p.ex. depósitos de cassiterita, de crisotila e cobre porfirítico); e, na forma de colméia (p.ex. depósitos de domos salinos e corpos metassomáticos hidrotermais);

- tabulares: incluem corpos com uma dimensão pequena e duas dimensões maiores. Nesses tipos podem incluir-se veios ou filões, camadas, lentes, diques, "sills" e outros;

- alongados: incluem corpos com uma dimensão maior que outras duas tais como "pipe" e corpos com formas semelhantes.

Para aqueles corpos de minério cuja forma não se enquadra nos tipos convencionais apresentados, Jensen \& Bateman (1979) agruparam-os como tipo inconstante. Eles possuem formas complexas ou uma combinação de formas em vista das condições de sua origem. Nesses podem-se enquadrar, por exemplo, corpos originados por preenchimento de brechas ou de cavidades de dissolução e corpos oriundos de processos metassomáticos.

Outro impacto considerável na amostragem, ainda associado à geometria, é a definição do posicionamento dos corpos em termos de direção e mergulho. Do mesmo modo como podem ocorrer aumento de volume ou concentração de minerais ao longo das feições morfológicas do 
corpo de minério, esse relacionamento também pode estar associado às mudanças ou variaçães registradas a determinado rumo e caimento do mesmo.

\subsubsection{A qualidade do corpo de minério}

Entendem-se como qualidade de um minério os atributos que o tornam aproveitável na indústria. Dentre várias propriedades que condicionam a qualidade incluem-se a densidade, a granulometria, a dureza, a ductilidade, a elasticidade, a resistência à erosão e outras. Normalmente, os atributos mais importantes e definidores da qualidade são o conteúdo metálico (teor) e o tamanho ou volume do corpo de minério. No caso de minerais não metálicos o tamanho não dependerá propriamente do teor mas do preço da concentração.

\subsubsection{Os processos de amostragem}

Durante as fases de realização da pesquisa mineral existem vários tipos de trabalho e de técnicas utilizados para a seleção de amostras. Esses diferentes processos de amostragem desenvolveram-se a partir da experiência de profissionais da área durante a coleta de inúmeras amostras.

"Em alguma das fases de pesquisa e com alguns tipos de depósitos minerais, certos procedimentos tornaram-se padronizados e dão resultados exatos. Desta maneira, desde que um procedimento tenha sido desenvolvido para certo tipo de depósito ou minério, um profissional deverá acompanhá-lo do começo ao fim, a menos que outro método alternativo seja mais exato" (Parks 1949 apud Barnes, 1980).

Na literatura existente sobre amostragem - Taggart (1945), Mckingstry (1948), Peele (1960),Kreiter (1968), Peters (1978), Barnes (1980) e Annels (1991) - esse assunto tem sido estudado relativamente às operações executadas a superficie e em subsuperficie.

Kreiter (1968), no capítulo "Amostragem em trabalhos subterrâneos", englobou os tipos de amostragem em três grupos: pontual, linear e volumétrica. $O$ primeiro grupo compreende métodos de amostragem de poço, catação e amostra "de mão"; o segundo compreende amostragem de canal e furos de mina; e o terceiro a amostragem volumétrica e de face.

Os principais tipos de amostragem são:

a - Amostras "de Mão". Constituem o tipo mais simples da coleta de uma amostra. Apesar de elas não serem representativas de uma população, é aconselhável coletar amostras de rocha de várias unidades geológicas para uma análise regional. Numa avaliação preliminar da 
assembléia mineral, esses resultados podem direcionar um programa de amosiragem das etapas de pesquisa. O conteúdo metálico dessas amostras de rocha é indicativo do "background" das unidades amostradas.

b - Amostragem por Lascas ("Lump and chip sampling"). Sobre um lençol plástico ou lona, colhem-se pequenos fragmentos ou lascas de rocha do mesmo tamanho, ponteadas a marreta, pontaletes ou pontaletes pneumáticos, numa faixa, por exemplo, de aproximadamente 10 a $30 \mathrm{~cm}$ de largura e poucos milimetros de profundidade, pelas faces expostas do minério. Apesar de ser feita com muito cuidado, existe grande possibilidade, intencional ou não, de se variar o tamanho dos fragmentos ou de se sobreporem pontos já amostrados, principalmente em bolsões ou zonas mais ricas em minério do que em outras (mais pobres).

Outra alternativa para amostragem por lascas é pontear toda a face de interesse sobre os nós de uma malha imaginária de forma quadrática a romboédrica e, com isso, reduzir o enviesamento da coleta de amostras. Amostras de lascas é um tipo de amostragem utilizado para controlar o teor de produção das minas, definir as faixas de corte das frentes, reencontrar o minério, selecionar e classificar reservas em bancadas.

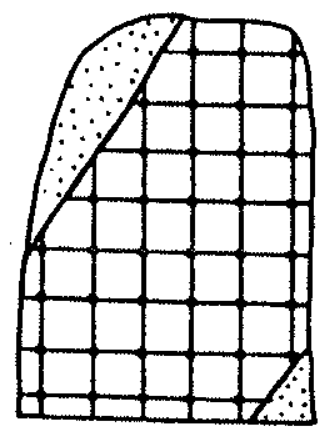

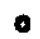

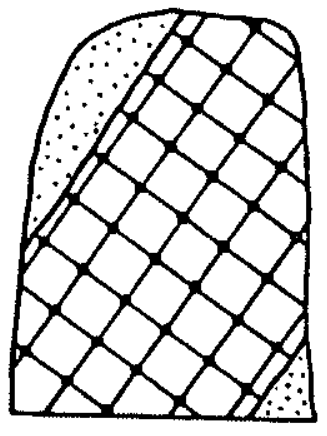

$\checkmark$

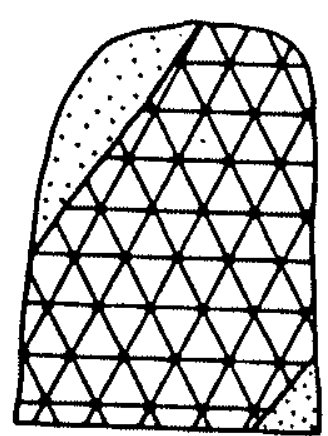

6

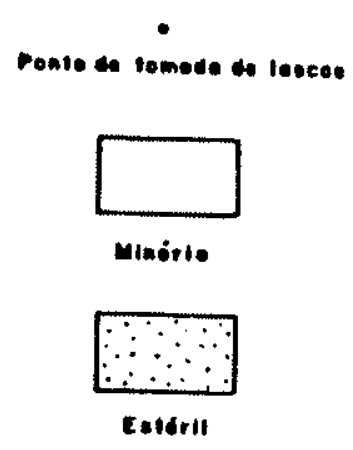

Figura 10: Amostragem por lascas; a: malha quadrada com lado paralelo à parede; $b$ : malha quadrada com lado paralelo ao contato; c: malha romboédrica (Kreiter, 1968).

Segundo Kreiter (1968), a amostra representativa de um depósito mineral com variabilidade regular a extremamente irregular compõe-se de certo número de fragmentos, p.ex., coletados equidistantemente a menos de $20 \mathrm{~m}$, com peso individual aproximadamente igual, conforme ilustrado na Tabela 1.

c - Amostragem por catação ("grab sampling"). Consiste na coleta, por catação ou sucção, de uma grande quantidade de amostras de material que esteja empilhado (p.ex. pilha de desmonte ou rejeito) ou sendo transportado (p.ex. vagonete, carrinho de mão, correia transportadora, e outros). Como ocorre grande enviesamento na amostragem, recomenda-se que se façam duas séries de coletas. 
Tabela 1: Número de fragmentos para composição de amostra conforme a variabilidade do depósito mineral (Kreiter, 1968).

\begin{tabular}{|lcc|}
\hline $\begin{array}{l}\text { VARIABILIDADE } \\
\text { DO DEPÓSITO MINERAL }\end{array}$ & NÚMERO DE & PESO DO \\
\hline Fegular & 25 & FRAGMENTO \\
irregular. & $25-50$ & $100 \mathrm{~g}$ \\
muito irregular & $50-75$ & $100 \mathrm{~g}$ \\
extremamente irregular & $75-100$ & $200 \mathrm{~g}$ \\
\hline
\end{tabular}

Neste tipo de seleção é necessário que alguns cuidados sejam observados como p.ex.:

- o material transportado ou empilhado raramente está suficientemente bem misturado;

- o coletor da amostragem tem a tendência de recolher não só fragmentos mais enriquecidos, como também os mais grosseiros, e ainda os da superficie em detrimento dos do interior do volume da pilha de material.

A quantidade ideal da amostra e a execução desse tipo de amostragem dependerão de fatores como: natureza da mineralização, tamanho dos fragmentos maiores, viabilidade no tratamento e rapidez na rotina do processo.

Para a composição da amostra retiram-se fragmentos ou porções de volumes constantes de material, em cada nó de uma malha reticulada imaginária semelhante à usada na coleta de amostras por lascas, succionando ou paleando-se (escavado com pá) material de diferentes granulometrias.

Outra modalidade do processo e dos critérios adotados em algumas minas consiste, por exemplo, em:

- espalhar, de forma igual, sobre um pátio concretado, todo o material quebradiço da frente de interesse. Em cada nó de uma malha regular estabelecida sobre esse material é recolhida uma amostra cujo peso é registrado juntamente com a posição do nó. Após análise, obtém-se o teor total por ponderação: peso $\mathrm{x}$ teor das amostras individuais;

- amostrar em cada vértice de uma malha imaginária, como do caso anterior, o material transportado em caçamba. As amostras são juntadas e misturadas aos pares 
de caçambadas. $O$ peso e o teor de cada amostra composta são usados para o teor global;

- retirar uma porção ou o conteúdo de uma mão a cada, por ex., $3 \mathrm{t}$ de material transportado em caçamba e misturado para compor uma amostra. Após moagem retira-se uma amostra de aproximadamente $1500 \mathrm{~g}$ para análise. O resultado assim obtido é representativo de $20 \mathrm{t}$ de material desmontado (Dome Gold Mine, Ontário, in Annels, 1991).

d - Amostragem de Sedimento de Corrente. Amostras de sedimento geralmente são coletadas em pontos de um riacho onde a força da correnteza é baixa. Prefere-se areia de granulometria fina até argila, suficientes para formarem $300 \mathrm{~g}$ de amostra. Elas podem ser coletadas a mão, com vasilhame de plástico, madeira ou alumínio.

e - Amostragem por Concentrado de Minerais Pesados. A amostra para o concentrado deve ser coletada em pontos da drenagem onde a energia de fluxo é alta, ou seja, onde os minerais pesados se concentram naturalmente. Os pontos ideais para amostragem são, p.ex., cascalhos basais, porções internas de uma curva da drenagem, sedimentos depositados em obstáculos e outros. O concentrado de minerais pesados é obtido com o bateamento de toda amostra inicial (p.ex. 20 litros). Este é um trabalho válido na garimpagem de ouro e cassiterita, e tem sido usado para deteç̧ão de minério e como bom indicador petrológico regional.

f - Amostragem de solo. O topo do horizonte "B" é aceito universalmente como a amostra média mais representativa da dispersão hidromórfica (Chand, 1981). A posição do horizonte está em profundidade variável em função das condições fisiográficas. Normalmente ele se posiciona exatamente abaixo do nível orgânico, numa camada de argila, óxido de ferro e concentrações de metais-base. A amostragem de solo normalmente é feita segundo espaçamentos, sistemáticos o tanto quanto possível, com uma "prancheta" (p.ex., $25 \times 40 \mathrm{~cm}$ ) ou com um furo de trado para obter aproximadamente $50 \mathrm{~g}$ de amostra na fração 80 mesh. Essas amostras devem ter registro de coordenadas, cotas topográficas, profundidade da amostra, horizonte, características do solo, tipo de rocha, vegetação, relevo etc. Normalmente as análises são feitas em laboratório para os elementos $\mathrm{Ag}, \mathrm{Cu}, \mathrm{Mo}, \mathrm{Pb}, \mathrm{Sn}, \mathrm{W}, \mathrm{Zn}$ - e às vezes $\mathrm{As}$ - e outros elementos específicos da pesquisa.

g - Amostragem de Canal. É o tipo convencional. Consiste em arranhar ou cortar um canal estreito e linear ao longo da face de minério aflorado e em exposições subterrâneas (parede de galerias e poços; frentes de lavra; piso; teto, etc) em pesquisa. A profundidade e a largura desse canal devem ser mantidas uniformemente em poucos centímetros (por ex., $5 \times 10 \mathrm{~cm}$ ), para não tornar-se um trabalho moroso e dispendioso. As ferramentas de uso podem ser marreta, martelo, pontalete e talhadeira (preferencialmente de aço); martelete pneumático manual com pontalete e cinzel; ou serras diamantadas para o corte das laterais do canal. Os recipientes coletores dos fragmentos são lençóis de lona, lençóis plásticos ou caixas posicionadas abaixo do 
canal. Para a coleta da amiostra deve-se proceder, antes, à remoção de rochas instáveis e com partes salientes bem como à limpeza (lavagem/ar comprimido/varredura) do local de amostragem e dos equipamentos, para se evitar contaminação. As amostras devem ser individualizadas, e o comprimento delas medido por zonas ou intervalos, segundo comprimentos constantes estabelecidos na mina, ou nas mudanças de feições geológicas, mineralógicas ou de teor.

O canal é aberto sempre perpendicularmente ao mergulho das zonas de minério. Registram-se tanto as medidas do canal quanto a atitude da zona de minério, para se calcular a espessura real.

A menos que não haja outra opção, devem-se evitar as amostras de piso devido à probabilidade de contaminação. As rochas encaixantes também são amostradas, a não ser que o minério esteja muito bem delimitado.

Annels (1991) cita que a fragmentação e variação na dureza da rocha dificultaram o trabalho da amostragem por canal e, por conseguinte, o método fracassou e foi substituído pela amostragem por lascas de rocha.

Como exemplo ilustrativo, as dimensões recomendadas por Kreiter (1968), para esse tipo de amostragem, estão na Tabela 2.

Tabela 2: Dimensão da seção de canais retangulares (largura $x$ profundidade em $\mathrm{cm}$ ), em função do grau de regularidade do corpo de minério (Kreiter, 1968).

\begin{tabular}{|lcccc|}
\hline CARÁTER DA & ESPESSURA DO CORPO DE MINÉRIO $(\mathrm{m})$ \\
MINERALIZAÇÃO & $>2,5$ & $2,5 \mathrm{a} 0,5$ & $<0,5$ \\
\hline muito regular e regular & $5 \times 2$ & $6 \times 2$ & $10 \times 2$ \\
irregular & $8 \times 2,5$ & $9 \times 2,5$ & $10 \times 2,5$ \\
muito irregular e & $8 \times 3$ & $10 \times 3$ & $12 \times 3$ \\
\hline extremamente irregular & & & \\
\hline
\end{tabular}

Mesmo assim, esse tipo de amostragem é indicado para quase todos os depósitos minerais, exceto para os de formato irregular, para minérios brechados (resultados com erros sistemáticos), para mineralizações de Au e Pt em pequenos corpos (efeito pepita) e para depósitos pegmatíticos. 
h - Amostragem por Poços. Este tipo de amostragem consiste na coleta de material mediante escavaçâo vertical de uma abertura com seção circular ou retangular (p.ex. $1 \mathrm{~m}$ de diâmetro ou $0,60 \times 0,80 \mathrm{~m}$ ) através do "overburdem" até o interior do embasamento alterado. As ferramentas de uso são, normalmente, pás, picaretas, alavancas ou marteletes pneumáticos. $\mathrm{O}$ produto dessa escavação é embalado e içado com auxílio de sarilho ou guincho.

A escavação é um trabalho pesado, vagaroso e pode ser interrompido devido ao desmoronamento de zonas pedregosas ou friáveis presentes no perfil do solo; às espessas zonas de lateritas; ao alto nível do lençol freático.

Normalmente os poços são alinhados perpendicularmente à direção de anomalias geoquímicas, equidistantes em até $5-10 \mathrm{~m}$, e podem atingir profundidades de $15-20 \mathrm{~m}$. Eles permitem que o geólogo mapeie as paredes do poço e identifique a litologia, tipo de embasamento, estrutura, a provável mineralização e execute amostragem por canal bem como por amostras volumétricas. $\mathrm{O}$ acréscimo de informações permite a elaboração de perfis geológicos com valores geoquímicos e o fornecimento de maior precisão na avaliação de uma zona mineralizada ou no posicionamento dos furos de sondagem, para a investigação em profundidade.

i - Amostragem por Trincheiras. É um tipo de amostragem executado à superficie mediante escavação - manual e mecânica (retroescavadeira, escavadeira com caçambas ou tratores) - de abertura linear e preferencialmente horizontalizada, perpendicular à maior dimensão do corpo mineralizado, para expor o embasamento mineralizado onde a cobertura não seja muito espessa. A largura e a profundidade da trincheira são determinadas em função do objetivo da amostragem, dos equipamentos de trabalho disponíveis e da estabilidade dos taludes, ao passo que o comprimento depende da anomalia geoquímica ou da natureza da mineralização.

As trincheiras permitem que se delineie o corpo de minério, sejam reconhecidas algumas características geológicas e executados outros tipos de amostragem como a de canal e a volumétrica.

j - Amostragem por Túneis ou Galerias. Túneis e galerias são aberturas executadas à subsuperficie mediante escavação - manual ou mecânica - do maciço rochoso ou do corpo de minério. Eles permitem: realização de análises geomecânicas in situ; coleta de amostras indeformadas para ensaios laboratoriais; coleta de amostras volumétricas; execução de sondagens internas direcionadas; execução de amostragens de todos os tipos (fragmentos, lascas, de canal, catação e outras já citadas).

Galerias, poços e shafts são os tipos de amostragem mais eficientes na pesquisa subterrânea. Como esses trabalhos são onerosos e demorados, eles são preferencialmente mais utilizados na pesquisa dos depósitos com formato irregular e de teores aleatórios.

Os poços são aberturas de até $30 \mathrm{~m}$, semelhantes aos furos verticais. Eles servem para amostrar corpos de minério com pouca inclinação, próximos à superficie. Também podem abrir-se 
poços nas laterais de rampas e nas galerias, por espaços, regulares ou não, e utilizá-los como poços de prova e de amostragem volumétrica.

A abertura de túneis é viável somente nos lugares de relevo bastante forte: eles são usados para a exploração de corpos de formato e modo de ocorrência variáveis.

k - Amostragem por Sondagem. A sondagem representa uma técnica investigatória de um corpo de minério na subsuperficie, mediante a recuperação de amostras através de furos de sondagem. Essas amostras são logradas na forma de testemunhos inteiros ou de fragmentos. Podem ser usadas para avaliação de um prospecto, para testes de recuperação (beneficiamento) e ampliação da reserva mineral. Tais furos ainda fornecem informações de caráter geológico, usadas para testes geomecânicos e para controle dos teores e do desenvolvimento da mina.

Um fator importante na amostragem, independentemente de ser fragmento ou testemunho, é medir cuidadosamente o volume ou comprimento da amostra para compará-lo com a medida teórica. Essa razão percentual da medida do material recuperado com a perfurada é a recuperação. Mesmo sendo ela baixa, a adoção cuidadosa de técnicas especiais de amostragem (com revestimento ou embuchamento) viabiliza a coleta de testemunho em rochas macias ou nos sedimentos.

Além da recuperação, outro fator de importância ideal na sondagem é que o diâmetro dos testemunhos atenda à massa exigida para representar o material que se deseja amostrar em função da variabilidade do depósito pesquisado. $\mathrm{Na}$ investigação de depósitos minerais, esse tipo de amostragem é o mais rápido e o de maior eficácia dentre os demais.

Entre as técnicas de sondagem mais utilizadas na pesquisa mineral e, por conseguinte, na amostragem estão:

K.1 - Sondagem rotativa a diamante. Efetuada em quase todos os pontos tanto de superficie como de subsuperficie - com motores de propulsão a diesel, elétricos ou de ar comprimido, ela possibilita furos direcionados para qualquer ângulo: é a única técnica capaz de fornecer registro completo da estrutura geológica e da textura das rochas. As amostras são recortadas por uma coroa diamantada, recuperadas dentro de um tubo de barrilete e alçadas à superficie. Normalmente os barriletes têm capacidade para 1,5 a $3 \mathrm{~m}$ de testemunho e comprimento de até $6 \mathrm{~m}$ de comprimento. $\mathrm{O}$ diâmetro dos testemunhos também pode variar de $18,3 \mathrm{~mm}$ até $165,1 \mathrm{~mm}$, de acordo com o código de diâmetro do equipamento escolhido (por exemplo: $\mathrm{BX}=42,1 \mathrm{~mm} ; \mathrm{NX}=54,8 \mathrm{~mm}$ ) ou disponivel para uso. Para lubrificar coroa e testemunho, estabilizar e selar parede dos furos e testemunhos, bem como para transportar fragmentos à superficie, utiliza-se, na maioria das vezes, água com argilas pesadas ou outros aditivos.

Essa técnica de sondagem rotativa, conquanto seja de custo elevado mas de baixo rendimento, tem, no entanto, sobre as demais, as seguintes vantagens: 
- propicia obtenção de amostras contínuas e de volume constante das zonas mineralizadas;

- garante boas informações geológicas, mineralógicas e geotécnicas da região;

- permite que a divisẫo e a amostragem dos testemunhos sejam processadas quase com nenhuma contaminação.

K.2 - Sondagem rotary. Os equipamentos de sondagem rotary são montados normalmente sobre caminhões. Eles são mais pesados do que as sondas a diamante, menos flexíveis nos pontos de sondagem e com limitações para sondagem de furos inclinados. A sondagem rotary fornece amostras de fragmentos ou lascas de rocha de poucos milímetros, os quais ascendem à superficie numa corrente de ar, espuma ou lama. Com a descrição dos fragmentos pode-se identificar a mineralogia e o tipo de rocha perfurada, mas se perdem todas as informaçôes sobre sua textura e estrutura. Secos ou úmidos, os fragmentos são guardados em caixas ou coletados e separados por ciclonagem, filtros ou peneiras.

\section{K.3 - Sondagem de testemunhagem contínua e sondagem tipo circulação}

reversa. Esses dois tipos de sondagem são variações da sondagem rotary; possuem custos operacionais mais elevados do que a rotary convencional, mas recuperam amostras de fragmentos maiores. A primeira recupera pedaços cilíndricos de testemunho na ascensão de fluído pelo centro do revestimento de parede dupla - contrário ao circuito normal de bombeamento na sondagem. A sondagem tipo circulação reversa utiliza uma columa de tubos duplos e o ar, injetado sob pressão pelo intervalo anular entre os tubos, retorna à superficie pelo interior do tubo interno, carreando continuamente as amostras que foram cortadas por uma coroa especial. Um tubo flexível conduz o material até um ponto de coleta, onde é classificado automaticamente através de peneira e ciclone acoplados. Os equipamentos são montados em caminhão ou trator de rodas e produzem amostras não contaminadas à velocidade entre 1000 e $2000 \mathrm{~m} / \mathrm{mês}$ de perfuração. Esta técnica permite furos com diâmetro de até 8 polegadas e recuperação média quase total, para formações inconsolidadas ou duras.

K.4 - Sondagem a Percussão. Esse tipo de sondagem permite a abertura de um furo na rocha, percussionando-se uma haste com broca de aço, calçada por uma sonda pneumática ou hidráulica ("blast hole drill"), ou por outra com um martelo de fundo ("down hole hammer drill"). Estes furos podem ser localizados em superficie ou a partir de estações subterrâneas.

A sondagem convencional ("blast hole hammer drill") possibilita furação a qualquer ângulo, pois possui um mecanismo que permite combinar rotação com percussão. As amostras, em forma de finos fragmentos de rocha, são recuperadas no 
contrafluxo da água ou ar injetados por dentro da haste até aiguns orifícios na face da broca.

A sonda com martelo de fundo ("down hole hammer drill") pode abrir furos com diâmetro de até $100 \mathrm{~mm}$ e à profundidade média de $300 \mathrm{~m}$. A sonda possui rotaçâo hidráulica fora do furo e percussão pneumática transmitida diretamente à broca. A coleta de amostra se faz da mesma maneira que a do caso anterior.

Outro tipo de sondagem a percussão é a furação a cabo ("churn drilling"). Um conjunto de hastes e trépano de aço na forma de bisel é içado por cabos de aço como num guincho. $\mathrm{O}$ motor, acionado alternadamente, suspende e solta os equipamentos de modo que o trépano fragmente a rocha abrindo-se o furo. A amostra pode ser coletada num amostrador de limpeza, com válvula de tamponamento, ou no contrafluxo de fluído injetado.

K.5 - Sondagem a Trado manual ou mecanizado. A sondagem é executada com um trado sem revestimento, que fura o terreno. $O$ trado, com diâmetro de 3 a 8 polegadas, pode ser de vários tipos (concha, IPT, espiral, e outros); possui punho adaptado a uma haste e penetra no solo mediante rotação e pressionamento. Muitos deles são mecânicos e podem estar adaptados a caminhões, tratores - ou portáteis. Usa-se esse equipamento em depósitos inconsolidados e na pesquisa de argilas. A amostragem obtida é de precisão duvidosa, embora se faça a coleta de amostras em intervalos regulares.

K.6 - Sondagem tipo Banka. É uma sonda manual muito utilizada na pesquisa de aluviões, que possibilita amostragem com precisão satisfatória até $10 \mathrm{~m}$ de profundidade. Uma sapata denteada ou em bisel, acoplada em um tubo, é introduzida no solo em movimentos de rotação ou percussão manual - neste caso, batendo-se com um "martelo de madeira" sobre o cabeçote. $O$ material introduzido pelo revestimento, a cada intervalo de avanço (p.ex., $25-50 \mathrm{~cm}$ ), é removido com amostradores de válvula. Existem versões mecanizadas da sonda tipo Banka disponiveis no mercado brasileiro (p.ex., SP-150Equipegeo Ltda).

K.7 - Sondagem Empire Jet. Ela é usada na pesquisa de depósitos residuais e possibilita uma rápida avaliação qualitativa da região. Um tubo de revestimento de 3 polegadas de diâmetro é introduzido no solo mediante movimentos rotativos e percussivos. O material coletado no intervalo de cada avanço (p.ex., $50-100 \mathrm{~cm}$ ) é desagregado dentro da tubulação por jato d'água de 1". Os fragmentos são transportados à superficie na corrente de fluxo e recuperados em calha. O processo de furação é rápido e permite atingir 10 a $20 \mathrm{~m}$ de profundidade. 


\subsubsection{O componente estatístico}

Este componente responde principalmente pela quantidade de amostras e pelo modo como elas são selecionadas para os fins a que a amostragem se destina.

\subsubsection{O número de amostras}

A teoria da amostragem é construída em torno de um conceito de que, se um número significativo de amostras for coletado sem enviesamento, o valor médio das observações irá aproximar-se à média da população.

O número de amostras, segundo Koch \& Link (1971), a ser coletado num programa de amostragem, depende:

- da variabilidade associada a cada uma das várias fontes - natural, amostragem, preparação e analítica;

- da estatística ou estatísticas a serem determinadas - média, desvio-padrão, coeficiente de variação ou outro;

- da forma de distribuição das estatísticas - normal, lognormal ou outra - e como estas formas são conhecidas;

- da precisão requerida;

- da exatidão requerida;

- do custo da amostragem, incluindo planejamento, coleta das amostras, preparação e análises químicas.

\subsubsection{Métodos de amostragem}

Para que se tornem validamente representativas as porções geológicas retiradas de um corpo de minério - visto que este, por natureza, é, na proporção de sua massa, uma mistura de minerais - faz-se necessário que a amostragem pressuponha:

- aleatoriedade na retirada da amostra;

- conveniência de volume ou peso das amostras;

- disponibilidade do material e

- suficiência do resultado em face até da perda de uma amostra. 
Atualmente, os principais métodos de amostragem são:

a- Amostragem aleatória simples;

b- Amostragem aleatória estratificada e

c- Amostragem sistemática.

Jones (1987) definiu-os como:

a - A amostragem aleatória simples consiste na seleção de todos os valores possiveis de um atributo sob investigação, considerando-se para cada um deles igual probabilidade de ser selecionado na amostragem.

b - A amostragem aleatória estratificada consiste na divisão de uma população total em determinado número de subpopulações (estratos) convenientes. Depois de escolhidos os estratos, seleciona-se aleatoriamente uma quantidade de amostras em cada um deles para compor uma amostra principal por população.

c - A amostragem sistemática consiste na coleta de amostras de uma população total a partir de procedimentos cíclicos, segundo intervalos regulares préfixados. Por exemplo: estabelecer uma malha regular dentro da área de interesse, a partir do posicionamento de uma linha base; ou, fazer o produto de moinho não coincidir com os pontos máximos ou mínimos da moagem.

Esse método é sempre utilizado e indicado para a pesquisa de depósitos minerais.

\subsubsection{O conceito de viés e de variância do erro mínimo.}

A necessidade de pesquisa de depósitos minerais com teores marginais e, também, o aprimoramento de controle do beneficiamento têm exigido processos de amostragem corretos e resultados cada vez mais exatos.

Um resultado analítico quantitativo pode ser apenas uma estimativa da concentração do elemento presente. Uma medida de confiança dessa estimativa é dada estatisticamente por dados decorrentes da precisão e exatidão das medidas com que se deveria acompanhar a estimativa, quando ela é referida como resultado analítico.

A Figura 11 ilustra os conceitos de exatidão (ou enviesamento) e precisão de uma amostragem, conforme Pitard (1992).

A precisão de uma estimativa é uma medida de ajuste entre valores repetidos, ou, segundo Waeny (1979), mostra a dispersão dos resultados em torno de um valor de referência tido como correto. Uma estimativa quantitativa da precisão pode ser obtida com a variância e o desviopadrão do conjunto de resultados. 

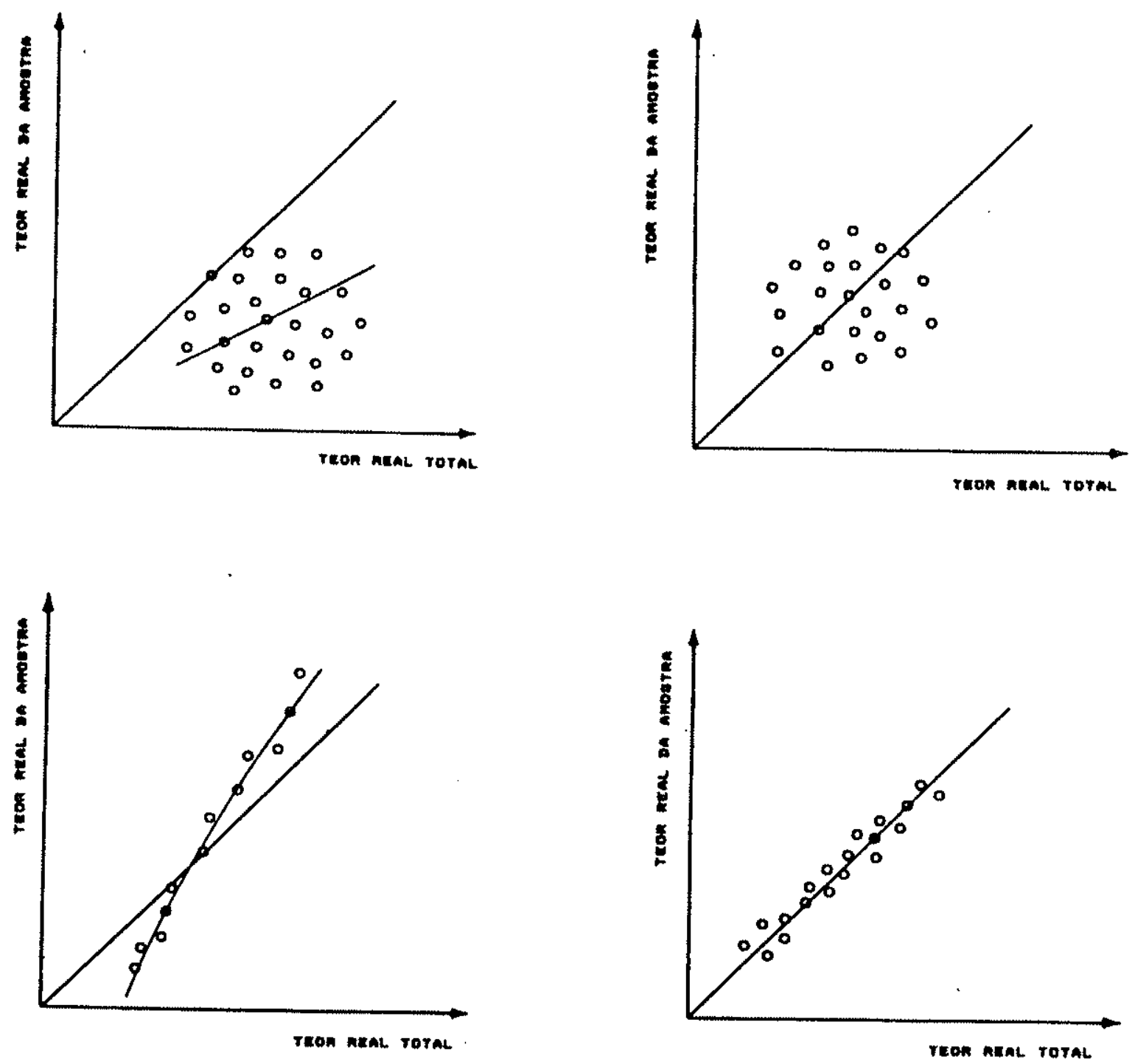

Figura 11. Exatidão e Precisão: A - A amostragem é emviesada e imprecisa (um dos casos mais frequentes); $B$ - A amostragem não é precisa. Não podemos dizer a amostragem é exata visto que não há correlação entre o teor real da amostra e o teor real total; $C$ - A amostragem é enviesada e precisa (seguindo leis desconhecidas); D - A amostragem é exata e precisa. (Pitard, 1992).

A exatidão de resultado é a concordância entre ele e o valor real ou o mais provável (Johnson \& Maxwell, 1981); a diferença numérica entre os dois valores é o erro. A exatidão de uma estimativa pode ser quantificada pelo intervalo de confiança associado a ela, e definido como: 


$$
\frac{t s}{\sqrt{N}}
$$

onde "s" é o desvio-padrão; " $\mathrm{N}$ " é o número de medidas, e " $t$ " é o valor $t$ de student.

Para explicar "enviesamento", Ingamells (1987) revela que "uma amostra é uma porção da massa de material, mas ela não é necessariamente uma porção representativa do todo. Se a massa é heterogênea, sua composição em relação ao elemento de interesse " $\mathrm{X}$ " poderá ser avaliada mediante análise de muitas amostras, sem que a composição de uma delas corresponda exatamente com a da massa inteira". Assim, para entender como pode acontecer o enviesamento, a despeito de a preparação da amostra ter sido cuidadosa, sempre existirá uma grande diferença entre o teor real de uma parte do testemunho e o teor da amostra de laboratório.

Dos vários critérios estatísticos utilizados para a escolha de um estimador estatístico de um determinado parâmetro de uma população, os dois mais importantes são os seguintes:

- que o estimador estatístico seja um estimador não enviesado do parâmetro da população;

- que o estimador seja eficiente.

Um estimador não enviesado é o que tem distribuição amostral com média igual ao do parâmetro estimado. Por exemplo, a média amostral é um estimador não enviesado da média populacional, mas o desvio-padrão amostral é um estimador enviesado do desvio-padrão populacional. O enviesamento " $\delta$ " é igual à diferença entre o valor médio do estimador estatístico e o do parâmetro que está sendo estimado. Assim, para o exemplo:

$$
\begin{aligned}
& \delta=\mu_{\bar{w}}-\mu=0, \text { mas } \\
& \delta=\mu_{s}-\tau \neq 0
\end{aligned}
$$

Apesar de serem desejáveis os resultados não enviesados, estimadores com pequeno enviesamento, por exemplo, o desvio-padrão amostral, podem ser perfeitamente aceitáveis e usados para algumas finalidades.

O segundo critério é que um estimador seja eficiente. Eficiente é o estimador estatístico que, para determinado tamanho de amostra, tenha o menor erro quadrático de todos os estimadores que podem ser calculados. O menor erro ao quadrado pode ser escrito como:

$$
\text { M.S.E. }=\tau_{g}^{2}+\delta^{2}
$$

onde " $\tau_{g}^{2}$ " é a variância do estimador estatístico " $g$ ", obtido a partir da distribuição de amostragem estatística de " $g$ ", e " $\delta$ " é um enviesamento do estimador estatístico " $\mathrm{g}$ ". Se o 
estimador estatístico é um estimador não enviesado, " $\delta$ " é zero, e a equação do erro quadrático, torna-se:

$$
\text { M.S.E. }=\tau_{g}^{2}
$$

Conforme foi demonstrado por Koch \& Link (1979), a média é conhecida como o melhor estimador estatístico.

$O$ intervalo de confiança é um dos conceitos estatísticos mais usados pela geologia. Com o intervalo de confiança, a variabilidade (medida pelo desvio-padrão), o número de amostras e a média podem ser incorporados numa simples fórmula quantitativa.

O intervalo estimador do parâmetro em estudo é conhecido por ficar entre dois valores (chamados limites de confiança), calculado para uma porcentagem específica do intervalo. Por exemplo: se o granito contém $65,1 \%$ de quartzo, sabe-se que o intervalo de confiança, para o limite de confiança de $90 \%$, fica entre 65,1 e $70,1 \%$ de quartzo.

\subsubsection{O espaçamento entre amostras}

Muito embora a malha de sondagem para fins de amostragem de um depósito mineral tenha sido definida por razões de ordem geológica e econômica, há também a possibilidade de se verificar se a abertura da malha utilizada está ou não dentro de uma determinada área de influência estatística. Esta verificação pode ser feita por meio de uma análise geoestatística de informações como se pode ver a seguir.

Um instrumento importante da análise geoestatística, que permite quantificar esses parâmetros geológicos, é o variograma (Matheron 1963, apud Peters 1987).

Ele é representado pela fórmula:

$$
\gamma_{(h)}=\frac{1}{2 n}(h) \sum_{i=1}^{n}(z(x+h)-z(x))^{2}
$$

onde " $z(x)$ " é o teor da amostra no ponto " $x "$, " $z(x+h)$ " é o teor para um ponto " $x+h "$ ", "h" é a distância e " $n$ " é o número de pares de amostras separados em distância " $h$ ". O valor de $\gamma$ muda conforme aumenta o intervalo (distância) entre os pares de amostras.

O variograma é um gráfico que mostra a afinidade entre a diferença dos valores de um par de amostras, quando se aumenta a distância da posição das amostras numa determinada direção. 


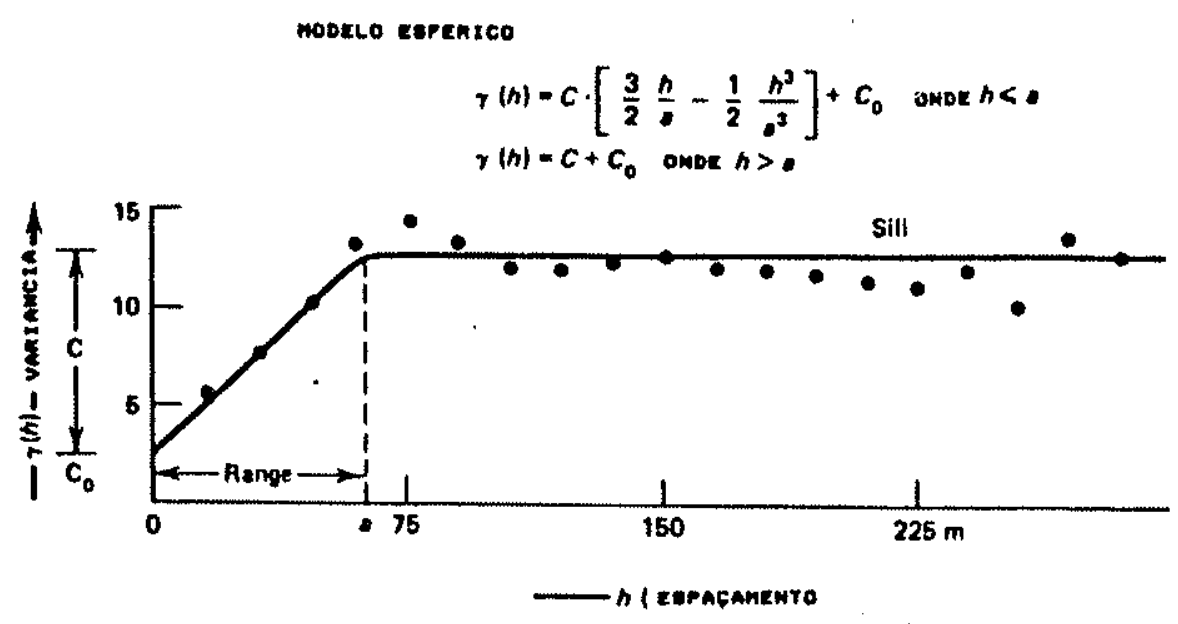

Figura 12. Variograma. Exemplo de um modelo esférico adaptado para valores pontuais de um variograma experimental (Matheron 1963, apud Peters 1987).

Na Figura 12, modelo Matheron ou esférico, quando cresce o espaçamento " $h$ " entre as amostras, aumenta a diferença entre seus valores, até um ponto tal, a partir do qual não se registram modificações de " $\gamma(h) "$. Em outras palavras: não existe dependência mútua das amostras. O variograma é contínuo, com espaçamentos regulares para cada aumento de " $h$ ", cujo valor limite, chamado também de amplitude "a" ou distância de influência (range), corresponde à independência das amostras. Ao valor de " $h$ " igual a "a" corresponde, na ordenada " $\gamma(h)$ ", um valor " $\mathrm{c}$ " denominado patamar.

Entre outros modelos de variograma, o modelo esférico tornou-se o mais importante dos instrumentos essenciais e tem sido adotado pelos geoestatísticos em quase todo o mundo.

Ele é definido pela seguinte fórmula:

$$
\begin{aligned}
& \gamma(h)=C_{0}+C\left[\frac{3}{2} \frac{h}{a}-\frac{1}{2} \frac{h^{3}}{a^{3}}\right] \text { para } \mathrm{h}<\mathrm{a} \\
& \gamma(h)=C_{0}+C \text { para } \mathrm{h}>\mathrm{a}
\end{aligned}
$$

O espaçamento máximo admitido entre amostras numa certa direção seria a distância ou zona de influência mostrada pela amplitude do variograma. A aproximação normalmente sugerida fica entre $2 / 3$ e $3 / 4$ da amplitude. 


\subsection{Preparação de amostras}

Importa, neste ponto, referir, ainda que sucintamente, a importância, o objetivo da preparação de amostras, alguns métodos físicos e alguns problemas relacionados a ela.

A preparação é um procedimento importante dentro do capitulo de amostragem, e Pitard (1992) a define "como uma seqüência de operações não seletivas que pode passar pela britagem, moagem, pulverização, secagem, mistura, etc, e levar uma quantidade de massa, sob forma conveniente, para um novo estágio de processamento, que pode ser outro estágio de amostragem ou a análise final".

A preparação pode iniciar-se no campo, mas a maioria é feita no laboratório sob controle e responsabilidade, direta ou não, do geólogo ou engenheiro de minas. Geralmente os laboratórios são muito confiáveis e asseguram os controles exigidos pelos geólogos. Como a ocorrência de erros é inevitável, utiliza-se, como prática, a remessa de amostras duplicatas, amostras padrão e ensaios de "check" entre laboratórios, para determinar o nivel de confiança e detectar um possivel enviesamento. Quer feita no campo ou no laboratório, a preparação de amostras, segundo Koch \& Link, (1971) tem dois objetivos principais:

a- homogeneização e

b- redução da quantidade da amostra geológica.

Uma amostra coletada de um corpo de minério ou de uma planta de tratamento pode pesar dezenas ou centenas de quilogramas. Antes de ser analisada, a massa desse material terá seu peso reduzido significativamente, conforme ilustrado pela Figura 13. A quantidade de material necessário para formar uma boa amostra é função do tamanho das partículas. Para garantir tamanho menor das partículas, frequentemente se processa a britagem tanto antes da homogeneização como da redução da mssa inicial. Sem britagem, a homogeneização de todo o volume é impossivel; sem homogeneização, qualquer redução no volume produzirá enviesamento. Amostras com grãos grosseiros devem ser passadas por um pequeno britador ou quebradas com um martelo.

$\mathrm{Na}$ preparação de testemunhos de sondagem rotativa a diamante, uma metade é homogeneizada, ao passo que a outra geralmente é guardada em caixas de testemunhos apropriadas. Assim se deve proceder, porque, se há relativa facilidade de coletar uma amostra de campo, é impossível repetir o mesmo furo. O testemunho pode ser cortado ao meio por "partidores de testemunhos" ou por serras diamantadas. O uso de serras propicia um corte preciso do testemunho e fornece um volume de amostra sempre constante; o "partidor de testemunho" fragmenta-o totalmente e nem sempre a partição se faz ao meio. Uma metade vai sofrer os processos de preparação de amostras e a outra metade vai para a descrição macroscópica da litologia e será arquivada pelo tempo que se fizer necessário. 


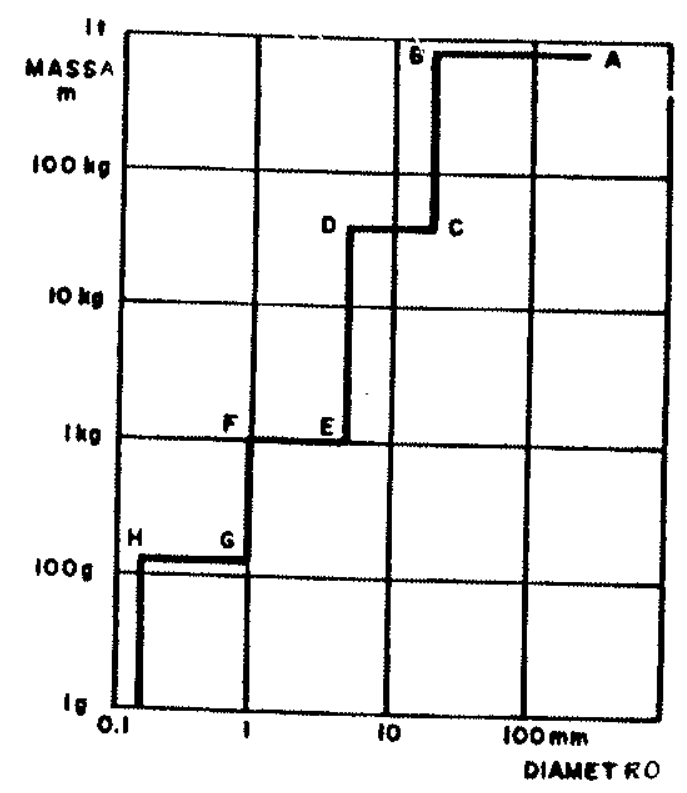

Figura 13. Representação esquemática da preparação da amostra. Cada ponto representa uma certa quantidade de material moido para um determinado tamanho. A preparação de uma amostra é uma redução sucessiva de peso e tamanho dos grãos (David, 1988).

A Figura 14 apresenta um resumo dos estágios de amostragem aplicados em testemunhos de sondagem, segundo Jones (1987).

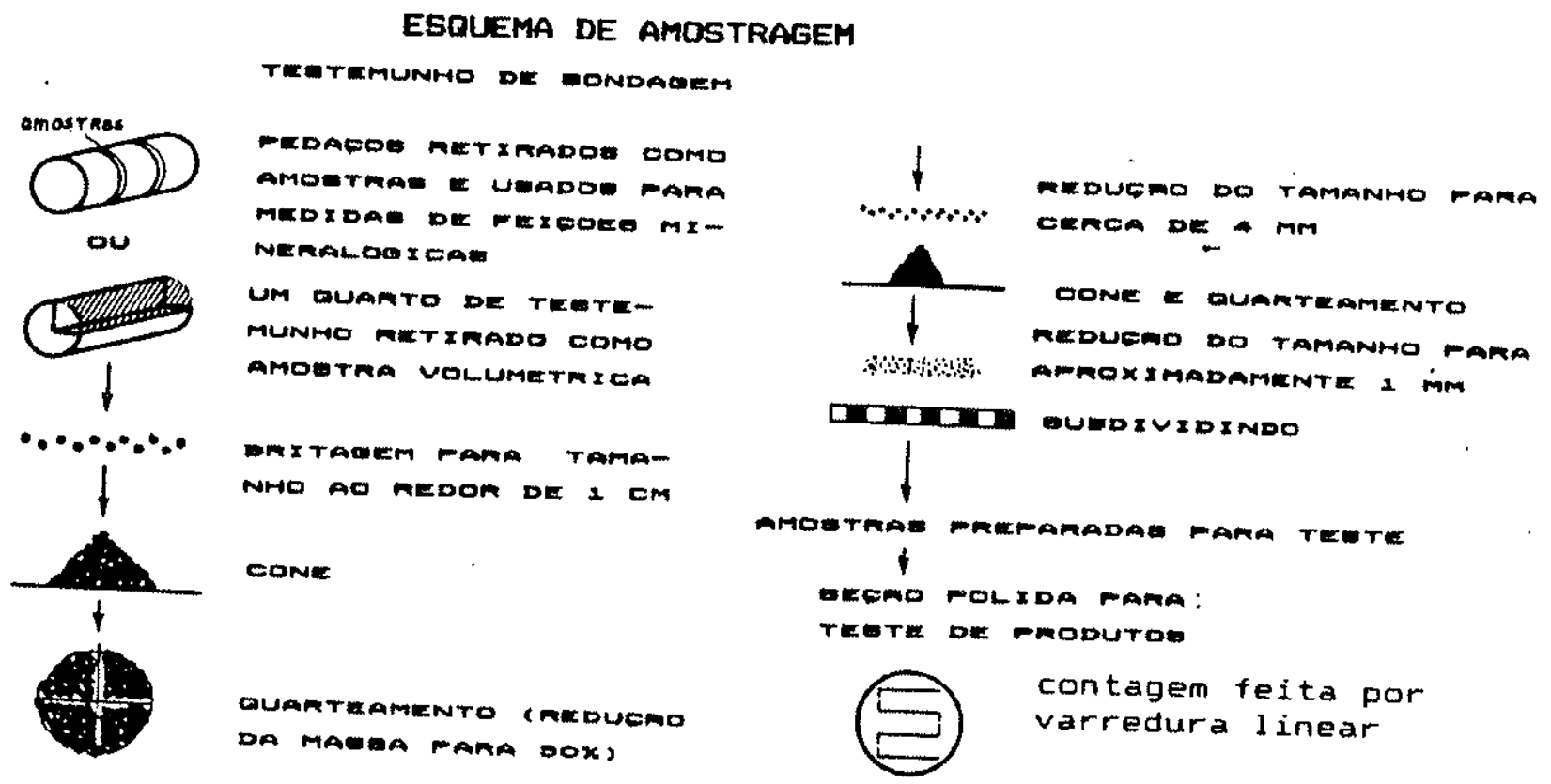

Figura 14. Resumo dos estágios de amostragem aplicados na coleta de amostras de testemunhos de sondagem (Jones; 1987). 
Os problemas na preparação de amostras, discutidos por Koch \& Link (1971), são as perdas sistemáticas, contaminação, mistura, concentração, subdivisão e alteração.

Quando as amostras são pulverizadas, a cadà operação perde-se sistematicamente determinada quantidade de material. Tais perdas podem ser controladas, pesando-se as amostras em cada etapa da preparação e considerando-se que elas terão peso maior com a contaminação, e menor com a perda.

A contaminação durante a preparação pode-se dar com a introdução de material estranho na amostra, diminuindo o teor do elemento de interesse ou, também, aumentando-o quando se infiltrar material mineralizado. A contaminação proposital com o objetivo de aumentar os teores do elemento de interesse nas amostras é chamado "salgamento". Outra forma de contaminação pode ocorrer durante os processos de britagem/moagem da amostra com a introdução de traços de metais utilizados nas ligas desses equipamentos.

A mistura tem por objetivo a homogeneização do material para a retirada de quantidade adequada para análise. Entretanto, devido à grande variabilidade dos materiais geológicos, é extremamente dificil conseguir uma mistura ideal de todos os componentes. Nesse caso, para garantir a melhor amostragem, a homogeneização deve ser feita com o material reduzido a uma granulação tão pequena que garanta a distribuição homogênea de todos os componentes no volume da amostra.

Para a redução da quantidade de material, a técnica da subdivisão é a melhor. O seu maior problema está em garantir que o material dividido apresente a mesma quantidade do elemento de interesse em todas as suas porções, ou seja, igual probabilidade de apresentar o elemento de interesse nas porções divididas.

A alteração é problema específico de certos minerais que podem reagir durante a preparação (secagem em estufas, oxidação em contato com o ar, etc), deteriorando, por conseguinte, o resultado analítico.

A preparação de amostras, segundo Koch \& Link (1971), compreende vários métodos de preparação agrupados de acordo com os seguintes processos físicos ou químicos utilizados:

a- Concentração. Separação fisica dos minerais de interesse da amostra visando sua concentração para análise. Não se deve esquecer, neste caso, a relação peso inicial e peso de concentrado para se estabelecer, no cálculo do teor do elemento de interesse na amostra, a proporção existente. A concentração fisica dos minerais de interesse pode ser feita por lavagem, concentração gravimétrica, separação com líquidos pesados, flotação, elutriação, peneiramento, separação magnética, separação eletrostática e separação manual. Esses métodos são indicados, como exemplo, para sedimentos e rochas sedimentares inconsolidados ou fracamente consolidados, principalmente para aqueles 
com grãos de diverso tamanho, forma, peso específico, propriedades magnéticas ou eletrostáticas;

b. Lixiviação ou Outros Processos Químicos. Permite fazer a concentração química de elementos de interesse na amostra geológica, liberando tais elementos da estrutura da rocha ou de minerais, para posterior análise. Esta concentração pode ser feita por solução em água, água régia, ácido clorídrico a quente, cianetação e outros reagentes conforme o caso. Inclui-se, neste caso, a amalgamação, que produz uma liga de mercúrio, prata e ouro. A concentração química é indicada para rochas ou minerais solúveis;

c- Pulverização. Consiste na redução da granulometria do material amostrado para melhor homogeneização e coleta de porção representativa da amostra primária, para posterior análise. Os trabalhos de laboratório compreendem geralmente a secagem, britagem - para reduzir a granulometria compativel com os moinhos -, moagem e pulverização. Este processo é indicado para amostras de mão, de canal, de fragmentos, de testemunhos de sondagem, entre outros;

d-Subdivisão. "É usado para dividir material fragmentado - desde que este esteja originalmente desagregado tal como cascalho, solo ou rocha pulverizada - em duas ou mais partes", Kock \& Link, 1971. Este método é geralmente necessário para reduzir o peso da amostra e preparar amostras para análise química. Neste caso a amostra deve ser constituída por fragmentos ou grãos discretos e apresentar granulometria que garanta igual probabilidade de ocorrência do material quarteado. A subdivisão em laboratório pode ser executada por várias técnicas secundárias de amostragem como: "cone e quarteamento", "ponto nove" e "calhas".

- "Cone e quarteamento" é um dos métodos mais eficazes para uso de material grosso, isto é, superior a poucos centímetros. Deve-se construir uma pilha em forma de cone, despejando-se pelo ápice, sobre uma fôrma circular, pequenas porções de material. O segundo passo é comprimir o material até poucos centímetros de espessura e dividi-lo em quatro partes iguais; e o par de porções opostas é descartado ou juntado para novos procedimentos, conforme ilustrado na Figura 15.

- "Ponto nove" é outro método de amostragem usado especialmente para amostrar materiais secos e de granulação fina. O procedimento é semelhante ao anterior, apenas com a subdivisão do material em oito seguimentos iguais. Com auxílio de uma espátula retira-se, à mesma distância radial, uma porção de amostra dentro de cada seguimento. A nona amostra é coletada do centro da fôrma, conforme ilustrado na Figura 16. 
AUMENTC DE WM COME DE

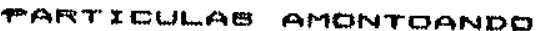

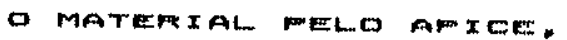

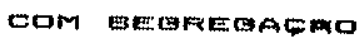

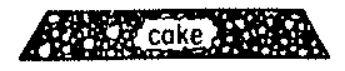

CONE⿱ ACHATADO (EM TAELETER )

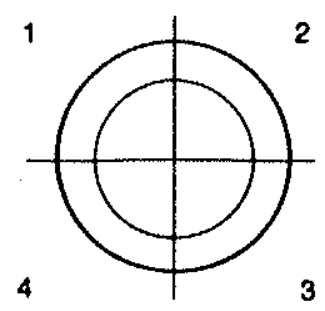

\#EMMNTOE COMFACTADOE

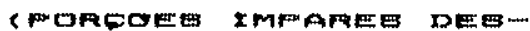

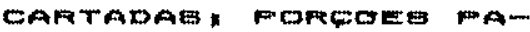
PEE FETXXAS
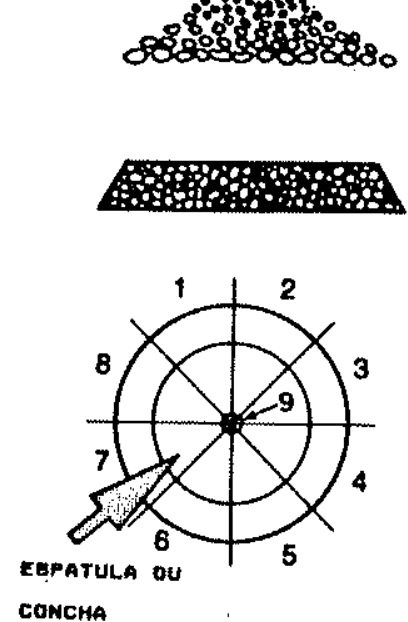

CONE ACHATAXO 世 Maracado em ox To

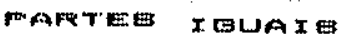

Figura 15. Representaça do étodo de anostragen por "cone e quarteamento" (Jones, 1987).
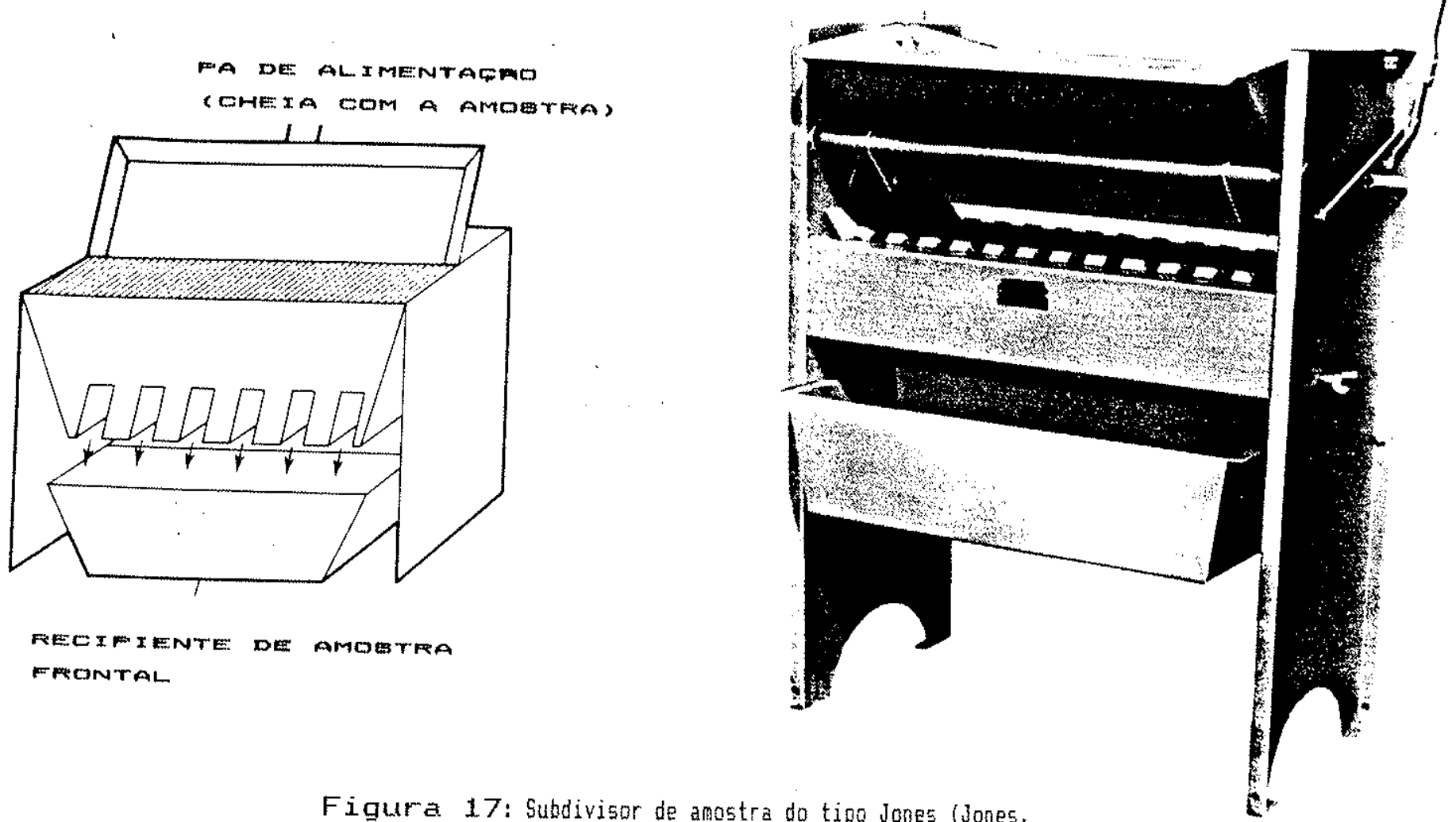

Figura 17: Subdivisor de amostra do tipo Jones (Jones, 1987).

Figura 16. Metodo de amostrage do "ponto nove". Coleta-se oito porcós en seguimentos já dividi dos; o nono ponto é coletado no centro (Jones, 1987). 
- "Calha" é o método de amostragem - normalmente restrito a materiais com partículas de tamanho pequeno (menores do que poucos milímetros de diâmetro) - que se usa comumenie para dividir amostras com auxílio de um tipo de calha ("riffler"). O mais conhecido, denominado "quarteador" Jones, vide Figura 17, é um aparelho que consiste de uma caixa metálica dividida internamente por igual número (normalmente 8 ou 16) de compartimentos (calhas) de idêntica largura - e sempre maior que $2 \mathrm{~d}+5 \mathrm{~mm}$ - onde " $\mathrm{d}$ " é o diâmetro da maior partícula (in Goes et alii, 1991). Estas calhas mergulham a $45^{\circ}$ alternando-se em direções opostas. $O$ material a ser amostrado é espalhado dentro de uma concha (que possui a mesma largura do "riffler") para formar uma camada de espessura uniforme. Em seguida a concha é emborcada sobre o "riffler" e duas porções "iguais" são coletadas por recipientes em cada lado da unidade.

Nesta etapa pode ocorrer erro de preparação em virtude da má subdivisão. Nas Figuras 18 e 19, ilustra-se, respectivamente, a subdivisão errada e a correta. Vale observar que, na Figura 18 , o "quarteamento" é enviesado, porque nem todo o material sofre subdivisão, ao passo que na Figura 19 há maior probabilidade de o material "quarteado" ter as mesmas características do restante, pois representa uma fração do material inicial. No entanto, o procedimento ilustrado na Figura 18 é uma prática quase comum dos laboratórios.

\subsection{Equação de amostragem de Gy}

A redução da amostra geológica e a homogeneização constituem os principais objetivos da preparação de uma amostra. Procede-se à homogeneização do material original pela redução de sua granulometria e respectivas misturas em laboratório, até a retirada de uma quantidade representativa para análise. $O$ primeiro problema da preparação está em equacionar a massa mínima ideal para análise de material, depois de conhecido o diâmetro das partículas.

As primeiras tentativas foram realizadas de modo determinista. A massa era diretamente proporcional a uma potência do diâmetro das partículas e as constantes de proporcionalidade eram avaliadas, experimentalmente, para cada tipo de material. 


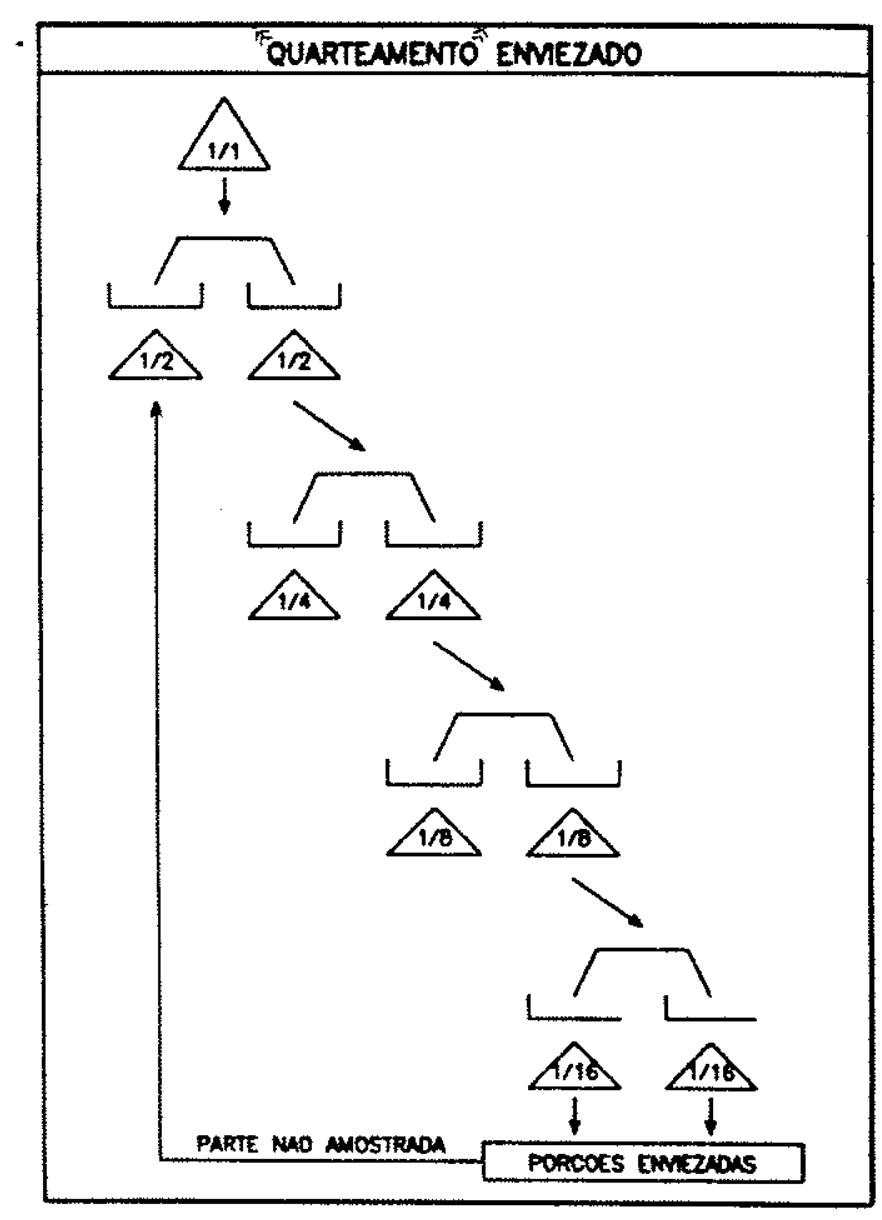

Figura 18. Esquena de subdivisto enviesada, porén é a foraa couvente espregada, principalente conhecinento (Yananoto, 1993).

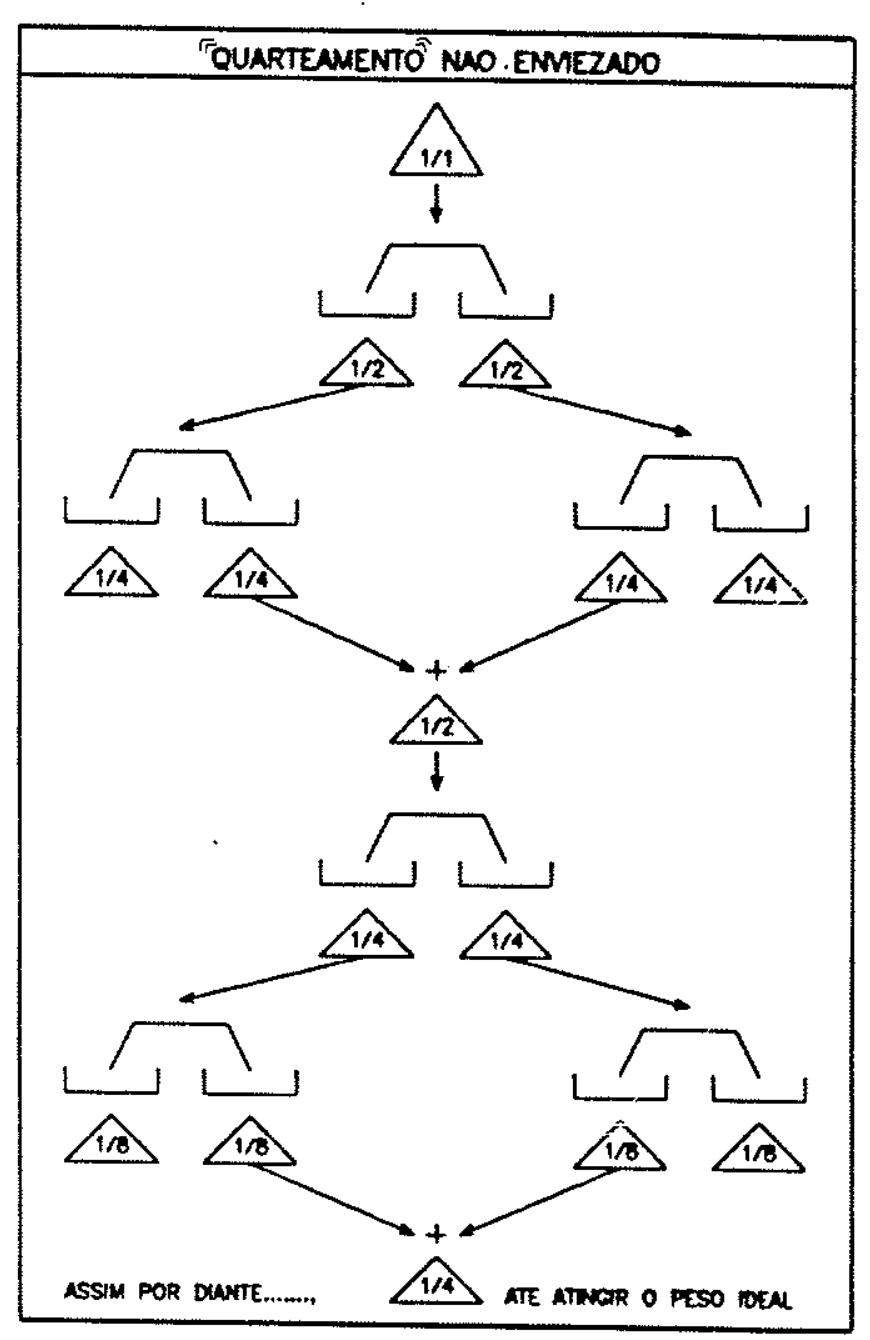

Figura 19. Esquewa de subdivisto correta, onde a porcto quarteada apresenta o elemento con a esesa probabilidade do restante (Yamanoto, 1993).

щ 
Pierre Gy (1953), considerando as hipóteses probabilísticas da amostragem, enunciou a sua equação básica de amostragem na qual, pela primeira vez, incluí a relação entre a massa e o diâmetro das partículas, e a variância relativa do erro de amostragem para cada estágio do processo de redução da amostra. Usando essa fórmula pode-se:

a - calcular o erro/variância para cada tamanho de amostra dividida da original, ou

b - calcular qual o tamanho da subamostra que seria usada para se obter uma determinada variância a nível de confiança de 95\%. Segundo Ottley (1966), a equação de Gy é expressa por:

$$
s^{2}=d^{3} \cdot f \cdot g \cdot l \cdot m\left(\frac{1}{M_{1}}-\frac{1}{M_{2}}\right)
$$

onde " $\mathrm{M}_{2}$ " é o peso da amostra inicial (gramas), "M 1 " é o peso da subamostra (gramas), "d" é a dimensão (cm) da maior partícula na amostra inicial (o tamanho da malha que passa 90-95\% de material), " $\mathrm{f}$ " é o fator de forma, igual a $0,5 \mathrm{em}$ todos os casos práticos, exceto para ouro, que é igual a 0,2 (ele tem valor máximo igual a 1,0 para partículas na forma de cubos perfeitos), "g" é o fator de distribuição granulométrica, geralmente igual a 0,25 , "l" é o fator de liberação, com valores entre 0 (zero) e 1 (um), sendo 0 para materiais perfeitamente homogêneos e 1 para materiais perfeitamente heterogêneos - na prática, o valor de " $\mathrm{L}$ " é calculado como sendo a raiz quadrada da razão do tamanho de liberação " $L$ ", obtido na prática, e o tamanho "d" da maior partícula, ou seja,

$L=\left(\frac{L}{d}\right)^{\frac{1}{2}}$ quando $L / \mathrm{d}>1$, "L" é tido como 1,0

onde "L" é o tamanho de liberação definido na prática como: o diâmetro máximo da partícula que garante a liberação total do componente avaliado ( $\mathrm{L}$ é expresso em $\mathrm{cm}$ ) - , "m" = é o parâmetro de composição mineralógica - expresso em $\mathrm{g} / \mathrm{cm}^{3}$ - o qual pode ser calculado como:

$m=\frac{1-a}{a}[(1-a) \cdot r+a \cdot t]$ ou

$m=\frac{r}{a}$ para teores baixos;

onde " $\mathrm{r}$ " e " $\mathrm{t}$ " são, respectivamente, as densidades médias do mineral de minério e do mineral de ganga, "a" é concentração média do mineral (não do conteúdo metálico) de minério no material amostrado, "d" é a dimensão em $\mathrm{cm}$ da maior partícula do 
material amostrado (amostra inicial), "s" é a medida do erro fundamental cometido na amostragem, ou o erro que pode ser tolerado no resultado analítico da amostra, quando uma amostra de " $\mathrm{M}_{1}$ " gramas é coletada de uma amostra de " $\mathrm{M}_{2}$ " gramas caracterizada pelos parâmetros "d", "f", "g", "l" e "m".

O fator de liberação tem sido determinado a partir de vários estudos práticos (Ottley, 1966), conforme a Tabela 3.

Tabela 3: Valores do fator de liberação l, en função da razão entre o diâmetro da maior partícula na amostra (d) e o diâmetro de liberação (L) do minério (Onley, 1966).

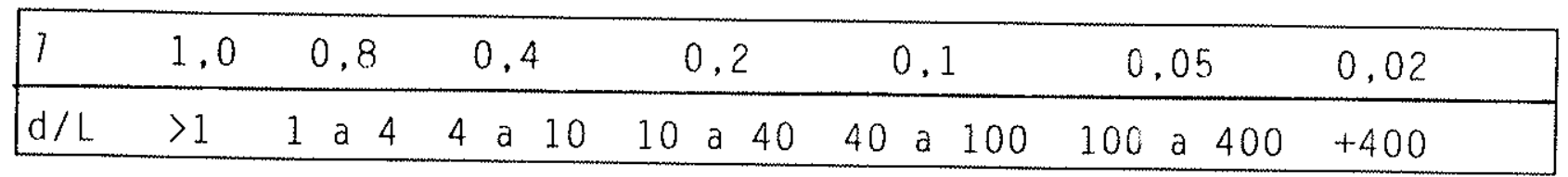

Uma versão simplificada da fórmula de Gy, apresentada anteriormente, pode ser expressa como segue:

$$
s^{2}=\frac{C \cdot d^{3}}{M}
$$

onde "s 2 " é a variância relativa, ou o erro exposto na utilização do peso de uma amostra "M", para avaliar uma amostra volumétrica cujo maior fragmento de minério tem dimensão "d" $(\mathrm{cm}) . " \mathrm{C}$ " representa uma combinação de fatores $-\mathrm{C}=f \times g \times l \times \mathrm{m}$ - conforme visto acima.

$O$ erro aumenta se a quantidade de minerais econômicos nos fragmentos de minério diminuir em relação à ganga, e também se houver aumento na liberação de minerais ecomômicos a partir da ganga; a pior situação ocorrerá quando os fragmentos consistem da própria ganga ou do mineral de minério. $O$ erro também diminui quando a distribuição do tamanho dos grãos dentro dos fragmentos aumenta, na tentativa de se uniformizar o tamanho dos grãos com os minerais de minério. A fórmula simplificada de Gy indica também que o erro relativo é proporcional ao volume dos maiores fragmentos e inversamente proporcional ao peso da amostra.

A equação de Gy, pode ser utilizada para:

- cálculo do peso da amostra a ser quarteada da massa inicial, conhecido o teor aproximado, a dimensão da maior partícula, a exatidão requerida, as densidades do minério e ganga e diâmetro de liberação do mineral de interesse: 


$$
M=\frac{C \cdot d^{3}}{s^{2}}
$$

- determinação do erro fundamental de amostragem quando determinada massa é analisada, conhecendo-se: o diâmetro da maior partícula, o diâmetro de liberação, teor do minério e densidades:

$$
s^{2}=\frac{C \cdot d^{3}}{M}
$$

- cálculo do diâmetro para o qual o material deve ser moído, conhecida a massa da amostra, o erro de amostragem e o valor de " $\mathrm{C}$ " (de outras jazidas semelhantes):

$$
t^{3}=\frac{M \cdot s^{2}}{C}
$$

\subsection{Erros de amostragem}

"Qualquer amostragem - até mesmo a mais simples - comporta uma série de erros possíveis, alguns dos quais relacionados com a estrutura do minério, com sua distribuição e sua textura, outros decorrentes das técnicas usadas na amostragem, ou do modo como as técnicas são aplicadas, ou dos instrumentos de amostragem. (Gy,1968)."

Este problema, infelizmente, não termina com a retirada da amostra mas continua através da preparação, subdivisão e estágios de análise em laboratório, cada um dos quais é passível de erros que podem afetar a precisão da amostra ou influenciar sua exatidão.

Segundo Miesh (1967), o erro de amostragem representa a diferença composicional entre a amostra de rocha e a parte do corpo dela com que se espera representá-la. Essa diferença de volumes amostrados implica, por outro lado, a representatividade da amostragem (relação volume $\mathrm{x}$ variância $=$ constante) e o erro de estimativa decorrente da extensão do teor da amostra, de pequeno volume, para um bloco do minério, de volume muito maior.

a- Erros de preparação. A preparação de uma amostra compreende uma série de operações não seletivas tais como redução da granulometria, mistura, homogeneização e subdivisão, visto que a amostra geológica é geralmente muito grande para análise. Durante essa etapa o operador incorre no erro de preparação - que é a soma de vários erros - erros produzidos pela:

- perda de partículas da amostra (p.ex.: perda de finos na poeira, perda de material retido na preparação ou no circuito de amostragem, perda de frações finas) 
- contaminação, isto é: adicão de uma porção de măterial estranho à amostra, diminuindo-se ou aumentando-se o teor do elemento de interesse, conforme esse material esteja ou não mineralizado (p.ex.: contaminação por poeira, por material presente na amostra e nos equipamentos, por salgamento);

- alteração do interesse a ser medido, como consequencia dos erros na alteração da composição química (p.ex.: alteração de sulfetos, fixação de água ou dióxido de carbono por óxidos ou minerais calcinados) ou da composição física;

- mistura não intencional do operador devido à ignorância, negligência, falta de experiência, etc deste (p.ex.: despejo da amostra, perda de frações, mistura de subamostras provenientes de diferentes amostras);

- alteração intencional do parâmetro de interesse (p.ex.: por sabotagem ou fraude).

$\mathrm{Na}$ impossibilidade de avaliar experimentalmente esses erros de preparação, alguns procedimentos rotineiros permitem sejam afastados os mais freqüentes ou pelo menos minimizados.

b- Erro Total de Amostragem. Representa a soma dos erros decorrentes das etapas de amostragem e da preparação da amostra primária. Esse erro pode ser calculado numericamente: faz-se a diferença entre o valor da média real $\mu$ (média populacional) de um parâmetro de interesse do universo a ser amostrado e o valor da média " $\bar{X}$ " (média amostral), deste mesmo parâmetro de interesse em uma amostra.

A distribuição das médias " $\bar{X} "$ tende a uma distribuição normal com média $\mu$ e desviopadrão $\sigma / \sqrt{n}$, à medida que aumenta o tamanho da amostra, tal como se enuncia no Teorema do Limite Central (Barnes, 1980) - "se amostras aleatórias de tamanho fixo são retiradas de uma população cuja distribuição teórica é arbitrária, mas com média e variância finitas, a distribuição das amostras tende cada vez mais a uma distribuição normal com média $\mu$ e variância $\sigma^{2} / n$, à proporção que as amostras aumentem de tamanho."

c- Erros Analíticos. São decorrentes da diferença entre o resultado da análise e a concentração na amostra original. Segundo Waeny (1979), os erros analíticos podem ser sistemáticos ou aleatórios.

Os erros analíticos sistemáticos são aqueles que afetam as análises de maneira uniforme e decorrem da imperfeição dos instrumentos, da incorreção da técnica analítica, da impureza dos reagentes e de outros pequenos problemas, todos passíveis de controle ou atenuação.

Os erros analíticos aleatórios são os de causa desconhecida, mas que podem ser localizados quando da análise periódica de um grupo de amostras. 
Independentemente do tipo de erro e do método analitico utilizado, existem limites de sensibilidade, além dos quais a determinação dos valores de concentração não é efetiva.

Controladas essas fontes de erros ligadas à amostragem, a variabilidade restante é atribuida à variabilidade natural dos depósitos minerais, principal fonte dos erros em amostragem.

A variabilidade natural dos depósitos minerais se mede pelo coeficiente de variação, que é uma porcentagem do desvio-padrão em relação à média, conforme a expressão:

$C V=\frac{S}{\bar{X}}$

onde " $\bar{X}$ " é a média das observações, "S" é o desvio-padrão.

Kreiter (1968) apresenta, conforme Quadro Il, a classificação dos depósitos minerais, segundo os valores de coeficiente de variação para espessura, teor e reserva. 


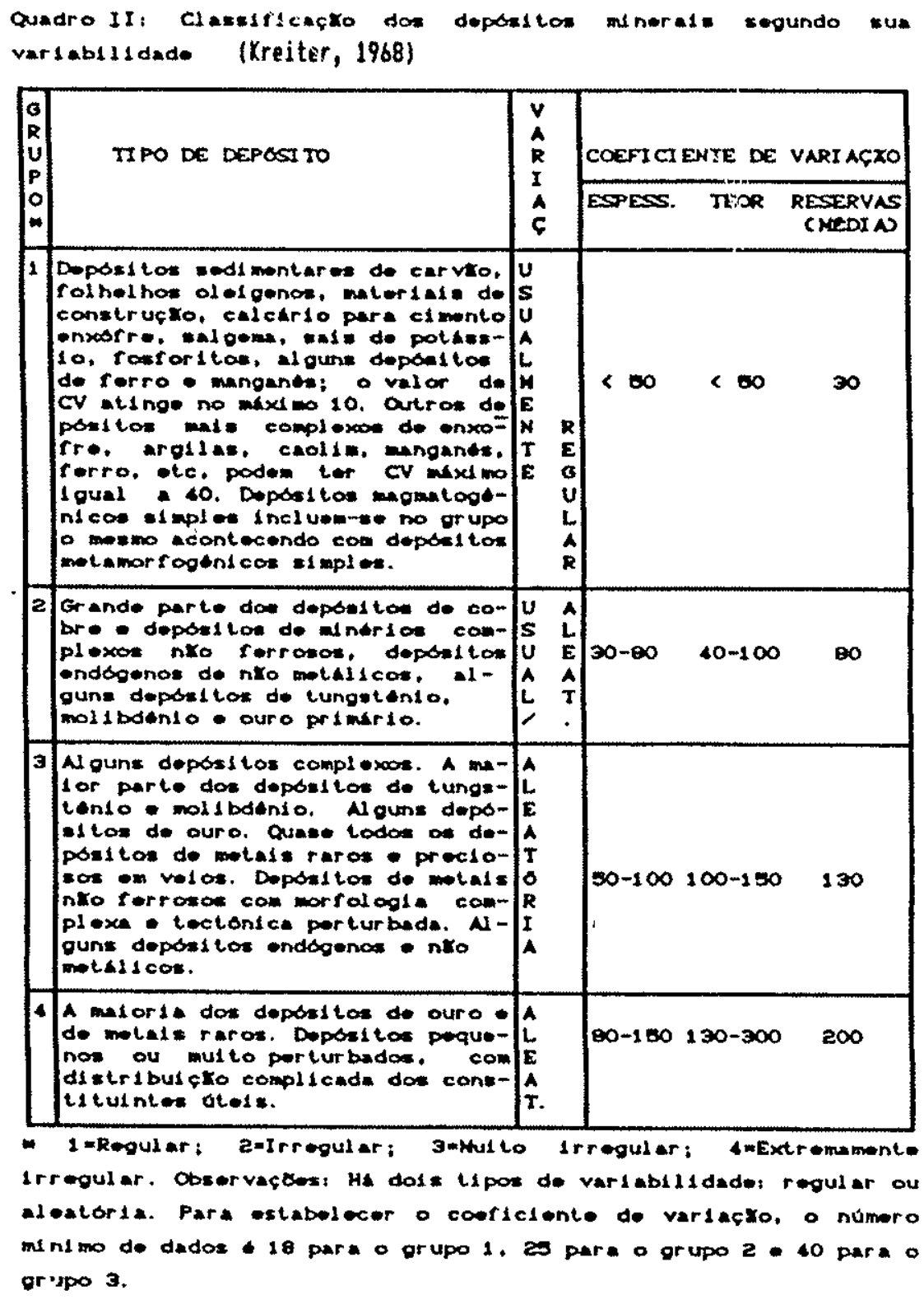

Assim, quanto maior o erro natural ou a variabilidade natural do depósito mineral, maior será o esforço de amostragem para diminuir os erros de amostragem. 


\section{CAPítulo 6 \\ INVENTÁRIO DOS DADOS DA PESQUISA MINERAL}

Neste capítulo apresentamos o inventário, segundo os parâmetros recomendados por Handley et alii (1987), dos dados obtidos da pesquisa mineral realizada no Pegmatito Xupé no tocante à mineralização de Sn e Ta. Estes parâmetros, juntamente com as informações obtidas no Pegmatito Xupé, encontram-se descritos a seguir.

\subsection{Densidade de informações}

O Pegmatito Xupé foi pesquisado em 15 furos, feitos por sonda rotativa a diamante totalizando $1423 \mathrm{~m}$ (com 177,49 $\mathrm{m}$ de rocha analisada) - complementado por $317 \mathrm{~m}$ lineares de escavações subterrâneas, das quais $160 \mathrm{~m}$ ao longo do corpo pegmatítico.

Executadas segundo um espaçamento médio de 40 a $70 \mathrm{~m}$, as sondagens estão registradas no Mapa Geológico do Xupé Sul da Figura 8 e na relação dos furos de sondagem apresentada na Tabela 4. Uma relação de 203 amostras analisadas, 816 determinações analíticas e a porcentagem de testemunho - com diâmetro $\mathrm{BX}$ ou NX - recuperado fazem parte da listagem na Tabela 5.

Os resultados de teores de $\mathrm{Sn}$ e $\mathrm{Ta}_{2} \mathrm{O}_{5}$ obtidos nos furos de sondagem mostraram valores próximos a uma média constante, como no caso dos furos XS-01 (intervalo de 39,93 até 48,55 m); furo XS-05 (intervalo de 44,24 até 52,60 m); furo XS-10 (intervalo de 36,06 até 44,35 m), mas, na grande maioria dos furos, valores abaixo de teores esperados (teor de corte $=500 \mathrm{gSn} / \mathrm{t}$, Fontanelli, 1982) e praticados no garimpo (teor recuperado de até $20 \mathrm{Kg} \mathrm{SnO}_{2} / \mathrm{t}$ em corpos individualizados). Somente as sondagens XS-3 (intervalo 43,52 até 46,65 m); XS-06 (intervalo de 46,50 até $47,50 \mathrm{~m}$ ); XS-10 (intervalo de 34,62 até 36,06 m) e XS-11 (intervalo de 40,39 até $41,39 \mathrm{~m}$ ) apresentaram teores elevados.

Em face desses resultados obtidos na sondagem, que foram julgados incompativeis com os conhecidos de catas garimpeiras no Pegmatito Xupé e de outras cavas amostradas nas porções $N$ e $\mathrm{S}$ desse garimpo, a Empresa optou pelo método de amostragem volumétrica mediante escavações subterrâneas, pelas quais também se pudesse obter parâmetros básicos da caracterização tecnológica do minério, teor médio do depósito, densidade, taxas de recuperação dos minerais, seleção e dimensionamento de equipamentos para futura lavra, limite inferior do corpo de minério, etc. 
Tabela 4: Relação dos furos de sondagem na região do Xupé

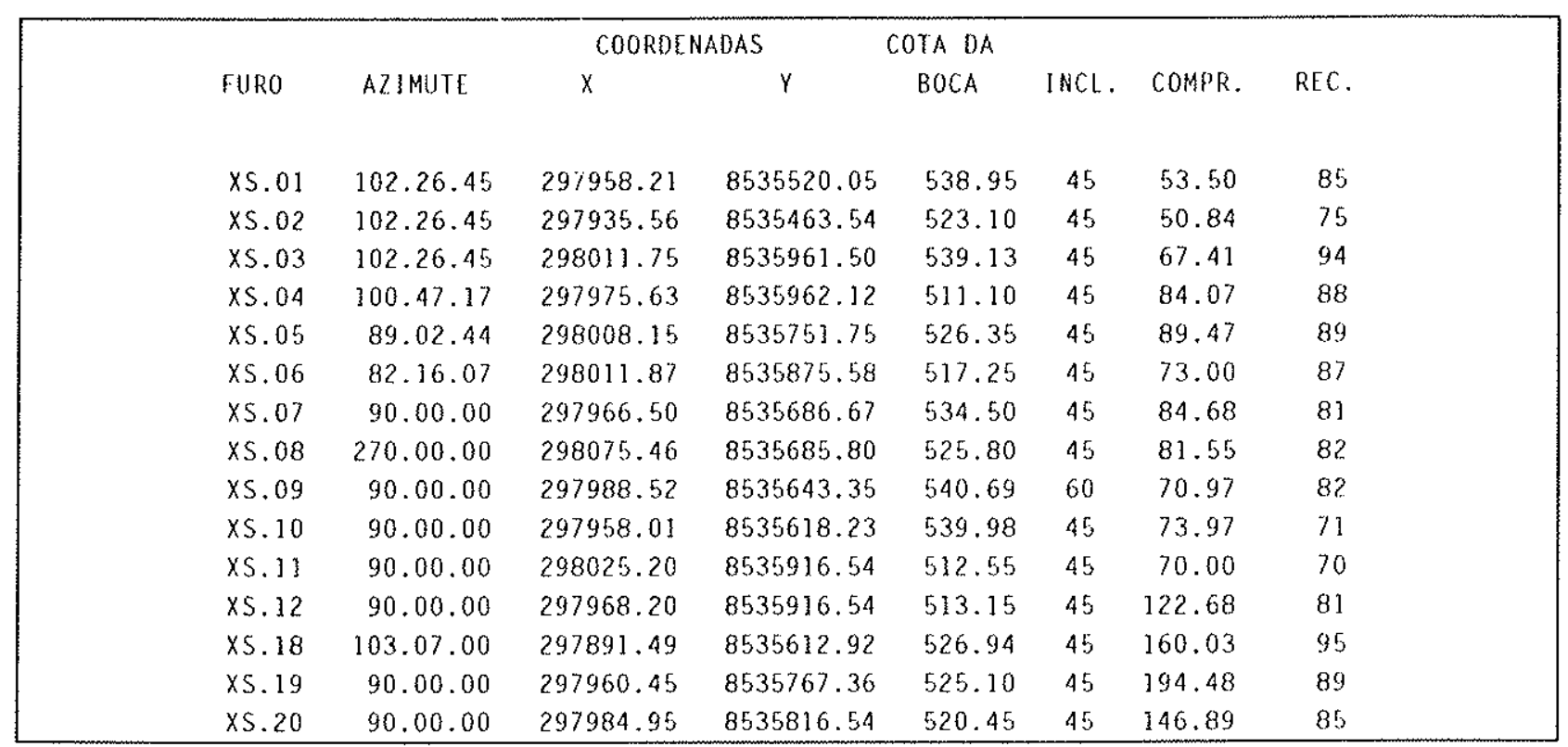

Tabela 5: Resultados analíticos dos testemunhos de sondagem analisados no Depósito Xupé.

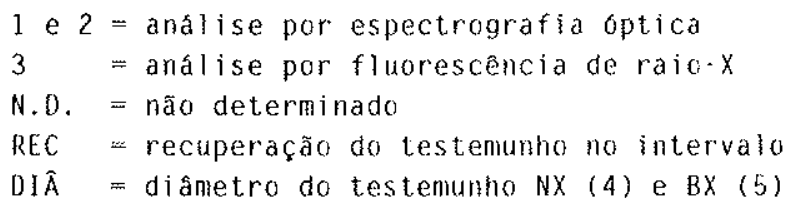

FURO FSXS-1

RESULTADOS ANALITICOS

\begin{tabular}{|c|c|c|c|c|c|c|c|c|c|c|}
\hline \multicolumn{2}{|c|}{ INT. ANAL. } & $\operatorname{sn}(1)$ & $\sin (2)$ & $\operatorname{Sn}(3)$ & $W(1)$ & $\mathrm{Cu}(\mathrm{l})$ & As (1) & $M b(1)$ & REC & $0 \backslash \hat{A}$ \\
\hline DE & ATE & & & & & & & & & \\
\hline 11.43 & 11.83 & .5 & -5 & -5 & -30 & & & $\cdot 20$ & 100 & 4 \\
\hline 13.50 & 14.37 & -5 & -5 & -5 & -30 & & & -20 & 100 & 4 \\
\hline 14.62 & 15.12 & .5 & .5 & -5 & -30 & & & -20 & 90 & 4 \\
\hline 16.76 & 17.39 & -5 & -5 & -5 & -30 & & & -20 & 100 & 4 \\
\hline 22.97 & 23.29 & $\cdot 5$ & -5 & -5 & -30 & & & -20 & 100 & 4 \\
\hline 24.56 & 25.26 & -5 & $\cdot 5$ & -5 & 30 & & & -20 & 100 & 4 \\
\hline 28.76 & 29.66 & .5 & -5 & -5 & -30 & & & .20 & 88 & 4 \\
\hline 33.73 & 34.31 & -5 & 6 & -5 & 30 & & & -20 & 94 & 4 \\
\hline 38.00 & 38.50 & -5 & & & -30 & 106 & 82 & -20 & 100 & 4 \\
\hline 39.93 & 40.38 & 495 & $48 ?$ & 620 & -30 & & & -20 & 88 & 4 \\
\hline 44.58 & 45.48 & 420 & 550 & 500 & -30 & & & -20 & 51 & 4 \\
\hline 45.48 & 45.73 & 84 & 82 & 90 & -30 & & & .20 & 100 & 4 \\
\hline 46.25 & 46.75 & 7 & 10 & 10 & -30 & & & .20 & 92 & 4 \\
\hline 48.05 & 48.55 & 645 & 670 & 420 & $\cdot 30$ & & & -20 & 74 & 4 \\
\hline 51.10 & 53.50 & .5 & & & -30 & 38 & 44 & & 81 & $A$ \\
\hline
\end{tabular}


FURO FSX-2

RESULTADOS ANALITICOS

\begin{tabular}{|c|c|c|c|c|c|c|c|c|c|c|}
\hline \multicolumn{2}{|c|}{ INT.ANAL. } & $\sin (1)$ & $\operatorname{sn}(2)$ & $\sin (3)$ & $w(1)$ & $\mathrm{Cu}(1)$ & As (1) & $N b(1)$ & $\mathrm{REC}$ & $01 \bar{A}$ \\
\hline$D E$ & ATÉ & & & & & & & & & \\
\hline 01.56 & 02.26 & 52 & 62 & 60 & -30 & & & -20 & 100 & 4 \\
\hline 02.63 & 02.99 & 52 & & & -30 & -5 & $\cdot 1$ & & 100 & 4 \\
\hline 04.49 & 04.82 & 12 & 18 & 20 & -30 & & & -20 & 100 & 4 \\
\hline 05.35 & 05.58 & -5 & 6 & .5 & -30 & & & -20 & 87 & 4 \\
\hline 08.97 & 10.52 & -5 & & & -30 & -5 & -1 & & 75 & 4 \\
\hline 11.43 & 11.83 & 12 & & & -30 & & & & 48 & 4 \\
\hline 13.50 & 14.37 & .5 & & & -30 & & & & 64 & 4 \\
\hline 20.11 & 20.54 & -5 & & & -30 & -5 & -1 & & 100 & 5 \\
\hline 20.54 & 21.08 & 20 & & & -30 & 40 & 7 & & 100 & 5 \\
\hline 21.68 & 23.61 & -5 & -5 & 16 & -30 & & & -20 & 73 & 5 \\
\hline 36.17 & 37.00 & -5 & 7 & -5 & $\cdot 30$ & & & -20 & 32 & 5 \\
\hline 38.00 & 38.50 & -5 & & & $\cdot 30$ & & & & 57 & 5 \\
\hline 38.82 & 39.74 & -5 & & & -30 & -5 & 2 & & 92 & 5 \\
\hline 39.93 & 40.38 & -5 & & & -30 & & & & 84 & 5 \\
\hline 40.71 & 41.27 & 22 & & & -30 & 9 & 48 & & 79 & 5 \\
\hline 44.94 & 45.54 & -5 & & & $\cdot 30$ & 32 & 32 & & 67 & 5 \\
\hline 48.82 & 49.40 & .5 & & & -30 & -5 & -1 & & 82 & 5 \\
\hline
\end{tabular}

FURO FSXS. 3

RESULTADOS ANALITICOS

\begin{tabular}{|c|c|c|c|c|c|c|c|c|c|c|c|}
\hline \multicolumn{2}{|c|}{ INT. ANAL. } & $\sin (1)$ & $\sin (2)$ & $\sin (3)$ & $W(1)$ & $\mathrm{Cu}(1) \operatorname{AS}(1)$ & $\mathrm{Nb}_{2} \mathrm{O}_{5}$ & Be & $\mathrm{Ta}_{2} \mathrm{O}_{5}$ & REC & $0 I \hat{A}$ \\
\hline$D E$ & ATÉ & & & & & & & & & & \\
\hline 00.00 & 00.52 & -5 & -5 & -5 & -30 & & & & & 100 & 4 \\
\hline 00.52 & 00.96 & -5 & -5 & .5 & -30 & & & & & 100 & 4 \\
\hline 02.57 & 03.33 & -5 & -5 & -5 & -30 & & & & & 89 & 4 \\
\hline 06.35 & 06.60 & 8 & .5 & -5 & -30 & & & & & 300 & 4 \\
\hline 07.98 & 08.39 & 5 & $\cdot 5$ & -5 & -30 & & & & & 41 & 4 \\
\hline 09.65 & 10.25 & -5 & -5 & -5 & -30 & & & & & 100 & 4 \\
\hline 10.89 & 11.50 & -5 & -5 & -5 & -30 & & & & & 100 & 4 \\
\hline 12.00 & 12.50 & 23 & 15 & 45 & -30 & & & & & 88 & 4 \\
\hline 13.96 & 14.78 & 20 & 14 & & -30 & & & & & 89 & 4 \\
\hline 15.52 & 16.01 & 8 & -5 & -5 & $\cdot 30$ & & & & & 52 & 4 \\
\hline 20.26 & 20.91 & 39 & 40 & 70 & -30 & & & & & 83 & 4 \\
\hline 22.36 & 22.87 & 32 & 19 & & $\cdot 30$ & & & & & 100 & 4 \\
\hline 23.43 & 24.43 & 76 & 61 & 138 & -30 & & & & & 100 & 4 \\
\hline 26.06 & 27.03 & 25 & 8 & & -30 & & & & & 89 & 4 \\
\hline 27.78 & 28.58 & 30 & & & & & $<100$ & 7 & $<100$ & 100 & 4 \\
\hline 28.58 & 29.17 & 30 & -5 & -5 & $\cdot 30$ & & $<100$ & 7 & $<100$ & 100 & 4 \\
\hline 29.17 & 29.90 & 20 & & & & & $<300$ & 7 & $<100$ & 300 & 4 \\
\hline 29.90 & 31.48 & 50 & & & & & $<100$ & 10 & $<100$ & 100 & 4 \\
\hline 31.48 & 33.03 & 12 & -5 & -5 & -30 & & $<100$ & 20 & $<100$ & 100 & 4 \\
\hline 33.03 & 34.57 & 70 & .5 & -5 & -30 & & $<100$ & 15 & $<100$ & 92 & 4 \\
\hline 34.57 & 35.77 & 30 & -5 & .5 & -30 & & $<100$ & 7 & $<100$ & 95 & 4 \\
\hline 36.57 & 37.58 & 70 & & & & & $<100$ & 10 & $<100$ & 91 & 4 \\
\hline 37.58 & 38.08 & 210 & 184 & 390 & 30 & & $<100$ & 10 & $<100$ & 82 & 4 \\
\hline 38.08 & 38.73 & 165 & & & & & $<100$ & 10 & $<100$ & 78 & 4 \\
\hline 38.73 & 39.73 & 20 & & & & & $<100$ & 5 & $<100$ & 93 & 4 \\
\hline 39.73 & 40.53 & 20 & & & & & $<100$ & 7 & $<100$ & 85 & 4 \\
\hline 40.53 & $4] .25$ & 20 & & & & & $\angle 100$ & 5 & $<100$ & 78 & 4 \\
\hline
\end{tabular}


Tabela 5: continuação

\begin{tabular}{|c|c|c|c|c|c|c|c|c|c|c|c|c|}
\hline 41.25 & 42.10 & 20 & 12 & & -30 & & & $<100$ & 5 & $<100$ & 94 & 4 \\
\hline 42.10 & 42.92 & 50 & & & & & & $<100$ & 5 & $<100$ & 88 & 4 \\
\hline 42.92 & 43.52 & 100 & & & & & & $<100$ & 7 & $<100$ & 80 & 4 \\
\hline 43.52 & 44.27 & 4560 & 5000 & 7200 & $\cdot 30$ & & & 110 & 10 & 395 & 83 & 4 \\
\hline 44.27 & 44.64 & 145 & & & & & & $<100$ & 7 & $<100$ & 84 & 4 \\
\hline 44.64 & 45.40 & 450 & 520 & 300 & -30 & & & $<100$ & 7 & $<100$ & 88 & 4 \\
\hline 45.80 & 46.65 & 1980 & 1755 & 1210 & -30 & & & & & & 85 & 4 \\
\hline 48.01 & 48.80 & -5 & .5 & -5 & -30 & & & & & & 79 & 4 \\
\hline 50.16 & 50.76 & & -5 & & -30 & -5 & 2 & & & & 73 & 4 \\
\hline 5$] .11$ & 52.02 & .5 & -5 & -5 & -30 & & & & & & 77 & 4 \\
\hline 52.72 & 53.41 & -5 & -5 & .5 & -30 & & & & & & 96 & 4 \\
\hline 58.89 & 59.74 & -5 & -5 & -5 & -30 & & & & & & 100 & 4 \\
\hline 65.53 & 66.95 & .5 & .5 & -5 & -30 & & & & & & 90 & 4 \\
\hline
\end{tabular}

FURO FSXS- 4

RESULTADOS ANALITICOS

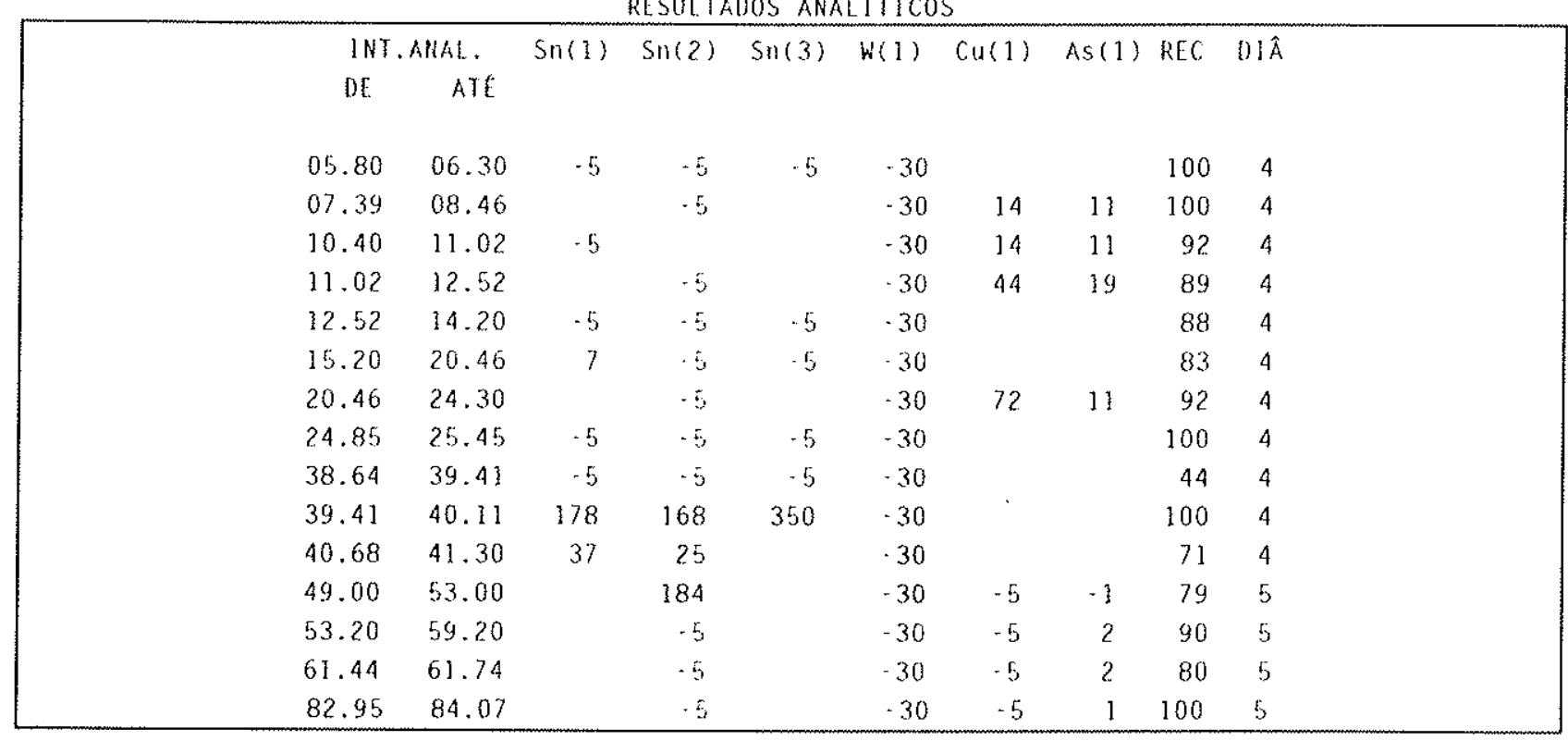

FIRO FSXS- 5

RESULTRDOS ANALITICOS

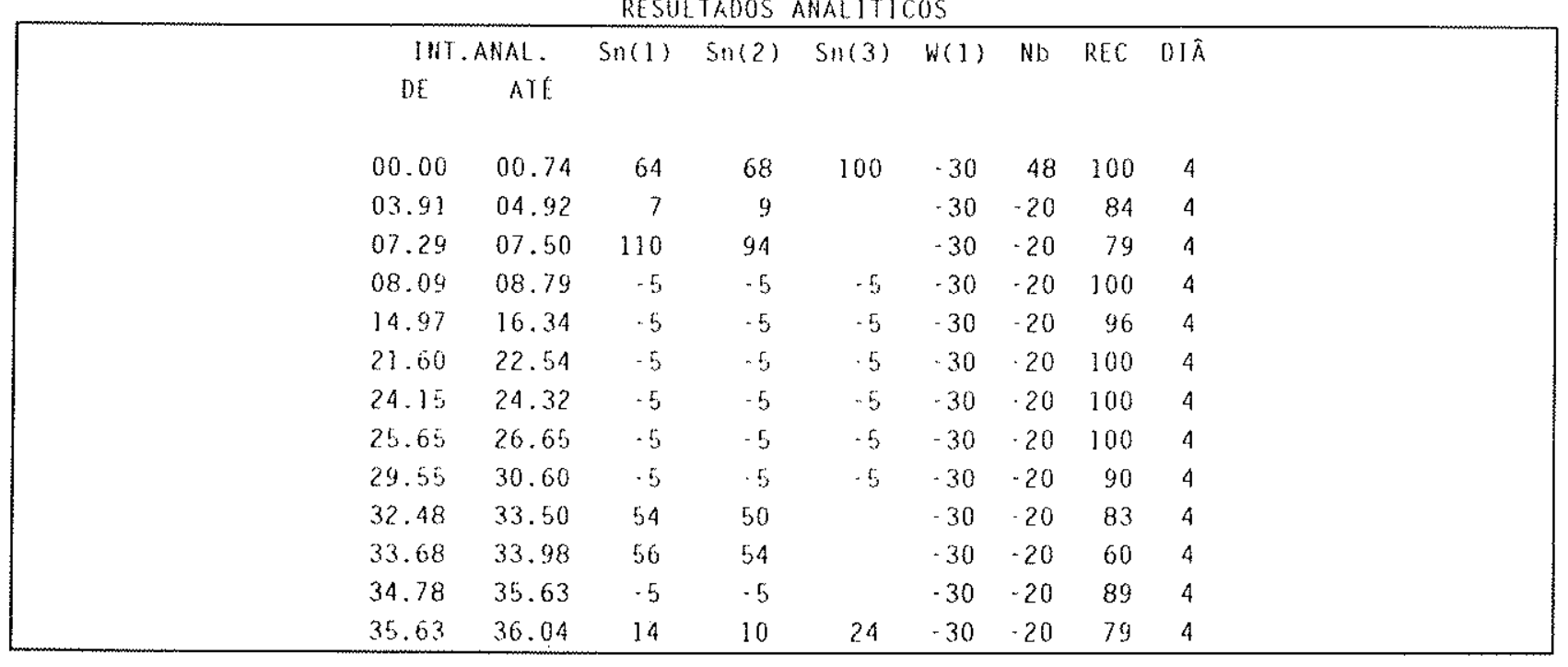


Tabela 5: continuação

\begin{tabular}{|rrrrrrrrrr|}
\hline 36.53 & 37.61 & 30 & 23 & & -30 & 20 & 100 & 4 \\
39.93 & 40.49 & 32 & 21 & & -30 & -20 & 86 & 4 & \\
41.35 & 41.80 & 50 & 35 & & -30 & -20 & 82 & 4 & \\
44.24 & 45.15 & 200 & 210 & 300 & -30 & 31 & 89 & 4 & \\
46.51 & 47.22 & 224 & 208 & 174 & -30 & -20 & 88 & 4 & \\
49.62 & 50.32 & 300 & 264 & 260 & -30 & -20 & 60 & 4 & \\
51.20 & 52.10 & 500 & 480 & 350 & -30 & -20 & 87 & 4 & \\
52.10 & 52.60 & 200 & 206 & 159 & -30 & -20 & 100 & 4 & \\
56.67 & 57.47 & 14 & 12 & & -30 & -20 & 100 & 4 & \\
63.71 & 64.65 & 8 & -5 & & -30 & -20 & 94 & 4 \\
68.64 & 69.71 & 6 & -5 & & -30 & -20 & 87 & 4 \\
73.81 & 74.65 & -5 & -5 & -5 & -30 & -20 & 100 & 5 \\
77.40 & 78.20 & 6 & -5 & & -30 & -20 & 83 & 5 \\
79.50 & 80.02 & 6 & -5 & -5 & -30 & -20 & 54 & 5 \\
83.04 & 83.96 & -5 & -5 & & -30 & -20 & 100 & 5 \\
87.49 & 88.81 & 8 & -5 & & -30 & -20 & 100 & 5 \\
\hline
\end{tabular}

FURO FSXS- 6

RESULTADOS ANALITICOS

\begin{tabular}{|c|c|c|c|c|c|c|c|c|c|}
\hline \multicolumn{2}{|c|}{ INT. ANAL. } & $\sin (1)$ & $\operatorname{Sn}(2)$ & $\operatorname{Sn}(3)$ & $W(1)$ & $\mathrm{Cu}(1)$ & As (1) & REC & DI $\hat{A}$ \\
\hline$D E$ & ATE & & & & & & & & \\
\hline 13.82 & 14.52 & .5 & & & -30 & 58 & 32 & 91 & 4 \\
\hline 16.85 & 17.00 & 8 & -5 & & -30 & & & 100 & 4 \\
\hline 17.41 & 18.00 & & .5 & & -30 & 28 & 7 & 93 & 4 \\
\hline 18.9$\}$ & 19.91 & -5 & -5 & -5 & -30 & & & 86 & 4 \\
\hline 20.45 & 21.23 & 10 & 8 & & -30 & & & 90 & 4 \\
\hline 21.10 & 22.00 & 6 & -5 & & -30 & & & 100 & 4 \\
\hline 22.00 & 22.50 & & -5 & & -30 & 34 & 7 & 100 & 4 \\
\hline 22.50 & 24.00 & & 52 & & -30 & 70 & 3 & 100 & 4 \\
\hline 25.52 & 26.13 & 63 & 60 & 82 & -30 & & & 69 & 4 \\
\hline 31.23 & 31.90 & 230 & 220 & & -30 & & & 85 & 4 \\
\hline 38.29 & 39.06 & 14 & 5 & & -30 & & & 88 & 4 \\
\hline 41.24 & 42.39 & 63 & 54 & & -30 & & & 89 & 4 \\
\hline 46.50 & 47.50 & 4590 & 4180 & 3420 & & & & 90 & 4 \\
\hline 48.33 & 49.30 & 520 & 430 & 570 & -30 & & & 100 & 4 \\
\hline 56.48 & 57.08 & & -5 & & -30 & 68 & 3 & 90 & 5 \\
\hline 72.02 & 73.00 & & 114 & & $\cdot 30$ & -5 & 134 & 100 & 5 \\
\hline
\end{tabular}

FSXS-07

RESULTADOS AWALITICOS

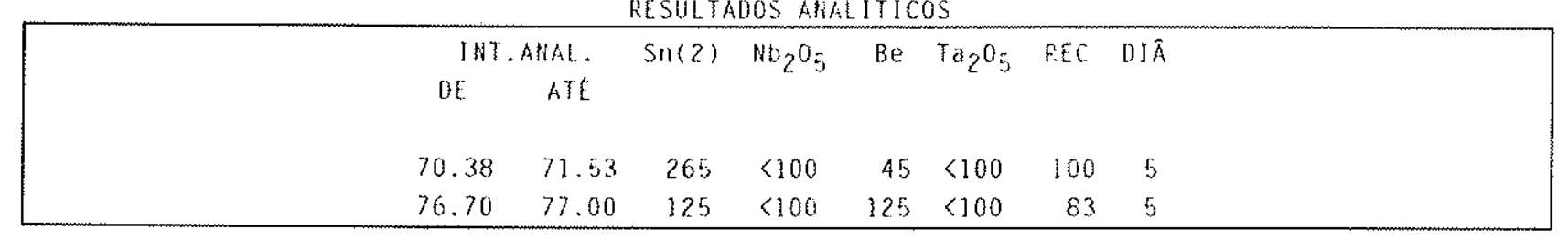


FSXS-08

RESULTAUOS ANALITICOS

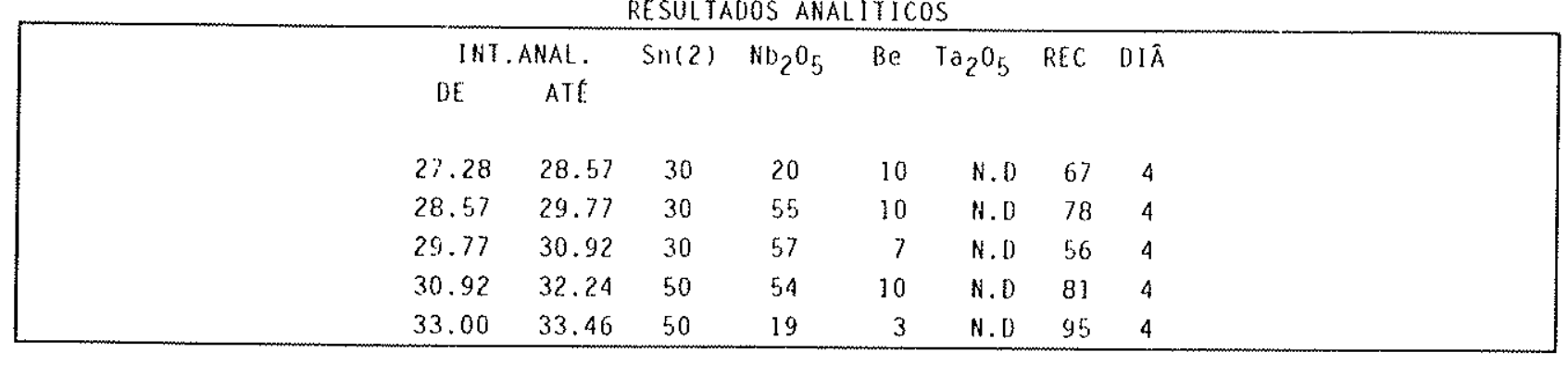

FSXS - 10

RESULTADOS ANALITICOS

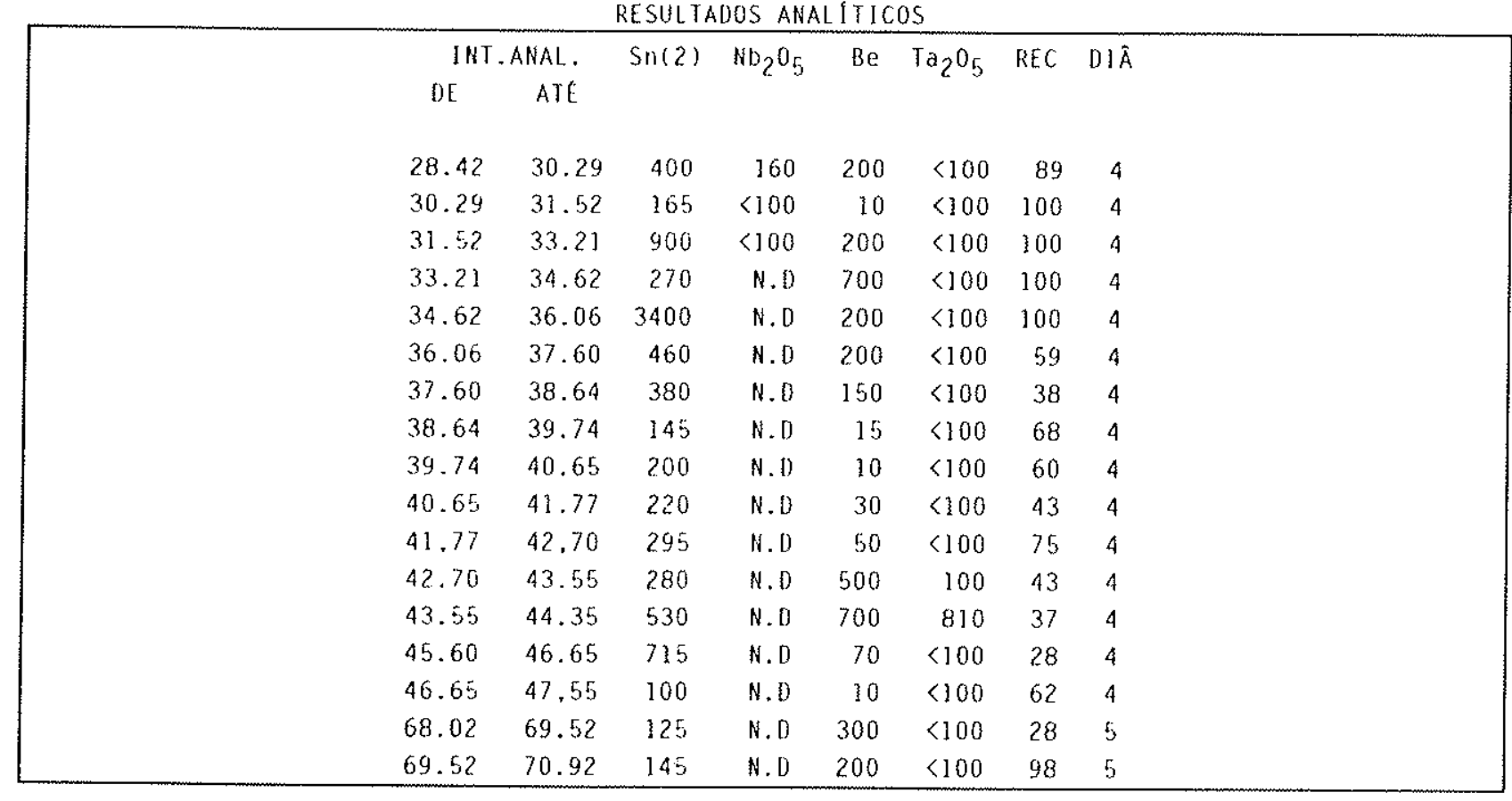

FSXS-11

RESULTAOOS ANALITICOS

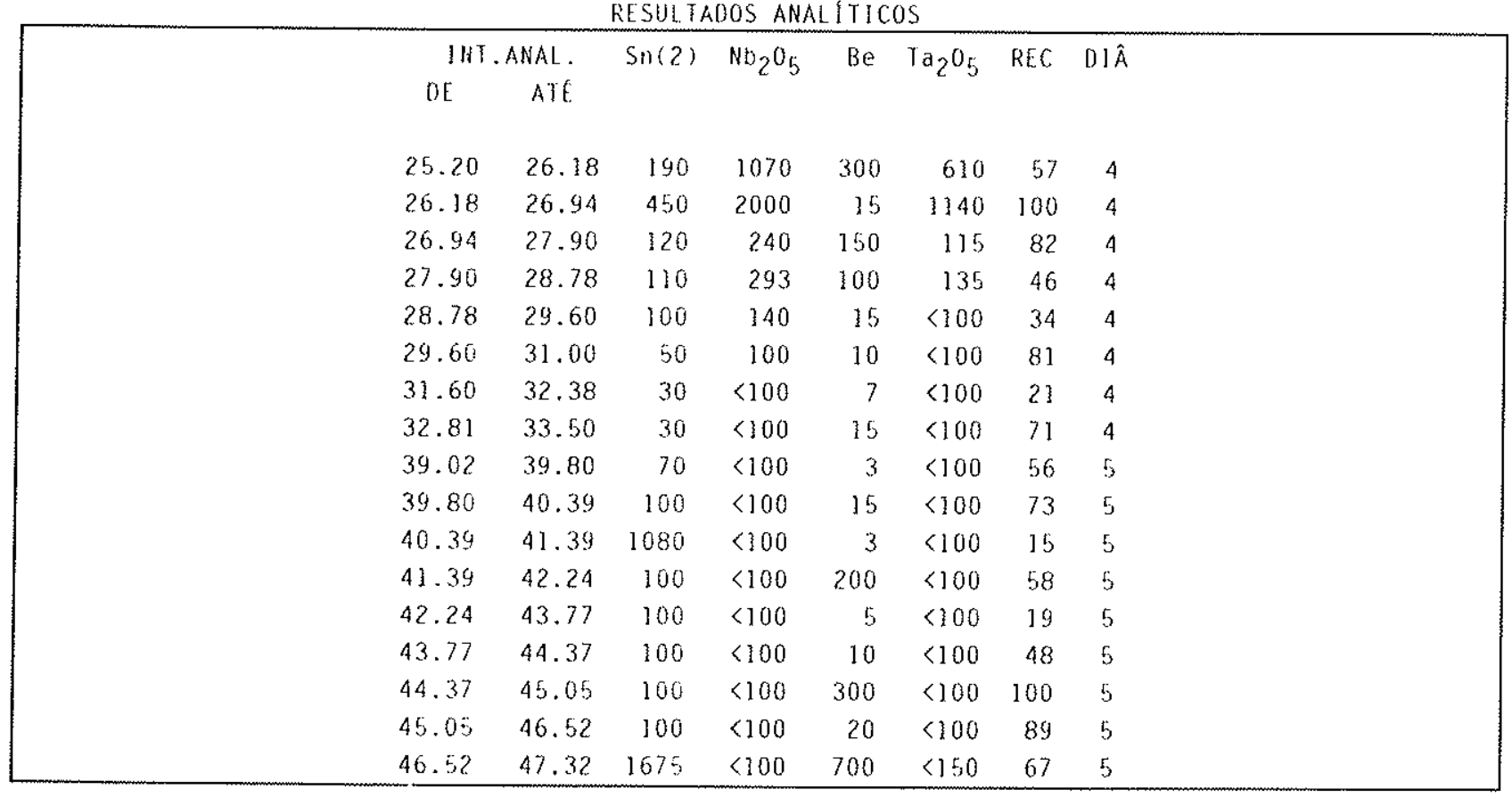


Tabela 5: continuação

\begin{tabular}{|rrrrrrrrr|}
\hline 47.32 & 48.27 & 600 & 100 & 500 & 100 & 100 & 5 \\
48.27 & 49.02 & 655 & $<100$ & 15 & $<100$ & 100 & 5 \\
49.02 & 49.92 & 105 & $<100$ & 7 & $<100$ & 100 & 5 \\
49.92 & 50.62 & 145 & 105 & 10 & $<100$ & 88 & 5 \\
50.62 & 51.12 & 160 & $<100$ & 500 & $<100$ & 100 & 5 & \\
51.12 & 52.52 & 255 & 120 & 15 & $<100$ & 100 & 5 & \\
52.52 & 52.92 & 100 & $<100$ & 200 & $<100$ & 100 & 5 \\
\hline
\end{tabular}

F $5 \times 5-12$

RESULTADOS ANALJTICOS

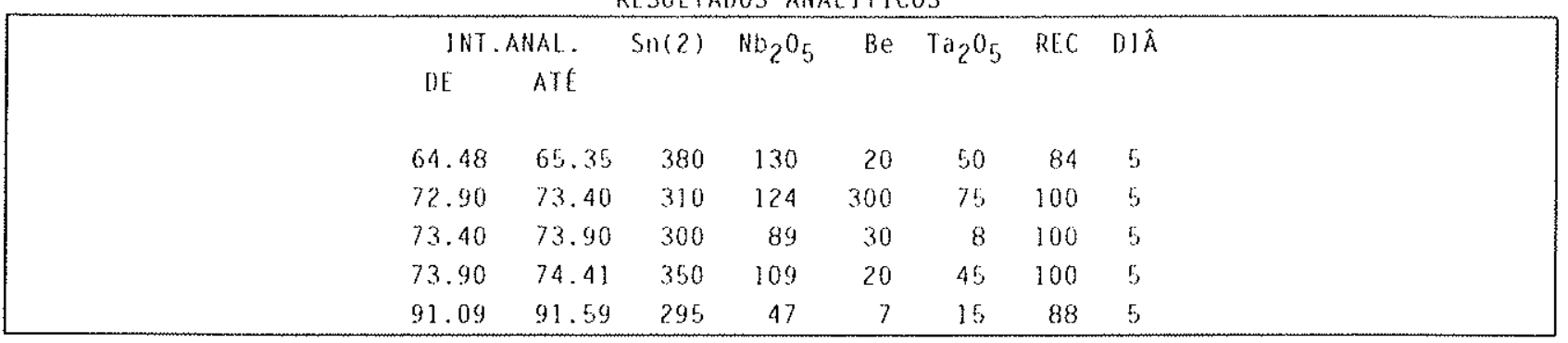

FSXS- 18

RESULTADOS ANAL!TICOS

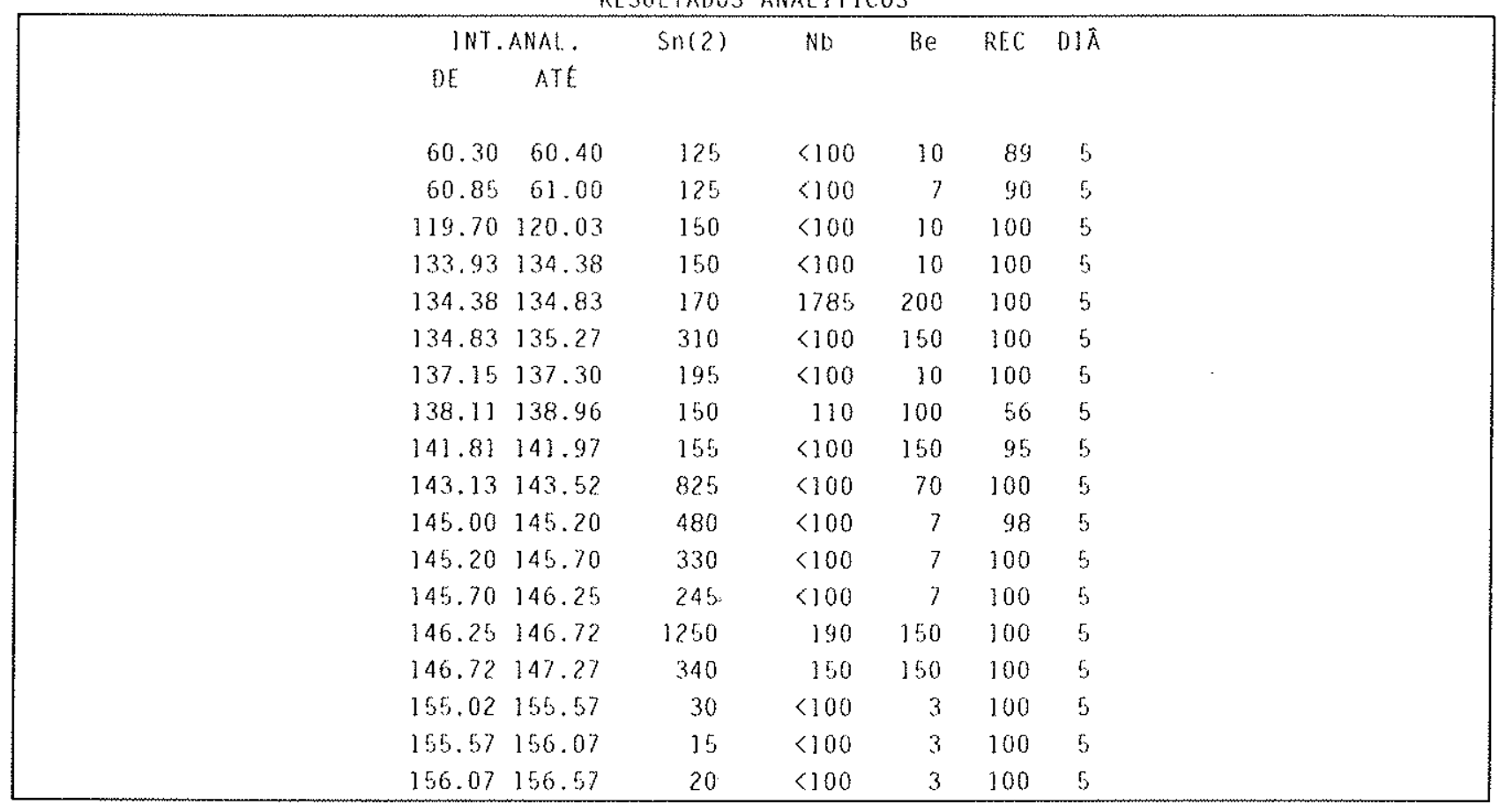


Tabela 6: Resuitados analíticos em $\mathrm{g} / \mathrm{m}^{3}$ de estanho e $\mathrm{Ta}_{2} \mathrm{O}_{5}$ dos avanços das galerias Xupé. $1=$ nome do avanço; $2=$ intervalo amostrado $(\mathrm{m}) ; 3=$ volume da amostra $\left(\mathrm{m}^{3}\right) ; 4=$ volume acumulado $\left(\mathrm{m}^{3}\right) ; 5=$ teor de estanho do avanço $\left(\mathrm{g} \mathrm{Sn} / \mathrm{m}^{3}\right) ; 6=$ teor de estanho acumulado $(\mathrm{g}$ $\left.\mathrm{Sn} / \mathrm{m}^{3}\right) ; 7=$ teor de $\mathrm{Ta}_{2} \mathrm{O}_{5}$ do avanço $\left(\mathrm{g} \mathrm{Ta}_{2} \mathrm{O}_{5} / \mathrm{m}^{3}\right) ; 8=$ teor de $\mathrm{Ta}_{2} \mathrm{O}_{5}$ acumulado $(\mathrm{g}$ $\left.\mathrm{Ta}_{2} \mathrm{O}_{5} / \mathrm{m}^{3}\right)$.

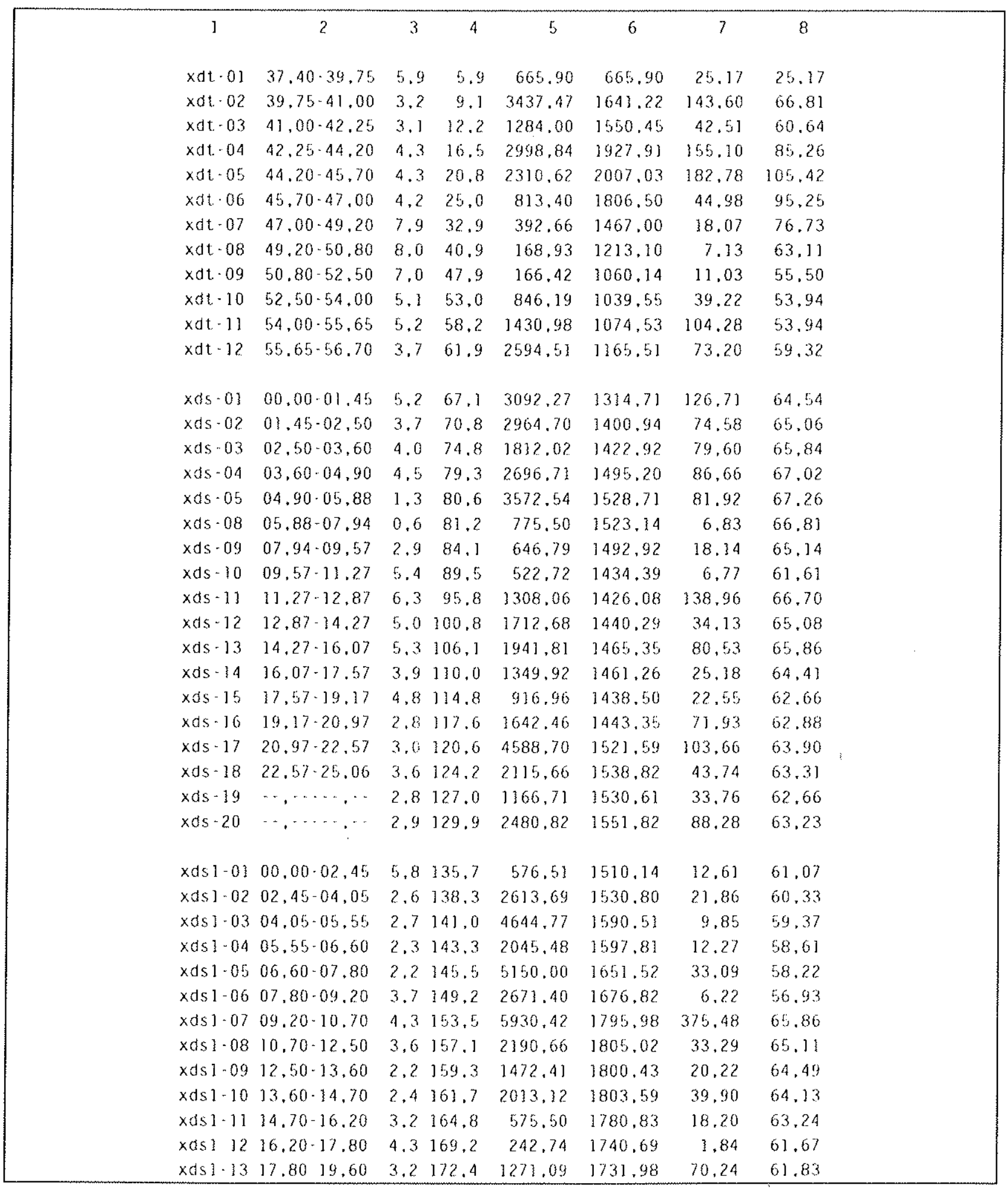


Tabela 6: continuação

\begin{tabular}{|c|c|c|c|c|c|c|}
\hline$x d s 1-14$ & $19.60 \cdot 21.20$ & $6.0 \quad 178.4$ & 740.90 & 1698.64 & 8.69 & 60.05 \\
\hline$x d s] 15$ & $21.20 \quad 22.70$ & $6,0 \quad 184.4$ & 1232.38 & 1683.47 & 68,02 & 60.31 \\
\hline$x d s\}-16$ & $22.70-2.4 .20$ & $6.0 \quad 190.4$ & 1493.00 & 1677.47 & 43,06 & 59.76 \\
\hline$x d s] \cdot 17$ & $24.20-25.00$ & $4.5 \quad 194.9$ & 462.75 & 1649.42 & 19.76 & 58.84 \\
\hline$x d s 1-18$ & $26,00 \cdot 27,30$ & $4.3 \quad 199.2$ & 792.07 & 1630.92 & 65.01 & 58.97 \\
\hline$x d s\} \cdot 19$ & $27.30 \cdot 28.50$ & $4.3 \quad 203.5$ & 699.56 & 1611.24 & 39.76 & 58.57 \\
\hline$x d s 1-20$ & $28.50-29.90$ & 4.3207 .8 & 413.16 & 1586.45 & 8.95 & 57.54 \\
\hline$x d n=01$ & $00.00-02.40$ & 4.9212 .7 & 2320.42 & 1603,34 & 15.92 & 56.58 \\
\hline$x d n \cdot 02$ & $02.40 \cdot 04.20$ & 3.7216 .4 & 1219.46 & 1596.77 & 14.12 & 55.85 \\
\hline$x d n-03$ & $04.20 \cdot 05.50$ & 2.7219 .1 & 1798.73 & 1599.26 & 10.56 & 55.30 \\
\hline$x(\ln \cdot 04$ & $05,50-07,00$ & 4.6223 .7 & 2354.94 & 1614,32 & 8.48 & 54,33 \\
\hline$x d n-0 s$ & $07.00 \cdot 08.50$ & 2.7226 .3 & 800.05 & 1605,08 & 5.42 & 53.75 \\
\hline$x d i 106$ & $08,50-10,40$ & 5.4231 .8 & 1102.43 & 1593.37 & 79.87 & 54.36 \\
\hline$x d n-07$ & $10.40 \cdot 11.90$ & 3.7235 .5 & 1975.82 & 1599.38 & 33.14 & 54.02 \\
\hline$x d n-08$ & $11,90 \cdot 13,40$ & 3.4238 .9 & 2296,85 & 1609.31 & 143.02 & 55.29 \\
\hline$x d n-09$ & $13,40-15,20$ & $3.2 \quad 242.1$ & 1406.78 & 3606.63 & 98.62 & 55.86 \\
\hline$x d n \cdot 10$ & $15.20-16.90$ & 3.0245 .1 & 1652.99 & 1607.20 & 38,89 & 55.66 \\
\hline$x d n-11$ & $16.90 \cdot 18,90$ & $5,2 \quad 250,3$ & 769.79 & 1589.80 & 7.68 & 54.66 \\
\hline$x d 1-12$ & $18.90-21.00$ & 4.5254 .8 & 622.52 & 1572.72 & 13.24 & 53.93 \\
\hline$x$ din- 13 & $21.00-22.70$ & 4.2259 .0 & 1210.96 & 1566,85 & 27.26 & 53.49 \\
\hline$x d n-14$ & $22.70 \cdot 24.40$ & 3.6262 .6 & 1288,48 & 1563,03 & 48,23 & 53.42 \\
\hline$x d n-15$ & $24.40-25.90$ & 2.7265 .3 & 3566.25 & 1583.42 & 48.64 & 53,37 \\
\hline$x d n \cdot 16$ & $25.90-27.70$ & $4.5 \quad 269.8$ & 1549.65 & 1582.85 & 25.04 & 52.90 \\
\hline$x d m-17$ & $27.70 \cdot 29.45$ & 5.4275 .2 & 2009.78 & 1591.24 & 44.49 & 52.74 \\
\hline$x d n-18$ & $29.45 \cdot 30.95$ & $3,8 \quad 279,0$ & 3120.61 & 1611,82 & 55.53 & 52.78 \\
\hline$x$ dn -19 & $30.95-32.95$ & $6,3285.3$ & 1136,32 & 1601,32 & 32.62 & 52.33 \\
\hline$x d n-20$ & $32.95 \cdot 34.00$ & 26.1311 .3 & 1649.09 & 1605.33 & 31.49 & 50.58 \\
\hline$x d n-21$ & $34.00 \cdot 35.00$ & 2.9314 .3 & 1907.31 & 1608,11 & 38.11 & 50.47 \\
\hline$x d n-22$ & $35.00 \cdot 36.00$ & $3,0317,3$ & 1046.44 & 1602.80 & 27.24 & 50.25 \\
\hline$x d n-23$ & $36.00-37.10$ & 3.2320 .5 & 660.21 & 1593.39 & 20.78 & 49.95 \\
\hline$x d m-24$ & $37.10 \cdot 38.70$ & $4,1324,6$ & 1342.65 & 1590.22 & 14.25 & 49.50 \\
\hline$x(n-25$ & $38.70-40.20$ & $4.6 \quad 329.2$ & 449.70 & 1574,28 & 17,42 & 49,05 \\
\hline$x d n-26$ & $40.20-41.70$ & 4.1333 .3 & 981.65 & 1566.99 & 271.83 & 51.79 \\
\hline$x \operatorname{cin} \cdot 27$ & $41,70-43.20$ & $3.8 \quad 337.1$ & 1139.55 & 1562.18 & 147,65 & 52.87 \\
\hline$x \operatorname{tn} \cdot 05$ & $05.80-07.30$ & $4,0341,1$ & 1578.56 & 1562.37 & 41,18 & 52.74 \\
\hline$x \operatorname{tn} \cdot 06$ & $07.30 \cdot 08.80$ & $4.0345,1$ & 2947.05 & 1578,42 & 72.77 & 52,97 \\
\hline$x \operatorname{tn}-07$ & $08.80-10.30$ & $4,0 \quad 349.1$ & 1419.98 & 1576.60 & 53.24 & 52.97 \\
\hline$x \operatorname{tn}-08$ & $10.30 \cdot 11,80$ & $4,0 \quad 353,1$ & 1000,59 & 1570,08 & 33,43 & 52.75 \\
\hline$x \operatorname{tn}-09$ & $11,80-13,30$ & $4.0 \quad 357.1$ & 3434.17 & 1590,96 & 127.52 & 53.59 \\
\hline$x \operatorname{tn}-10$ & $13.30 \cdot 14.80$ & 4.0361 .1 & 2583.41 & 1601.95 & 67.07 & 53.74 \\
\hline$x \operatorname{tn}-11$ & $14,80 \cdot 16,30$ & $4.0365,2$ & 3864.62 & 1627.36 & 78.82 & $54,0\}$ \\
\hline$x \operatorname{tn}-12$ & $16.30 \cdot 20.00$ & $13.0 \quad 378.2$ & 2161,34 & 1645,71 & 45.74 & 63.73 \\
\hline$x \operatorname{tn} \cdot 13$ & $20.00-21.00$ & $2,8381,0$ & 2687.63 & 1653,37 & 37.88 & 53.61 \\
\hline$x \operatorname{tn} \cdot 14$ & $21.00-23.00$ & $18.0 \quad 399.0$ & 660.58 & 1608.68 & 145.62 & 57.76 \\
\hline$x \operatorname{tn}-15$ & $23.00 \cdot 24.20$ & $3.0 \quad 402,0$ & 2315.73 & 1613.86 & 68,90 & 57.85 \\
\hline$x \operatorname{tn}-16$ & $24.20 \cdot 25.70$ & 2.0404 .6 & 4398.09 & 1625.23 & 39.20 & 57.73 \\
\hline xse-0] & $00.00-00.80$ & $1.4 \quad 406,0$ & 2405.12 & 1627.92 & 44,11 & 57.68 \\
\hline$x$ se-02 & $00.80-02.10$ & 2.7408 .7 & 287.59 & 1617.74 & 16.36 & 57.41 \\
\hline$x$ se. 03 & $02.10 \cdot 03,60$ & $3,5 \quad 412.2$ & 487.92 & 1609.43 & 26.69 & 57.06 \\
\hline$x$ se -04 & $03.60 \cdot 04.90$ & $2,4414,6$ & 398.41 & 1602.42 & 25.76 & 56.88 \\
\hline
\end{tabular}


Tabela 6: continuação

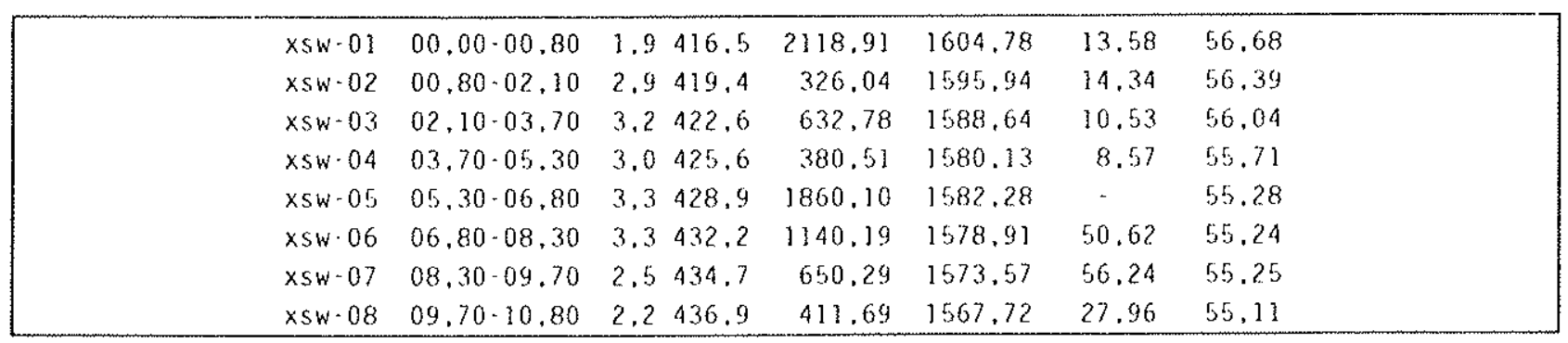

As escavações foram projetadas entre os perfis F-F' e I-I' da Figura 8, intervalo onde o pegmatito estava mal definido à superficie e as informações dos furos de sonda, à época, muito espaçadas (os furos de sonda XS-19 e XS-20 são posteriores). Elas estão representadas por um "shaft" - entre a superficie e o nivel 485 , num total de $42 \mathrm{~m}$-, galerias e travessas conforme mostra o Mapa Geológico do Xupé Sul, Figura 8, e o Mapa Geológico da Galeria do Xupé na Figura 9.

Os resultados de teores das 313 amostras (1377 determinações analíticas), correspondentes a todos os intervalos de avanço da galeria no minério pegmatítico, estão resumidos e listados na Tabela $6 \mathrm{com}$ as seguintes informaçôes: 1. nome de cada avanço; 2 . intervalo do avanço ou da amostragem $(\mathrm{m})$; 3. volume da amostra "in situ" $\left(\mathrm{m}^{3}\right)$; 4. volume acumulado $\left(\mathrm{m}^{3}\right)$; 5. teor de estanho no avanço $\left(\mathrm{g}\right.$ de $\left.\mathrm{Sn} / \mathrm{m}^{3}\right)$ ) 6. teor de estanho acumulado (g $\left.\mathrm{Sn} / \mathrm{m}^{3}\right)$; 7. teor de $\mathrm{Ta}_{2} \mathrm{O}_{5}$ do avanço $\left(\mathrm{g} \mathrm{Ta}_{2} \mathrm{O}_{5} / \mathrm{m}^{3}\right)$; 8. teor de $\mathrm{Ta}_{2} \mathrm{O}_{5}$ acumulado $\left(\mathrm{g} \mathrm{Ta}_{2} \mathrm{O}_{5} / \mathrm{m}^{3}\right)$. Ao final, os teores médios ponderados confirmaram a viabilidade técnico-econômica para lavra do Depósito Xupé, com vistas a $\mathrm{Sn}$ e $\mathrm{Ta}_{2} \mathrm{O}_{5}$.

Fontanelli (novembro/1982) forneceu os seguintes parâmetros de custo para lavra a céu aberto em material alterado:

$$
\begin{array}{ll}
\text { a - lavra } & -2.00 \text { US } \$ / t \text { de minério } \\
\mathrm{b} \text { - estéril } & -1.50 \text { US\$/t de estéril } \\
\mathrm{c} \text { - beneficiamento } & -1.00 \mathrm{US} \$ / \mathrm{t} \text { de minério } \\
\mathrm{d} \text { - administração } & -1.00 \mathrm{US} \$ / \mathrm{t} \text { de minério }
\end{array}
$$

Admitindo-se uma recuperação de $75 \%$, a $12.00 \mathrm{US} \$ / \mathrm{Kg}$ de $\mathrm{Sn}$ contido, obter-se-ia um teor mínimo de $0,5 \mathrm{Kg}$ de $\mathrm{Sn} / \mathrm{t}$ de rocha como economicamente viável.

$$
\begin{aligned}
& \text { Receita }=12.00 \mathrm{t}_{\mathrm{i}} \times 0,75=9.00 \mathrm{t}_{\mathrm{j}} \\
& \text { Custos }=2+1.5 \mathrm{R}+1.5+1.0
\end{aligned}
$$

onde $\mathrm{t}_{\mathrm{i}}=$ teor em $\mathrm{KgSn} / \mathrm{t}$ e $\mathrm{R}=$ relação estéril/minério. 
Receita $=$ Custos

$9.00 \mathrm{t}_{\mathrm{i}}=4.50+1.50 \times \mathrm{R}$

para $\mathrm{R}=0, \mathrm{t}_{\mathrm{i}}=4.50 / 9.00=0.500 \mathrm{KgSn} / \mathrm{t}$.

\subsection{Exatidão da localização dos pontos de dados}

Os trabalhos na região em estudo, cobriram uma área de aproximadamente $0,16 \mathrm{Km}^{2}$, e constam do Mapa Geológico do Xupé Sul, Figura 8, apresentados à escala 1:1000. Os pontos de interesse a pesquisa, tais como, contato litológico, catas de garimpeiros, localização dos furos de sondagem, ponto de emboque do "shaft", posição da Planta-Piloto e outros, foram controlados, à superficie, por levantamento planialtimétrico à escala 1:500. Por outro lado, os trabalhos subterrâneos envolvendo a direção das galerias e travessas, inclinação do piso, posição e intervalo de cada avanço, mapeamento geológico e outros, foram controlados por levantamento à escala 1:100. A direção dos furos de sondagem é admitida como não enviesada, por falta de medidas específicas que indicassem a possibilidade de terem eles sido desviados. Os pontos levantados nos trabalhos subterrâneos foram considerados altamente confiáveis, pela escala de detalhe da topografia.

A importância da exata localização de pontos de dados está na correta determinação dos volumes de minério - como por exemplo, a posição exata dos perfis de sondagem contíguos para cálculo da área e volume de minério entre perfis, ou mesmo a posição exata dos intervalos de avanço da galeria num cálculo de reserva -, que podem ser convertidos em peso, pela aplicação do fator tonelagem ou densidade aparente adequado. Caso os dados não estejam corretamente posicionados, os volumes determinados estarão enviesados dos volumes reais pelo erro geométrico, e podem causar grandes distorções nos resultados obtidos.

\subsection{Técnica de sondagem e recuperação média}

Os furos de sonda foram feitos com inclinação de $60^{\circ}$ e $45^{\circ}$, até o mínimo $50,84 \mathrm{~m}$ e o máximo $194,48 \mathrm{~m}$ de profundidade, conforme relação de furos e recuperação média listada na Tabela 56. A sonda rotativa a diamante utilizada é da marca Macksonda, com berço do tipo retrátil e acionamento feito por um motor diesel Perkins de 4 cilindros. A capacidade nominal de furação da Mack-700 é de 330 e 240 m, respectivamente para os diâmetros BX e NX. 
De acordo com a variabilidade no grau de alteração ou interceptação de zonas de fraqueza ao longo dos litotipos recortados, houve necessidade de revestir o furo em diâmetro NX para evitar o desmoronamento das paredes, com risco de prisão das hastes ou, ainda, para evitar a perda de água de perfuração.

O desenvolvimento do furo de sonda se fez, usualmente, pelo recorte da rocha e retirada do testemunho utilizando-se um conjunto de equipamentos, com diâmetro NX ou BX, constituido de: sapata de pastilha de vídea ou coroa diamantada cravada, acoplada, seqüencialmente, ao alargador, barrilete simples ou duplo móvel e hastes de diâmetro BX.

O avanço ou incremento do furo estava restrito ao tamanho do barrilete em uso, ou seja, de no máximo $3,05 \mathrm{~m}$, no qual vem alojar-se o testemunho à medida que for cortado.

Durante o processo de perfuração da rocha, água de superficie é seguidamente injetada até a coroa para refrigerar e evitar o desgaste prematuro da peça. No caso estudado, a lama bentonítica substituiu a água com muita eficiência, principalmente para vedar as paredes do furo e reduzir rapidamente as perdas de água ou aumentar a recuperação do testemunho em material que seria facilmente desagregável por água.

A recuperação da sondagem a diamante, de cada avanço perfurado, foi calculada em função dos intervalos amostrados e dos testemunhos recuperados e medidos fora do barrilete. A razão porcentual entre a espessura recuperada e perfurada para todos os furos em estudo revela uma recuperação média da ordem de $83 \%$. Para os intervalos amostrados ao longo de rocha pegmatítica e listados na Tabela 5 , a recuperação média é de $79 \%$.

\subsection{Técnica de amostragem nos furos de sondagem}

Foram executados furos segundo a técnica de sondagem rotativa a diamante, e as amostras obtidas na subsuperficie do corpo de minério permitiram uma testemunhagem contínua dentro destes parâmetros: nos três primeiros metros elas eram recuperadas pela técnica de embuchamento e, dai em diante, com barrilete simples ou duplo móvel.

Embuchamento é uma técnica de amostragem, executada preferencialmente em solos firmes e duros, que consiste de fazer penetrar no solo, por ação compressiva e baixa rotação da sonda rotativa, um tubo (p.ex., revestimento ou barrilete simples) com sapata denteada ou de pastilha, sem a circulação de água. O testemunho aloja-se no interior do tubo, na forma de um tampão, e, quando a tubulação é alçada à superficie, o testemunho é retirado mediante a injeção de água sob pressão.

O diâmetro inicial NX dos furos foi reduzido para BX, na passagem das zonas saprolitizadas para as menos alteradas, até o fim do furo. 
Alçados à superficie, os testemunhos, de tamanho máximo igual ao barrilete em uso e correspondentes a cada avanço amostrado, foram lavados, e o excesso de lama removido. Após uma descrição físico/litológica inicial, foram individualizados alguns intervalos mais interessantes e de tamanhos variáveis de acordo com a litologia.

Os testemunhos eram inicialmente cortados ao meio e observados em suas novas apresentações, para complementar a primeira descrição macroscópica, e, em seguida, uma das metades era novamente cortada ao meio. Esse $1 / 4$ da amostra inicial era destinado às análises químicas e os restantes $3 / 4$, armazenados nas caixas de testemunhos.

Para o corte utilizou-se um partidor manual de testemunhos, que, somente nas rochas homogêneas isótropas, produz um corte regular; portanto, na partição de testemunhos, nem sempre se obtêm amostras iguais em volume. Ademais, os furos iniciais (XS-01, XS-02, XS-03, XS-04, XS-05 e XS-06) foram amostrados com lascas ou fragmentos, coletados manualmente dos testemunhos ao longo dos intervalos de maior interesse.

Essa amostragem nos furos de sondagem, pode-se dizer que não foi satisfatória, pois houve variação dos volumes amostrados, em decorrência dos diferentes processos empregados na coleta dos testemunhos. Por conseguinte, esse erro de amostragem, segundo Miesch (1967), representa a diferença composicional entre a amostra de rocha e a parte do corpo dela com que se espera representá-la. Essa diferença de volumes amostrados implica, por outro lado, a representatividade da amostragem (relação volume $\mathrm{x}$ variância = constante) e o erro de estimativa decorrente da extensão do teor da amostra, de pequeno volume, para um bloco do minério, de volume muito maior (milhares de vezes).

Observe-se, a propósito que, se todas as amostras tivessem o mesmo volume e todos os blocos de minério fossem de volume idêntico, a relação de representatividade (volume da amostra/volume do minério) da amostragem seria constante, entretanto não foi isso que ocorreu no caso em estudo.

\subsection{Técnicas de amostragen nas escavações subterrâneas}

As escavações subterrâneas transversais e ao longo do corpo de minério estão representadas, neste estudo, pelas galerias longitudinais - $\mathrm{XDN}, \mathrm{XDS}_{1}$ e $\mathrm{XDS}_{2}$ - e travessas XDT, XTN, XDS, XSE e XSW, conforme esquema ilustrado pela Figura 20. 


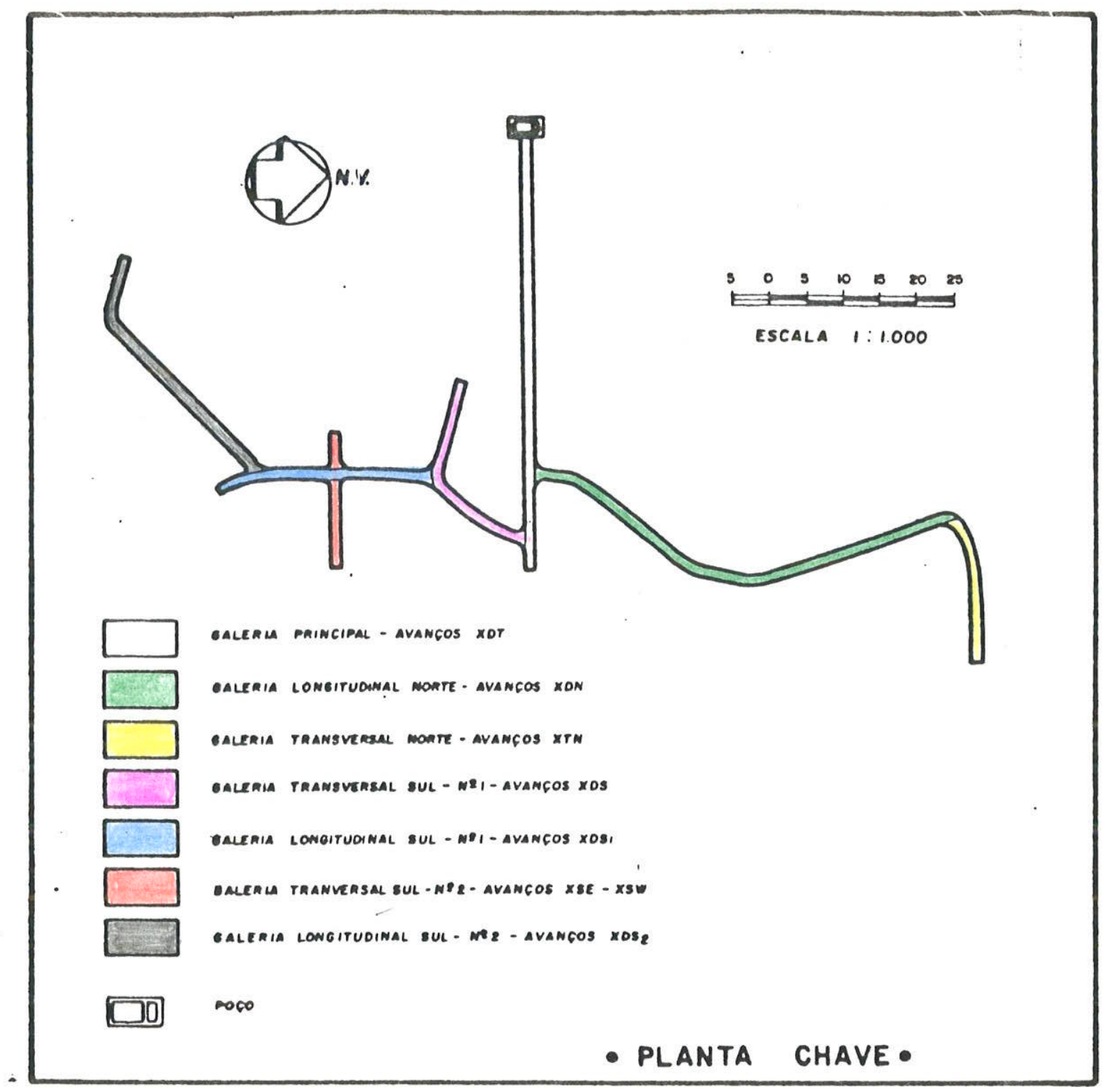

Figura 20. Planta esquemática das escavações subterrâneas na pesquisa do Pegmatito Xupé (equipe Brumadinho).

Elas foram executadas com objetivo de investigar a continuidade das mineralizações de estanho primário garimpadas em superficie; e obter amostras volumétricas para serem determinados os parâmetros físicos quantitativos e as características tecnológicas do minério.

$\mathrm{Na}$ seqüência dos trabalhos exploratórios precederam a abertura dessas escavações outras técnicas de amostragem menos onerosas como poços, trincheiras e sondagens.

Dada a forma aplainada da configuração topográfica, houve necessidade da escavação de poço ("shaft") em terreno menos alterado, para poder suportar a infra-estrutura (gaiola, redes elétrica, hidráulica e de ar) com segurança e permitir acesso às galerias projetadas. Ele foi 
escavado com dimensões de 3,00 por $1,90 \mathrm{~m}$ e $42 \mathrm{~m}$ vertical, até o nivel $485 \mathrm{~m}$. A partir deste foi iniciada a abertura de uma galeria transversal de $60 \mathrm{~m}$ e desta saía uma galeria longitudinal e 3 outras transversais. As galerias e travessas somaram $317 \mathrm{~m}$ lineares de abertura sendo que 160,60 $\mathrm{m}$ foram escavadas ao longo do corpo pegmatítico. As suas dimensões foram projetadas para aberturas de $1,30 \times 1,30 \mathrm{~m}$, com avanços médios de $1,50 \mathrm{~m}$ e inclinação ascendente da ordem de $0,5 \%$, para o escoamento de água.

O método de desmonte utilizado para o desenvolvimento das aberturas subterrâneas foi por explosivo, transporte em vagonetes ou carrinhos de mão.

Durante a abertura da galeria, dentro do corpo pegmatítico, todo material desmontado a cada avanço-e, em algumas situações, a cada dois avanços-constituia uma amostra do tipo volumétrica. Essas amostras possuiam os seguintes registros: nominação sequencial (p.ex., XDT$1,2 \ldots X D T-12$ ), intervalo de amostragem medido a partir dos pontos de amarração internos (p.ex, o intervalo da amostragem $X D S-1=0,00$ até 1,45 ) e volume (medido em função do intervalo da amostragem multiplicado pela área média da abertura). Todo o material desmontado foi retirado e transportado para a planta-piloto, ou seja, sem nenhuma preparação.

\subsection{Preparação e análise das amostras dos furos de sondagem}

Porque as amostras dos furos de sonda, representadas por frações de testemunhos de sondagem, são geralmente volumosas demais para a análise química, torna-se necessário preparálas. Koch \& Link (1971) apontam dois objetivos principais nessa preparação:

a) reduzir a quantidade das amostras geológicas;

b) homogeneizá-las.

Para preparar as amostras coletadas, cumpriram-se os seguintes procedimentos:

- britagem manual para $<4 \mathrm{~mm}$;

- homogeneização;

- quarteamento.

Pela britagem manual o material foi reduzido a fragmentos em torno de $4 \mathrm{~mm}$, o que facilitou a mistura e a homogeneização para a retirada posterior da quantidade adequada à análise.

$\mathrm{O}$ "quarteamento" constituiu a etapa final de preparação da amostra. Esse quarteamento foi realizado no laboratório de campo da Empresa num "quarteador", tipo Jones, até a amostra ficar reduzida a aproximadamente $200 \mathrm{~g}$ de material, ou de tamanho suficiente para que pudesse conter duas porções (uma para análise e outra para arquivo). Essa amostra era identificada por registro alfa-numérico seqüencial e encaminhada para análise química nos laboratórios da Geosol 
ou Metago que a submetiam à espectrografia óptica e/ou fluorescência de raios-X, como listado na Tabela 5. O restante, a contra-amostra, era arquivada na casa de amostras.

\subsection{Processamento em planta-piloto das amostras volumétricas e resultados analíticos.}

As amostras volumétricas extraidas das galerias do Xupé foram processadas na PlantaPiloto, conforme Fluxograma da Planta-Piloto na Figura 21.

Os carrinhos de mão ou vagonetes, provenientes das galerias, basculavam o material desmontado sobre um pátio cimentado, de superficie côncava, e um jato d'água de alta pressão carreava-o para uma peneira vibratória de malha $1,6 \mathrm{~mm}$.

O oversize deste peneiramento era então conduzido a um circuito de britagem/moagem. Blocos não desagregados e com diâmetro superior à boca do britador eram amarroados manualmente. $O$ produto do moinho era desaguado em uma caixa de concentração e deságue ("surge bin") que, por bombeamento, alimentava a seqüência de dois jigues primários via undersize da peneira. $O$ rejeito final desses jigues era recuperado em duas caixas de cimento seguidas, das quais se obteve o rejeito primário (material decantado) e o "overflow" (material perdido em suspensão).

$\mathrm{O}$ concentrado da jigagem primária alimentava diretamente o jigue secundário. $\mathrm{O}$ rejeito, denominado secundário, retornava para a caixa de concentração ("surge bin) e o undersize das células 5 e 6 constituiam o pré-concentrado final.

Os produtos assim obtidos - pré-concentrado, rejeito e "overflow" - foram secados, pesados e homogeneizados, e deles foram quarteadas porções para análises químicas.

As concentrações obtidas de cada uma dessas amostras foram compostas, calculando-se ao final a massa de $\mathrm{Sn}$ e $\mathrm{Ta}_{2} \mathrm{O}_{5}$ por avanço. Dividindo-se a massa de metal e pentóxido pelo volume correspondente do avanço da galeria, pôde-se calcular o teor de $\mathrm{Sn}$ e $\mathrm{Ta}_{2} \mathrm{O}_{5} \mathrm{em} \mathrm{g} / \mathrm{m}^{3}$, como apresentado na Tabela 6, colunas 5 e 7. Para estudo comparativo de teores, à mesma unidade ppm, os valores da coluna $5\left(\mathrm{Sn} / \mathrm{m}^{3}\right)$ são divididos por 2,14 (fator tonelagem). 


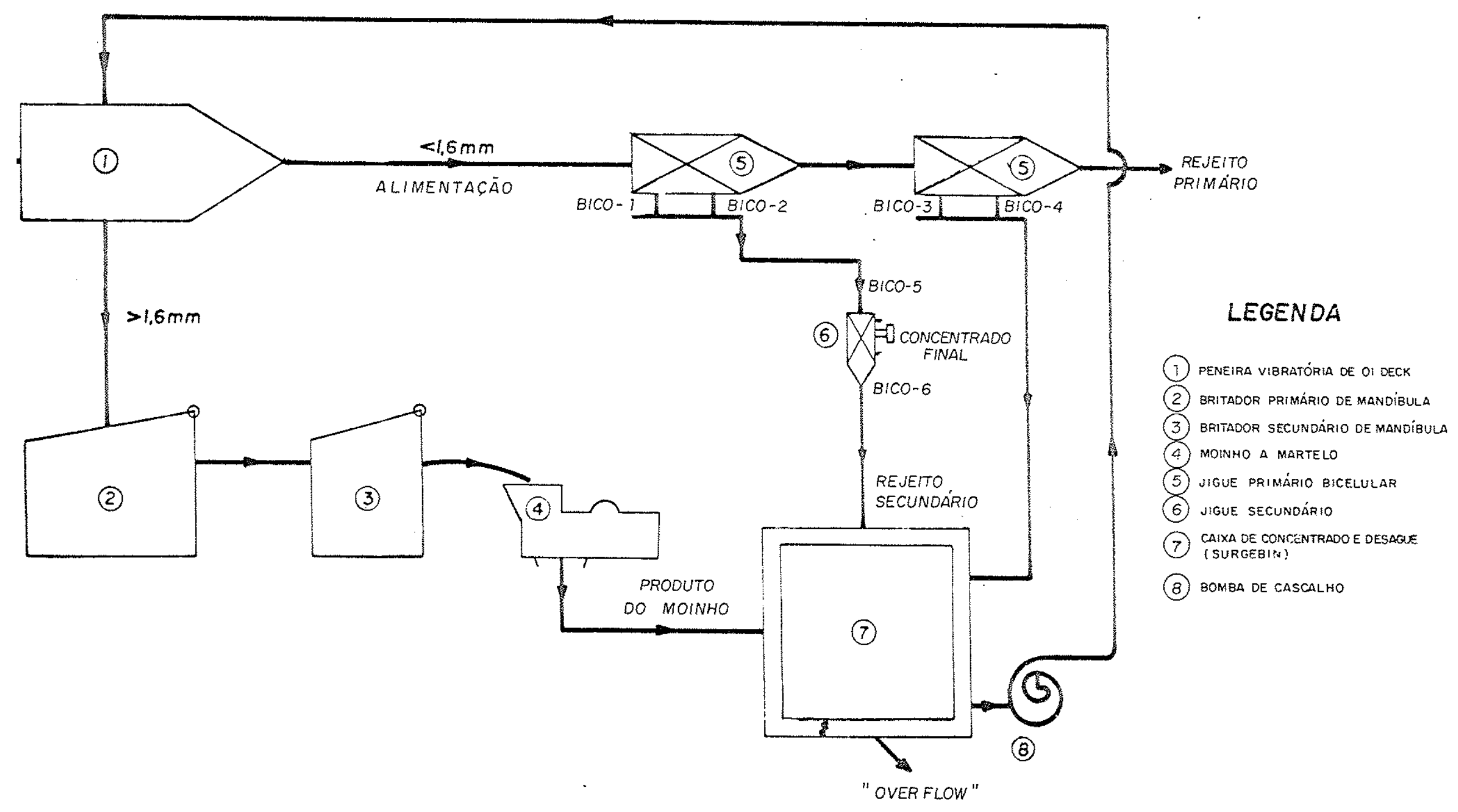

FLUXOGRAMA DA PLANTA - PILOTO XUPÉ 


\subsection{Determinação da densidade aparente ou fator tonelagem}

Para calcular o fator tonelagem uilizou-se o método da pesagem do minério escavado de um volume conhecido conforme explicado por Mckinstry, 1948. No corpo pegmatítico as quinze amostras estudadas para essa determinação apresentaram os seguintes resultados:

$\mathrm{a}-\mathrm{d}_{\mathrm{s}}=1,6 \mathrm{t} / \mathrm{m}^{3}$ - densidade de superficie, calculada a partir das medidas efetuadas com 10 poços escavados em afloramentos de superficie;

$\mathrm{b}-\mathrm{d}_{\mathrm{g}}=2,14 \mathrm{t} / \mathrm{m}^{3}$ - densidade no nivel 485 (nivel da galeria) - calculada a partir das medidas efetuadas em 4 poços escavados no interior da galeria;

$c-d_{r}=2,70 \mathrm{t} / \mathrm{m}^{3}$ - densidade em rocha sã, calculada a partir das medidas efetuadas em testemunhos de sonda rotativa (nivel 465).

Com esses valores construiu-se um gráfico de variação da densidade do pegmatito, em função da profundidade, conforme demonstra a Figura 22. Interpolando-se os valores conhecidos por meio de uma curva, pôde-se inferir uma densidade média por nivel de profundidade como segue abaixo:

\begin{tabular}{|cc|}
\hline NIVEL & DENSIDADE MEDIA $\left(\mathrm{t} / \mathrm{m}^{3}\right)$ \\
535 & 1,60 \\
525 & 1,70 \\
515 & 1,70 \\
505 & 1,70 \\
495 & 1,90 \\
485 & 2,14 \\
475 & 2,70 \\
465 & 2,70 \\
\hline
\end{tabular}

Assim, as densidades médias avaliadas mostram claramente que o corpo pegmatítico se apresenta submisso a uma ação intempérica variável entre a superficie (material intemperizado) e o nível 465 (material fresco). Apesar disso e conhecidas as implicações que esses valores e tipos de materiais têm sobre a cubagem, explotação e beneficiamento, a presente Dissertação fez uso da densidade média da galeria (nivel 485), ou seja, $d=2,14 \mathrm{t} / \mathrm{m}^{3}$. 


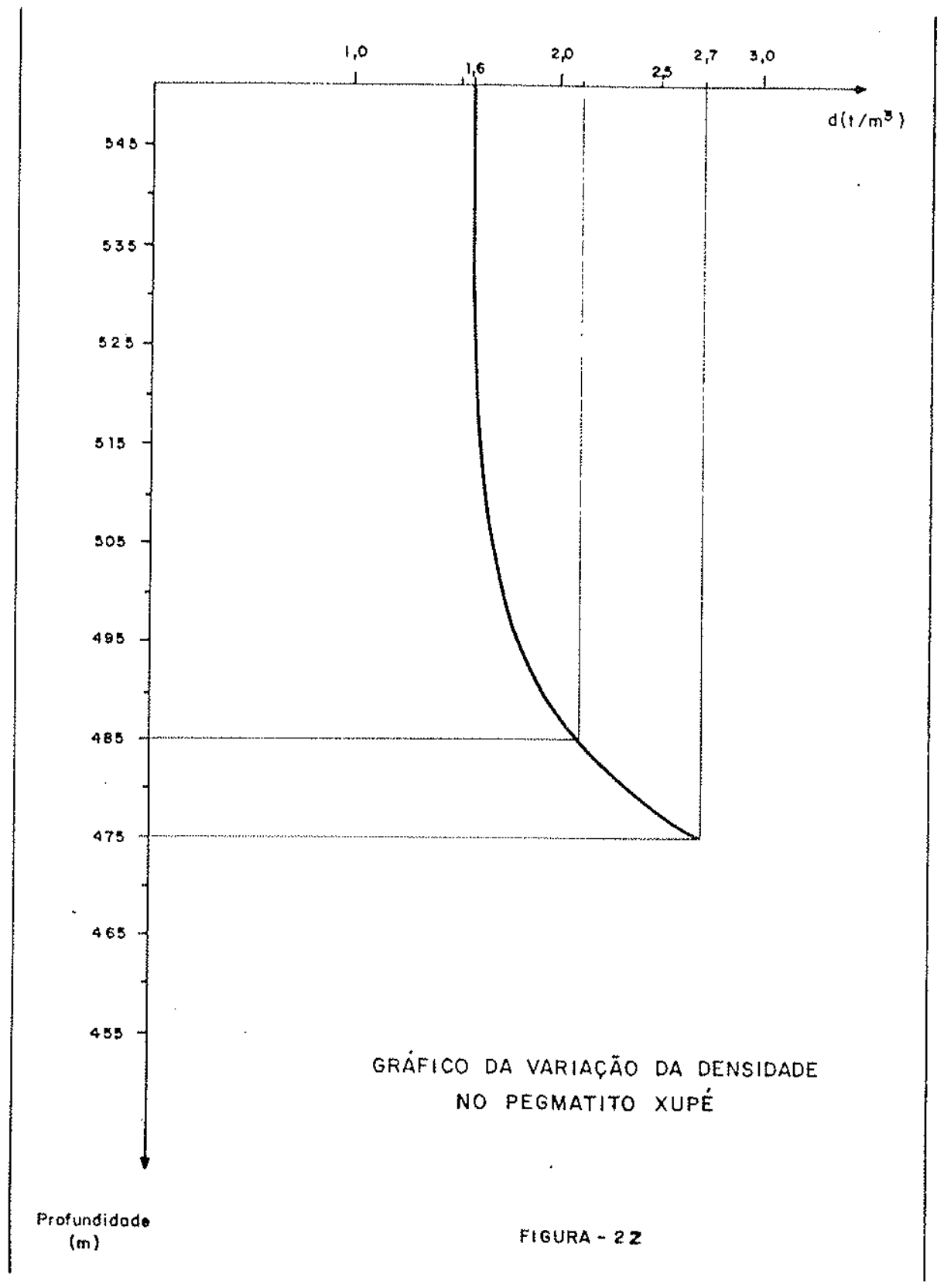

Figura 22: Gráfico de variacão da densidade no Fegmatito Xupé (Barcellos, 1985). 


\subsection{Recuperação da usina de beneficiamento}

Os fatores de recuperação da Usina de Beneficiamento se devem ao estudo de caracterização tecnológica desenvolvido pela Paulo Abib Eng.S.A. no material processado na Planta-Piloto Xupé.

Por esses estudos, pôde-se salientar que:

- $72 \%$ da cassiterita é grossa e apenas $1 \%$ está abaixo de $0,21 \mathrm{~mm}$;

- as cassiteritas mostram um grau de liberação de até 95\% nas frações abaixo de 0,2] malhas e da ordem de $90 \%$ entre 0,42 e $0,21 \mathrm{~mm}$;

- a assembléia mineralógica associada à cassiterita é formada de quartzo, feldspato, muscovita e montmorilonita (que somam $98 \%$ do minério), magnetita, turmalina, apatita e sulfetos (pirita e calcopirita);

Após o processamento de 101 amostras volumétricas da galeria, ou o total correspondente a $436,90 \mathrm{~m}^{3}$ de minério na Planta.Piloto do Xupé, foram obtidos teores médios ponderados de $1567,72 \mathrm{gSn} / \mathrm{m}^{3}$ e $55,11 \mathrm{~g}$ de $\mathrm{Ta}_{2} \mathrm{O}_{5}$, conforme resultados demonstrados na Tabela 6. 


\section{CAlítrulo 7}

\section{ESTATÍSTICA DOS DADOS DE AMOSTRAGEM}

Para o melhor entendimento do comportamento das variáveis de interesse dentro do Depósito Xupé, ou seja, dos teores de estanho e dos intervalos amostrados nas galerias e testemumhos, procedeu-se a uma análise estatística dos dados disponiveis e/ou criados a partir de resultados analíticos de testemunhos de sondagem e avanços das galerias.

Esses resultados analíticos, quanto aos testemunhos de sondagem, representam $95,18 \mathrm{~m}$ ou 115 intervalos individualizados de amostragem em corpos pegmatíticos expostos nos testemunhos dos furos: XS-1; XS-2; XS-3; XS-4; XS-5; XS-6; XS-7; XS-8; XS-10; XS-11; XS12 e XS-18. O tamanho dos intervalos de amostragem variam entre 0,10 até $4,0 \mathrm{~m}$ e a amostra correspondente possui volume igual a $1 / 4$ do testemunho ou o volume médio aproximado de 0,0007 e $0,0012 \mathrm{~m}^{3}$, respectivamente para os intervalos com diâmetro BX e NX.

As amostras de galerias correspondem a todo material do corpo de minério desmontado durante os avanços das galerias. Elas ostentam volume médio de $4 \mathrm{~m}^{3}$ e foram coletadas sistematicamente a cada avanço - ao longo de $160,60 \mathrm{~m}$ de corpo de minério - e beneficiada sem preparação.

Para comparar teores de testemunhos e avanços, à mesma unidade "ppm", os teores de estanho no avanço - Tabela 6 , coluna 5 - foram divididos pelo fator tonelagem igual a $2,14 \mathrm{t} / \mathrm{m}^{3}$.

A análise estatística de dados tem como objetivo a caracterização e descrição precisa das populações amostradas, por meio do estudo das distribuições de freqüências e de suas características numéricas descritivas (média, desvio padrão, assimetria e curtose) para uma estimativa inicial do teor médio e variabilidade do depósito. Assim as populações amostradas nos furos de sondagem e nas escavações subterrâneas poderão ser comparadas e consequientemente interpretadas. 


\subsection{Distribuições de freqüências}

No contexto geral da Análise Estatística Clássica, os primeiros estudos começam com a distribuiçầo de freqüências, as quais se baseiam na freqüência de ocorrência dos valores nos pontos de amostragem. Para isso, assume-se a hipótese de independência entre amostras e probabilidade de todas elas terem a mesma ocorrência. Dessa forma é possível fazer o estudo das distribuições de freqüências das populações amostradas. Para estudo dos teores de estanho nos furos de sondagem como nas galerias, esses dados foram tabulados em listagens. Segundo Koch \& Link (1971), para se compreender um grande número de informações de listagens, deve-se organizar, classificar, agrupar e calcular a média dessas observações. Assim, a organização dos dados em estudo resultaram numa distribuição de freqüencia. Os dados foram agrupados em classes predeterminadas; a freqüência da ocorrência de pontos em cada intervalo, dividida pelo número total de pontos, originou a freqüencia porcentual simples; e esta, quando acumulada, originou a freqüência porcentual acumulada.

A distribuição de frequência proporciona uma primeira aproximação sobre a forma de distribuição dos dados, bem como permite inferir o valor de ocorrência mais provável (moda) e também dá uma idéia da dispersão associada.

Para os dados de estanho dos furos, as distribuições encontram-se nas tabelas 7 e 8 .

Tabela 7: Distribuição de freqüências dos teores de estanho nos testemunhos de sondagem.

\begin{tabular}{|c|c|c|c|c|}
\hline \multicolumn{2}{|c|}{$\begin{array}{l}\text { CLASSES } \\
(\mathrm{ppm})\end{array}$} & \multicolumn{3}{|c|}{ FREOUEENCIAS } \\
\hline 0,00 & 350.00 & 89 & 77,39 & 77,39 \\
\hline 350,00 & a 700,00 & 16 & 13,91 & 91,30 \\
\hline 700,00 & a 1050,00 & 3 & 2.61 & 93,91 \\
\hline 1050,00 & a 1400,00 & 2 & 1,74 & 95,65 \\
\hline $1400,00 a$ & a 1750,00 & 1 & 0,87 & 96.52 \\
\hline 1750,00 & 2100,00 & 1 & 0,87 & 97.39 \\
\hline 2100,00 & 2450,00 & 0 & 0.00 & 97,39 \\
\hline 2450,00 & d 2800,00 & 0 & 0,00 & 97,39 \\
\hline 2800,00 & 3150,00 & 0 & 0.00 & 97,39 \\
\hline 3150,00 & 3500,00 & 1 & 0.87 & 98,26 \\
\hline 3500,00 & 3850,00 & 0 & 0,00 & 98.26 \\
\hline 3850,00 a & 4200,00 & 1 & 0,87 & 99.13 \\
\hline $4200,00 a$ & a 4550,00 & 0 & 0,00 & 99,13 \\
\hline $4550,00 a$ & a 4900,00 & 0 & 0,00 & 99,13 \\
\hline 4900,00 a & a 5250,00 & 1 & 0.87 & 100,00 \\
\hline TOTA & AIS & 115 & 100,00 & \\
\hline
\end{tabular}


Tabela 8: Distribuição de freqürencias dos iogaritmos dos teores de estanho nos testemmuhos de sondagem.

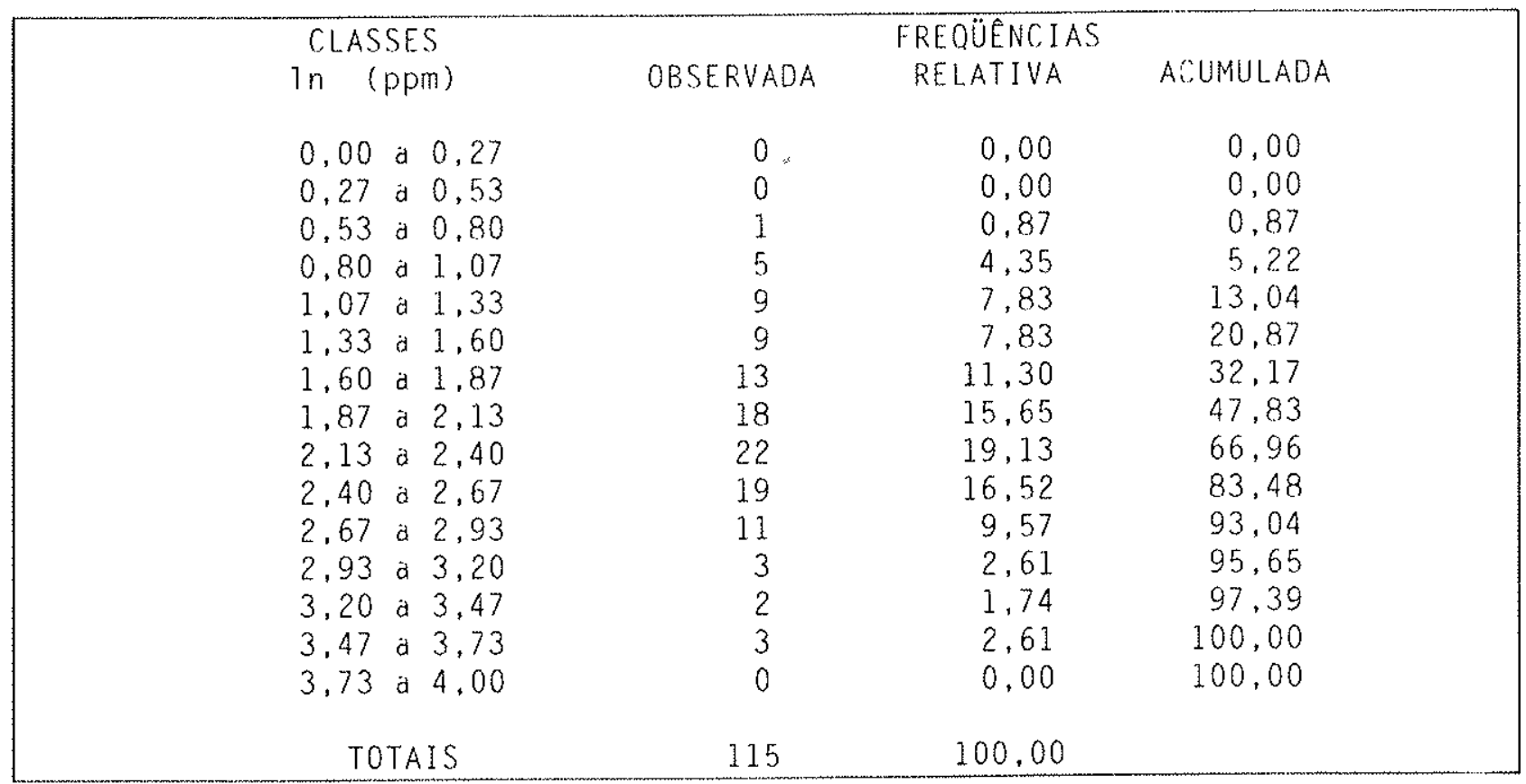

Observe-se que as distribuições de freqüência são apresentadas tanto em valores originais (Sn - ppm), como também em logaritmo desses valores $(\log (\mathrm{ppm}))$. A partir de distribuição de freqüência dos valores originais, pode-se observar que o valor médio mais provável de ocorrência estará entre 0 (zero) e 350 ppm de estanho, pois é a moda dessa distribuição de freqüência.

Organizando-se os dados de estanho das análises dos avanços das galerias, foram calculadas as distribuições de freqüências apresentadas nas Tabelas 9 e 10, respectivamente dos dados originais e dados transformados pelos logaritmos. 
Tabela 9: Distribuição de freqüencias dos teores de estamho nos avanços das galerias.

\begin{tabular}{|c|c|c|c|c|c|}
\hline & \multirow{2}{*}{\multicolumn{2}{|c|}{$\begin{array}{c}\text { CLASSES } \\
(\mathrm{ppm})\end{array}$}} & \multicolumn{3}{|c|}{ FREQÜENCIAS } \\
\hline & & & OBSERVADA & RELATIVA & ACUMULADA \\
\hline & 75,00 & 255,00 & 14 & 13,86 & 13,86 \\
\hline . & 255,00 & 435,00 & 18 & 17,82 & 31,68 \\
\hline & 435,00 & a $\quad 615,00$ & 15 & 14.85 & 46,53 \\
\hline & 615.00 & 795,00 & 12 & 11,88 & 58,42 \\
\hline & 795,00 & 1155,00 & 10 & 9.90 & 68.32 \\
\hline & 1155,00 & 1335,00 & 10 & 9.90 & 78,22 \\
\hline & 1335.00 & 1515,00 & 7 & 6.93 & 85,15 \\
\hline & 1515,00 & 1695,00 & 5 & 4,95 & 90,10 \\
\hline & 1695,00 & 1875,00 & 4 & 3,96 & 94,06 \\
\hline & 1875,00 & 2055,00 & 1 & 0,99 & 95.05 \\
\hline & 2055,00 & 2235,00 & 3 & 2,97 & 98,02 \\
\hline & 2235,00 & 2415.00 & 1 & 0.99 & 99,01 \\
\hline & 2415,00 & 2595,00 & 0 & 0,00 & 99.01 \\
\hline & 2595,00 & 2775,00 & 1 & 0.99 & 100,00 \\
\hline & TOT & AIS & 101 & 100,00 & \\
\hline
\end{tabular}

Tabela 10: Distribuição de freqüências dos logaritmos dos teores de estanho nos avanços das galerias.

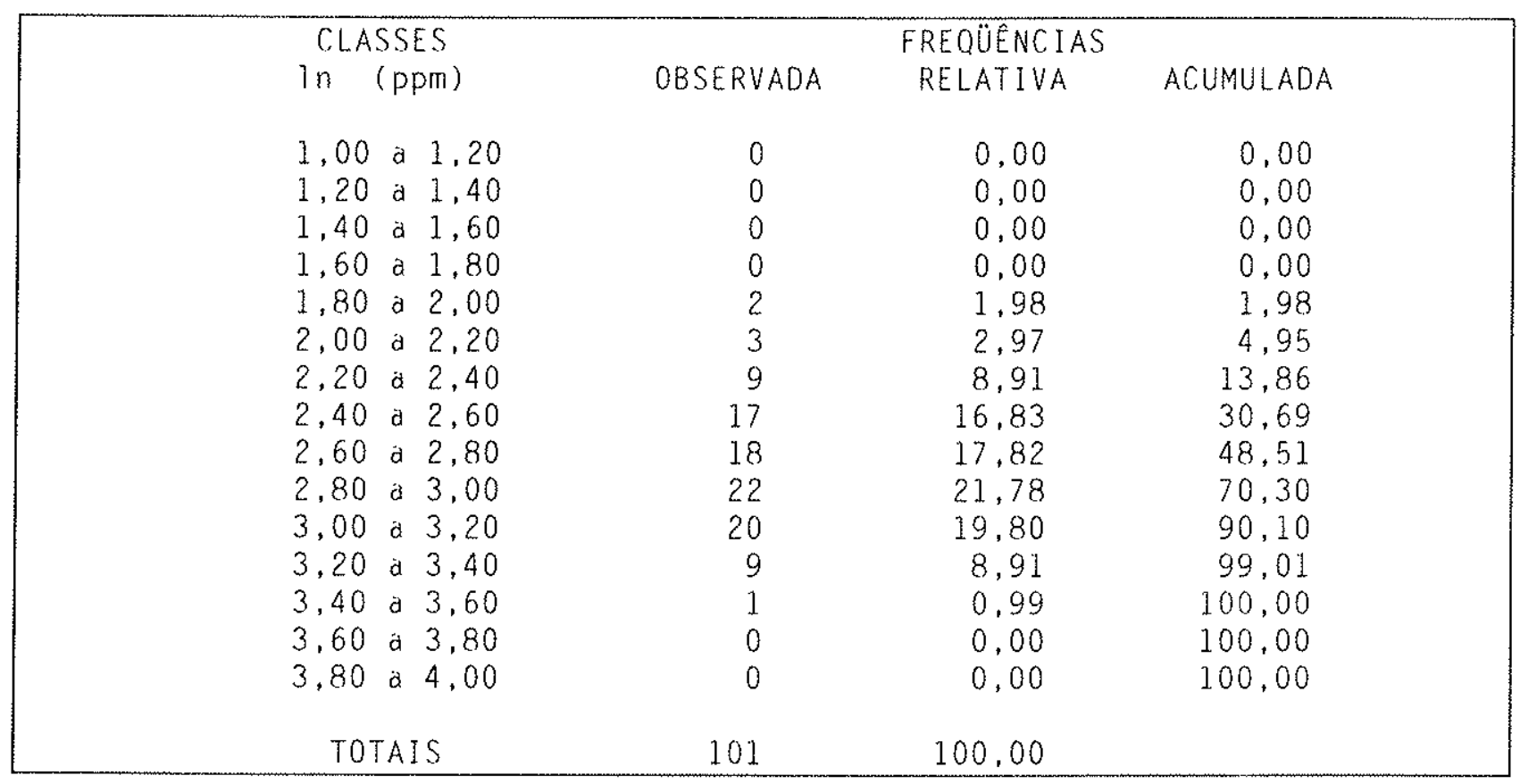


Para esta distribuição (Tabela 9) a moda está entre 255 e 435 ppm, porém não necessariamente indica o valor mais provável de ocorrência devido à dispersão dos valores em muitas classes.

\subsubsection{Representações gráficas de distribuição de freqüência}

A distribuição dos teores de estanho do Depósito Xupé está representada na forma gráfica por meio de histogramas e curvas acumulativas.

Para os dados de estanho dos furos construírammse os histogramas e curvas acumulativas apresentados nas Figuras 23 e 24, para os dados originais, e nas Figuras 25 e 26, para os dados transformados.

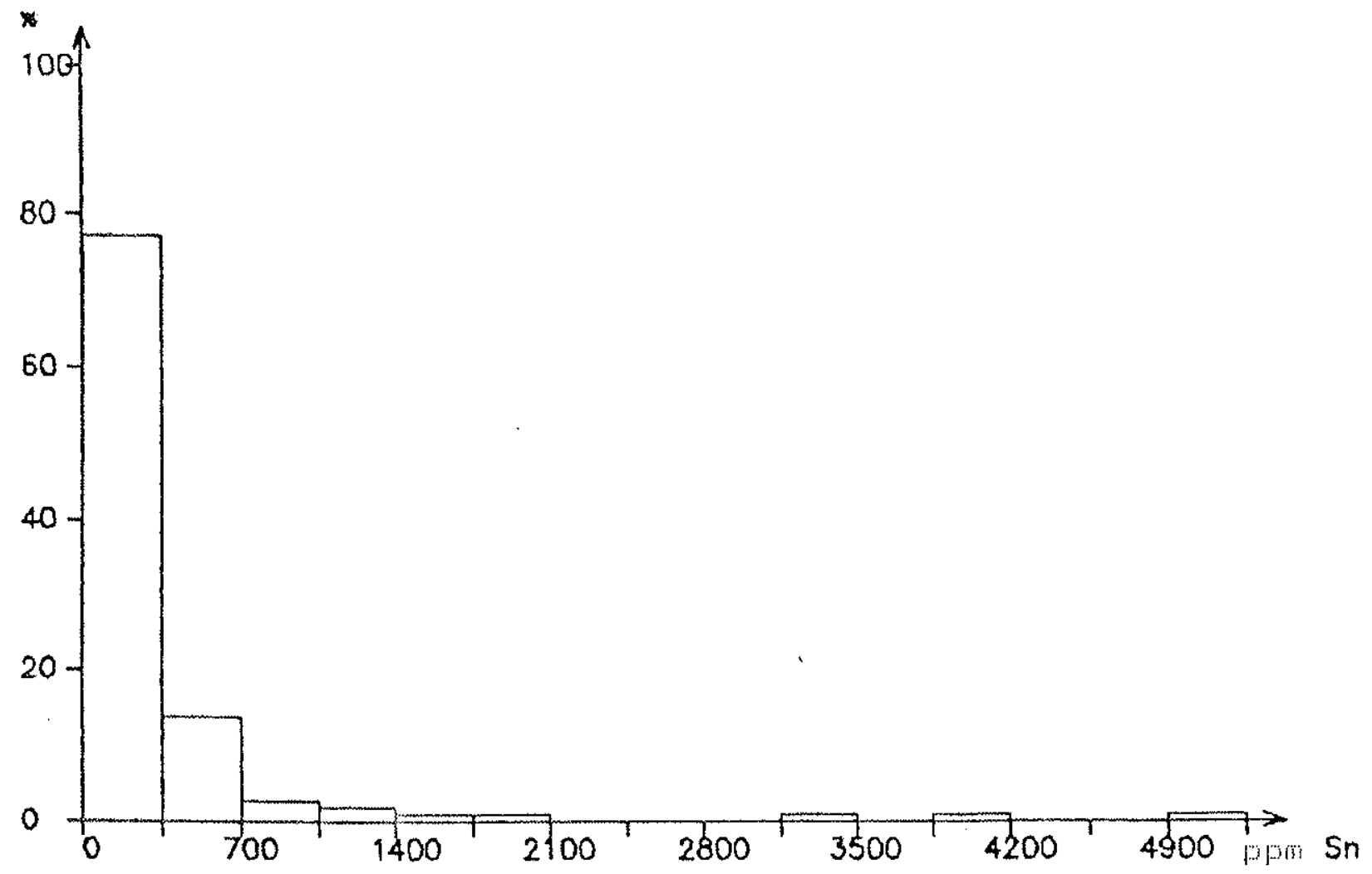

Figura 23: Histograma das distribuições de freqüências de teores de estanho nos testemunhos das sondagens. 
(6)

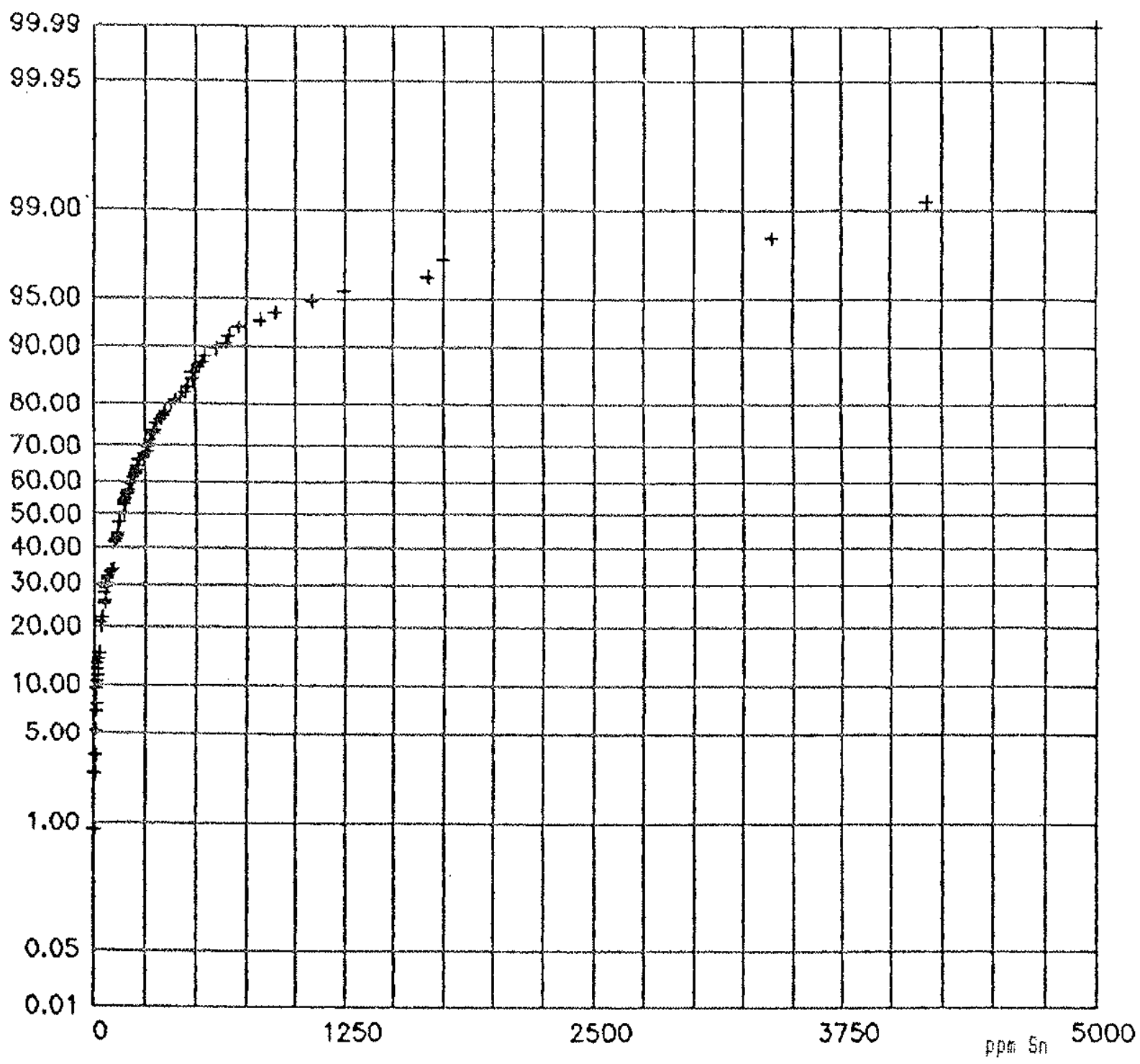

Figura 24: Curva acumulativa em escala de probabilidade aritmética da distribuição de teores de estanho nos testemmhos das sondagens.

Na Figura 23, pode-se observar que quase $80 \%$ dos valores amostrados se encontram numa única classe ( 0 e $350 \mathrm{ppm}$ ). Verifica-se também que esta distribuição é altamente assimétrica, com assimetria positiva, demonstrando que esta distribuição não é normal, podendo ser lognormal.

Confirmando o comportamento observado no histograma da Figura 23, a curva acumulativa, Figura 24, desenha uma curva, mostrando que a distribuição não segue uma distribuição normal. 
A Figara 25, ou seja, o histograma dos logaritmos dos valores de estanho amostiàdos nos furos já apresenta uma certa simetria, introduzida pela transformação logarítmica, mostrando que a mesma tende a lognormal.

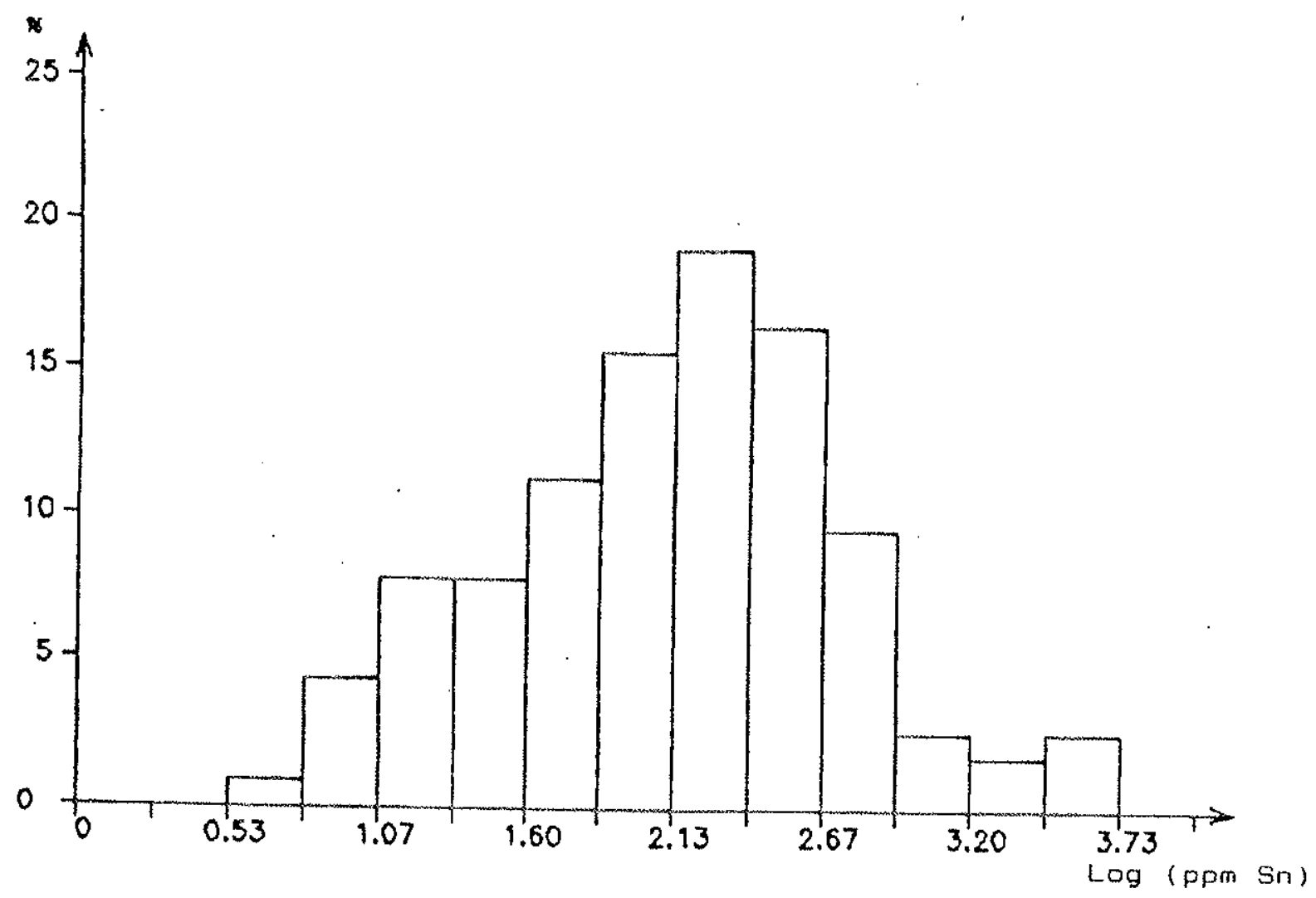

Figura 25: Histograma logaritmico das distribuições de freqüências e estanho nos testemumhos de sondagem.

A curva acumulativa em papel de log probabilidade aritmética da Figura 26 já se apresenta aproximadamente como uma reta, não estando perfeitamente sobre a reta pela pequena assimetria restante da transformação dos logaritmos dos valores. Contudo, pode-se afirmar que a distribuição dos teores de estanho amostrados nos furos tende a uma distribuição lognormal. 


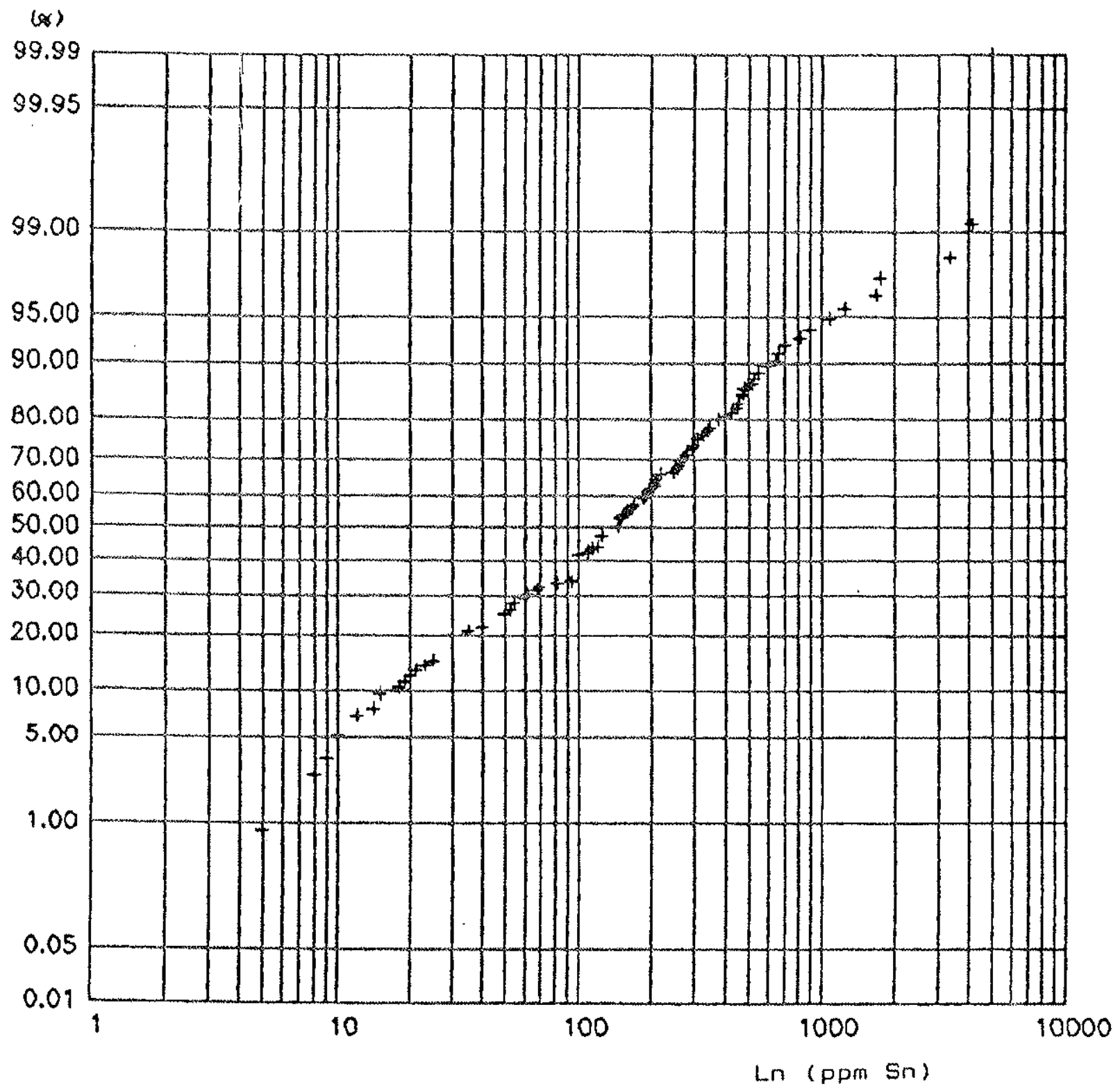

Figura 26: Curva acumulativa em papel de log probabilidade aritmética para distribuição de estanho nos testemmhos das sondagens.

Para os dados de estanho amostrados ao longo das galerias, obtiveram-se os histogramas e curvas acumulativas apresentados nas Figuras 27 e 28 , para os valores originais. 


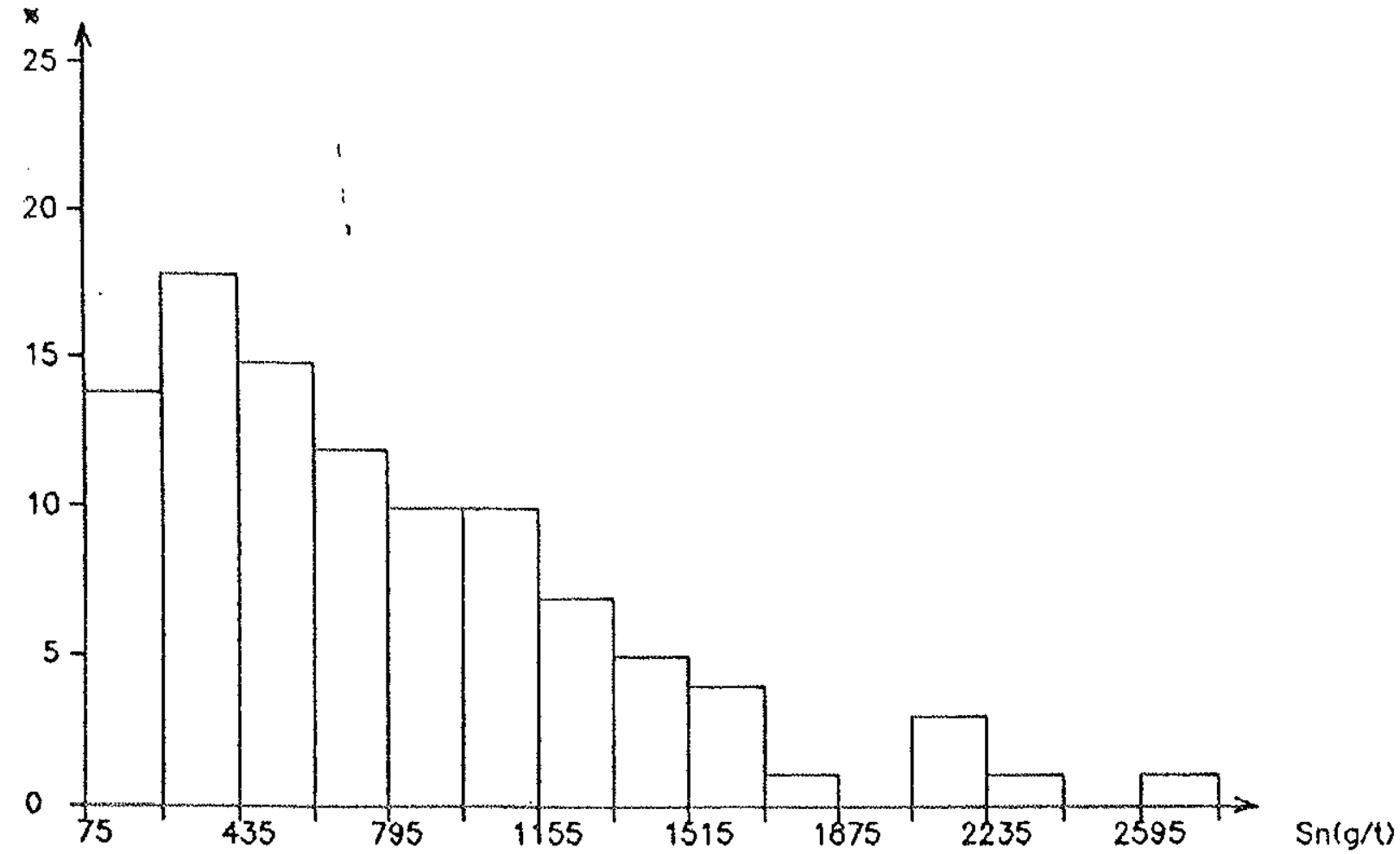

Figura 27: Histograma das distribuiçóes de freqüências de teores de estanho mos avamģos das galerias. 
(ख)

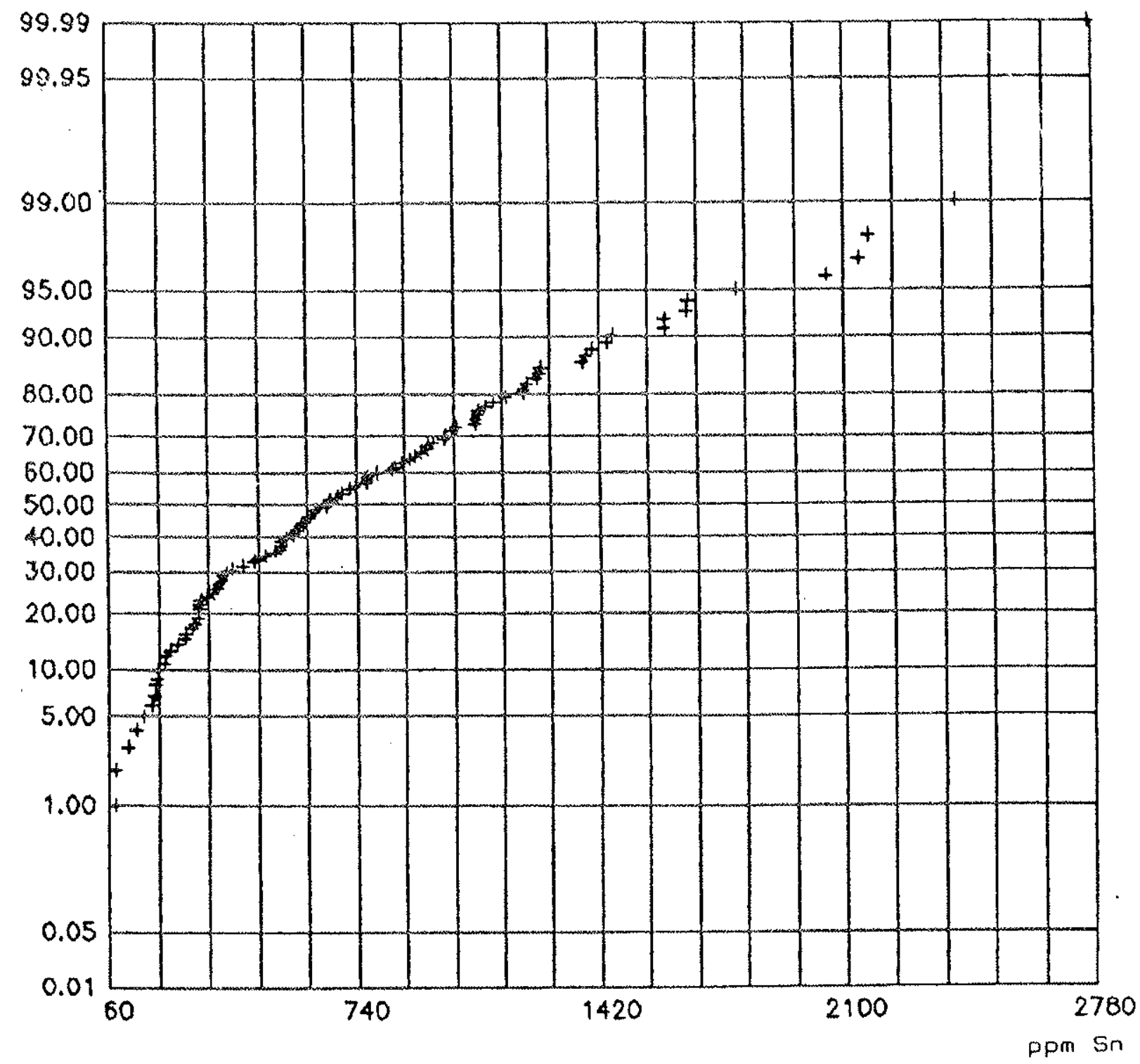

Figura 28: Curva acumulativa em escala de probabilidade aritmética da distribuição de teores de estanho nos crvanços das galerias.

A distribuição de freqüência simples dos dados de estanho nos avanços, representada por meio do histograma da Figura 27, continua mostrando uma distribuição assimétrica, com assimetria positiva. Porém, ao contrário do histograma da Figura 23, em que aproximadamente $80 \%$ dos dados estavam numa única classe $(0-350 \mathrm{ppm})$, nesse caso os dados encontram-se melhor distribuídos, indicando que a dispersão é menor que a verificada nos furos.

A Figura 28 mostra uma distribuição acumulada não normal, pois ela representa-se sob forma de curva. 
Fazendo-se a transformação logárítmica dos dados de estanho nos avanços, obtém-se pelo histograma da Figura 29 uma distribuição mais simétrica, porém não perfeitamente simétrica, o que indica que a distribuição também não pode ser lognormal, fato este confirmado pela curva acumulativa da Figura 30 em papel de log probabilidade aritmética.

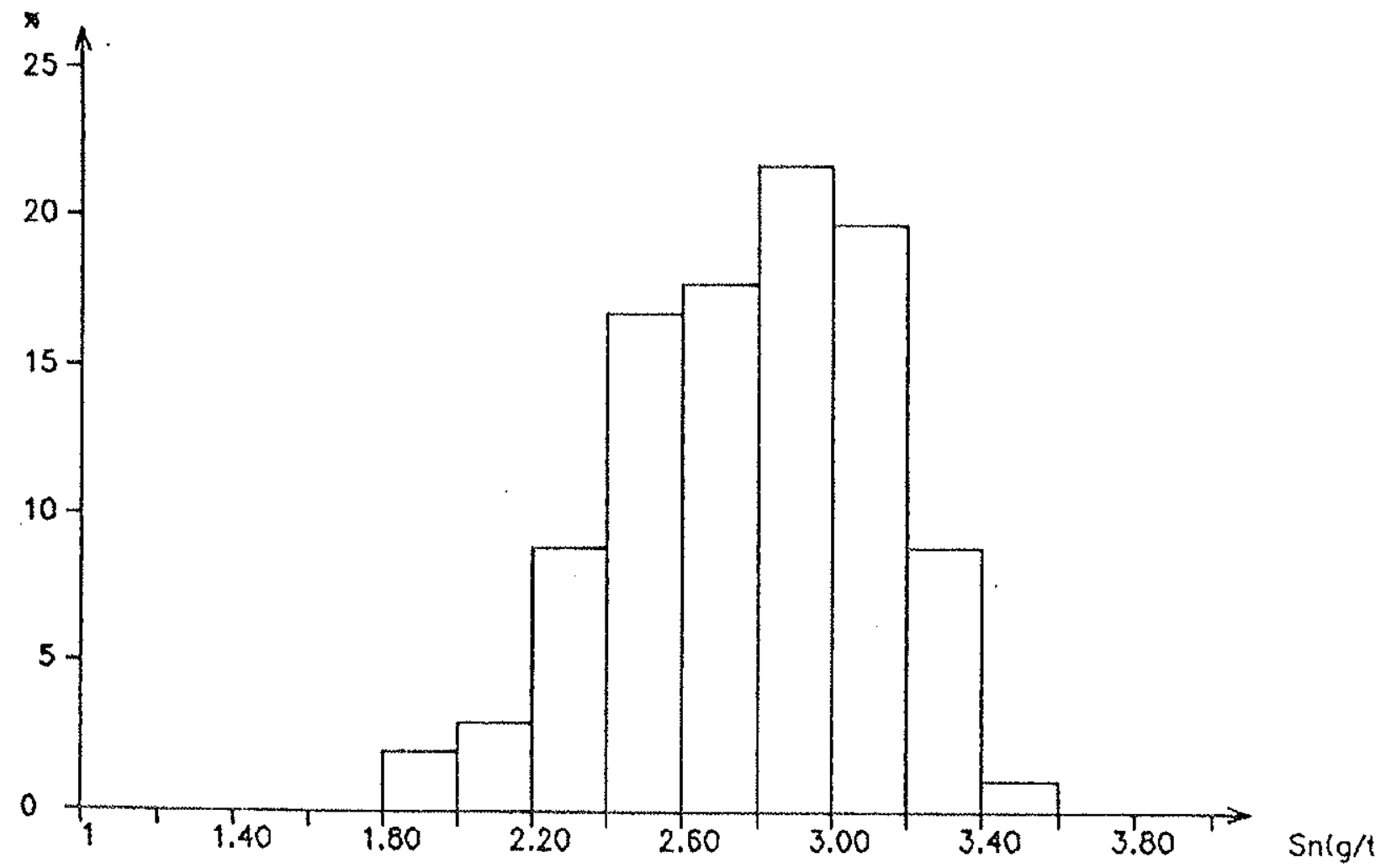

Figura 29: Histograma das distribuições de freqüuências logaritmica dos teores de estanho em avanços das galerias 


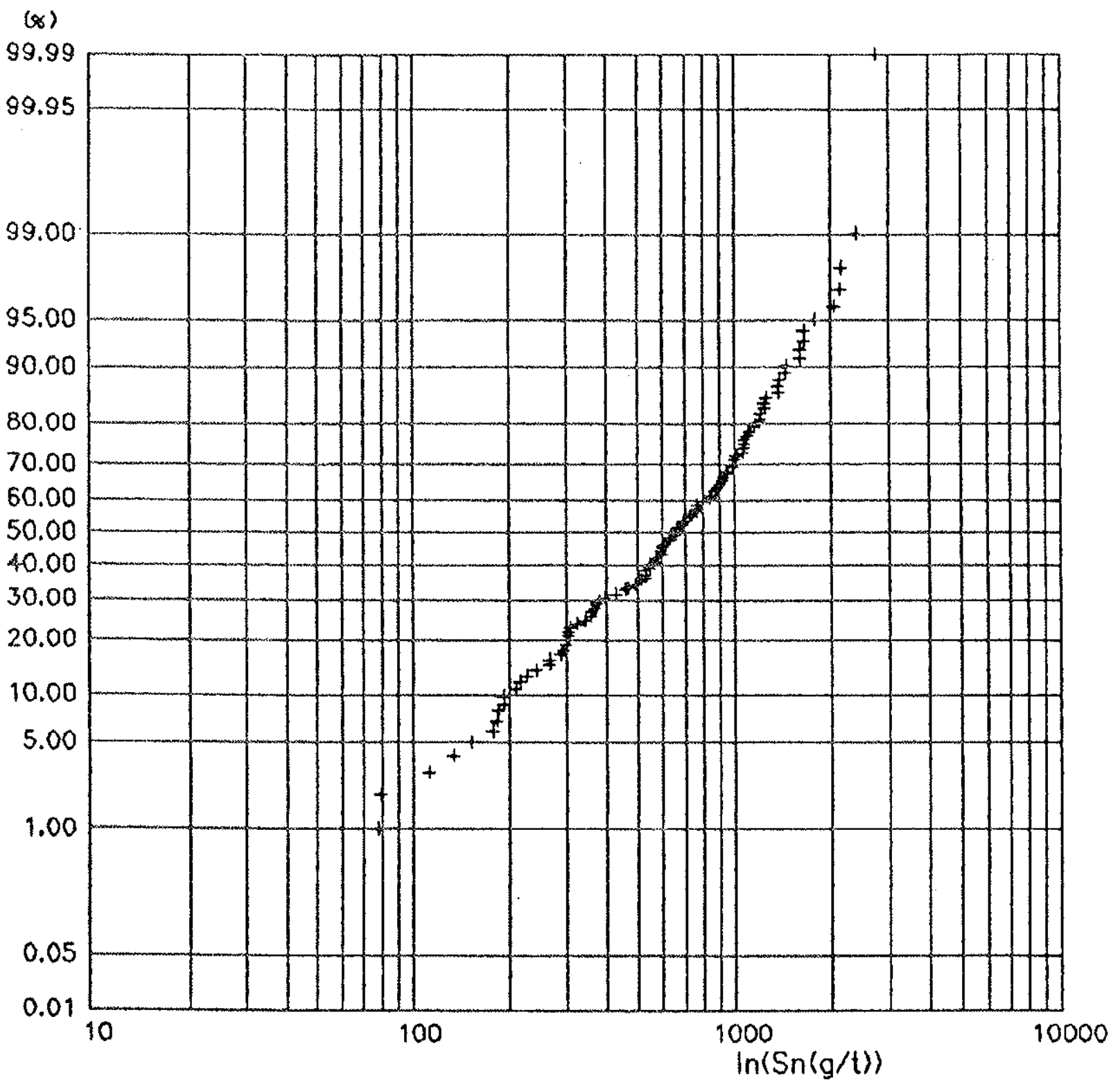

Figura 30: Curva acumulativa em escala de log probabilidade aritmética dos teores de estanho dos avamços das galerias.

\subsection{Parâmetros estatísticos}

A descrição numérica da distribuição de frequência obtida pode ser feita através dos parâmetros estatísticos: média, desvio padrão, assimetria, curtose e coeficiente de variação.

A média é uma medida de tendência central da distribuição de freqüências e representa o valor mais provável de ocorrência. 
A noda e mediana, respectivamente classe do valor mais freqüente e valor a $50 \%$ da distribuição, também são medidas de tendência central, que coincidem com a média, onde a distribuição for perfeitamente normal.

Embora existam três medidas de tendência central, utiliza-se da média, que é uma medida mais robusta de tendência central.

A média é calculada como:

$$
\bar{X}=\frac{1}{N} \cdot \sum_{i=1}^{N} X_{i}
$$

Com a ressalva de que todas as amostras têm igual probabilidade de ocorrência $(1 / n)$.

O desvio padrão é a medida de dispersão associada à tendência central e pode ser interpretada como um indicador da qualidade dos dados num processo industrial (Ex: teores de alimentação de uma usina) ou então um indicador da dispersão natural dos elementos na jazida (p.ex. variabilidade natural dos depósitos minerais).

O desvio padrão pode ser calculado como:

$$
S=\sqrt{\frac{1}{N} \sum_{i=1}^{N}\left(X_{i}-\bar{X}\right)^{2}}
$$

A assimetria é a medida do coeficiente de assimetria da distribuição de freqüencia, e é calculada em torno do $3^{\circ}$ momento da média.

$$
C A=\frac{1}{N} \frac{\sum_{i=1}^{N}\left(X_{i}-\bar{X}\right)^{3}}{S^{3}}
$$

A curtose é uma medida do grau de achatamento da curva de distribuição de freqüência, e é calculada a partir do $4^{\circ}$ momento em torno da média:

$$
C C=\frac{1}{N} \frac{\sum_{i=1}^{N}\left(X_{i}-\bar{X}\right)^{4}}{S^{4}}
$$

O coeficiente de variação dado pela razão entre o desvio padrão e a média também é uma medida de dispersão, porém tem a vantagem de ser adimensional, podendo, por isso, ser expresso em porcentagem. 


$$
C V=\frac{S}{\bar{X}}
$$

Para os conjuntos de dados em estudo, os parâmetros estatísticos encontram-se na Tabela 11.

Tabela 11: Parâmetros estatísticos das distribuiçốes de frequiências dos dados de estanho nos furos e avanços.

\begin{tabular}{|lcc|}
\hline PARAMETROS ESTATISTICOS. & FUROS & AVANÇOS \\
\hline Média & $341 \mathrm{ppm}$ & $792 \mathrm{ppm}$ \\
Variâncià & $502520 \mathrm{ppm}^{2}$ & $301542 \mathrm{ppm}^{2}$ \\
Desvio Padrão & $708 \mathrm{ppm}$ & $549 \mathrm{ppm}$ \\
Assimetria & 0.04 & 0.01 \\
Curtose & 0,24 & 0.04 \\
Coeficiente de Variação & 2.08 & 0.69 \\
no de amostras & 115 & 101 \\
\hline
\end{tabular}

Comparando-se os valores obtidos, verifica-se que o teor médio dos furos foi igual a 341 ppm de estanho, enquanto o teor médio nos avanços foi igual a $792 \mathrm{ppm}$ de estanho.

Somente para fins de ilustração, são apresentados, na Figura 31, os histogramas dos dados de estanho nos furos e nos avanços, desenhados numa mesma escala, mostrando principalmente as diferenças nos teores médios.

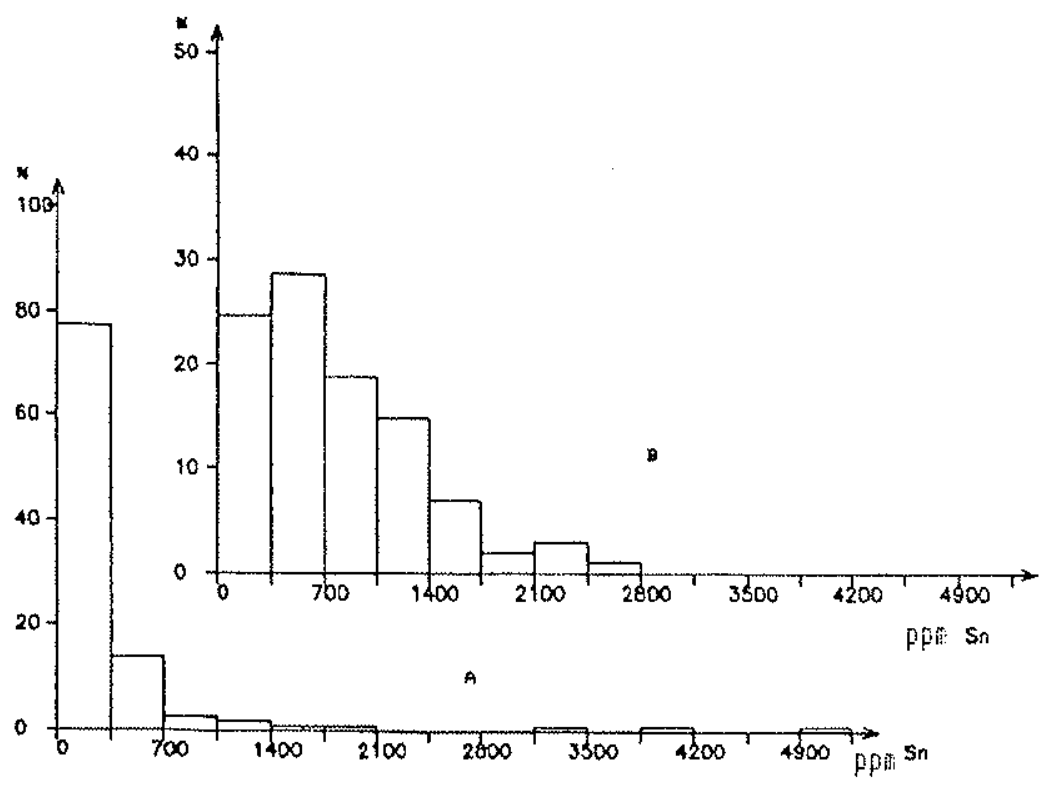

Figura 31: Histogramas das distribuções de freqü̂̀ncias dos teores de estanho nos testemmhos (A) e nos avanços das galerias (B). 
A grande diferença entre teores médios é atribuida aos processos de amostragem, pois os volumes amostrados nos furos foram em média 3300 vezes menores que os volumes amostrados nos avanços. Se esta constatação foi verdadeira ela deve ser acompanhada também da redução da variância dos furos para os avanços, mantendo-se a relação fundamental da amostragem volume $x$ variância $=$ constante.

Na Tabela 11, verifica se a redução da variância de $502520 \mathrm{ppm}^{2}$ nos furos para 301542 $\mathrm{ppm}^{2}$ nos avanços. O coeficiente de variação é muito menor nas amostragens de maior volume do que nos testemunhos de sondagem, como se observa na mesma tabela.

Uma importante conclusão deste estudo é que, na pesquisa de cassiterita em pegmatitos, que apresentam esta grande variabilidade natural, o processo de amostragem é de vital importância, pois, se o teor de corte praticado à época fosse igual a $500 \mathrm{ppm}$ de estanho, o teor médio obtido nos furos (340 ppm) não encorajaria a continuidade da pesquisa. Assim, neste caso, somente a amostragem volumétrica pôde demonstrar a viabilidade econômica deste depósito, embora a abertura de trabalhos subterrâneos seja mais onerosa. 


\section{CAPítulo 8}

\section{REVISÃO DOS MÉTODOS CLÁSSICOS DE AVALIAÇÃO DE RESERVAS}

A avaliação de reservas de depósitos minerais seguiu, no princípio, os métodos de cálculo semelhantes àqueles praticados na construção de estradas e na remoção de terra. Posteriormente, essa avaliação baseou-se em critérios intuitivos, experimentais ou práticos, aprimorando-se, no decorrer dos tempos, tanto com base no aumento do conhecimento dos tipos de depósitos minerais, quanto da amostragem ou das técnicas de mineração.

Popoff (1966), no entanto, procurando sistematizar e padronizar a terminologia e os métodos de cálculo, propôs uma revisão e análise desses métodos de cálculo de reserva. As suas proposições fundamentaram-se nos princípios de interpretação de variáveis entre dois pontos contínuos de amostragem, os quais configuram e subdividem o depósito mineral em blocos ou segmentos geométricos com grau de confiabilidade variável.

Estes princípios são os seguintes:

- os valores de uma variável de interesse (teor, espessura, densidade, etc) mudam gradual e continuamente ao longo de uma reta entre dois pontos de amostragens adjacentes (mudanças graduais ou lei das funções lineares);

- o valor da variável de interesse em um ponto não amostrado é igual àquele do ponto mais próximo (princípios dos pontos próximos ou esfera de igual influência);

- os valores conhecidos nos pontos de amostragem podem ser extrapolados segundo critérios geológicos ou por correlação com depósitos similares (princípio da generalização).

Da aplicação desses princípios, dos teores ou teores médios atribuídos aos compartimentos individuais ou ao total do depósito resulta a reserva calculada.

Pautado nesses princípios, Popoff expõe os métodos clássicos ou convencionais para avaliação de reservas em quatro grupos:

a) no Grupo 1, o Método dos Blocos Análogos supõe que alguns segmentos ou blocos do corpo mineral em estudo possuam similaridade geológica e tecnológica com outras porções do mesmo depósito ou depósitos semelhantes, fazendo-se uso dos fatores médios e estatísticos para cálculo de reservas em blocos ou de todo o depósito.

Os fatores médios são representados pelas médias aritméticas dos elementos básicos (teor, espessura e densidade) e sua precisão depende da qualidade, quantidade, densidade e distribuição 
das observações. Os depósiios regulares apresentam características mais homogêneas. $\mathrm{O}$ fator estatístico é o valor médio estatístico, expresso em porcentagem do constituinte ou dos valores recuperados por unidade de área, peso ou volume. Ele pode também ser baseado em dados de produção, em dados históricos ou de porções do dẹpósito ou até de depósitos similares. Esses fatores são muito usados, na prática, para o cálculo de reservas potenciais de uma mina ou distrito e, sua precisão, depende da interpretação geológica do depósito mineral.

A base deste método é a extensão da característica média determinada ou da característica média estatística de depósitos regulares (teor ou espessura), de modo que a extensão dos fatores médios ou estatísticos, por analogia, não esteja sujeita a grandes erros de estimativa.

A Figura 32, segundo Popoff (1966), mostra esquematicamente o cálculo de reservas pelo método exposto. Nesta figura tem-se a área delimitada pelos furos mineralizados, a qual multiplicada pela espessura média e teor médio resultará na reserva procurada.

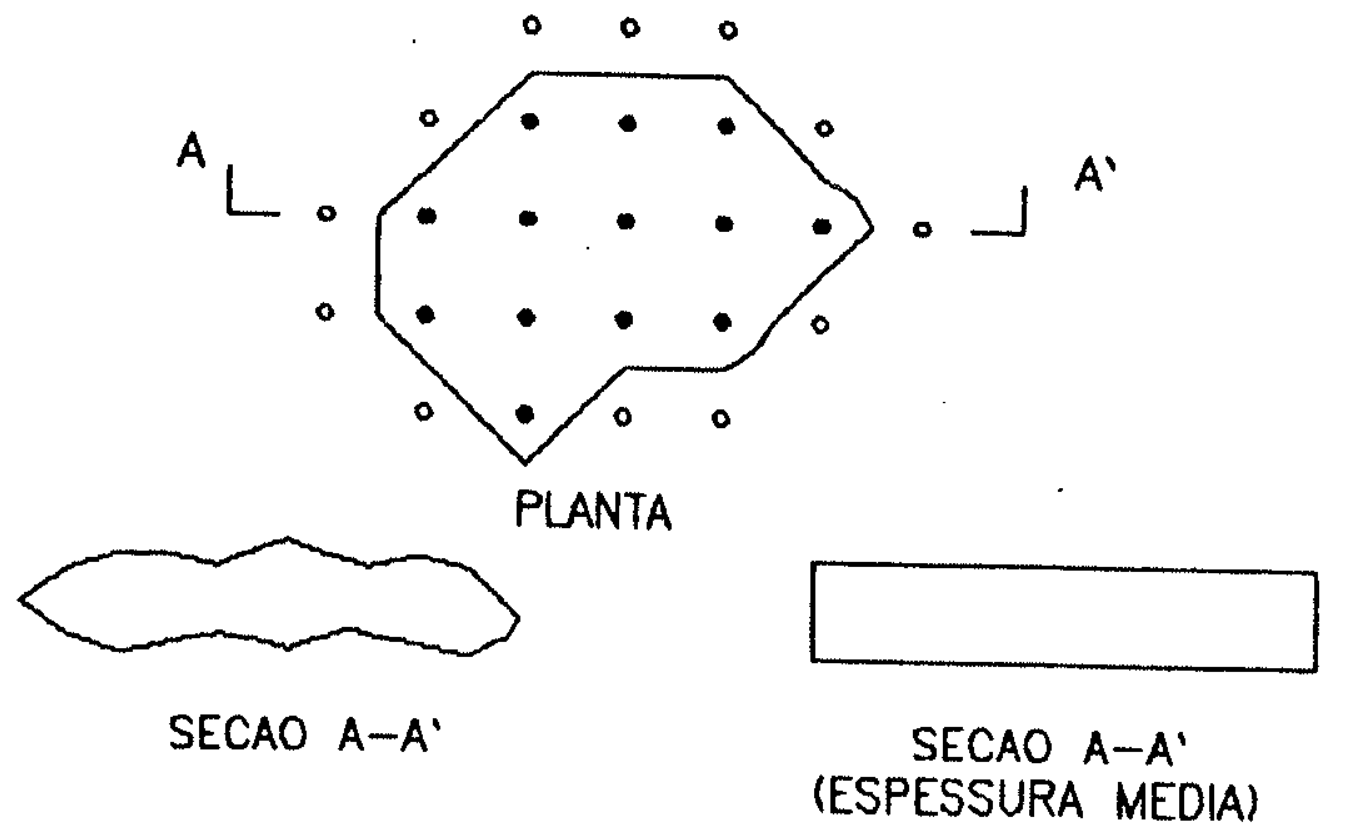

Figura 32: Procedimento de cálculo de reservas pelo método dos blocos análogos (Popoff, 1966). 
b) no Grupo 2, o Método dos Blocos de Lavra pode ser definido como o método utilizado, para determinar a reserva do depósito pela acumulação das reservas parciais obtidas num certo bloco do depósito (Figura 33), delimitado por trabalhos de pesquisa e/ou desenvolvimento subterrâneo e por considerações geológicas e econômicas. De acordo com o próprio nome, esse é um método específico à lavra subterrânea (a forma mais comum do bloco de lavra é o paralelepípedo).

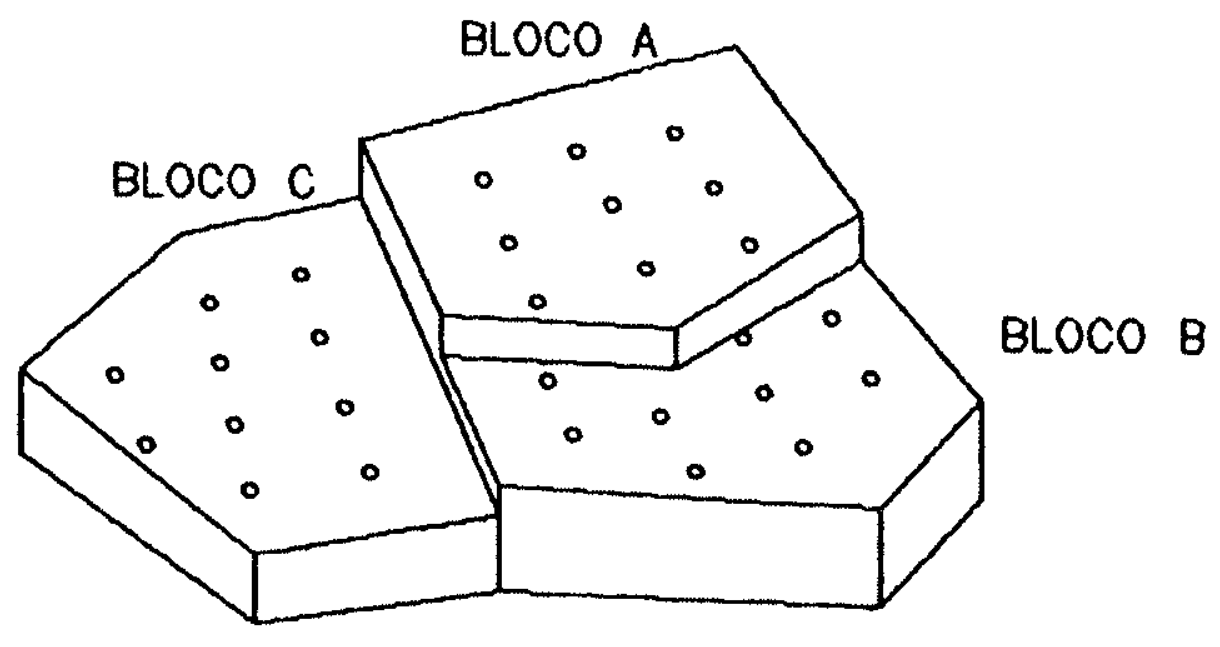

Figura 33: Subdivisão em blocos, segundo suas caracteristicas geológicas (Popoff, 1966).

c) no Grupo 3, o Método dos Perfis pressupõe a possibilidade de subdividir o depósito em blocos por meio de seções ou plantas geológicas situadas a intervalos constantes ou não, perpendiculares à direção do depósito ou a diferentes níveis, dependendo da densidade dos trabalhos de pesquisa.

Conforme o modo de construção dos blocos, esse método pode ser subdividido em outros três :

- método dos perfis padrão: baseado nos princípios das mudanças graduais (Figura 34). Cada bloco interno do depósito é delimitado por duas seções de amostragem e por uma superficie lateral irregular, e cada bloco da extremidade por uma única seção amostrada, sendo o comprimento, via de regra, igual à metade da distância desta seção com outra contígua. Estas seções podem ser paralela ou não, vertical, horizontal ou inclinada;

- método dos perfis lineares: baseado no princípio dos pontos mais próximos (Figura 35). Cada bloco é definido por uma seção e um comprimento igual à meia distância entre as seções adjacentes; 
- método das isolinhas: baseado no princípio de que os valores da variável de interesse variam gradual e continuamente dentro da fronteira dos dados, conforme ilustrado pela Figura 36.

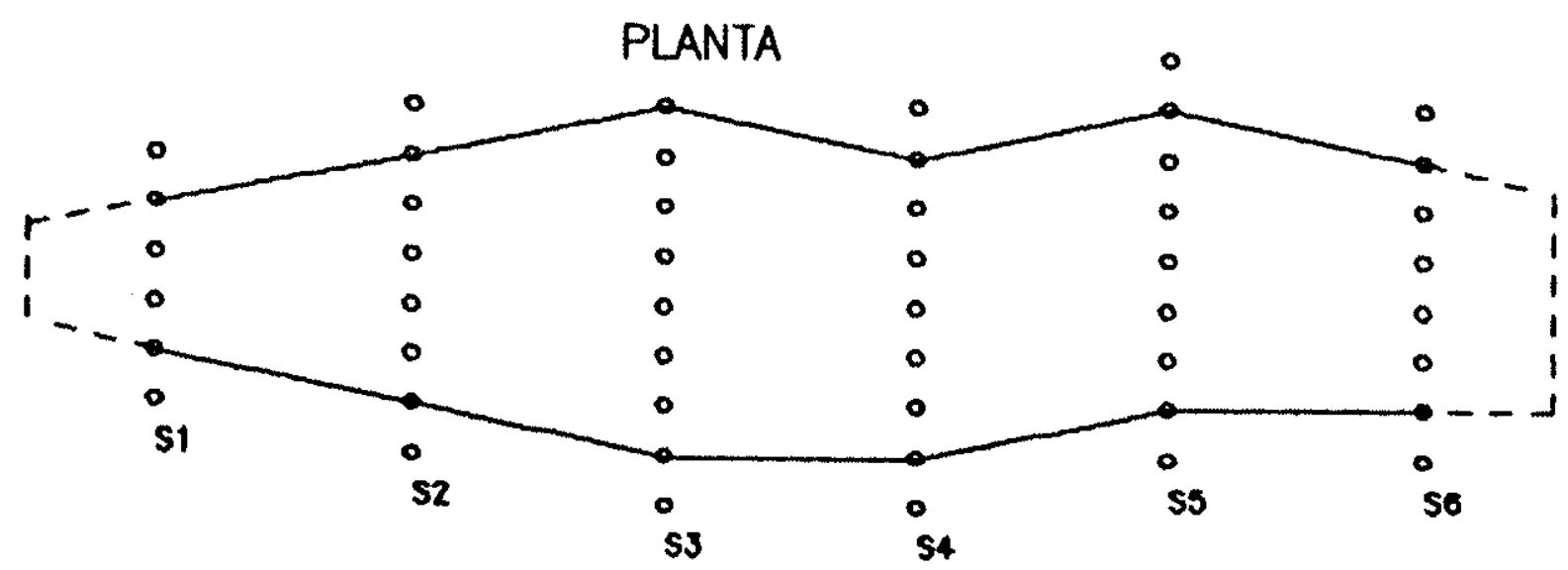

Figura 34: Subdivisão em blocos pelo método dos perfis padrão (Popoff, 1966).

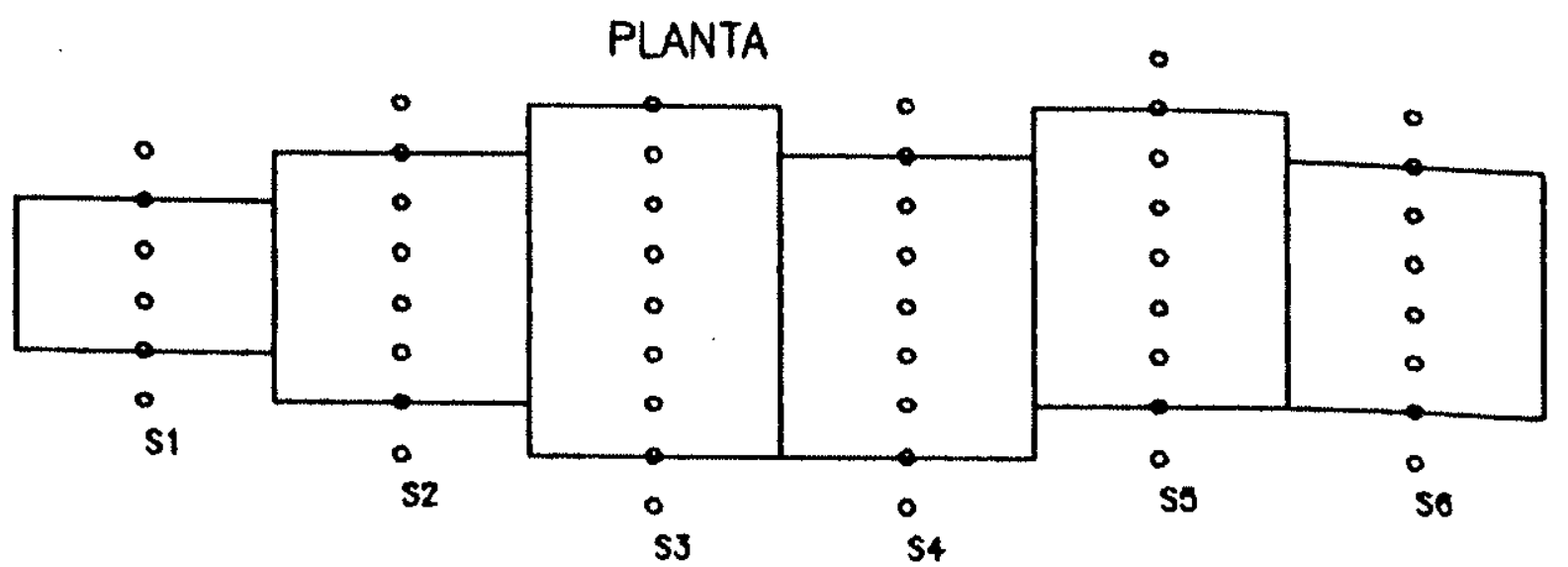

Figura 35: Subdivisão em blocos pelo método dos perfis lineares (Popoff, 1966).

d) no Grupo 4, encontram-se os métodos analíticos que, aplicados os princípios de interpretação, permitem avaliar reservas em blocos de formas geométricas simples com prismas de 
seções triangular ou poligonal. Este método ainda é conhecido como método dos triângulos ou método dos polígonos, dependendo da subdivisão obtida no corpo de minério.

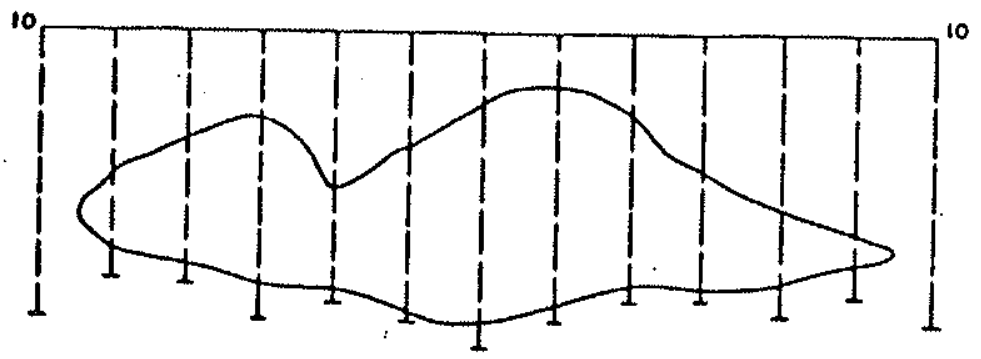

(4)

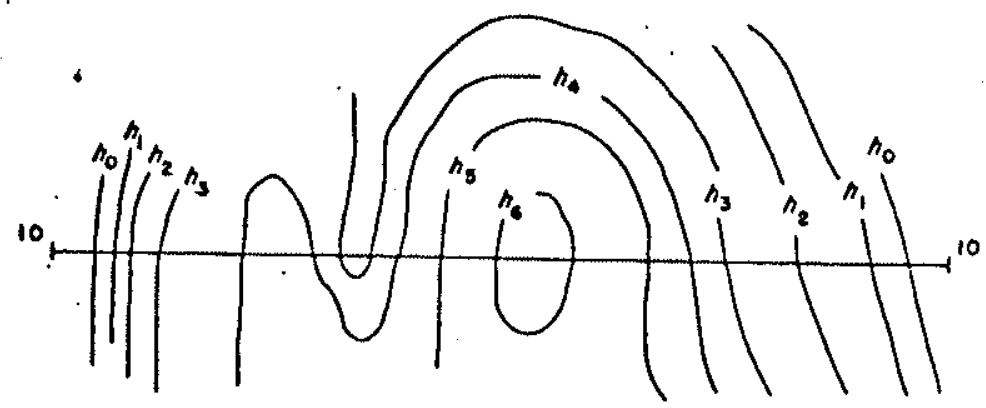

(B)

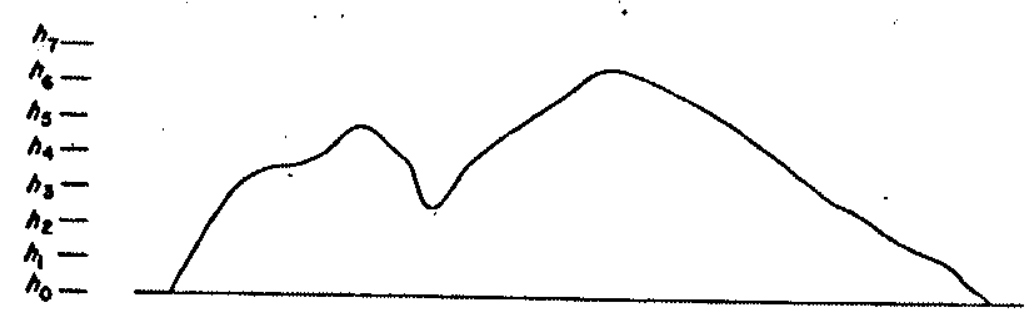

(C)

Figura 36: Método das isolinhas numa linha de pesquisa 10-10: "A", perfil de um corpo mineral; " $B$ ", planta de isópacas do mesmo corpo; " $C$ ", perfil construido a partir da planta de isópacas "B" (Popoff, 1966).

O método dos triângulos é baseado no princípio das mudanças graduais entre duas estações adjacentes que, sucessivamente unidas, geram uma malha triangular. Cada triângulo representa a base de um prisma triangular e as arestas um atributo (espessura, teor, acumulação, etc) do bloco. Assim, o depósito mineral é substituído como um todo por blocos prismáticos de base triangular. Os serviços de pesquisa (poços ou furos) podem estar distribuidos de modo regular ou irregular; no primeiro caso, cada furo central compartilhará o valor do atributo investigado até oito vezes, ao passo que, na distribuição irregular, cada furo campartilhará o valor de seu atributo com os furos ao redor.

Conforme descrito por Popoff (1966), a união das estações sem regras claras pode conduzir a configurações de triângulos diferentes, quando executada por pessoas diferentes, 
conforme a Figura 37. Assim, sugere que, além de subdividir o depósito mineral no maior número possível de rriângulos, que eles sejam equiláteros e os círculos circunscritos os menores possiveis. Entretanio, segundo Yamamoto \& Bettencourt (1992), esta regra de Popoff (1966) continua subjetiva, pois está sujeita a várias interpretações. Assim, considera-se a "Triangulação de Delaunay", descrita por Pettinati (1983), satisfatória, pois resulta numa única malha triangular. Segundo Pettinati (1983), a triangulação é feita a partir da "Divisão de Dirichlet", onde em torno de cada ponto de amostragem é construído um polígono convexo, de tal modo que dois polígonos contíguos possuam em comum uma única aresta, que seja equidistante dos pontos internos aos referidos poligonos, como pode ser observado na Figura 38.
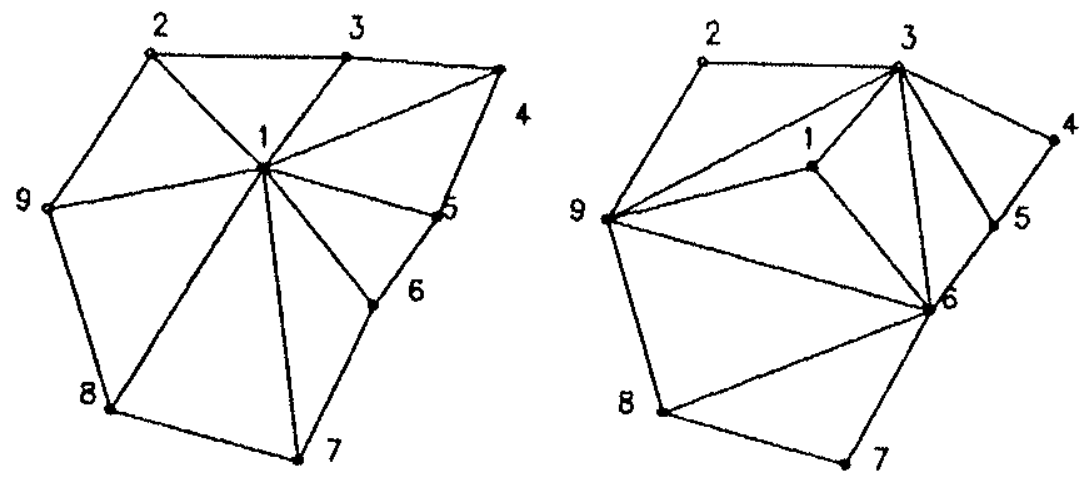

Figura 37: Configurações de triângulos diferentes para um mesmo conjunto de dados, segundo Popoff (1966).
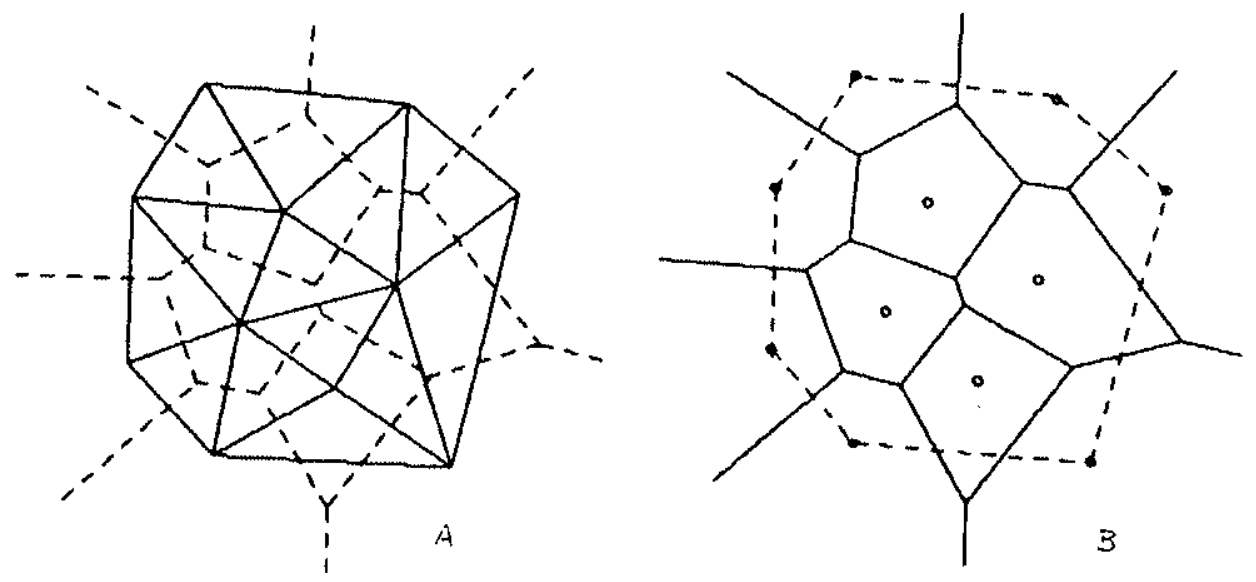

Figura 38: (A) - "Triangulação de Delaumay" e (B) - "Divisão de Dirichlet", segundo Pettinati (1983).

Esse método de avaliação de reservas não considera a geologia e as características minerais do depósito. Recomenda-se a utilização para grandes corpos sedimentares e depósitos 
disseminados em geral, quando avaliados por malha regular. No entanto, quando as variáveis estudadas (por exemplo: o teor) decrescem do centro para a borda, este método não deve ser utilizado (Garcia Guerra, 1988).

Por outro lado, existem desvantagens como:

- caso os triângulos não sejam equiláteros, os valores devem ser ponderados não somente com a espessura de cada furo, como também pelos ângulos dos triângulos, comprimento dos lados, distância de cada furo do centro de gravidade e respectivas áreas de influência;

- um furo pode participar de vários triângulos, se estiver no interior do corpo, ao passo que os da periferia participam apenas de dois;

- teores ou espessuras elevados ou baixos podem ficar mascarados, se se considerar o valor médio dos três furos.

O método dos polígonos está fundamentado no princípio dos pontos mais próximos aos pontos de dados distribuídos em uma área onde se obtém uma rede de poligonos, cujos lados se encontram a meia distância entre duas estações adjacentes.

Estabelecendo as vantagens, aplicações e desvantagens desse método, Garcia Guerra (1988) assim se manifestou a respeito dele:

1 - este método pode ser usado para cálculos preliminares de reservas, porque os cálculos são simples e rápidos; fornece resultados bastante satisfatórios quando existe continuidade da mineralização, com variações graduais, malha regular e inúmeros trabalhos. Em contrapartida, esses resultados nem sempre são satisfatórios, principalmente quando os valores observados apresentam extremos.

2 - este método se fundamenta em considerações mais teóricas do que geológicas e minerais, e sua utilização faz-se em corpos tabulares (camadas, veios espessos) e grandes lentes. Ele não deve ser usado em depósitos cujos furos não possam ser bem correlacionados, nem em corpos pequenos e de distribuição errática. No caso de malhas de pesquisa irregulares com furos inclinados e de diferente profundidade, é praticamente impossivel determinar a forma, e conseqüentemente o volume mineralizado dos polígonos.

Quanto à construção destes poligonos, a "Divisão de Dirichlet" descrita anteriormente no Método dos Triângulos é a mais recomendada.

Por ter sido utilizado o Método dos Perfis Padrão na quantificação da reserva Xupé, as recomendações clássicas desse Método serão expostas com maiores detalhes.

Segundo Yamamoto \& Bettencourt (1992), para o cálculo de reservas pelo Método dos Perfis Padrão os procedimentos usuais são os seguintes: 

a) cálculo da área de todàs as seções;
b) cálculo dos teores médios por seção;
c) cálculo do volume e tonelagem de metal/minério para cada bloco e,
d) resumo dos resultados de todos blocos e cálculo do teor médio global.

A área é calculada pela regra dos trapézios, isto é, a seção é subdividida por "n" trapézios verticais separados por uma distância constante, conforme a Figura 39, mediante a seguinte fórmula:

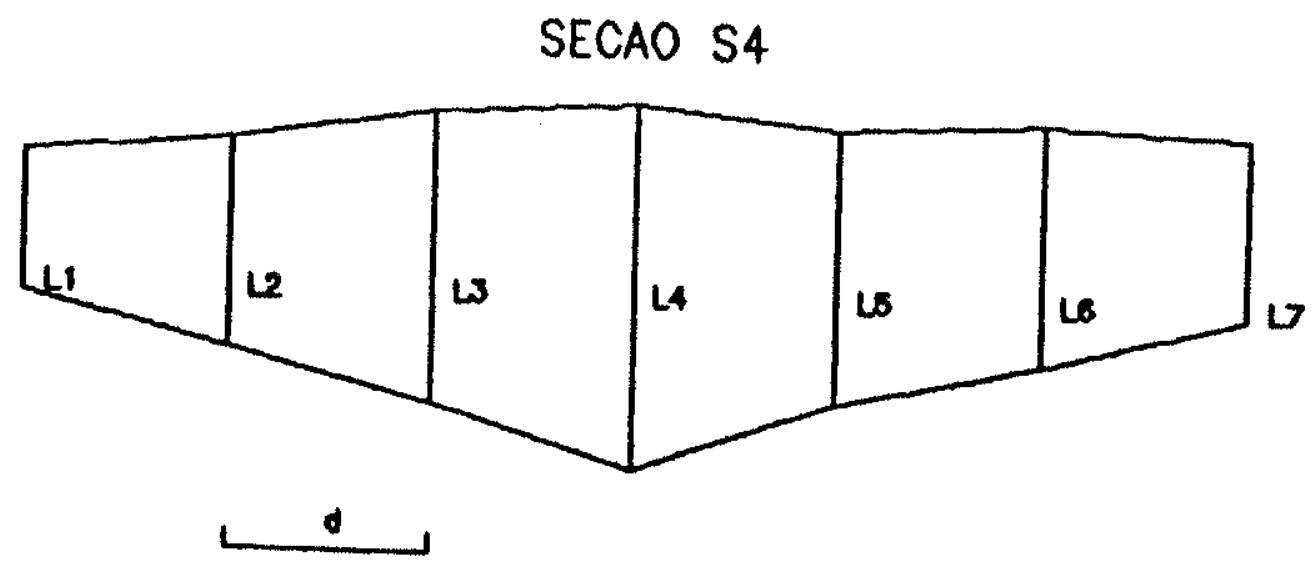

\section{$\operatorname{areo}=d l(L 1+L 7) / 2+L 2+L 3+L 4+L 5+L 61$}

Figura 39: Desenho da seção $S_{4}$ da Figura 34, ilustrando o procedimento de cálculo da área pela regra dos trapézios.

$$
V=\frac{\alpha}{\operatorname{sen} \alpha} \frac{\left(S_{1}+S_{2}\right)}{2} \frac{\left(h_{1}+h_{2}\right)}{2} a=d\left[\frac{\left(l_{1}+l_{n}\right)}{2}+l_{2}+l_{3}+\cdots+l_{n-1}\right]
$$

onde "li "é o lado do i-ésimo trapézio; e

"d" é a distância entre os lados dos trapézios.

O teor médio para cada seção pode ser determinado pelos princípios das mudanças graduais, pelo princípio dos pontos mais próximos (pela média ponderada com a espessura e média ponderada com a área), e como uma média aritmética. No caso da distribuição irregular de trabalhos, há uma relação direta ou inversa entre espessura e teor, e o teor médio pode ser calculado como a média ponderada da espessura. Determina-se inicialmente o teor médio por furo como média dos teores dos intervalos poderados pelas espessuras e, em seguida, o teor médio da seção média dos teores médios por furo, ponderados pelas respectivas espessuras: 


$$
t_{m s}=\frac{\sum_{i=1}^{n} t_{m i} \cdot e_{f i}}{\sum_{i=1}^{n} e_{f i}}
$$

O teor médio do bloco é calculado como média dos teores médios por seção, ponderados pelas respectivas áreas:

$$
t_{m b}=\frac{\left(t_{m s 1} \cdot a_{1}+t_{m s 2} \cdot a_{2}\right)}{\left(a_{1}+a_{2}\right)}
$$

A configuração das áreas e a forma lateral dos blocos normalmente são irregulares, e, para cálculo dos volumes pela geometria dos sólidos, as áreas serão consideradas como círculos de igual tamanho ou figuras poligonais; as superficies laterais dos blocos são desconsideradas.

Dessa maneira, a fórmula mais simples de cálculo de volume entre duas seções paralelas com áreas $S_{1}$ e $S_{2}$ e com uma distância perpendicular "L" entre elas é:

$$
V=\frac{\left(s_{1}+s_{2}\right)}{2} \cdot L
$$

Essa fórmula é precisa, quando as duas áreas possuem formas e tamanho muito similares.

Blocos terminais de corpo de minério lenticulado podem ser convertidos em uma pirâmide ou cunha, quando a área maior "S", numa seção, afunila-se para uma linha ou um ponto na seção seguinte (Figura $40 \mathrm{~A}$ ). Caso o bloco afunile para uma linha, o volume é calculado pela fórmula:

$$
V=\frac{S}{2} \cdot L
$$




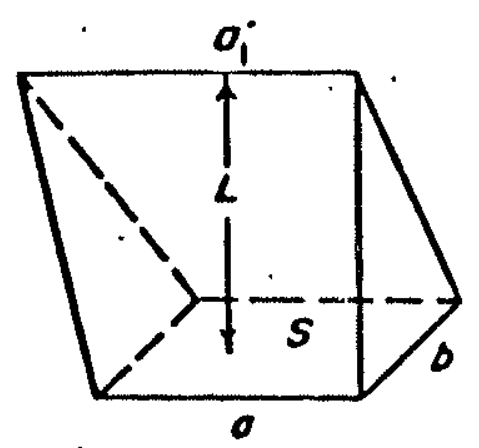

(1)

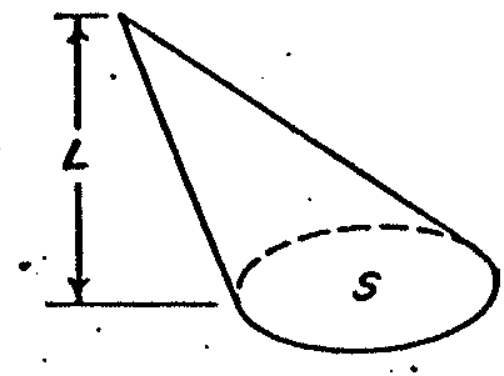

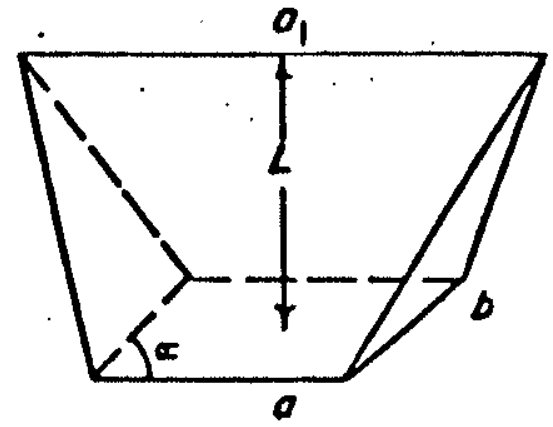

$V=\frac{S}{2} L$

$a=90^{\circ}$

(A)

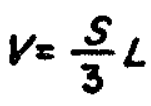

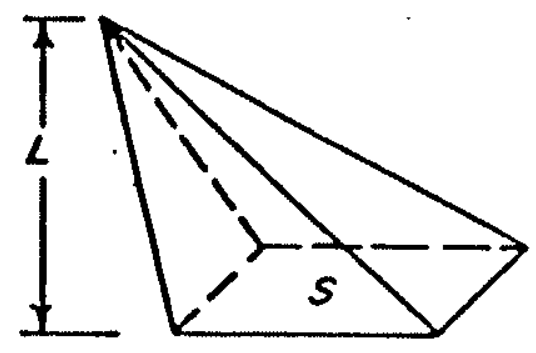

(B)

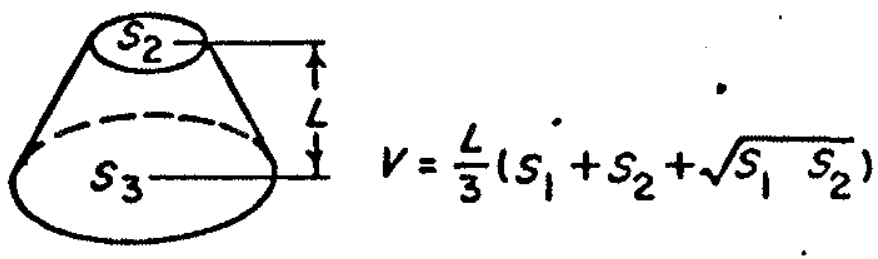

(C)

Figura 40: Método dos perfis padrão: " $A$ " - fórmula comum da pirâmide; "B" - fórmula do cone; "C" fórmula do tronco da pirâmide (Popoff, 1966).

Esta fórmula, no entanto, é precisa somente quando a base é retangular e as faces laterais são triângulos isósceles e trapezoidais. A fórmula mais precisa para cunha é:

$$
V=\frac{L}{6} \cdot\left(2 a+a_{1}\right) b \operatorname{sen} \alpha
$$

onde "a" e "b" são os comprimentos dos lados da base, " $\alpha$ " é o ângulo entre "a" e "b" e "a1" é o lado maior do trapézio (Figura $40 \mathrm{~A}$ ). 
Se o bloco afunila para um ponto (Figura $40 \mathrm{~B}$ ), o volume é calculado pela fórmula do cone:

$$
V:=\frac{S}{3} \cdot L
$$

O volume calculado pela fórmula da cunha é $50 \%$ maior do que o volume calculado pela fórmula do cone.

Quando as áreas $S_{1}$ e $S_{2}$ variam no tamanho, mas são similares (Figura $40 \mathrm{C}$ ), a fórmula do tronco do cone ou pirâmide é usada para calcular o volume do bloco:

$$
V=\frac{L}{3} \cdot\left(S_{1}+S_{2}+\sqrt{S_{1} S_{2}}\right)
$$

Na prática, a fórmula do tronco é evitada por causa das complicações com o cálculo da raiz quadrada e, em certos casos, é menos precisa do que a fórmula do prisma. Ela é imprecisa nos corpos acunhados. Assim, quando as áreas delineadoras de blocos acunhados truncados tiverem lados iguais, tal como a altura entre dois níveis, ou espessura entre seções paralelas, a fórmula da área média é mais precisa do que a do tronco.

Muitos corpos minerais distendem-se, comprimem-se, reduzem-se, e, no geral, têm superficies laterais que podem influenciar profundamente na precisão do cálculo do volume. A fórmula prismoidal é baseada na hipótese de que a inclusão de superficies laterais, curvadas e empenadas podem ser substituídas com precisão por triângulos, trapézios, ou paralelogramas limitados por linhas retas e construídas a partir de uma seção paralela para uma contígua. A seleção das figuras planas é controlada pela forma do corpo mineral e pela superficie incluida.

A fórmula prismoidal é expressa por:

$$
V=\frac{L}{6}\left(S_{1}+4 M+S_{2}\right)
$$

onde " $\mathrm{M}$ " é a área do plano de um perfil auxiliar paralelo colocado a meia distância das seções $\mathrm{S}_{1}$ e $S_{2}$. A construção desta seção auxiliar é baseada na interpolação de seções longitudinais e em perfil, e pela interpretação da geologia do corpo mineral. Somente em casos excepcionais "M" é uma média de $S_{1}$ e $S_{2}$. A construção de perfis auxiliares requer trabalhos adicionais.

Esta fórmula é vantajosa quando um corpo mineral é dividido dentro de blocos por uma série de perfis pouco espaçados; é também recomendada quando os perfis são de configurações diferentes e se pretendem cálculos mais precisos. Comumente ela é usada na engenharia civil para trabalhos de terraplanagem. 
O Método dos Perfis Padrão para seções não paralelas, segundo Popoff (1966), apresenta as fórmulas para cálculo de reservas considerando que algumas seções construídas ao longo das linhas de exploração podem convergir ou divergir por causa das mudanças de atitude do corpo mineral. $O$ ângulo entre as seções e as linhas de exploração podem variar de cblíquo até obtuso, conforme a variação de atitude.

Para ângulos menores do que $10^{\circ}$, a reserva é calculada pela seguinte fórmula:

$$
V=\frac{\left(S_{1}+S_{2}\right)}{2} \frac{\left(h_{1}+h_{2}\right)}{2}
$$

onde $S_{1}$ e $S_{2}$ são as áreas do corpo mineral na seção, e "h $1 "$ e "h${ }_{2}$ " são os comprimentos perpendiculares dos dois respectivos pontos de centro de gravidade numa e noutra seção, conforme demonstra a Figura 41.

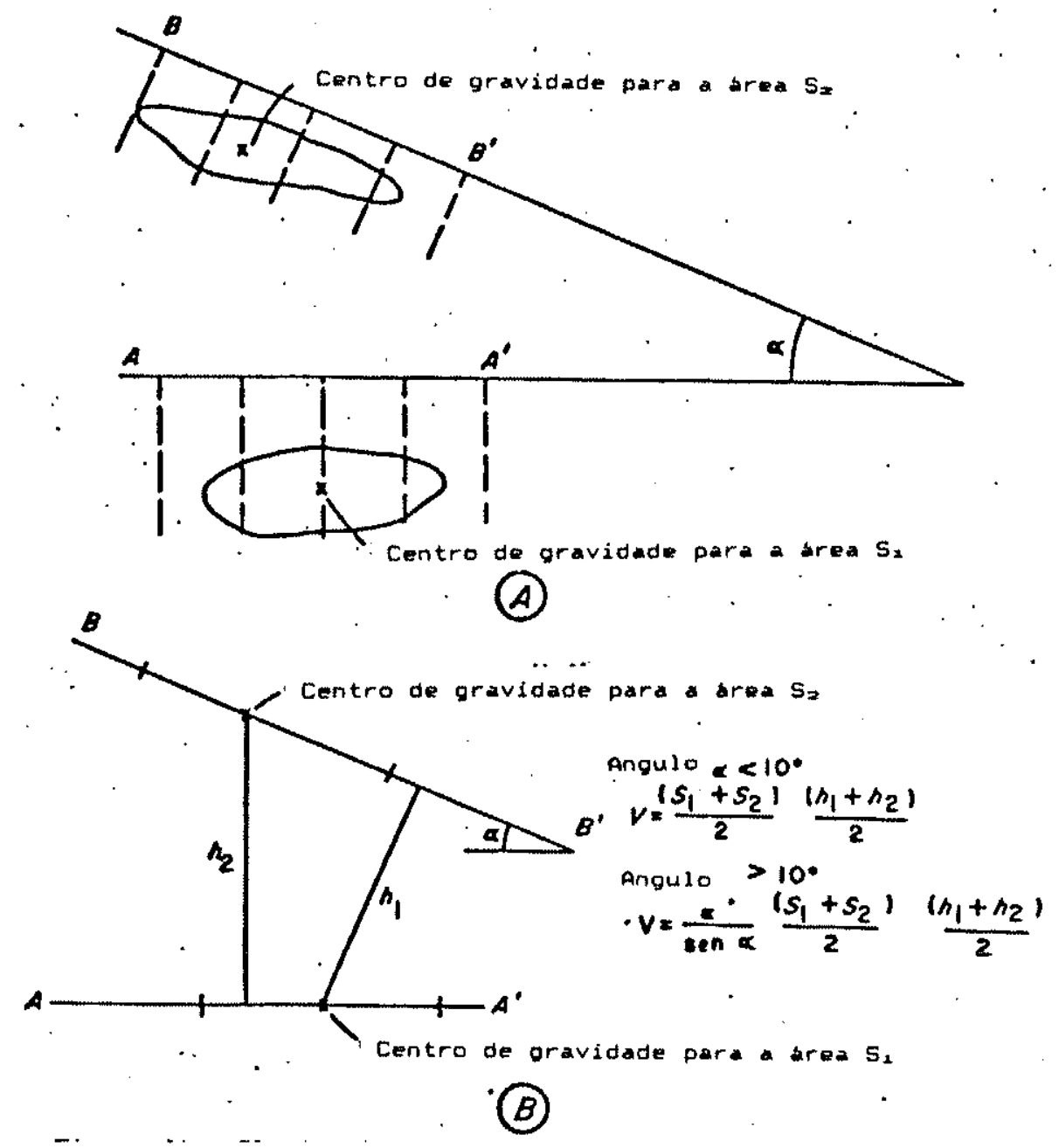

Figura 41: Método dos perfis padrão para cálculo do volume de seções não paralelas. " $A$ " - é a representação gráfica de um corpo mineral interseptado por seções não paralelas; " $B$ " construção em planta das perpendiculares " $h_{I}$ " e " $h_{2}$ " a partir do centro de gravidade de uma seção para outra (Popoff, 1966). 
Na prática, a reserva calculada pela fórmula anterior desvia-se muito pouco da fórmula da área média e, na maioria dos casos, ela não é utilizada para blocos entre seções com um ângulo de interseção menor do que $10^{\circ}$.

Para ângulos maiores do que $10^{\circ}$ é usado o fator de correção $\frac{\alpha}{\operatorname{sen} \alpha}$ na fórmula:

$$
V=\frac{\alpha}{\operatorname{sen} \alpha} \frac{\left(S_{1}+S_{2}\right)}{2} \frac{\left(h_{1}+h_{2}\right)}{2}
$$

onde o ângulo entre as seções é expresso em radianos.

Esta fórmula e os procedimentos são considerados precisos, quando o tamanho da área das seções não difere mais do que 4 a 6 vezes. Elas requerem a localização do centro de massa de cada área, o que é dificultado nas figuras geométricas complexas. $O$ melhor procedimento para localização do centro de gravidade é gráfico.

Os valores dos volumes e tonelagens obtidos nos cálculos de seções paralelas, comparados com aqueles das fórmulas não paralelas, podem mostrar diferenças apreciáveis; para o teor médio, no entanto, é relativamente pequena.

No geral, algumas das vantagens e desvantagens da utilização do Método dos Perfis, reportadas por Popoff (1966) e Garcia Guerra (1988), são as seguintes:

- a) Vantagens:

- o Método dos Perfis retrata graficamente a geologia do depósito mineral;

- o procedimento geral é simples e rápido, mas a precisão da maioria das fórmulas produzidas pode exigir uso de diagramas, cálculos adicionais, forma e tamanho dos corpos mineralizados, etc. É normal utilizar planímetro para determinação da área mineralizada da seção; 


\section{CAPítulo 9}

\section{CÁlCULO DE RESERVAS DO PEGMATITO XUPÉ}

A avaliação de reservas do Pegmatito Xupé apresentada neste trabalho segue a seqüência de critérios e cálculos estabelecido por Bettencourt (1985).

\subsection{Documentos básicos para cálculo das reservas}

Os parâmetros básicos utilizados para o cálculo das reservas do Depósito Xupé são aqueles constantes dos seguintes documentos:

a - Barcelos, Marília S. 1985 - Relatório Complementar de Pesquisa do Pegmatito Xupé, Monte Alegre de Goiás-GO.

b - Paulo Abib Engenharia S/A, 1983 - Estudos de caracterização tecnológica em amostras de cassiterita primária - Xupé (MOA) - Monte Alegre de Goiás, GO, bem como dos dados de pesquisa superficial e subterrânea, assim discriminados:

c - Mapa Geológico do Xupé Sul à escala 1:1000, com curvas de nível de $2 \times 2 \mathrm{~m}$, conforme Figura 8. Neste mapa estão lançados as posições dos furos de sondagem e perfis transversais correspondentes, além da posição do "shaft"" e projeção das galerias subterrâneas;

d - Onze perfis geológicos transversais ao corpo pegmatítico à escala 1:500 (Anexos de 1 a 11), ostentando os trabalhos mineiros e de garimpagem superficial, geologia e posição dos furos de sondagem. Teores correspondentes de $\mathrm{Sn}, \mathrm{Ta}_{2} \mathrm{O}_{5}, \mathrm{Nb}_{2} \mathrm{O}_{5}, \mathrm{Be}$ (W, Cu, As) dos intervalos mineralizados estão na Tabela 5;

e - Mapa geológico-estrutural da galeria do Xupé à escala 1:200 (Figura 9) no qual foram lançados os limites dos avanços de desmonte e número dos avanços. Os teores de cada avanço compõem a Tabela 6, colunas 5 e 7;

f - Quinze "logs" de quinze furos de sondagem, designados: FXS-02, FXS-01, FXS18 e FXS-03, FXS-10, FXS-09, FXS-07 e FXS-08, FXS-05 e FXS-19, FXS-06, FXS-12 e FXS-1 1, FXS-04, e FXS-20, que não serão apresentados;

$\mathrm{g}$ - Volume das amostras e teores correspondentes de Sn total e $\mathrm{Ta}_{2} \mathrm{O}_{5} \mathrm{em} \mathrm{g} / \mathrm{m}^{3}$ detalhados na Tabela 6, colunas 3, 5 e 7 .

\subsection{Critérios básicos indispensáveis para cálculo das reservas}

Para disciplinar os dados fundamentais indispensáveis ao cálculo de cubagem e definição futura dos parâmetros geométricos ao projeto de lavra, assumimos as seguintes premissas: 
a - Os procedimentos referentes à amostragem das galerias, tratamento das amostras na usina de concentração gravimétrica $\mathrm{e}$ as análises químicas são corretos $\mathrm{e}$ representativos do conteúdo de $\mathrm{Sn}$ total no minério, pelo menos nos domínios da galeria;

b - As informações obtidas nos furos de sondagem em relação aos teores de $\mathrm{Sn}$ e $\mathrm{Ta}_{2} \mathrm{O}_{5}$ são consideradas como simplesmente indicativas dos teores desses elementos e óxidos, uma vez que não há correlação com os teores observados nas amostras volumétricas das galerias;

c - Os teores básicos de $\mathrm{Sn}$ e $\mathrm{Ta}_{2} \mathrm{O}_{5}$ utilizados para cálculo foram aqueles obtidos de amostragem das galerias. Os teores dos furos de sondagem não foram utilizados por não serem representativos em face dos resultados das galerias;

d - Não foram determinados, separadamente, os teores médios ponderados das galerias individuais tampouco os teores médios ponderados de blocos individuais;

e - Por ser impossível utilizar os teores dos furos de sondagem, julgamos mais conveniente determinar o teor médio ponderado global proveniente das amostras das galerias e generalizar esse valor para a totalidade do corpo II do Depósito Xupé;

f - Para o cálculo simples dos teores médios ponderados das 101 amostras, os teores individuais de cada avanço foram ponderados com os respectivos volumes individuais. Os valores médios obtidos, conforme a Tabela 6 , são os seguintes:

$$
\begin{aligned}
& \mathrm{Sn} \text { total }=1567 \mathrm{~g} \mathrm{Sn} / \mathrm{m}^{3} \\
& \mathrm{Ta}_{2} \mathrm{O}_{5}=55 \mathrm{~g} \mathrm{Ta}_{2} \mathrm{O}_{5} / \mathrm{m}^{3}
\end{aligned}
$$

g - Para cálculo estatístico do teor, tanto para $\mathrm{Sn}$ quanto para $\mathrm{Ta}_{2} \mathrm{O}_{5}$, as amostras foram consideradas como variáveis independentes. Visto que, neste tipo de depósito, os teores de $\mathrm{Sn}$ e $\mathrm{Ta}_{2} \mathrm{O}_{5}$ possuem uma distribuição lognormal, acreditamos que os valores estatísticos mais representativos para esses elementos são os seguintes:

$\mathrm{Sn}$ - média aritmética $=1695 \mathrm{~g} \mathrm{Sn} / \mathrm{m}^{3} \mathrm{e}$

$\mathrm{Ta}_{2} \mathrm{O}_{5}-$ média aritmética $=53 \mathrm{~g} \mathrm{Ta} 2 \mathrm{O}_{5} / \mathrm{m}^{3}$

Em função desses valores é que foram calculadas as reservas; h - Para os cálculos de cubagem, o Depósito Xupé foi subdividido em dois corpos, a saber:

Corpo de Minério I, compreendido entre os perfis FXS-02 e Limite Norte $=$ FXS-09+11,5m (Falha);

Corpo de Minério II, correspondente ao volume de minério limitado a norte pelo perfil FXS-04 $+83 \mathrm{~m}$ e a sul pelo perfil FXS-07 $+26 \mathrm{~m}$ segundo o eixo longitudinal do corpo. 
Além desses corpos foi ainda individualizada, nos domínios do corpo de minério II, uma faixa de quartzo leitoso que foi isoladamente cubado como material estéril.

i - Os limites de cubagem, à superficie, são esses já definidos e o limite inferior varia entre os niveis 417 e $478,7 \mathrm{~m}$ para o Corpo II e 505 e $475 \mathrm{~m}$ para o Corpo I;

j - Considerou-se como:

- Minério Medido no Corpo I, o minério situado entre a superficie e as cotas 475 e $505 \mathrm{~m}$, testado, em profundidade, pelos furos de sondagem FXS-02, FXS-01, FXS-03, FXS-10;

- Minério Indicado no Corpo I, o minério correspondente às extremidades norte do corpo e respectivamente definido, em uma só face, pelos furos de sondagem FXS-09 e a Falha;

- Minério Medido no Corpo II, correspondente a todo o minério compreendido entre os perfis FXS-07 e FXS-04 recoberto em profundidade por furos de sondagem, à exceção dos blocos de minério situados abaixo da galeria do Xupé, entre os perfis FXS-05 +53,0 m Sul (Aux-1) e FXS-20 + 4,0 m Norte (Aux-2);

- Minério Indicado no Corpo II, o minério existente abaixo do nível da galeria entre os perfis FXS-05 + 53,0 m Sul e FXS-20 + 4,0 m Norte e que se prolonga em profundidade entre os niveis 417 e $478,7 \mathrm{~m}$, bem como aquele existente nas extremidades do corpo e, respectivamente definidos, em uma só face, pelos furos de sondagem FXS-07 e FXS-04;

Assim, os Quadros de Reservas são os seguintes: 
QUADRO III

DEPOSITO XUPE

CORPO 1 - RESERVA MEDIDA

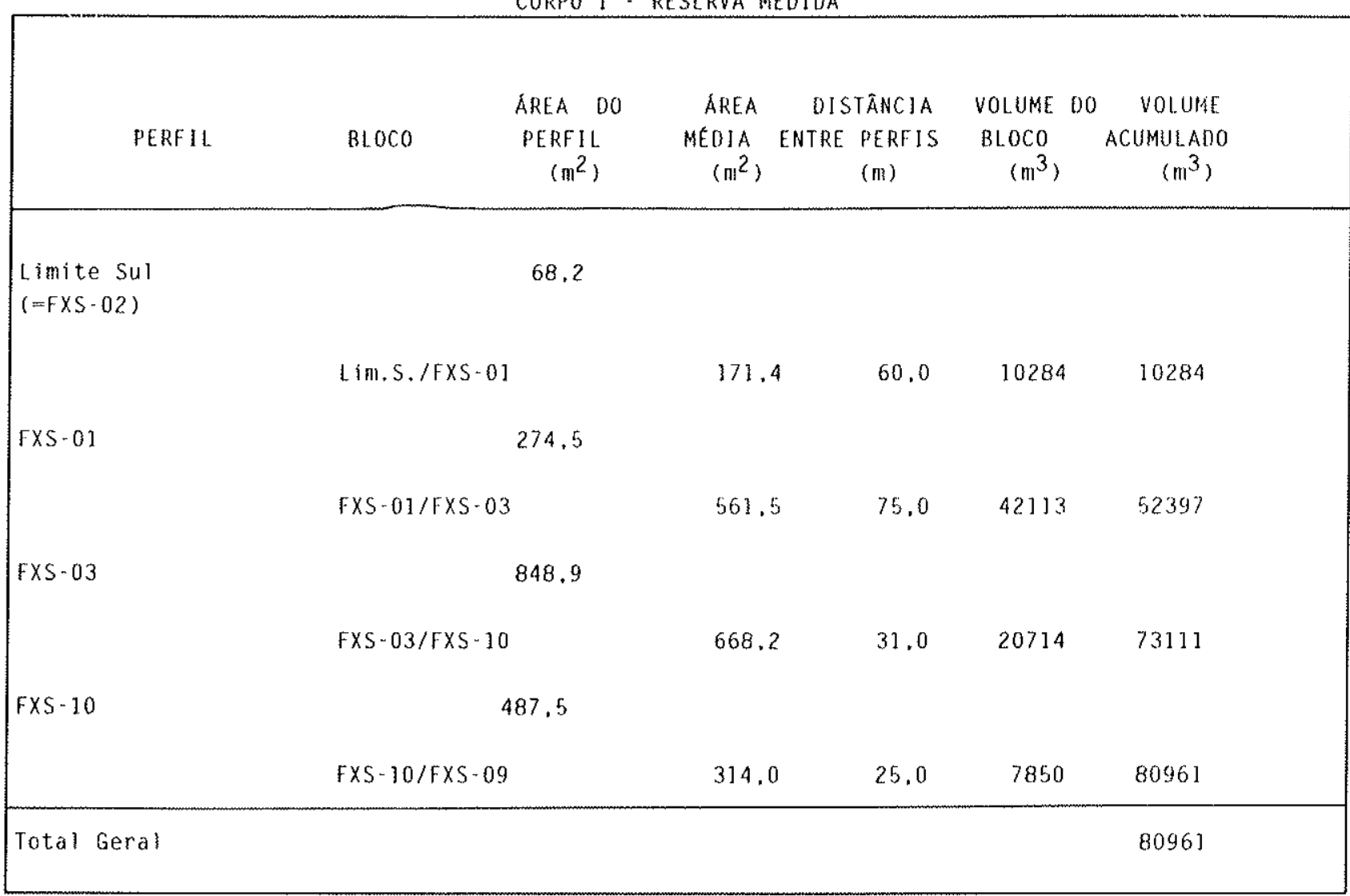

QUADRO IV

DEPOSITO XUPE

CORPO 1-RESERVA INDICADA

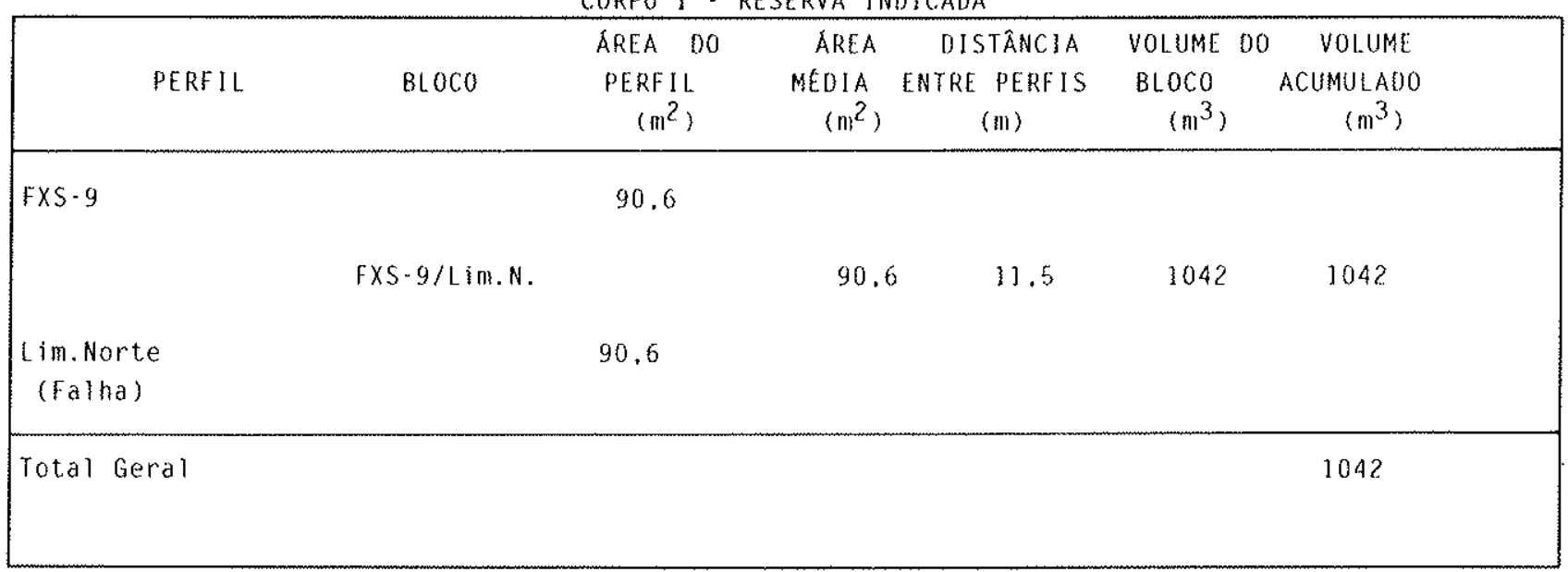


QUADRO $V$

DEDOSITO XUPE

CORPO 11 - RESERVA MEDIDA

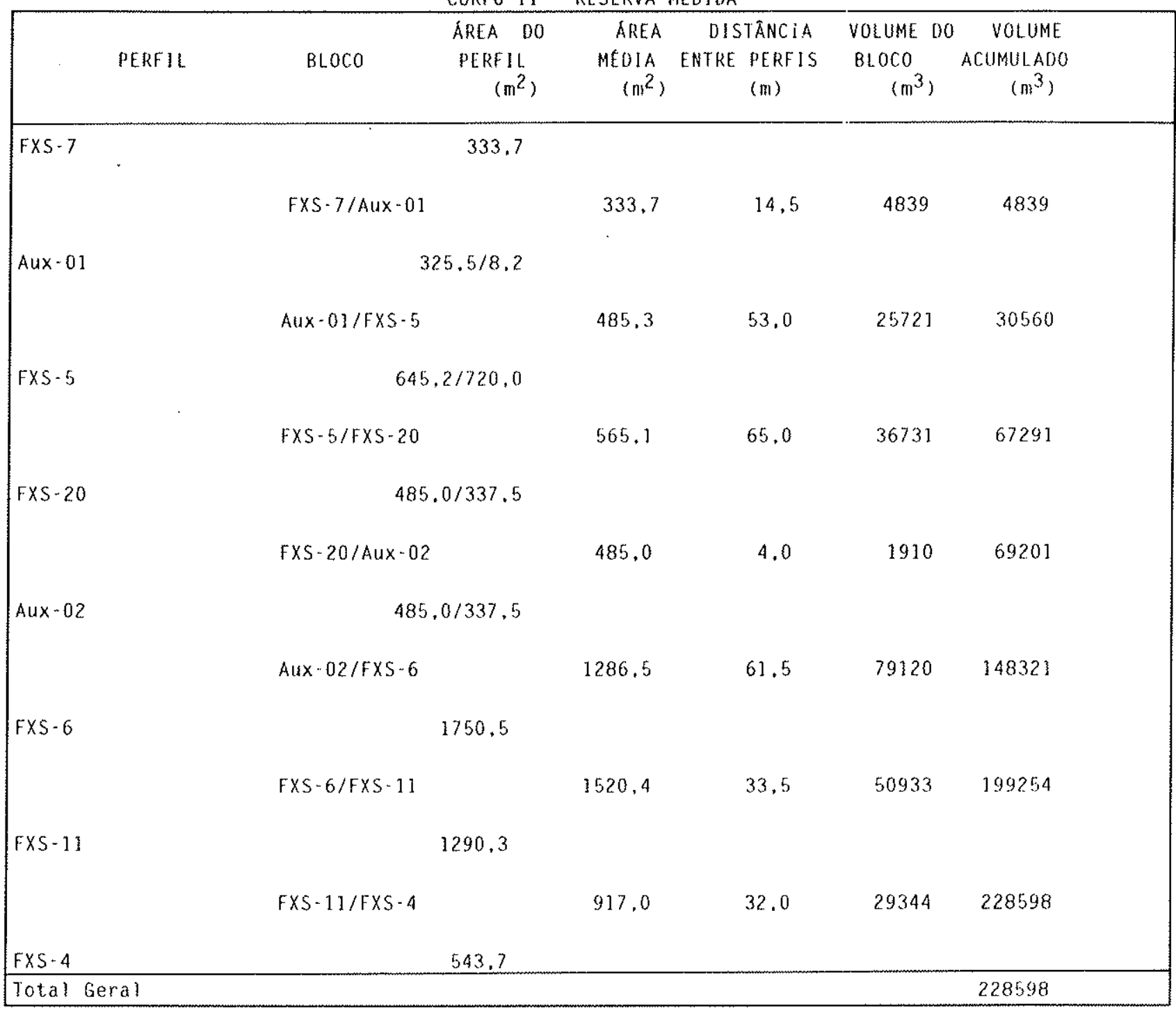


QUADRO VI

DEPOSITO XUPE

CORPO 11 - RESERVA INOICADA

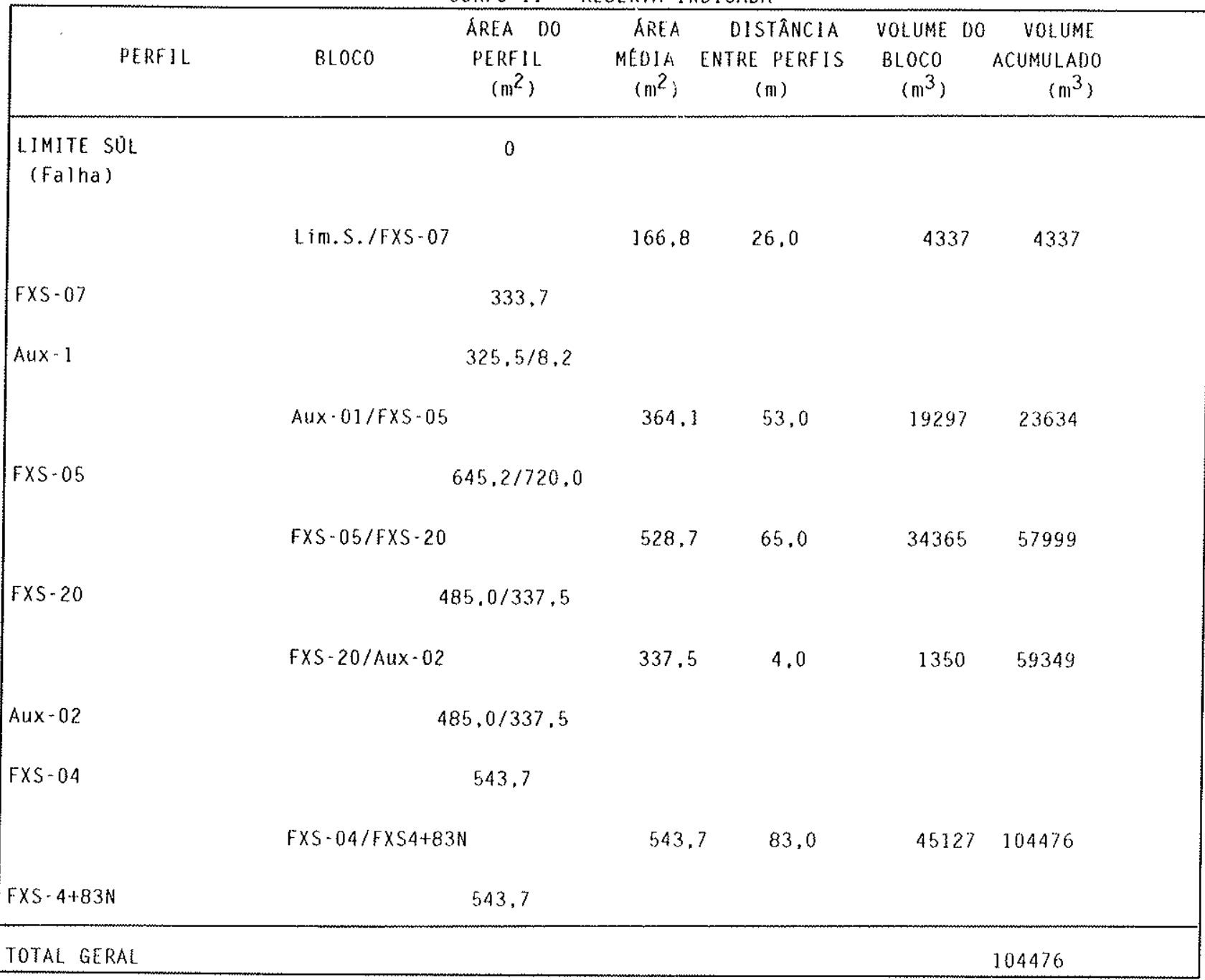

QUADRO VII

QUADRO GERAL DE RESERVA

RESERVA MEOIOA

\begin{tabular}{|c|c|c|c|}
\hline CORPO & $\begin{array}{l}\text { VOLUME } \\
\left(m^{3}\right)\end{array}$ & $\begin{array}{l}\text { Sn contido }(\mathrm{Kg}) \\
\text { Teor } \\
1695,0 \mathrm{~g} / \mathrm{m}^{3}\end{array}$ & $\begin{array}{c}\left.\mathrm{Ta}_{2} 0_{5} \text { contido ( } \mathrm{kg}\right) \\
\text { Teor } \\
53 \mathrm{~g} / \mathrm{m}^{3}\end{array}$ \\
\hline I & $8096 \mathrm{~J}$ & 137228 & 4291 \\
\hline Il & 228598 & 387473 & 12116 \\
\hline Total & 309559 & 524701 & 16407 \\
\hline
\end{tabular}


QUADRO VIII

RESERVA INDICADA

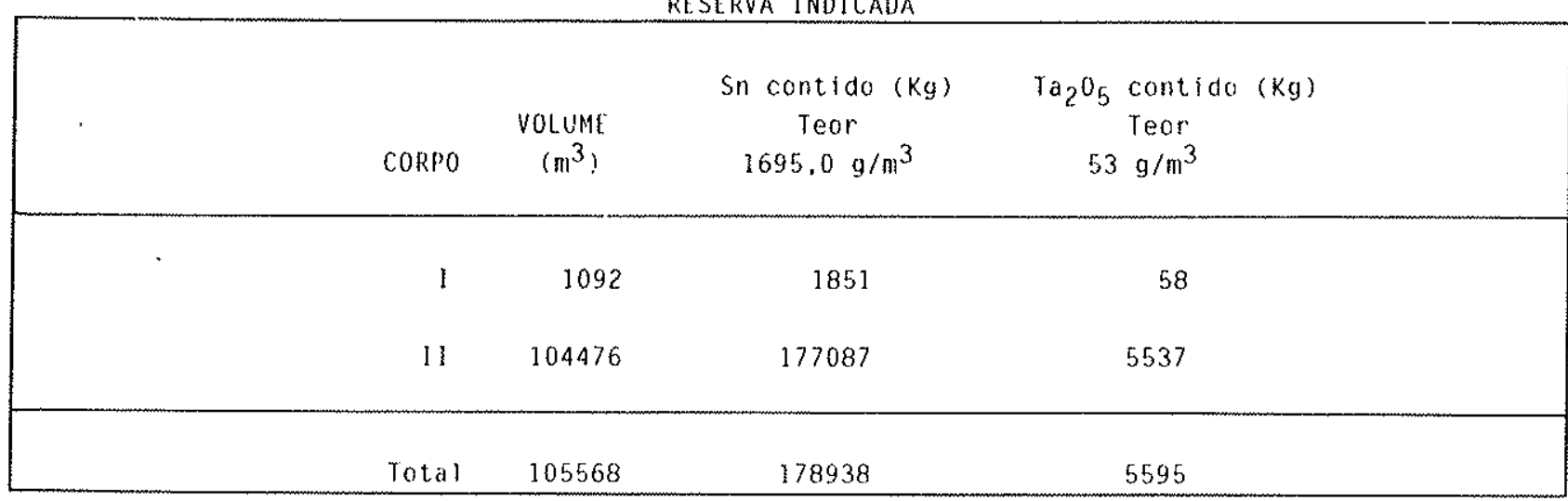

QUADRO IX

QUADRO RESUMO DA RESERVA TOTAL POR CORPOS DE MINERIO

\begin{tabular}{|c|c|c|c|}
\hline CORPO & $\begin{array}{l}\text { VOLUNE } \\
\left(\mathrm{m}^{3}\right)\end{array}$ & $\begin{array}{c}\text { Sn contido }(\mathrm{kg}) \\
\text { Teor } \\
1695.0 \mathrm{~g} / \mathrm{m}^{3}\end{array}$ & $\begin{array}{c}\mathrm{Ta}_{2} \mathrm{O}_{5} \text { contido }(\mathrm{Kg}) \\
\text { Teor } \\
53 \mathrm{~g} / \mathrm{m}^{3}\end{array}$ \\
\hline l & 82053 & 139080 & 4349 \\
\hline II & 333074 & 564560 & 17653 \\
\hline Total & 415127 & 703640 & 22002 \\
\hline
\end{tabular}

Pelo exposto verifica-se que, da análise dos documentos fundamentais disponiveis da pesquisa do pegmatito Xupé dois corpos de minério puderam ser individualizados, ou seja, Corpo I e Corpo II.

As reservas desses corpos, avaliadas pelo método dos perfis padrão, estão resumidas no Quadro IX. Elas constituem um depósito de estanho e $\mathrm{Ta}_{2} \mathrm{O}_{5}$ da ordem de $415.000 \mathrm{~m}^{3}$ de minério, contendo 703,64 t de estanho metálico e 22,00 t de pentóxido de tântalo. 


\section{CÁpítuLO 10}

\section{CONCLUSÕES E CONSIDERAÇÕES FINAIS}

Este trabalho apresenta um estudo comparativo entre os resultados de um programa de amostragem em furos de sondagem e galerias para pesquisa de cassiterita no Pegmatito Xupé.

Em face dos conceitos e técnicas perseguidos neste trabalho de pesquisa mineral sobreleva-se a importância do processo de amostragem no cotidiano de geólogos, engenheiros e estudiosos das ciências da Terra, durante o desenvolvimento de qualquer pesquisa mineral.

O essencial na amostragem é a avaliação do teor médio dos bens minerais, que, de acordo com o Teorema do Limite Central, tende à média da população numa distribuição de freqüência do tipo normal, qualquer que seja a distribuição original dos dados. Com a prática da amostragem reduzem-se os custos, quando é impossível examinar a massa total de material em estudo. Independentemente dos objetivos com que põe em prática esse processo, ele é o início de tudo, e, se não for de qualidade, menos ainda serão seus resultados. O procedimento incorreto de amostragem pode conduzir a resultados distorcidos que oneram, descaracterizam ou inviabilizam a pesquisa e o aproveitamento do bem mineral.

Neste trabalho pôde-se mostrar ainda o comportamento dos teores de estanho nos intervalos amostrados nas galerias e testemunhos de sondagem, através da análise estatística de dados que objetivam caracterizar e descrever com precisão as populações amostradas por meio do estudo das distribuições de freqüências e suas características numéricas. Assim, as populações amostradas nos furos de sondagem e nas escavações subterrâneas mostraram que a distribuição de frequêencia para os testemunhos é altamente assimétrica e (assimetria positiva), não normal tendendo a uma distribuição lognormal - onde aproximadamente $80 \%$ dos dados ficam numa única classe $(0-350 \mathrm{ppm})$. Em contrapartida a distribuição de freqüência dos dados de estanho nos avanços continua sendo assimétrica (assimetria positiva), porém melhor distribuída, caracterizando dispersão menor que aquela verificada nos furos.

Pela descrição numérica da distribuição de freqüência, verifica-se que, enquanto o teor médio dos furos é igual a $341 \mathrm{ppm}$, os avanços apresentam $792 \mathrm{ppm}$ de estanho. Essa diferença é atribuída aos processos de amostragem, pois os volumes amostrados nos furos são muito menores que o volume das galerias, fato este que se justifica pela redução da variância. A relação volume/variância indica que, à medida que o volume da amostra cresce, a variância da distribuição de valores decresce. Para depósitos de alto coeficiente de variação, os problemas de avaliação são dificeis de resolver. Além disso os fatores que afetam a confiabilidade (limite de confiança) estão associados à estimativa da média. 
O Pegmatito Xupé foi definido espacialmente por trabalhos de pesquisa geológica executados na década de 1980 pela equipe de geólogos das Empresas Brumadinho. Estes trabalhos de superficie e subsuperficie constituem-se de mapeamento geológico à escala 1:500 e $1: 200$, respectivamente, 15 furos de sondagem rotativa a diamante e $317 \mathrm{~m}$ de galerias. $O$ termo "pegmatito" utilizado para denominação Pegmatito Xupé é uma generalização de âmbito local para rochas do tipo pegmatito granítico, na forma de diques e bolsões. Sua configuração lenticular subvertical é controlada estruturalmente por uma zona de cisalhamento regional com direção N-NE. Esse corpo aloja-se preferencialmente em rochas xistosas da Formação Ticunzal e gnaisses-graníticos do embasamento goiano. $\mathrm{Na}$ falta de estudos petroquímicos detalhados, o Pegmatito Xupé a nosso ver seria melhor classificado na familia LCT dos pegmatitos de elementos raros (Cerny, 1991) em razão das rochas encaixantes serem gnaisses e xistos, e pelo controle estrutural de uma zona de cisalhamento.

A revisão dos métodos clássicos para avaliação de reservas foi estudada segundo Popoff (1966), o qual se baseia fundamentalmente nos princípios de interpretação de variáveis entre dois pontos contíguos de amostragem, determinadores da construção de blocos geométricos aos quais se atribuem teores ou teores médios para cálculo de reserva. Os métodos clássicos ou convencionais citados são: blocos análogos, blocos de lavra, analíticos e dos perfis.

Para quantificação das reservas foram usados os critérios básicos indispensáveis para cálculo, com individualização de dois segmentos ou corpos de minério: corpo I e corpo II. Os teores utilizados foram os obtidos no cálculo estatístico dos teores de $\mathrm{Sn}$ e $\mathrm{Ta}_{2} \mathrm{O}_{5}$ para as amostras da galeria. $\mathrm{O}$ volume total de minério, $415000 \mathrm{~m}^{3}$, não inclui o material estéril das faixas quartzosas internas ao corpo II. Apesar dos teores $1695 \mathrm{~g}$ de $\mathrm{Sn} / \mathrm{m}^{3}$ e $53 \mathrm{~g}$ de $\mathrm{Ta}_{2} \mathrm{O}_{5} / \mathrm{m}^{3}$ serem o valor mais correto em função de amostras das galerias, a extensão desses valores médios à totalidade dos corpos deve ser apreciada com cautela, pois, na maior parte dos depósitos pegmatíticos, não se observa regularidade tão marcante. $O$ aproveitamento do depósito, para valores de venda de estanho entre US\$ $5.50 / 6.00$ por quilo, para os próximos cinco anos, apresenta-se no limite da economicidade ao se admitir custo de tratamento de US\$2.00/t de minério, custo de lavra US $\$ 4.00 / \mathrm{t}$ de minério ou estéril, custo de metalurgia a US $\$ 1.00 / \mathrm{Kg}$ de Sn metal e administração igual a US\$1.00/t de minério, a menos que a mineração seja do tipo familiar. 


\section{REFERÊNCIAS BIBLIOGRÁFICAS}

ALMEIDA, F.F.M. de. 1967. Origem e evolução da Plataforma Brasileira. Rio de Janeiro, DNPM/IDGM. 36p. (Boletim 241).

ALMEIDA, F.F.M. de; HASUI, Y.; NEVES, B.B.; FUCK, R.A. 1977. Províncias Estruturais Brasileiras. In: SIMP. GEOL. NORDESTE, 8, Campina Grande, 1977. Atas ...Campina Grande, SBG. p.363-391.

ALMEIDA FILHO, R. 1983. Sensoriamento remoto orbital aplicado à prospecção mineral nas províncias estaníferas de Goiás e Rondônia: uma contribuição metodológica. São Paulo. $171 \mathrm{p}$. (Tese de Doutoramento apresentada no Instituto de Geociências-USP).

ANNELS, A.E. 1991. Mineral Deposit Evaluation. A practical Approach. London, Chapman \& Hall. 436p. ARAUJO, V.A. \& ALVES, A.C. 1979. Projeto Canabrava-Porto Real: relatório final. Goiânia, Conv. DNPM/CPRM. v. 1, 191 p.

BARBOSA, O.B. et alii. 1969. Projeto Brasília-Goiás: geologia e inventário dos recursos minerais. Petrópolis, DNPM/PROSPEC. 225p.

BARCELLOS, M.S. 1985. Relatório complementar dos trabalhos de pesquisa. Goiânia. Iguatu Mineração Ltda. Processo DNPM no 807957/76. 2 vols.

BARNES, M.P. 1980. Computer-Assisted Mineral Appraisal and Feasibility. New York, Soc. Min. Eng. 167p.

BAXTER, C.H. \& PARKS,R.D. 1939. Mine Examination and Valuation. Houghton, Michigan College of Mines and Technology. 2. ed. $331 \mathrm{p}$.

BETTENCOURT, J.S.; DAMASCENO, E.C.; FONTANELLI, W.S.; FRANCO, J.R.M.; PEREIRA, N.M. 1981. Brazilian tin deposits and potencial. In: WORLD CONF. ON TIN, 5, Kuala Lumpur, 1981. Paper...Kuala Lumpur, Ministry of Primary Industries \& International Tin Council. $69 \mathrm{p}$.

BETTENCOURT, J.S., 1985. Trabalhos de pesquisa e avaliação de reservas de estanho e $\mathrm{Ta}_{2} \mathrm{O}_{5}$ do Distrito de Monte Alegre de Goiás, GO. São Paulo, $31 \mathrm{p}$. Arquivos das Empresas Brumadinho.

BOTELHO, N.F. 1984. O granito Pedra Branca (Goiás) e as mineralizacões de estanho associadas. Brasília. 258p (Dissertação de Mestrado-UNB).

BOTELHO, N.F.; MARINI, O.J.; PAGOTTO, G.A.; ROSSI, G.; ABE, C.K.; URA, C.; POSTAL, F. 1986. Província estanifera do leste de Goiás (Subprovíncia do Rio Paranã). Roteiro das Excursões Técnico-Científicas: Excursão no 5. In: CONGR. BRAS. GEOL., 36, Goiânia, 1986, Boletim...Goiânia, SBG. p.133-147. 
BOTELHO, N.F. \& ROSSI, G. 1988. Depósito de estanho de Pedra Branca, Nova Roma, Goiás. In: Schobbenhaus, C. \& Silva Coelho, C.E.S. (Coords). Principais depósitos minerais do Brasil. Brasília, DNPM/CVRD. v. III, p. 267-285.

BRAUN, O.P.G. 1968. Contribuição à estratigrafia do grupo Bambuí. In: CONGR. BRAS. GEOL., 22, Belo Horizonte, 1968, Anais...Belo Horizonte, SBG. p. 155-166.

CERNY, P. 1982. Anatomy and classification of granitic pegmatites. In: CERNY, P. (ed.) Short Course in Granitic Pegmatites in Science and Industry. Winnipeg, Mineral. Assoc. Can. v. 8, p.405-462.

CERNY, P. 1982. Exploration for rare-element granitic pegmatites. In: CERNY, P. (ed.) Short Course in Granitic Pegmatites in Science and Industry. Winnipeg, Mineral. Assoc. Can. v. 8, p.463-493.

CERNY, P. \& MEINTZER, R.E. 1988. Fertile granites in the Archean and Proterozoic fienlds of rare-element pegmatites: crustal enviromment, geochemistry and petrogenetic relationships. In: TAILOR, R.P. \& STRONG, D.F. (eds) Recent advances in the geology of granite-related mineral deposits. CIM Special Volume 39, p. 170-207.

CERNY, P. 1989. Exploration strategy and methods for pegmatites deposits of tantalium. In: Molhher, P.; Cerny, P.; Saupé, F. (eds) Lanthanides, tantalum and niobium. Berlim, Springer-Verlag. p.274-302.

CERNY, P. 1991. Rare-element granitic pegmatites. Part I: anatomy and internal evolution of pegmatite deposits. Geosc. Can., 18(2):49-67.

CERNY, P. 1991. Rare-element granitic pegmatites. Part II: regional to global environments and petrogenesis. Geosc. Can. 18(2):68-81.

CHAND, F. 1981. A manual of Geochemical Exploration Methods. Kuala Lumpur, Geological Survey of Malaysia. Special paper 3.

COCHRAN, W.G. 1963. Técnicas de amostragem. Rio de Janeiro, Fundo de Cultura. 555p.

DAMASCENO, E.C. 1988. Geologia do estanho. In: Schobbenhaus, C. \& Silva Coelho, C.E.S. (Coords). Principais depósitos minerais do Brasil. Brasília, DNPM/CVRD. v. III, p.183-199.

DAVID, M. 1988. Handbook of applied advanced geostatistical ore reserve estimation. New York, Elsevier Science. $216 \mathrm{p}$.

FONTANELLI, W.S. 1982. Relatório final dos trabalhos de pesquisa. Sào Paulo. Iguatu Mineração Ltda. Processo DNPM no807.957/76, 25p.

FUCK, R.A. \& MARINI, O.J. 1978. Granitos estaniferos no centro-leste de Goiás. In: CONGR. BRAS. GEOL., 30, Recife, 1978, Resumos...Recife, SBG. p.311-312. 
FUCK, R.A. \& MARINI, O.J. 1981. O Grupo Araxá e unidades homotaxiais. In: SiMP. SOBRE O CRÁTON S. FRANCISCO E SUAS FAIXAS MARGINAIS, Salvador, 1979, Anais ... Salvador, SBG. p.118-130.

GARCIA GUERRA, P.A. 1988 Geoestatística Operacional. Brasília, DNPM. 145p.

GOES, M.A.C.; POSSA, M.V.; LUZ, A.B. 1991. Amostragem de minérios. Rio de Janeiro, CETEM (série tecnologia mineral, 49). 48p.

GY, P. 1953. Erreur commise dans le prelevement d'un enchantillon sur un list de minerai. In: CONGRES DES LAVERIES DES MINES METALLIQUES. Paris, september, 1953.

GY, P. 1968. Theory and practice of sampling broken ores. Montreal, Can. Inst. Min. Metall. Spec. v. 9, p.5-10.

HANDLEY, G.A.; LEWIS, R.W.; WILSON, I. 1987. The collection and management of ore reserve estimation data. In: RESOURCES AND RESERVES SYMPOSIUM, Sydney, 1987. Proceedings...Sydney, THE AUSTRALASIAN INSTITUTE OF MINING AND METALLURGY.p.27-30.

INGAMELLS, C.O. \& PITARD, F.F. 1986. Applied geochemical analysis. New York, John Wiley $\&$ Sons. $733 p$.

JAHNS, R.H. 1953. The genesis of Pegmatites ii. quantitative analysis of lithium-bearing pegmatite, Moracounty, New Mexico. Am. Mineral., 38:1078-1112.

JENSEN, M.L. \& BATEMAN,A.M. 1979. Economic Mineral Deposits. New York, John Wiley \& Sons. 593 p.

JOHNSON, W.M. \& MAXWELL, J.A. 1981. Rock and Mineral Analysis. New York, John Wiley \& Sons. 489 p.

JONES, M.P. 1987. Applied Mineralogy. A quantitative Approach. London, Graham \& Trotman. 259p.

KOCH Jr, G.S. \& LINK, R.F. 1971. Statistical analysis of geological data. New York, Dover Publ. v. 1, 375p.

KREITER, V.M. 1968. Geological prospecting and exploration. Moscow, MIR PUblishers. $383 \mathrm{p}$.

KRETZ, R. 1968. Study of pegmatite bodies and enclosing rocks. Yellowknife-Bealieu region, District of Mackenzie. Can. Geol. Surv. Bull., 158, 108p.

MARINI, O.J. et alii. 1978. Nova Unidade litoestratigráfica do Précambriano do Estado de Goiás. In: CONGR. BRAS. GEOL., 30, Recife, 1978, Resumos...Recife, SBG. p.126127. 
MARINI, O.J.; FUCK, R.A.; DARDENNE, M.A.; DANNI, J.C.M. 1984. Província Tocantins: Setores Central e Sudeste. In: Almeida, F.F.M. \& Hasui, Y. (Coords.) O Précambriano do Brasil. São Paulo, Edgard Blücher p.205-264.

MARINI, O. J. \& BOTELHO, N.F. 1986. A província de granitos estaníferos de Goiás. Rev. Bras. Geoc., 16(i):119-131. MATHERON, G. 1963. Principles of geostatístics. Econ. Geol., 58:1246-1266.

MCKINSTRY, H.E. 1948. Mining Geology. New Jersey, Prentice Hall. 680p.

MIESCH, A.T. 1967. Theory of error in geochemical data. Washington, USGS. (USGS Professional Paper, 574-A).17p.

MOLlHER, P.; CERNY, P.; SAUPÉ, F. 1989. Lanthanides, tantalum and Niobium: mineralogy, geochemistry and characteristics of primary ore deposits. Prospecting, processing and applications. New York, Springer-Verlag. 380p.

OTTLEY, D.J. 1966. Pierre Gy's sampling slide rule. Can.Min.J. (7):58-62.

PADILHA, J.L. \& LAGUNA, A.M.G. 1981. Geologia dos granitos da Pedra Branca, Mocambo, Mangabeira e Serra do Mendes-Goiás. In: SIMP. GEOL. CENTRO-OESTE, 10, Goiânia, 1981. Atas...Goiânia, SBG. p.622-643.

PAGE, L.R.; ADAMS, J.W.; ERICKSON, M.P.; HALL, W.E.; HANLEY, J.B.; JORALEMOON, P.; NORTON, J.J.; PRAY, L.C.; STEVEN, T.A.; STOLL.; W.C.; STOPPER, R.F. 1953. Pegmatite investigation 1942-45 Black Hills, South Dakota. U.S.G.S. Rec., 1986/10, p.53-54.

PAGOTTO, G.; MONTANHEIRO, T.J.; ROSSI, G.; BETTENCOURT,J.S. 1990. Pegmatitos à metais raros $(\mathrm{Sn}, \mathrm{Nb}, \mathrm{Ta}, \mathrm{Be}, \mathrm{Li})$ da região de Monte Alegre de Goiás, GO. In: CONGR. BRAS. GEOL., 36, Natal, 1990. Resumos...Natal, SBG. p. 153

PARKS, R.D. 1949. Sampling, Examination and Valuation of Mineral Property. 3. ed. Cambridge, Addison-Wesley Press.

PAULO ABIB ENGENHARIA S/A. 1983. Estudos de caracterização tecnológica em amostras de cassiterita primária - Xupé (MOS). São Paulo, Salomão Mineração Ltda. $28 \mathrm{p}$.

PEELE, R. 1941. Mining Engineers' Handbook. New York. John Wiley \& Sons. v. 2, 2442p.

PETERS, W.C. 1987. Exploration and mining geology. 2. ed. New York, John Wiley \& Sons. $685 \mathrm{p}$.

PETTINATI, F. 1983. Modelamento digital e representação gráfica de superficies. São Paulo. 177p. (Dissertação de Mestrado apresentada à Escola Politécnica da USP). 
PITARD, F.F. 1992. Pierre Gy's sampling theory and sampling practice. New York, CRC Press. 214p.

POPOFF, C.C. 1966. Computing reserves of mineral deposits: principles and conventional methods. Washington, Bureau of Mines. 113p. (I.C. 8283).

RADAMBRASIL, 1981. Folha SD.22, Goiás. Rio de Janeiro, MME/Projeto Radambrasil. $636 p$.

RADAMBRASIL, 1981. Folha SD.23, Brasilia. Rio de Janeiro, MME/Projeto Radambrasil. $655 \mathrm{p}$.

REIS NETO, J.M. 1983. Evolução Geotectônica da Bacia do Alto Tocantins, GO. São Paulo, 98p. (Dissertação de Mestrado apresentada no Instituto de Geociências-USP)

SCHOBBENHAUS Fo , C. \& LEAL BRUNI, M.A. 1976. Carta Geológica do Brasil ao milionésimo, Folha Brasilia, SD.23. Brasilia, MME/DNPM, DEM. 87p.

SCHOBbenhauS, C. \& SILVA COELHO, C.E. 1988. Principais Depósitos Minerais do Brasil. Brasília, DNPM/CVRD. v. III, 670p.

TAGGART, A.F. 1945. Handbook of mineral dressing. New York. John Wiley \& Sons. $1905 \mathrm{p}$.

VARLAMOFF, N. 1972. Central and West African rare metal granitic pegmatites, related aplites, quartz veins and mineral deposits. Miner. Deposita, I, p.202-216.

WAENY, J.C. de C. 1978. Procedimentos e padrões internos para sistema dinâmico de confiabilidade metrológica. São Paulo, IPT. (Técnicas e Métodos, 1). 16p.

WAENY, J.C. de C. 1979. Recomendações para nomenclatura de confiabilidade metrológica. São Paulo, IPT. (Publicação Interna, 2). 23p.

YAMAMOTO, J.K. 1991 - Comparação de métodos computacionais para avaliação de reserva: um estudo de caso na Jazida de Cobre de Chapada, GO. São Paulo. 175p. (Tese de Doutoramento apresentada ao Instituto de Geociências USP).

YAMAMOTO, J.K.\& BETTENCOURT, J.S. 1992. Avaliação de jazidas. São Paulo, Instituto de Geociências-USP. 113p.

YAMAMOTO, J.K. 1992. Geoestatística Aplicada. São Paulo, Instituto de Geociências-USP. $166 \mathrm{p}$.

YAMAMOTO, J.K. 1993. Amostragem. São Paulo, Instituto de Geociências-USP. 33p. 


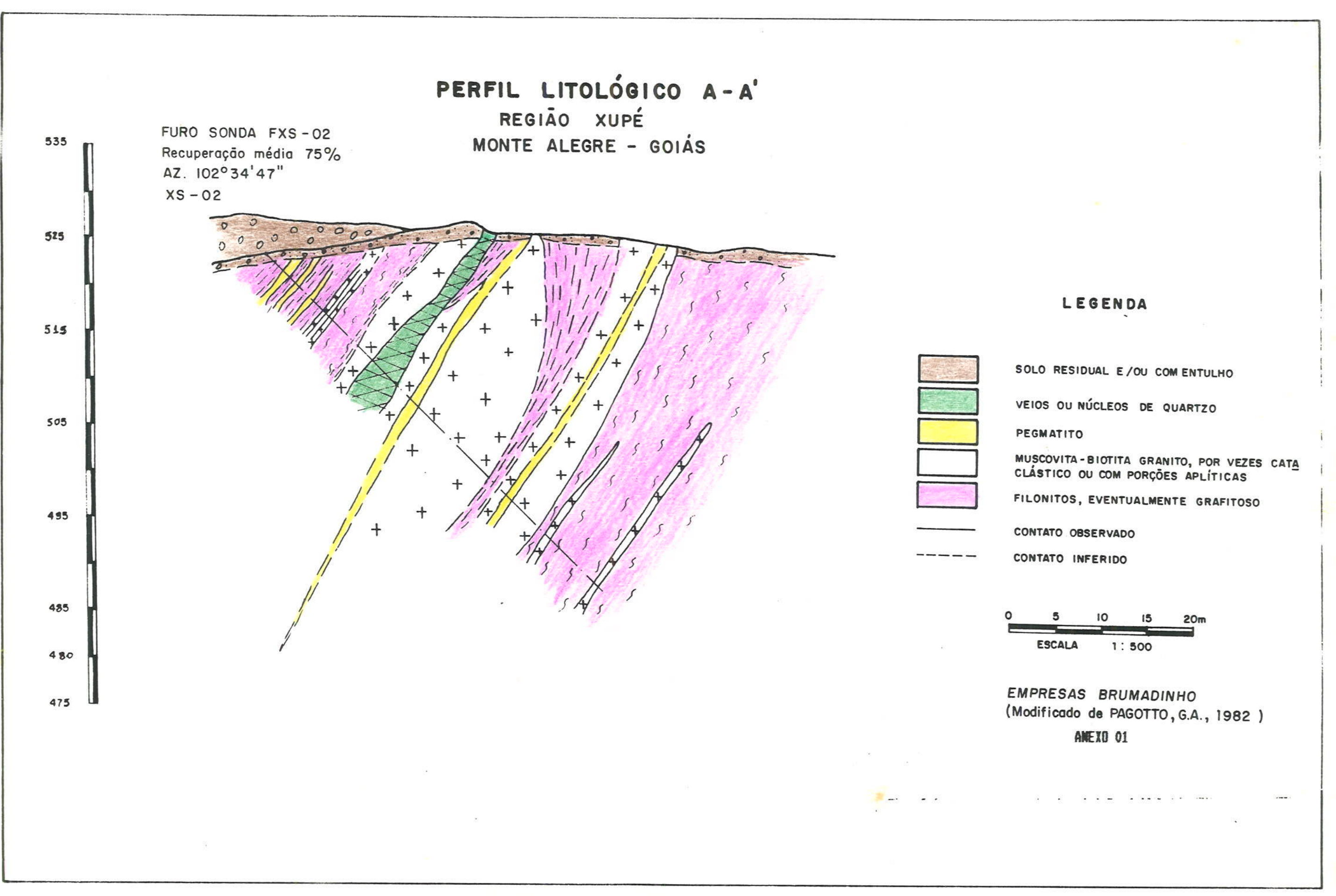


FURO SONDA FXS - 01 Recuperaçāo média $85 \%$ AZ. $103^{\circ} 05^{\prime} 49^{\prime \prime}$

535

525

$\mathrm{XS}-01$
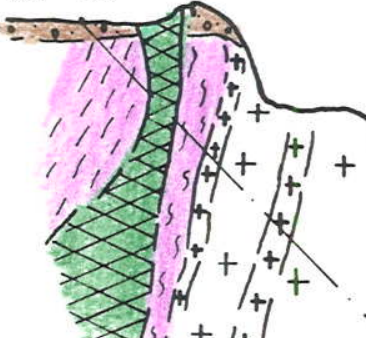

$+$

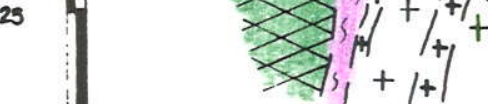

PERFIL LITOLÓGICO B - $B^{\prime}$

REGIĀO XUPÉ

MONTE ALEGRE - GOIÁS
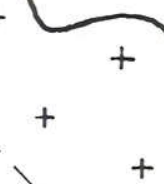

$+$

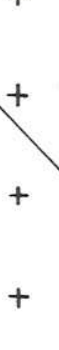

(2)
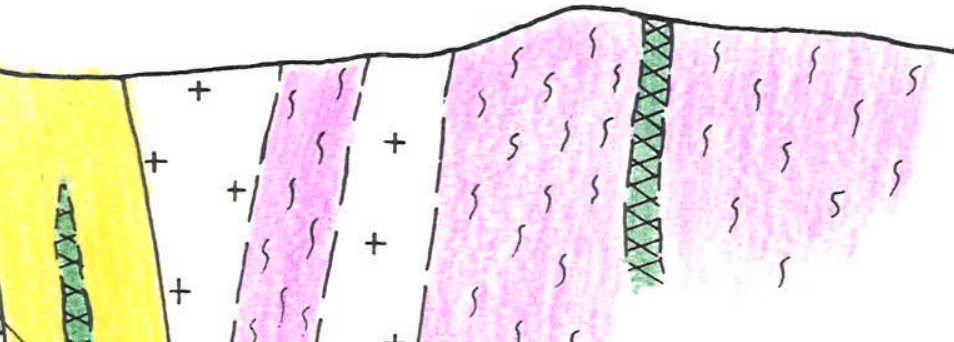

\section{LEGENDA}

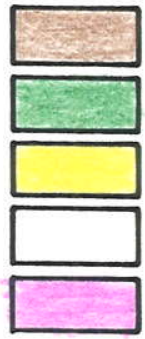

SOLO RESIDUAL E/OU COM ENTULHO

VEIOS OU NÚCLEOS DE QUARTZO

\section{PEGMATITO}

MUSCOVITA-BIOTITA GRANITO, POR VEZES CATA CLÁSTICO OU COM PORÇÕES APLITITCAS

FILONITOS, EVENTUALMENTE GRAFITOSO

CONTATO OBSERVADO

CONTATO INFERIDO

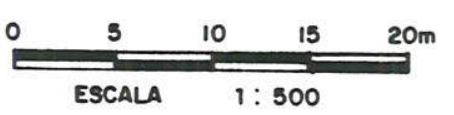

EMPRESAS BRUMADINHO

(Modificado de PAGOTTO, G.A., 1982 )

AIEXX 02 
PERFIL LITOLÓGICO C-C'

REGIĀO XUPÉ

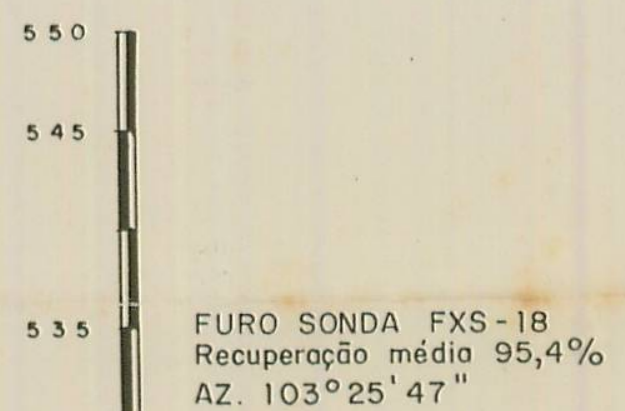

FURO SONDA FXS-03

MONTE ALEGRE - GOIÁS

AZ $103^{\circ} 2547^{11}$
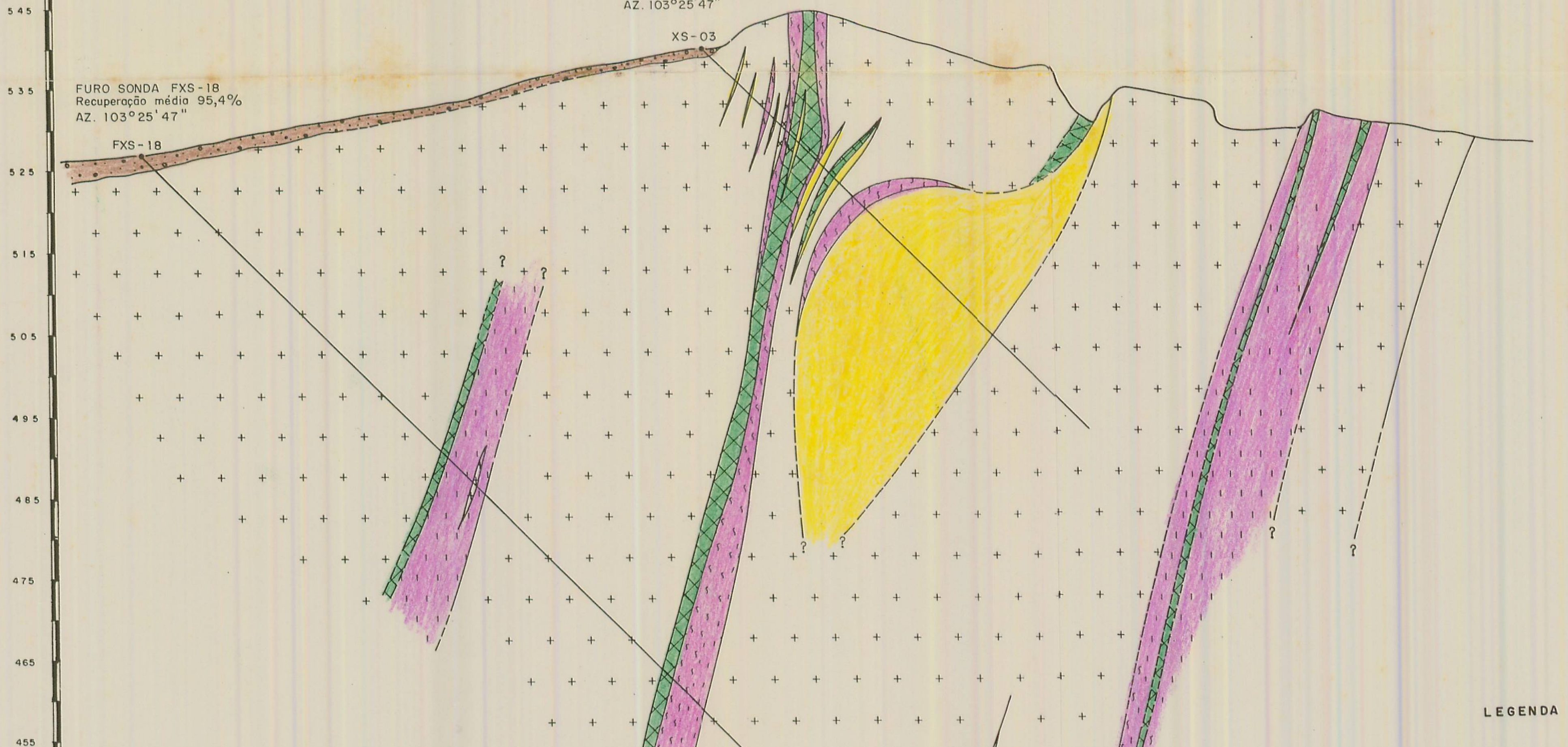

455

465

445

435

425

415

405

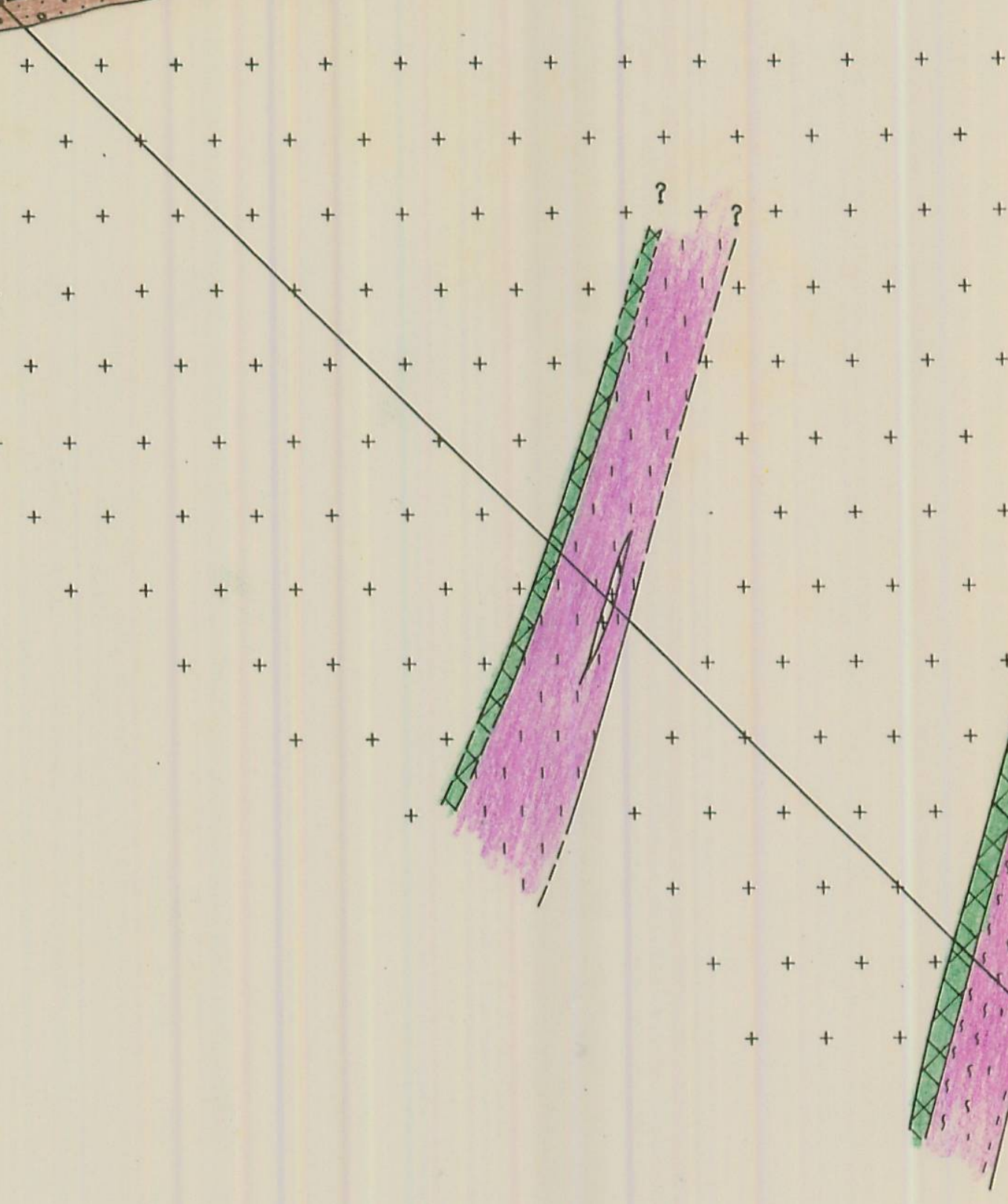

s- 03

SOLO RESIDUAL E/OU COM ENTULHO

VEIOS OU NÚCLEOS DE QUARTZO

PEGMATITO

MUSCOVITA-BIOTITA GRANITO, POR VEZES CATA

RES APLITICAS

FILONITOS, EVENTUALMENTE GRAFITOSO

CONTATO OBSERVADO

CONTATO INFERIDO

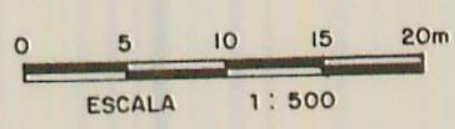

EMPRESAS BRUMADINHO (Modificado de PAGOTTO, G.A., 1982)

ANEXO 03 


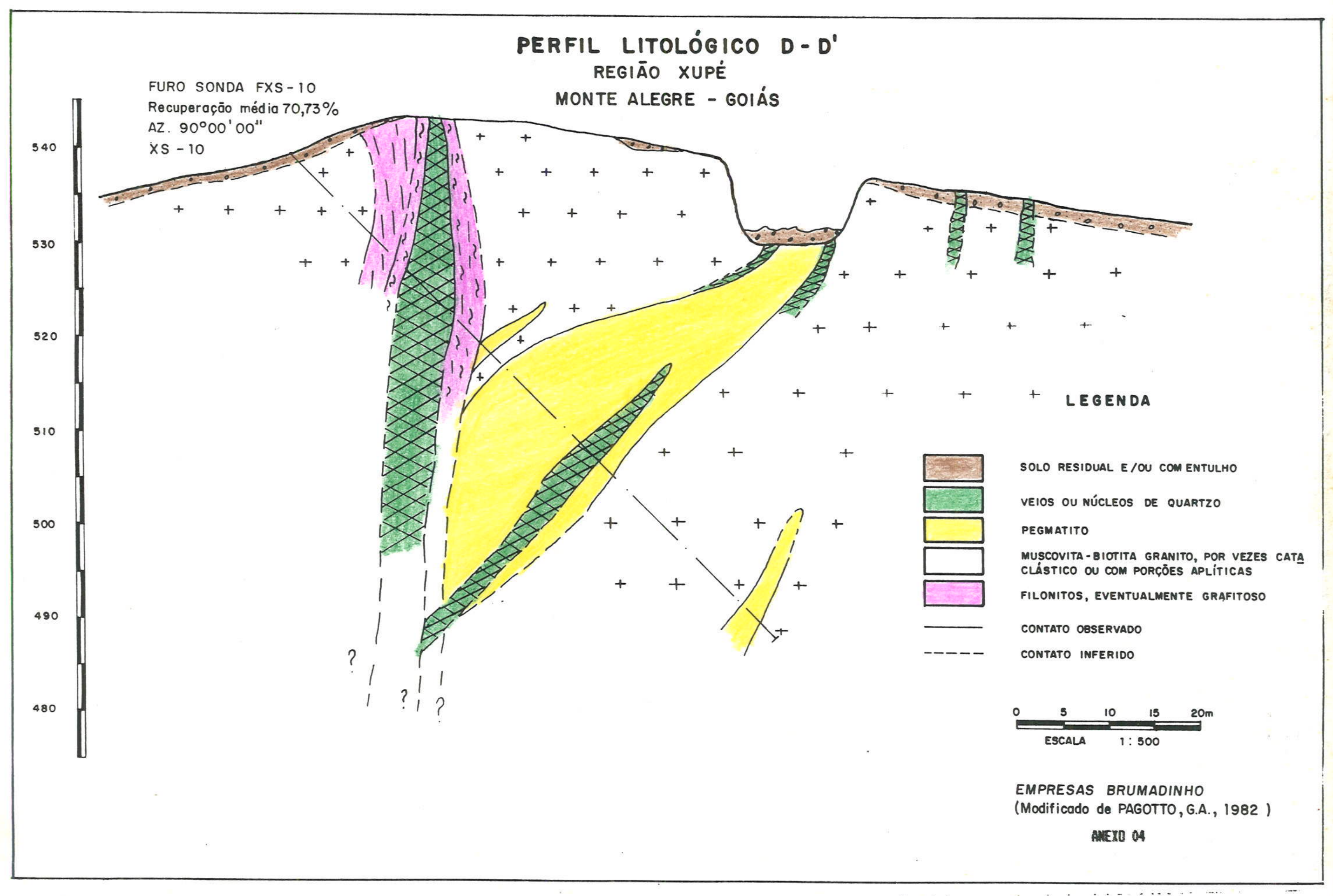




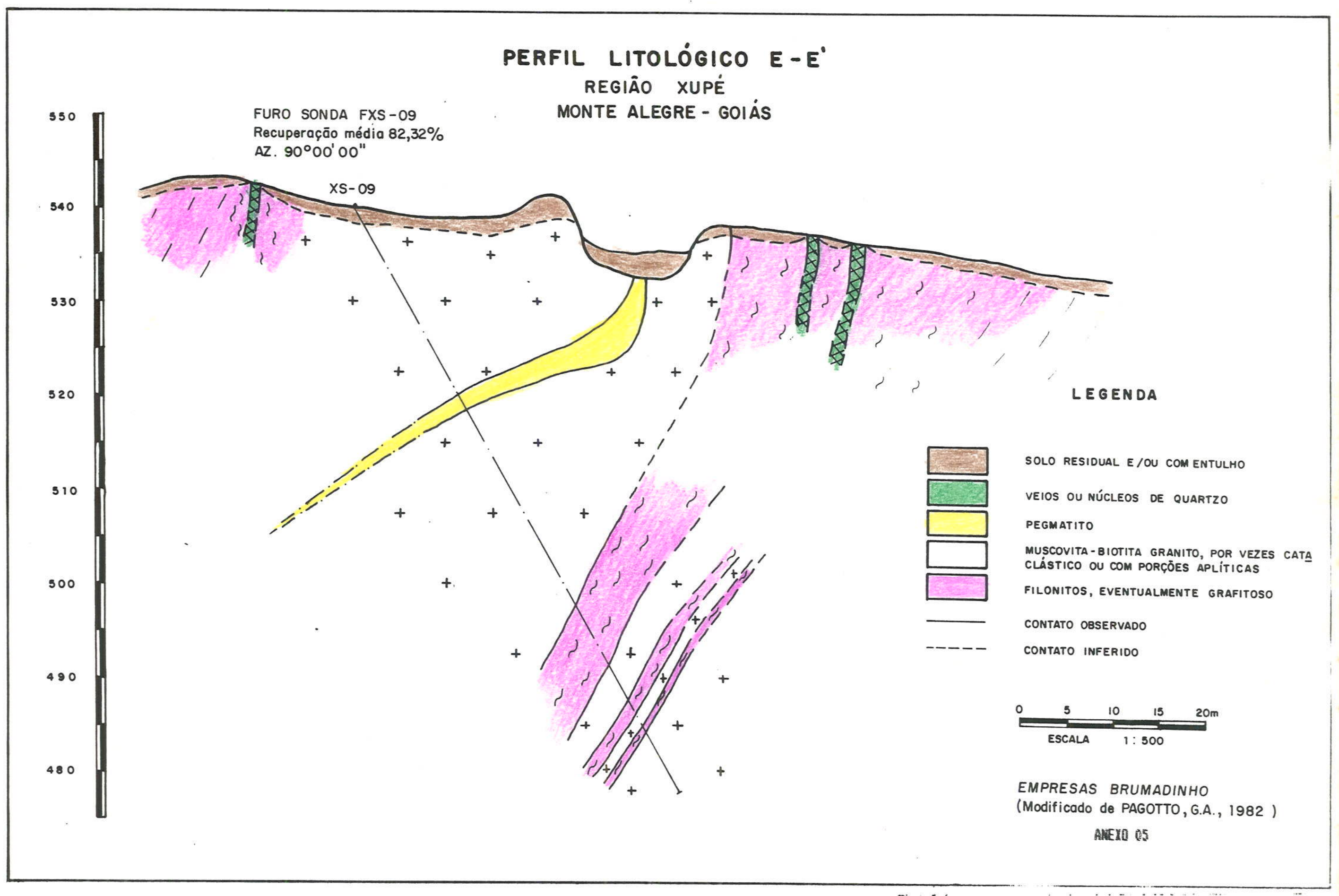




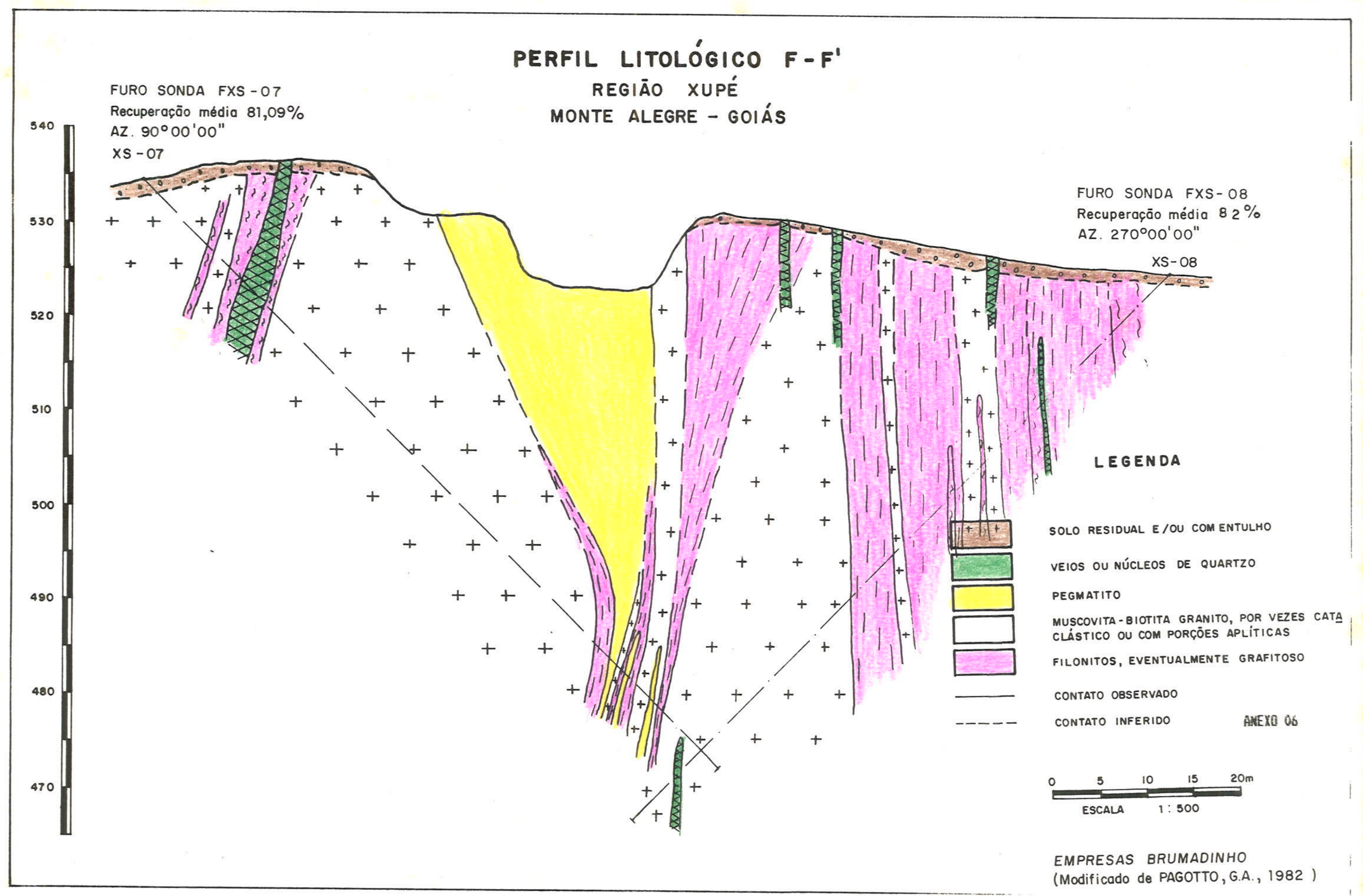




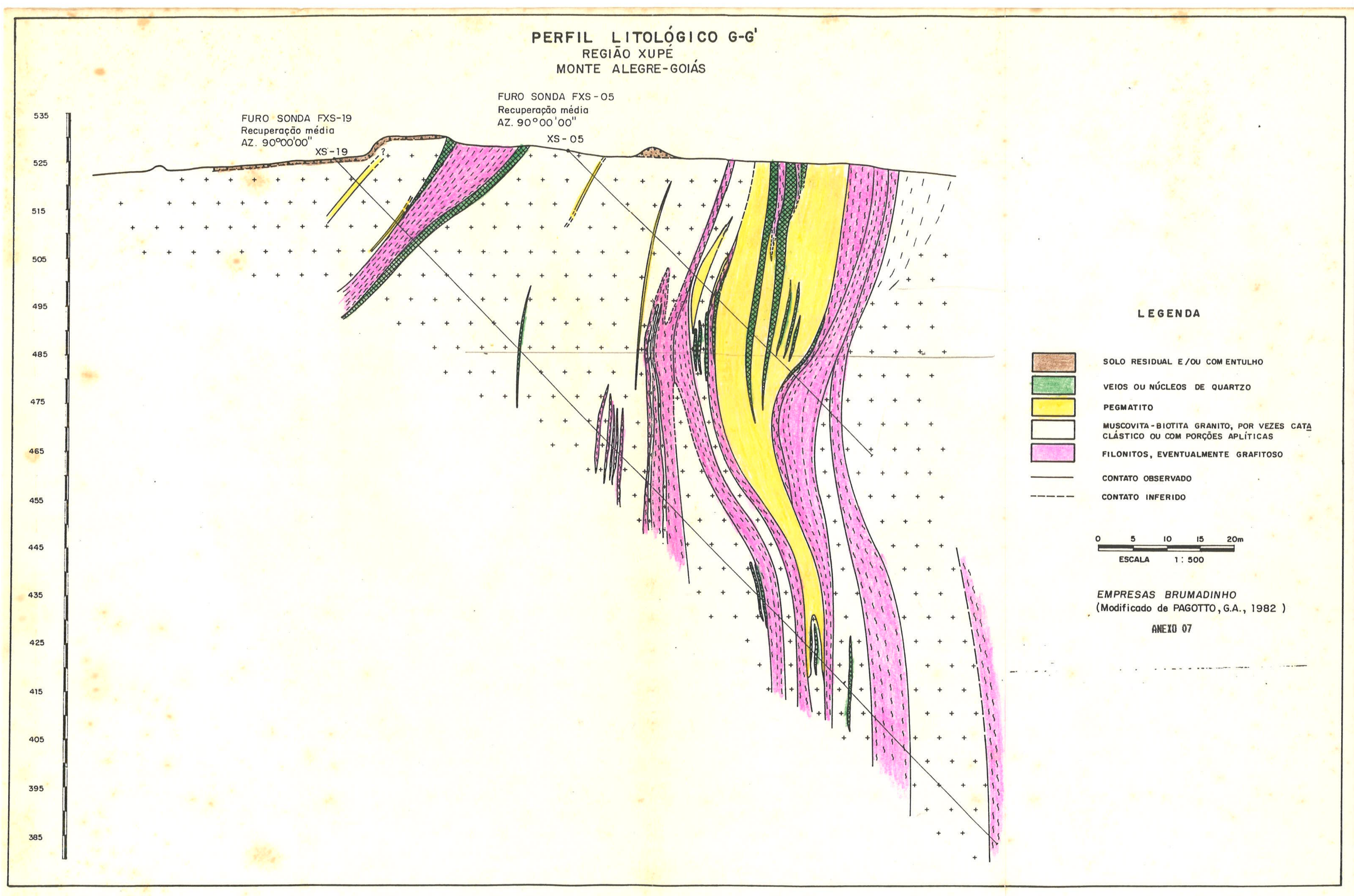




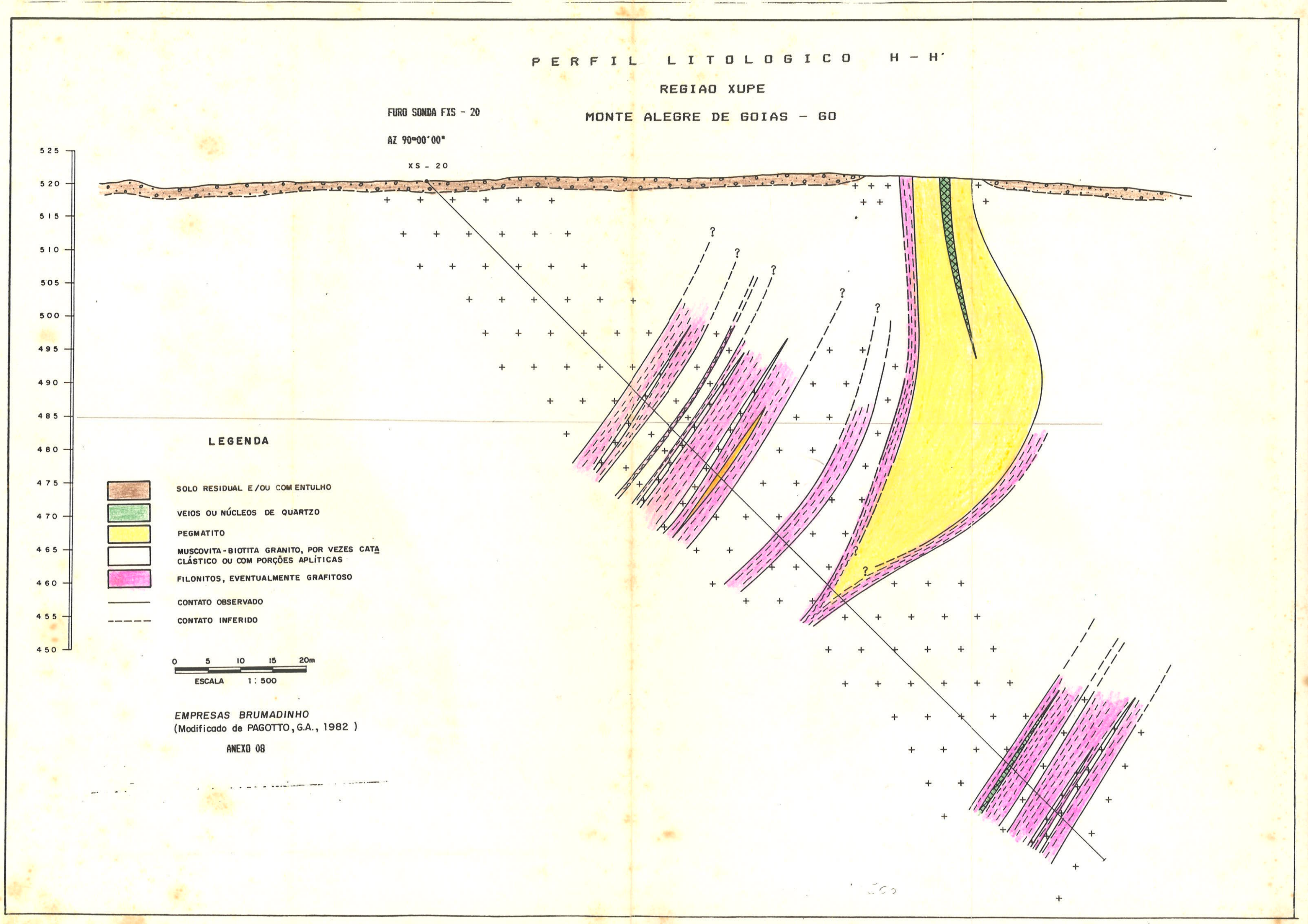




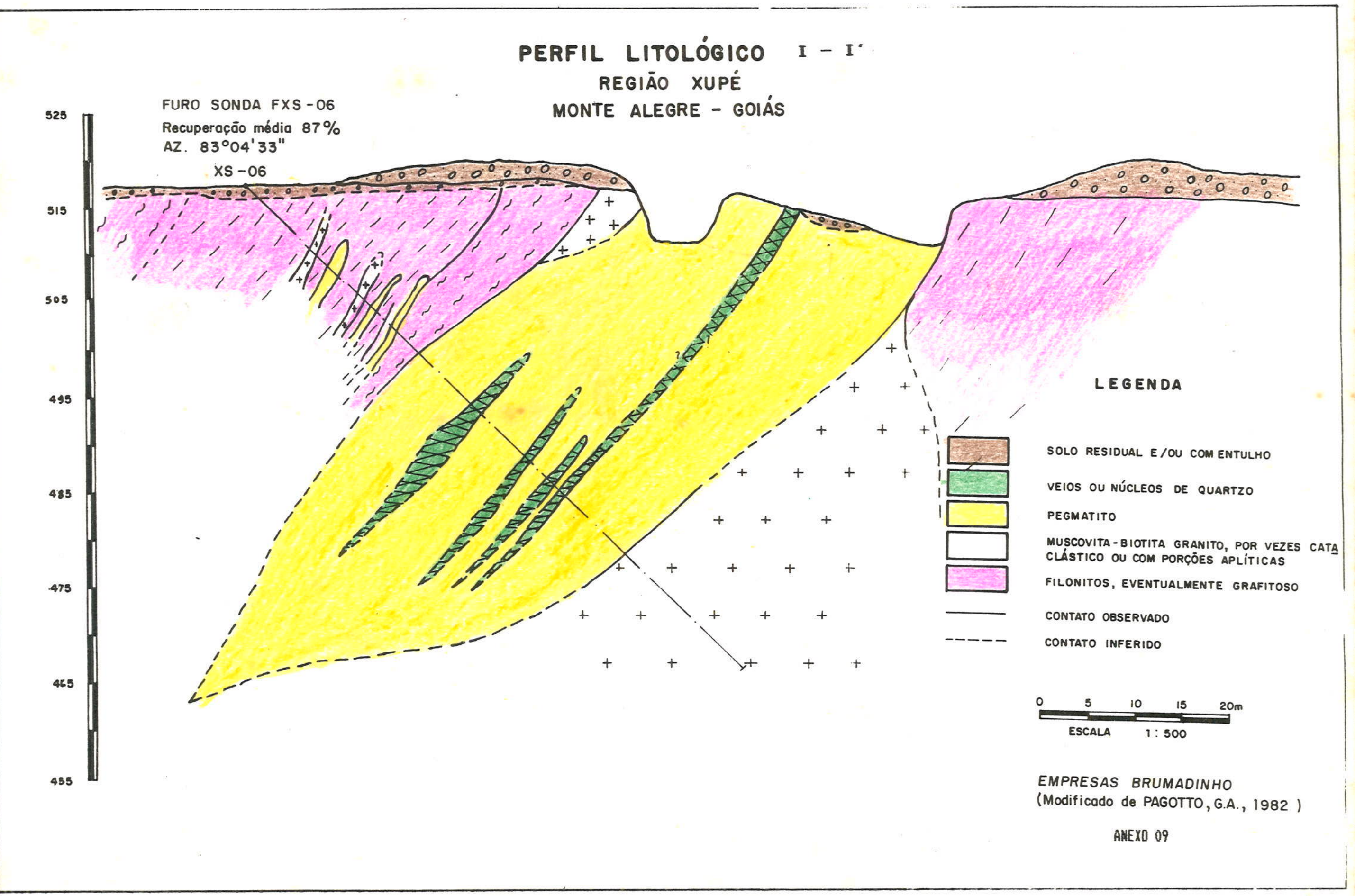




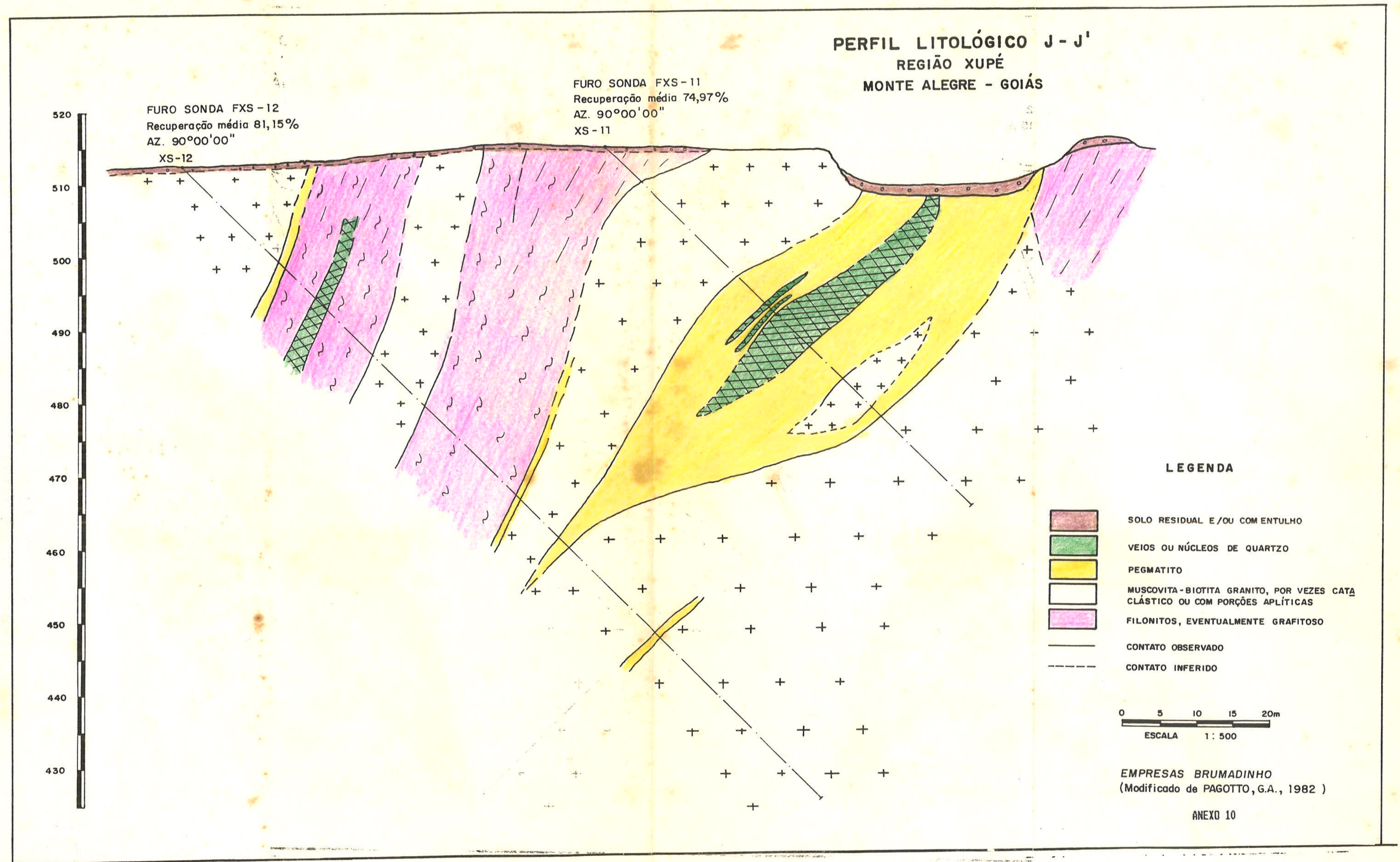




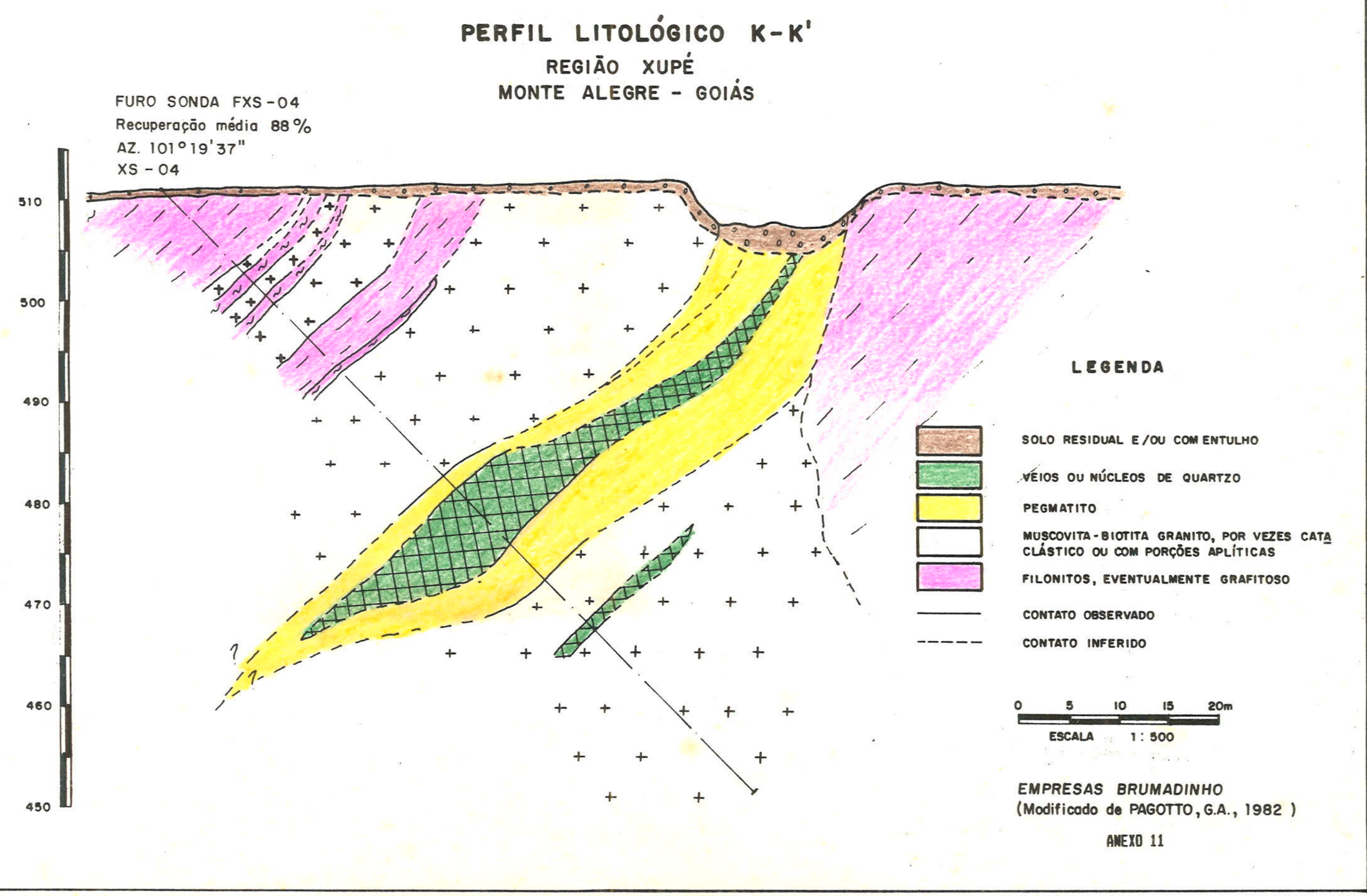




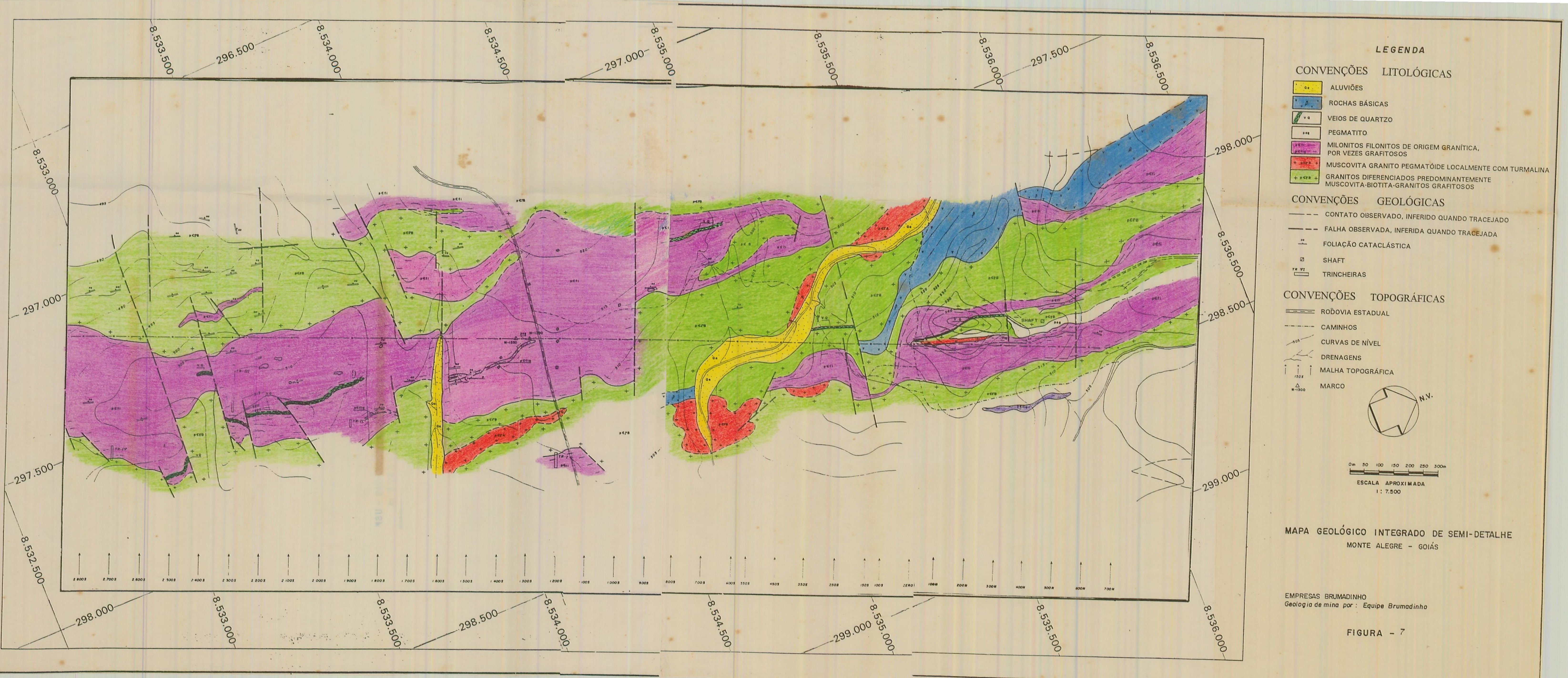



<smiles>C=CCNC(C)C</smiles> 